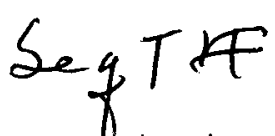

Form TI-3 $15(2-80)$

\begin{tabular}{|c|c|c|c|c|c|c|}
\hline \multirow{2}{*}{\multicolumn{2}{|c|}{ (1-3) PRIMARY Report No. $\mathrm{COO}-1545-\mathrm{TI}$}} & \multicolumn{3}{|c|}{ (5) CLASSIFICATION } & \multirow[t]{2}{*}{$\begin{array}{l}\text { (6) DATE } \\
\text { INPUT }\end{array}$} & \multirow[t]{2}{*}{$\begin{array}{l}\text { (18) DRAWER } \\
\text { NO. }\end{array}$} \\
\hline & & & CNSI & SNSI & & \\
\hline & & OUO & CFRD & SFRD & \multirow[t]{2}{*}{$\begin{array}{l}\text { DATE OF } \\
\text { REPORT }\end{array}$} & \multirow[t]{2}{*}{$\begin{array}{l}\text { (11) NO. COPIES } \\
\text { RECEIVED }\end{array}$} \\
\hline & & & CRD & SRD & & \\
\hline (7-8) CATEGORY \& 9 DISTR. CODE & \multicolumn{4}{|l|}{\begin{tabular}{l} 
(10) ANNOUNCEMENT \} \text { PRINT } $\\
{\text { \$ERA } \square \text { EPA } \square \text { PROB }}$ & $\begin{array}{l}\text { SEND TO: } \\
\text { ZTTS }\end{array}$ & \multirow[t]{2}{*}{$\begin{array}{l}\text { COVER COLOR } \\
\text { (If special) }\end{array}$} \\
\hline 24 & AHLO $\square$ GAP $\square$ ALD & & & & $\square$ INIS & \\
\hline
\end{tabular}}
\end{tabular}

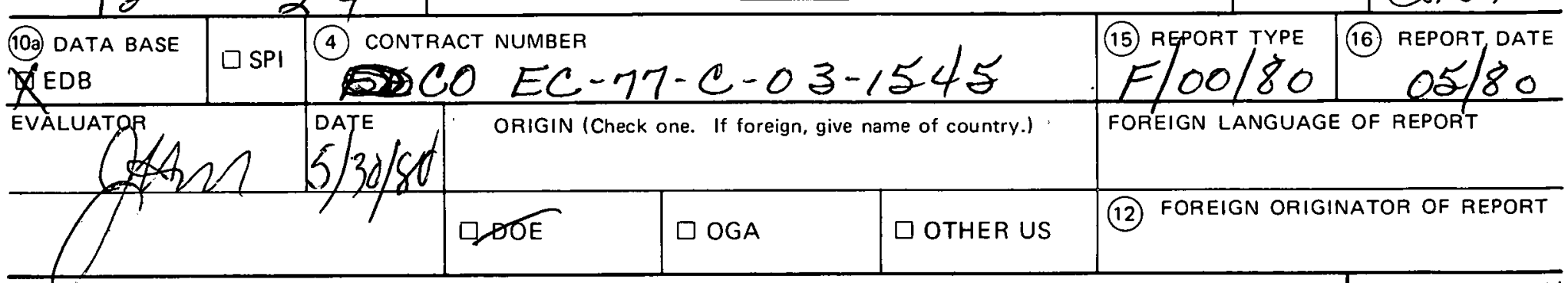

AVATLABILITY (Check. If block 1, give source of availability and price. If block 2, give CAP price.)

(13) (14) DNTIS $\square$ NTIS US Sale Only $\square$ GPO $\square$ TIC $\square$ MICRO $\square$ OTHER $\square$ NTIS MFAO1 $\square$

YUnlimited

$\square 2$ Government Agencies and Their Contractors + CAP

$\square 3$ Government Agencies and Their Contractors

$\square 4$ Export Control. Domestic Only minus Sales Outlets

$\square 5$ DOE Offices and DOE Contractors

$\square 6$ I DOE Offices Only

$\square 7$ I Participants in the

$\square 8$ I No Distribution. Refer request to

Program. Others request from

$\square$ Portions Of Document

Are Illegible
PRICE/CODE PC AOZ/MFA01

TIC COMMENTS AND DENIALS

\begin{tabular}{|c|c|c|c|c|c|c|}
\hline \multirow[t]{2}{*}{$\begin{array}{l}\text { FINISHED SIZE } \\
\text { (If special) }\end{array}$} & \multirow[t]{2}{*}{$\square 81 / 2 \times 11 ; \quad \square 8 \times 10 \% \frac{1}{2}$} & $\begin{array}{l}\square \text { APPLIED } \\
\text { TECHNOLOGY }\end{array}$ & $\begin{array}{l}\text { TECHNOLOGY } \\
\text { UTILIZATION }\end{array}$ & ABSTRA & CTOR & DATE \\
\hline & & \multicolumn{5}{|c|}{$\begin{array}{l}\square \text { CONFERENCE (COMPLETE PROCEEDINGS); } \square \text { (ABSTRACTS ONLY); } \square \text { PAPER } \\
\square \text { TRANSLATION } \square \text { THESIS } \square \text { BIBLIOGRAPHY }\end{array}$} \\
\hline \multicolumn{2}{|c|}{$\begin{array}{l}\text { PRINT DISTRIBUTION PAGE } \\
\square \text { No } \square \text { Yes }\end{array}$} & \multicolumn{5}{|c|}{ 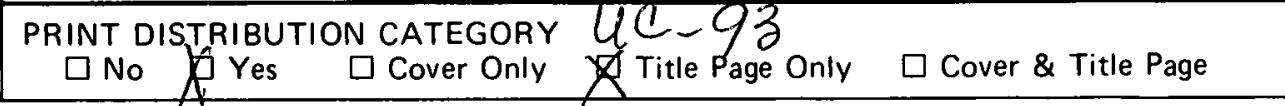 } \\
\hline \multicolumn{7}{|c|}{$\begin{array}{l}\text { RETURN REPRODUCIBLE COPY TO: } \\
\square \text { No } \quad \square \text { Originator via Distribution Section w/printed copy } \quad \square \text { Originator via Publishing Services Branch }\end{array}$} \\
\hline
\end{tabular}

DISTRIBUTION INSTRUCTIONS

MICRONEGATIVE REPRODUCTION

DENKARGED COPY

Dimicronegative $93-4$

$\square$ SEE ATTACHED SUPPLEMENT

PRINTED COPY DISTRIBUTION

Standard $4-93$

Supplementary

Total

Code A-1 Only

Code A-1 and A-2 Only

Code A-1, A-2, and A-3 + 4

$\square$ SEE ATTACHED SUPPL. PRIORITY - Distribute by:

\begin{tabular}{lcc}
\hline & STD & \\
\hline \hline WORK DONE FOR: & ERC'S & OAK RIDGE AREA \\
\cline { 2 - 3 } & $\square$ FEB $\square$ FEM & $\square$ CS $\square$ TI* \\
* Not related to other categories & $\square$ FEG $\square$ FEP & $\square$ ET $\square$ OU \\
& $\square$ FEL $\square$ & $\square$ OR* $\square$
\end{tabular}

SPECIAL NOTES/SPECIAL MARKINGS (Note and attach pertinent correspondence; instructions received via phone, verbally etc. Apply any marking and location of marking with complete text of marking pertinent to processing this report)

160

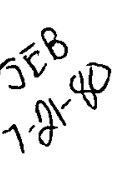

DISCLAIMER

Narraniy, express or implied, or assumes any logal liability or responsibility for the makes any completeness, or usefulness of any information, apdaratus, product, or process disclosed, or represents that its usa would not intringe privately owned rights Reference herein to any specitic commercial product, process, or service by stode name, trademark, manufacturer, or otherwise, does not necessarily constitute or imply its endorsement, recommendation, or lavoring by tha Unitod nocessorily state or reflect those of the United States Government or any agency thereot.

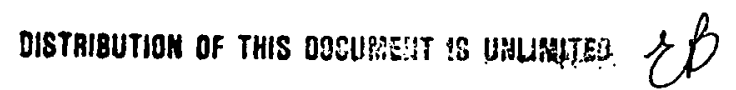

Report must be in by

ND BK

K

\begin{tabular}{cc} 
HQS \& PROGRAMS & OTHER \\
\hline$\square$ ESB $\square$ GE $\square$ OP $\square$ SE & $\square$ CF $^{*}$ \\
CO $\square$ MA $\square$ RO $\square$ & $\square$ RC \\
$\square$ FE $\square$ ESN $\square$ RL $\square$ & $\square$ OT
\end{tabular}

This book was prepared as an account of work sponsored by an agency of the United States Govet...... Stoies Government of any agency thereor. The views and opinions of authors expressed herein do no

$\$ 10.00$ 


\section{DISCLAIMER}

This report was prepared as an account of work sponsored by an agency of the United States Government. Neither the United States Government nor any agency Thereof, nor any of their employees, makes any warranty, express or implied, or assumes any legal liability or responsibility for the accuracy, completeness, or usefulness of any information, apparatus, product, or process disclosed, or represents that its use would not infringe privately owned rights. Reference herein to any specific commercial product, process, or service by trade name, trademark, manufacturer, or otherwise does not necessarily constitute or imply its endorsement, recommendation, or favoring by the United States Government or any agency thereof. The views and opinions of authors expressed herein do not necessarily state or reflect those of the United States Government or any agency thereof. 


\section{DISCLAIMER}

Portions of this document may be illegible in electronic image products. Images are produced from the best available original document. 
Forin 11. 3 2 (2) $(2-80)$

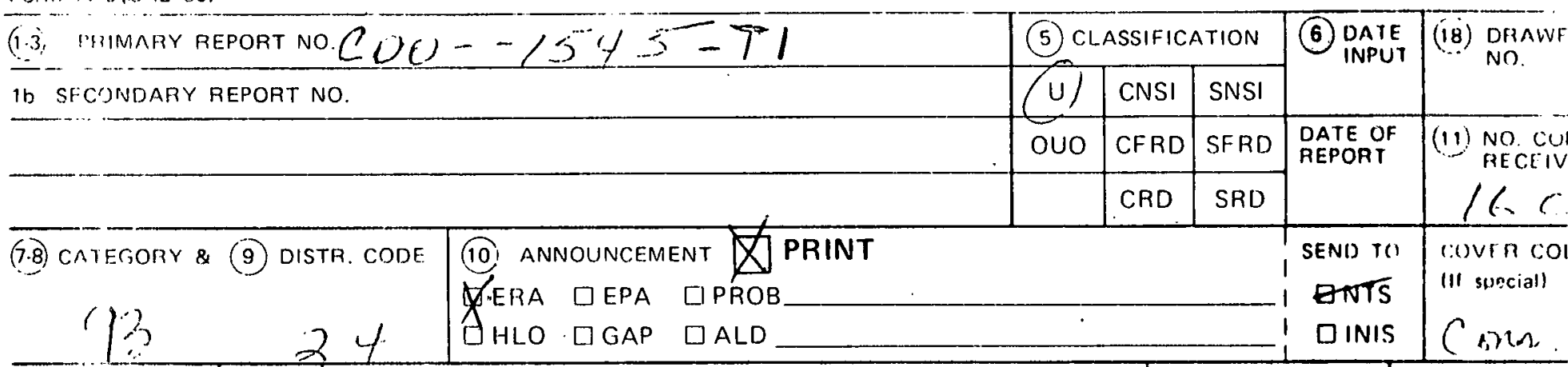

\section{\begin{tabular}{l|l|l}
\hline (10a) DA1A BASE & $\square S P I$ & (4) CONTRACT NUMBER
\end{tabular}}

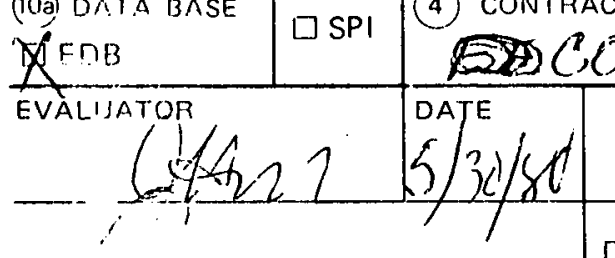

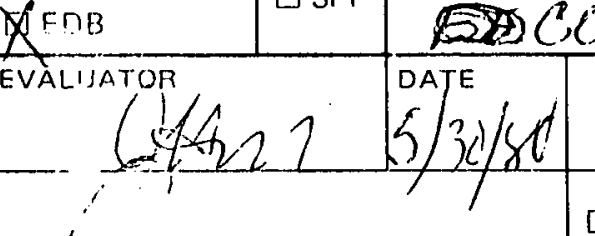

\section{पDOE} ORIGIN (Check one. If foreign, give name of country.)

(15) REPOAT TYPE

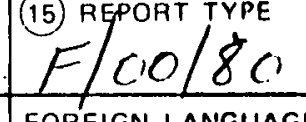

(i6) REPORT:

FOREIGN LANGUAGE OF MEPORT

AVATI ABILITY (Check. If block 1, give source of availability and price. If block 2, give CAP price.)

(13) $\int_{1} 11$ DTIIS $\square$ NTIS US Sale Only $\square$ GPO $\square$ TIC $\square$ MICRO $\square$ OTHER $\square$ NTIS MFAO1 $\square$

प1unimited

प2 Sirnernment Agencies and Their Contractors + CAP

[.] 3 Cirverment Ayencies and The" Contractors

Lla r rome Sontrol. Domestic Only mimus Sales Outlets

Lis l lien filfices and DOE Contractors

D 6 Inue Offices Only

[]] 7 l'at lirmants in the

Pronllam. Others request from $\square$ Portions Of Document
Are lllegible

(12) FOREIGN ORIGINATOR OF HEP

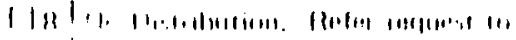

$-1$

TIC: COMMENTS AND DENIAIS

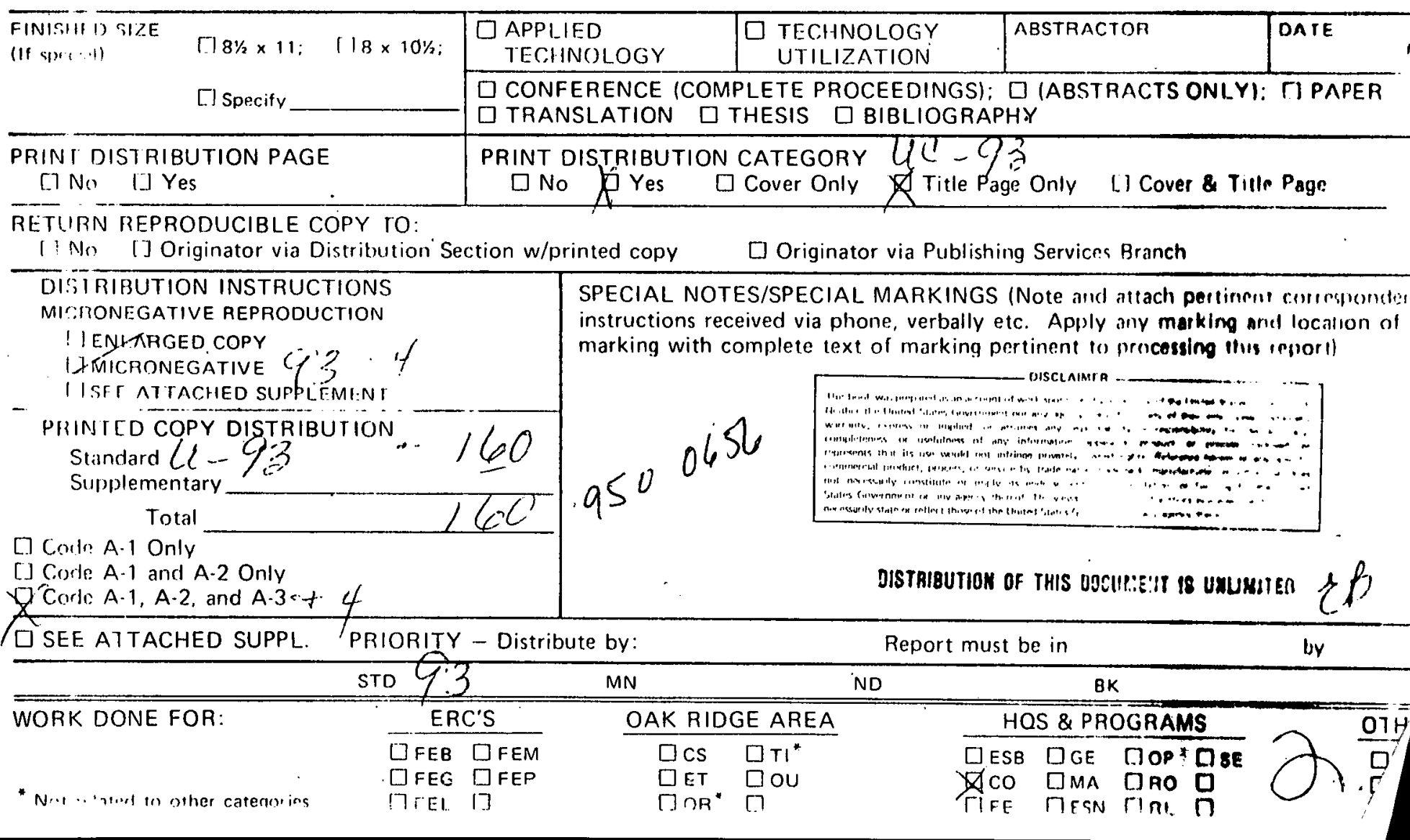




\section{DISCLAIMER}

"This book was prepared as an account of work sponsored by an agency of the United States Government. Neither the United States Government nor any agency thereof, nor any of their employees, makes any warranty, express or implied, or assumes any legal liability or responsibility for the accuracy, completeness, or usefulness of any information, apparatus, product, or process disclosed, or represents that its use would not infringe privately owned rights. Reference herein to any specific commercial product, process, or service by trade name, trademark, manufacturer, or otherwise, does not necessarily constitute or imply its endorsement, recommendation, or favoring by the United States Government or any agency thereof. The views and opinions of authors expressed herein do not necessarily state or reflect those of the United States Government or any agency thereof."

This report has been reproduced directly from the best available copy.

Available from the National Technical Information Service, U.S. Department of Commerce, Springfield, Virginia 22161.

Price: Paper Copy $\$ 10.00$

Microfiche $\$ 3.50$ 


\title{
HANDBOOK OF FUEL CELL PERFORMANCE
}

\author{
Prepared by \\ Thomas G: Benjamin \\ Supervisor \\ Fuel Cell Engineering \\ Elias H. Camara \\ Assistant Director \\ Energy Conversion \\ Systems and Engineering \\ Leonard G. Marianowski \\ Associate Director \\ Energy Conversion \\ and Storage Research \\ Institute of Gas Technology \\ IIT Center, 3424 S. State Street \\ Chicago, Illinois 60616
}

Project 61012

Date Published - May 1980

Prepared for the

UNITED STATES DEPARTMENT OF ENERGY

Under Contract No. EC-77-C-03-1546 


\section{ACKNOWLEDGMENT}

The authors wish to thank Martin Zlotnick, Project Officer, Fuel Cells, and John E. Young, Technical Manager, Fuels Utilization, of the U.S. Department of Energy for the opportunity to develop this handbook.

This undertaking would have been impossible without the cooperation of the entire fuel cell community. In particular, the following people contributed to our efforts, either by supplying literature and data or by offering their reviews and comments: John Appleby and Arnold P. Fickett of EPRI; William E. Houghtby of United Technologies Corp.: Stanley S. Kurpit and Walter G. Taschek of the U.S. Army Mobility Equipment Research and Development Command; and Hansraj C. Maru of Energy Research Corp.

The authors are grateful to Keith F. Blurton, Director, Energy Conversion and Storage Research, Institute of Gas Technology, for his valuable suggestions concerning the content of and approach to this handbook.

Our discussions about IGT data with Dr. K. W. Hahn, G. A. Jarvi, D. R. Vasil, and others directly contributed to the insight required to accomplish this task. We also appreciate the work of the IGT Graphics Department, the typing efforts of Brenda Jordan and Harriet Heidelmeier, and the editing efforts of Marita Moniger and Kathy O'Connell.

The format and approach used in developing the handbook can be largely credited to Edward A. Gillis, Project Manager, Fuel Cell Systems. EPRI. We feel that his interested, enthusiastic, and enlightening involvement has enhanced the application and usefulness of the handbook. Special thanks are extended to him. 
SCOPE

CHAPTER 1. INTRODUCTION TO FUEL CELLS

Definition

Advantages

Environmental Acceptability

Flexibility

Efficiency

Fuel Cell Efficiency

Fuel Cell System

Types of Fuel Cells

Solid Oxide Fuel Cells

Molten Carbonate Fuel Cells $r$

Acid Fuel Cells 11

Alkaline Fuel Cells 11

Basic Principles of Operation . . 12

General $\quad \cdot 12$

Phosphoric Acid 13

Molten Carbonate . . 13

References Cited $\quad 14$

CHAPTER 2. ELEMENTARY ELECTROCHEMISTRY AND FUEL CELL $\begin{array}{ll}\text { OPERATING PARAMETERS } & 15\end{array}$

$\begin{array}{ll}\text { Introduction. } & 15\end{array}$

$\begin{array}{lr}\text { Reversible (Equilibrium) Electrodes } & 15\end{array}$

$\begin{array}{ll}\text { The Nernst Equation } & 15\end{array}$

$\begin{array}{ll}\text { Exchange Current } & 17\end{array}$

$\begin{array}{lll}\text { Non-Equilibrium Electrodes - Polarization } & \cdots & 17\end{array}$

Activation Polarization - Tafel Equation 17

Concentration Polarization - The Limiting Current 18

Total Electrode Polarization $\quad 19$

Ohmic Polarization - IR Losses 19

Cell Performance $\quad 19$

$\begin{array}{ll}\text { Fuel Cell Operating Variables } & 20\end{array}$

Temperature 20

Pressure $\quad 21$

Utilization $\quad 21$

Reactant Gas Composition $\quad 21$

Impurities $\quad 21$

References Cited $\quad 23$ 
TABLE OF CONTENTS, Cont.

CHAPTER 3. PHOSPHORIC ACID FUEL CELLS

Introduction

Basic Concepts and Cell Components $\quad 30$

Phosphoric Acid Fuel Cell Performance $\quad 31$

General Considerations $\quad 31$

Design Considerations 31

Effect of Temperature $\quad 33$

Effect of Pressure

Effect of Reactant Concentration and Utilization 37

Oxidant $\quad 37$

Fuel $\quad 37$

Effect of Impurities

Carbon Compounds $\quad 39$

Sulfur Compounds $\quad 40$

Nitrogen Compounds $\quad 41$

Summary, Other Compounds. 42

Effect of Internal Resistance $\quad 45$

Sample Calculations $\quad 45$

Pressure - . 46

Temperature $\quad \cdot \quad 46$

Oxidant $\quad 47$

Fuel $\quad 47$

$\begin{array}{ll}\text { Design Considerations } & 48\end{array}$

$\begin{array}{lll}\text { References Cited } & \text {. } & 49\end{array}$

CHAPTER 4. MOLTEN CARBONATE FUĒL CELLS 53

Introduction $\quad$. 53

Basic Concepts and Cell Components $\quad 55$

Molten Carbonate Fuel Cell Performance $\quad 57$

General Considerations $\quad 57$

Design Considerations $\quad 58$

Effect of Temperature $\quad 59$

Effect of Pressure $\quad 61$

Effect of Reactant Concentration and Utilization $\quad 63$

Oxidant 63

Fuel $\quad 66$

$\begin{array}{ll}\text { Effect of Impurities } & 67\end{array}$

Carbon $\quad 67$

Sulfur $\quad 67$

Nitrogen $\quad 68$

$\begin{array}{ll}\text { Chlorine } & 68\end{array}$

Summary, Other Compounds 68

Effect of Internal Resistance $\quad 69$

vi

$\begin{array}{llllllllllllllllllllll}\text { I N S T I T U T E } & \text { O F F } & \text { G A S } & \text { T E } & \text { C H N } & \text { O } & L & \text { O } & G & Y\end{array}$ 
TABLE OF CONTENTS, Cont.

Sample Calculations $\quad 69$

Temperature $\quad 69$

Fuel $\quad 71$

$\begin{array}{ll}\text { Oxidant } & 75\end{array}$

$\begin{array}{ll}\text { Pressure } & 76\end{array}$

Design Considerations $\quad 76$

$\begin{array}{ll}\text { References Cited } & 77\end{array}$

CHAPTER 5. FUEL CELL EFFICIENCY AND HEAT BALANCE

Introduction $\quad, \quad 79$

Fuel Cell Efficiency $\quad 79$

Thermodynamic Efficiency 79

Voltage Efficiency $\quad 82$

Current Efficiency $\quad 82$

Electrochemical Efficiency $\quad 82$

Heating Value Efficiency

Fuel Cell Efficiency $\quad 84$

Sample Calculations $\quad 85$

Phosphoric Acid Fuel Cell . , 85

Molten Carbonate Fuel Cell

Experimental Fuel Cell Efficiencies 90

Phosphoric Acid 90

Molten Carbonate $\quad 90$

Fuel Cell Heat Balance 93

References Cited $\quad 96$

CHAPTER 6. FUEL CELL SYSTEM EFFICIENCY 97

Fuel Cell System Efficiency 97

System Examples $\quad 98$

Air-Blown Coal Gasifier/Molten Carbonate Fuel Ce11/
Bottoming Cycle

Oxygen-Blown Coal Gasifier/Molten Carbonate Fuel Cell/
Bottoming Cycle

Mothanol Reformer/Phosphoric Acid Fuel Cell/Export Steam 104

No. 2 Fuel Oil Processing/Phosphoric Acid Fuel Cell/ 106

$\begin{array}{ll}\text { Export Steam } & 108 \\ \text { Naphtha Reformer/Phosphoric Acid Fuel Cell } & 106\end{array}$

References Cited $\quad 110$

APPENDIX A. HEATING VALUES OF POTENTIAL FUEL CELL SYSTEM FUELS 111

APPENDIX B. CONVERSION FACTORS AND FUEL CELL CONSTANTS 121

$\begin{array}{ll}\text { APPENDIX C. . LIST OF SYMBOLS } & 125\end{array}$

vii

I N S T I T U T E 


\section{LIST OF FIGURES}

Figure No.

$\underline{\text { Päge }}$

1.1

Complete Fuel Cell Power Plant

4

1.2

Comparison of Power System Emissions

4

1.3

Power System Efficiency Comparison as a

1.4

Comparison of Power System Efficiencies

1.5 Preliminary Fuel Utilization Characteristics

for a Fuel Cell Power Plant

1.6

Fue1 Cell Types

1.7a Conceptual Diagram of a Phosphoric Acid Fuel

2.1 Schematic Fuel Cell Polarization Curve

3.1 Phosphoric Acid Fuel Cell Polarization Curves

$3.2 \quad 1.5-\mathrm{kW}$ Indirect Methanol-Air Phosphoric Acld

3.3 Energy Research Corporation's Phosphoric Acid

Fuel Cell Components and Stack

3.4 United Technologies' 40-kW Phosphoric Acid

3.5 United Technologies' 1.0-MW Phosphoric Acid Fuel Cell Pilot Power Plant

3.6a United Technologies' 4.8-MW Phosphoric Acid

Fuel Cell Power Plant Demonstrator (Fuel

Cell d-c Module)

United Technologies' 4.8-MW Phosphoric Acld Fue1 Cell Power Plant Demonstrator (Power Plant: Artist's Conception) 
Figure No.

Page

3.9

Baseline Phosphoric Acid Fuel Cell Performance

at $175^{\circ} \mathrm{C}, \mathrm{I} \mathrm{atm}, \mathrm{H}_{2}$ Fuel, $\mathrm{O}_{2}$ Oxidant, Low

Utilization

Effects of Temperature on Phosphoric Acid Fuel

Cell Performance at $50 \mathrm{psia}, 300 \mathrm{ASF}, 190^{\circ} \mathrm{F}$

Anode Dewpoint

Effects of Temperature on Phosophoric Acid Fuel

Cell Anode CO Tolerance

Cell Voltage Gain at a Fixed Current Density as

a Function of Cell Operating Pressure

Effect of Pressure on Cell Voltage at $375^{\circ} \mathrm{F}$,

3.15 Effect of CO Content and Temperature on Anode

Performance, $0.35 \mathrm{mg} \mathrm{Pt} / \mathrm{cm}^{2}, 269 \mathrm{~mA} / \mathrm{cm}^{2}$

Effects of Oxygen Partial Pressure on Cathode

3.16 Effect of Temperature on Slope of Performance

3.17 Effect of $\mathrm{H}_{2} \mathrm{~S}$ on Phosphoric Acid Fuel Cell Performance

3.18 Performance Loss Due to Ammoniation of $\mathrm{H}_{3} \mathrm{PO}_{4}$

3.19 Relative Cathode Catalyst Activity as a

Function of Percent $\mathrm{H}_{3} \mathrm{PO}_{4}$ Conversion to $\left(\mathrm{NH}_{4}\right) \mathrm{H}_{2} \mathrm{PO}_{4}$

Cell Endurance in the Presence of Ammonia

4.1 Molten Carbonate Performance History at 
Fuel at 25\% Utilization

4.4 Effect of Temperature on Cel1, Anode, and Cathode Performance at $1 \mathrm{~atm}, 650^{\circ} \mathrm{C}$, $200 \mathrm{~mA} / \mathrm{cm}^{2}$, and Low Utilizations

Effect of Temperature on Molten Carbonate

Fuel Cell Performance at $1 \mathrm{~atm}, 200 \mathrm{~mA} / \mathrm{cm}^{2}$, 70 mol \% Air $30 /$ mol \% $\mathrm{CO}_{2}$ Oxidant at $50 \%$ Utilization, $75 \%$ Fuel Utilization

4.6 Effect of Pressure on Molten Carbonate

Fuel Cell Performance at $650^{\circ} \mathrm{C}, 160 \mathrm{~mA} / \mathrm{cm}^{2}$, $70 \mathrm{~mol} \%$ Air $30 / \mathrm{mol} \% \mathrm{CO}_{2}$ Oxidant at $50 \%$ Utilization, $75 \%$ Fuel Utilization

4.7 Effect of Reactant Utilization on Molten Carbonate Fuel Cel1 Performance at $1 \mathrm{~atm}$, $650^{\circ} \mathrm{C}, 160 \mathrm{~mA} / \mathrm{cm}^{2}, 70 \mathrm{~mol} \% \mathrm{Air} /$

30 mol \% $\mathrm{CO}_{2}$ Oxidant, Simulated Reformed Methane Fuel

4.8 Effect of Oxidant Partial Pressure on Molten Carbonate Fuel Cell Performance at 1 atm Total Pressure, $650^{\circ} \mathrm{C}, 160 \mathrm{~mA} / \mathrm{cm}^{2}$

4.9 Effect of Fuel Partial Pressure on

Molten Carbonate Fuel Cell Performance

at 1 atm Total Pressure, $650^{\circ} \mathrm{C}, 160 \mathrm{~mA} / \mathrm{cm}^{2}$

5.1 Fuel Cell Heat Balance

6.1 Complete Fuel Cell Power Plant

6.2a Air-Blown Coa1 Gasifier/Molten Carbonate Fuel Cell/Bottoming Cycle - Flow Schematic

6.23 Air-Blown Coal Gasifier/Molten Carbonate 


\section{Figure No.}

$$
6.4
$$

6.5

6.6

$A-1$
Methanol Reformer/Phosphoric Acid Fuel

Cel1 System With Export Steam

No. 2 Fuel 0il Processing/Phosphoric Ac1d Fuel Ce1l/Export Steam

Naptha Steam Reformer/Phosphoric Acid Fuel Cell - Flow Schematic

Mean Heat Capacities of Gases in the

Ideal-Gas State (Base Temperature, $77^{\circ} \mathrm{F}$ ) $\underline{\text { Page }}$

104

106

107

118

xii 
Fuel Gas Dew Point for Data in Figure 4.6

5.2 Fuel Gas Composition and Thermodynamic Values for Phosphoric Acid Fuel Cell Sample Efficiency Calculation, 1 atm, $190^{\circ} \mathrm{C}$ 
Values for Molten Carbonate Fuel Cell

Sample Efficiency Calculation, 1 atm, $650^{\circ} \mathrm{C}$

5.4 Summary of Phosphoric Acid Fuel Cell

A-3 Composition and Higher Heating Value of 
LIST OF TABLES, Cont.

Table No.

Page

B-1

Value of Universal Gas Constant $R$ in

123

Various Units

B-2

Value of Faraday's Constant $F$ in Various Units

B-3

Miscellaneous Conversion Factors

B-4

Energy Unit Conversion Chart

124 
A fuel cell power plant system consists of a fuel processor that produces $\mathrm{H}_{2}$-rich fuel cell feed's from raw and primary fuels, a power section that converts the chemical energy in the gaseous feeds to $d-c$ power, and a power conditioner that converts $d-c$ to $a-c$ power. The relationships between the $d-c$ power provided by the cell and the power conditioner are well defined. But the interrelationships between the fuel processor and the power section are complex and have not been well documented. This is especially important in light of the growing number of fuel processing engineers entering the fuel cell power plant field and the growing interest in advanced fuel processing concepts such as coal conversion and autothermal reforming. The intent of this document is to provide a description of fuel cells, their performances and operating conditions, and the relationship between fuel processors and fuel cells. This information will enable fuel cell engineers to know which fuel processing schemes are most compatible with which fuel cells and to predict the performance of a fuel cell integrated with any fuel processor.

The data and estimates presented here are for the phosphoric acid and molten carbonate fuel cells because they are closer to commercialization than other types of fuel cells. Performance of the cells is shown as a function of operating temperature, pressure, fuel conversion (utilization), and oxidant utilization. The effect of oxidant composition (for example, air versus $\mathrm{O}_{2}$ ) as well as fuel composition is examined because fuels provided by some of the more advanced fuel processing schemes such as coal conversion will contain varying amounts of $\mathrm{H}_{2}, \mathrm{CO}, \mathrm{CO}_{2}, \mathrm{CH}_{4}, \mathrm{H}_{2} \mathrm{O}$, and sulfur and nitrogen compounds.

Chapter 1 includes a brief description of fuel cells and their application to industrial, commercial, and residential power generation. Chapter 2 includes development of the background necessary to understand the electrochemical aspects of fuel cells. The phosphoric acid fuel cell is discussed in Chapter 3, including how it is affected by operating conditions. Chapter 4 covers the molten carbonate fuel cell. The equations developed in Chapters 3 and 4 will help systems engineers to evaluate the application of the phosphoric acid and molten carbonate fuel cells to commercial, utility, and industrial power generation and waste heat utilization. The document concludes with Chapter 5, a detailed discussion of fuel cell efficiency, with examples, and Chapter 6, a sampling of fuel cell systems.

I N S T I T U TE O O F O G A S T T C H N O L O G Y


A comprehensive listing of fuel cell related publications since the mid-1960's is contained in "Fuel Cells: A Bibliography," Technical Information Center Report TID-3359, June 1977. 
CHAPTER 1. INTRODUCTION TO FUEL CELLS

Definition

Fuel cells are electrochemical energy conversion devices, defined as electrochemical cells that can continuously transform the chemical energy of a fuel and oxidant to electrical energy by an isothermal process involving an essentially invariant electrode-electrolyte system. Unlike a battery, a fuel cell does not run down or require recharging; it will operate as long as both fuel ( $\mathrm{H}_{2}$ from a hydrocarbon fuel such as coal, oil, or gas) and an oxidant $\left(\mathrm{O}_{2}\right.$ from air) are supplied to the electrodes. The electrodes act as reaction sites or catalysts where the electrochemical transformation of the fuel and oxidant occurs, producing $d-c$ power. This electrochemical transformation is isothermal; that is, the fuel cell directly uses the available free energy in the fuel at its operating temperature. Thus, it is not Carnot-cycle limited and can yield a high fuel to d-c power conversion efficiency.

For a fuel cell power plant to be a useful contributor to an energy generation scheme, it must be able to use commercially available fuels and be able to produce a-c electrical power. Thus, a fuel cell generator system has three components, which are shown schematically in Figure 1.1. The fuel processor converts a hydrocarbon fuel to a hydrogen-rich gas that is fed to the fuel cell stacks to produce $d-c$ power. The power conditioner or inverter transforms the $d-c$ power to a-c power compatible with user requirements. The concept of the fuel cell system will be further developed in a later section.

\section{$\underline{\text { Advantages }}$}

Environmental Acceptability. The fuel cell is quiet because it has no moving parts. Because the fuel cell is not a combustion device, emissions such as $\mathrm{NO}_{\mathrm{x}}, \mathrm{CO}$, and unburned hydrocarbons are not a serious problem. $\mathrm{SO}_{\mathrm{x}}$ emissions are not a problem because the sulfur content of the fuel stream to the power plant must be reduced to attain long fuel cell life. Such low levels of emissions (Figure 1.2), coupled with the fuel cell's quiet, waterconserving operation, result in environmental acceptability and siting flexibility. 


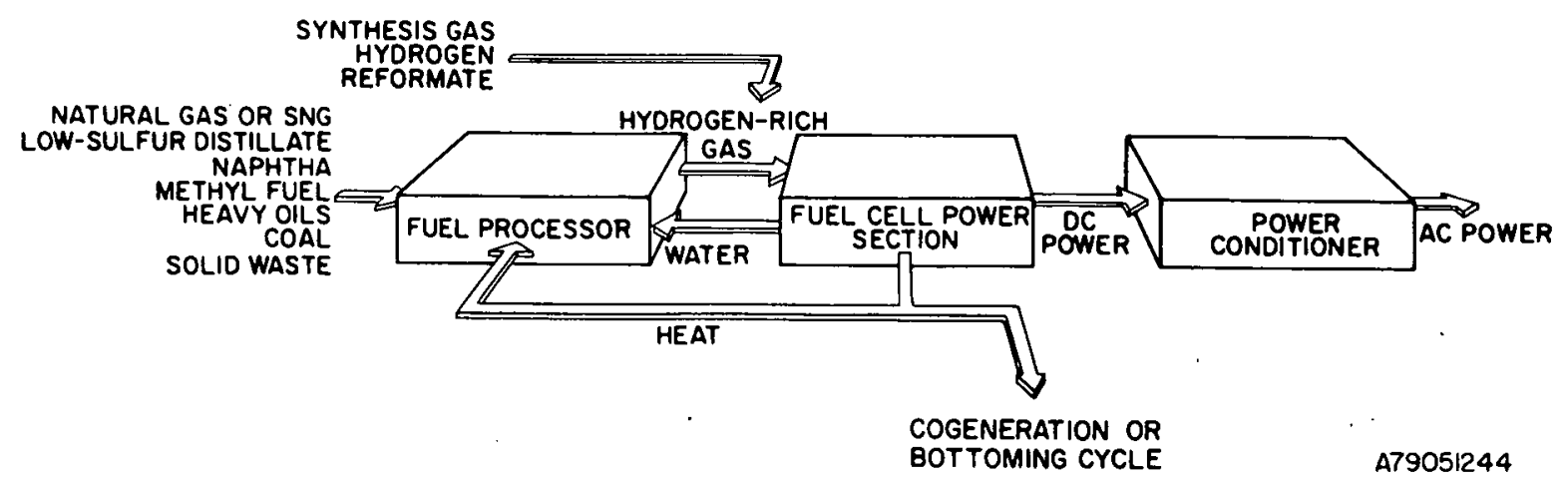

Figure 1.1. COMPLETE FUEL CELL POWER PLANT ${ }^{1}$

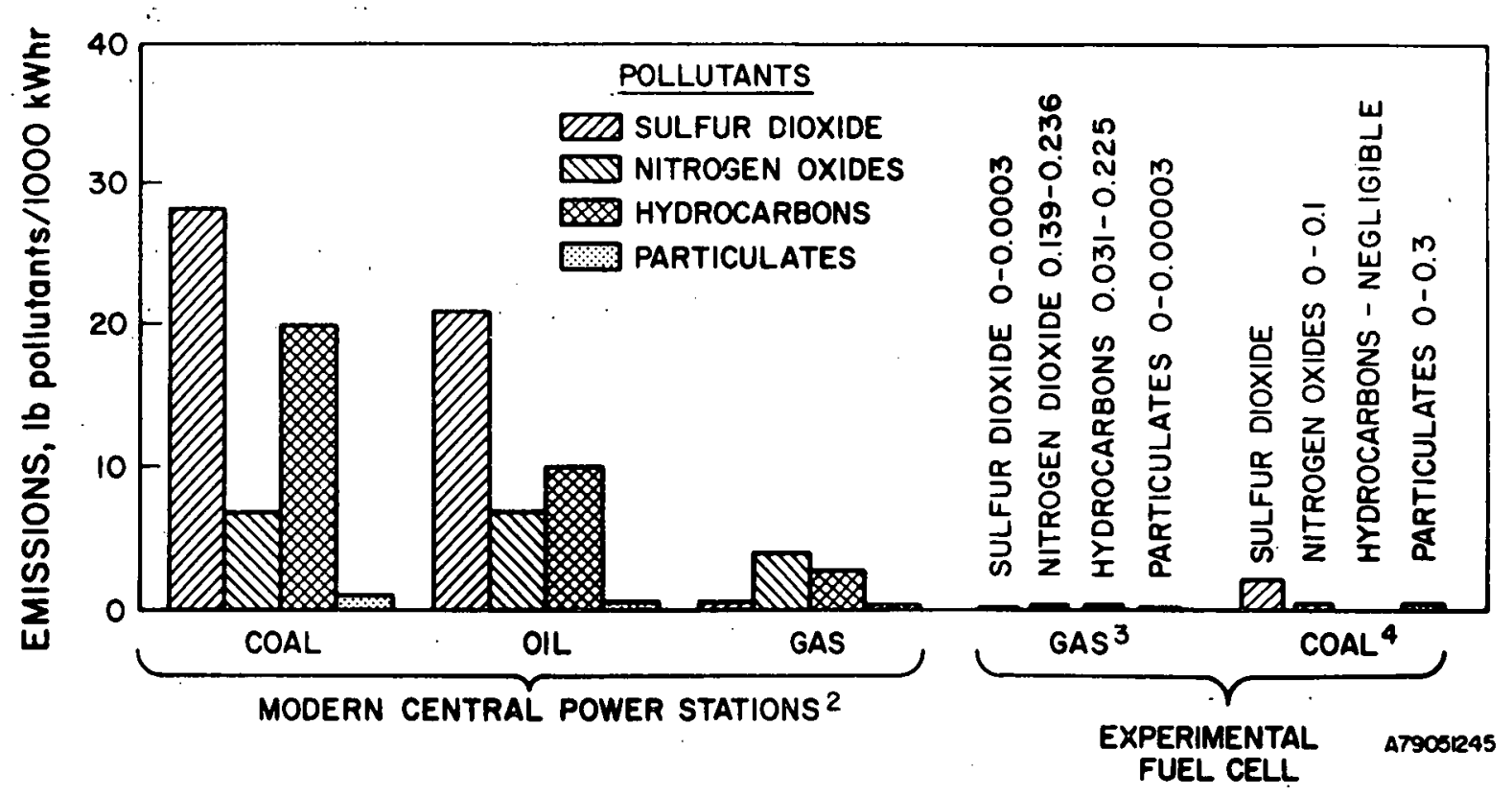

Figure 1.2. COMPARISON OF POWER SYSTEM EMISSIONS

Flexibility. A single fuel cell normally generates power at approximately 0.5 to 1 volt and can be connected in serles stacked with other cells to obtain almost any desired voltage. The current produced is a function of the size (the area) of a single cell. The range of sizes, the modularity, and the loadfollowing capabilities make the fuel cell system an attractive candidate for power generation in a variety of applications, including on-site and central plants for commercial, industrial, and residential uses. With modular design, 
fuel cell efficiency is independent of size; small units can operate as efficiently as large ones (Figure 1.3). Efficiency is relatively constant over a wide range of load (Figure 1.4).

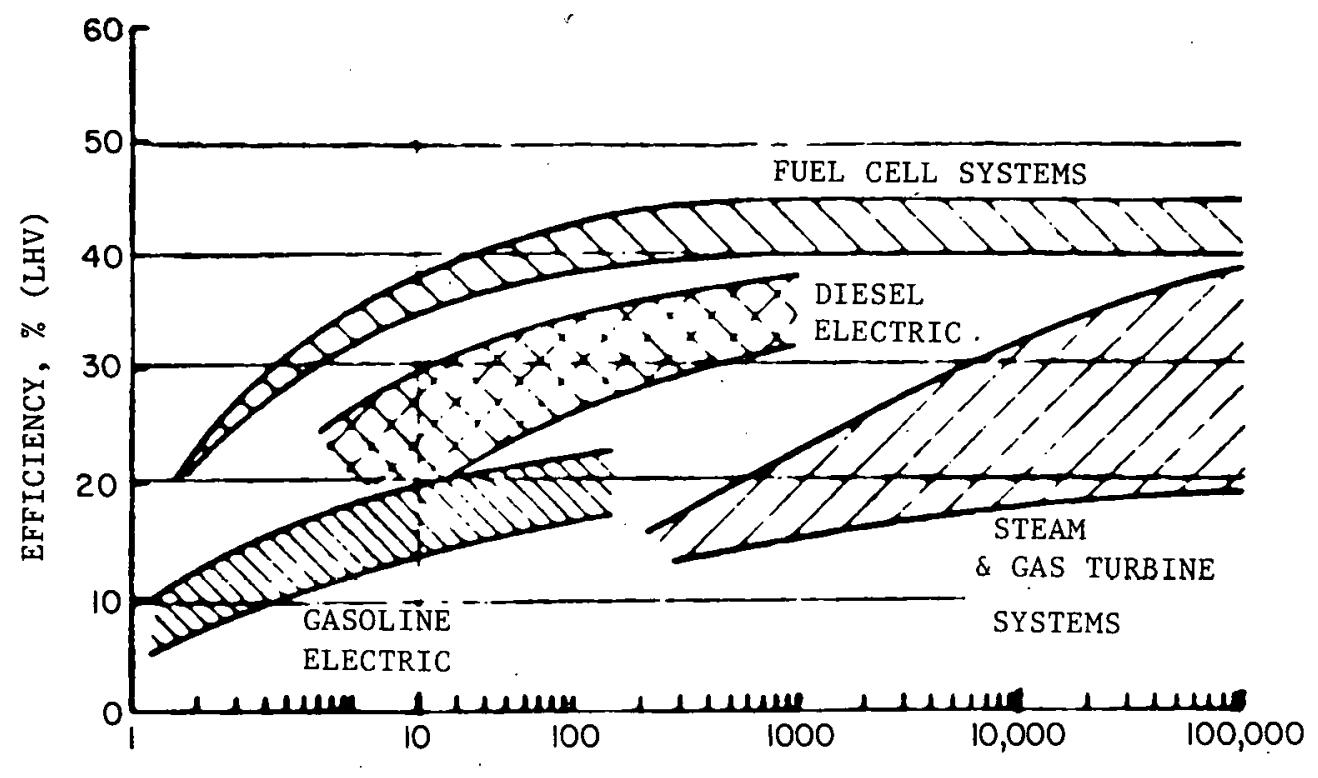

POWER OUTPUT, $\mathrm{kW}$

A80010202

Figure 1.3.. POWER SYSTEM EFFICIENCY COMPARISON AS A FUNCTION OF SIZE $^{5}$

Efficiency. Fuel cells are inherently more efficient than conventional. power generation devices because they do not suffer from the Carnot limitation, as discussed in the next section.

\section{Fue1 Cell Efficiency}

Chapters 2 and 5 will discuss fuel cell efficiency and factors affecting the efficiency in detail. However, it is important to mention the theoretical efficiency of fuel cells here. The following includes a comparison of maximum fuel cell efficiency with conventional power generation techniques to illustrate the basic attractiveness of fuel cells.

The process of galvanic oxidation that produces electricity in a fuel cell resembles that of a conventional storage battery. The fuel cell does not store electrical energy; instead, it combines electrochemical oxidation (a property

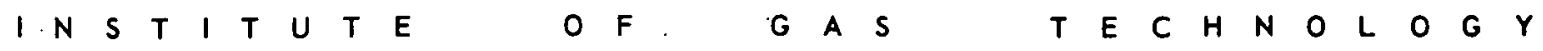




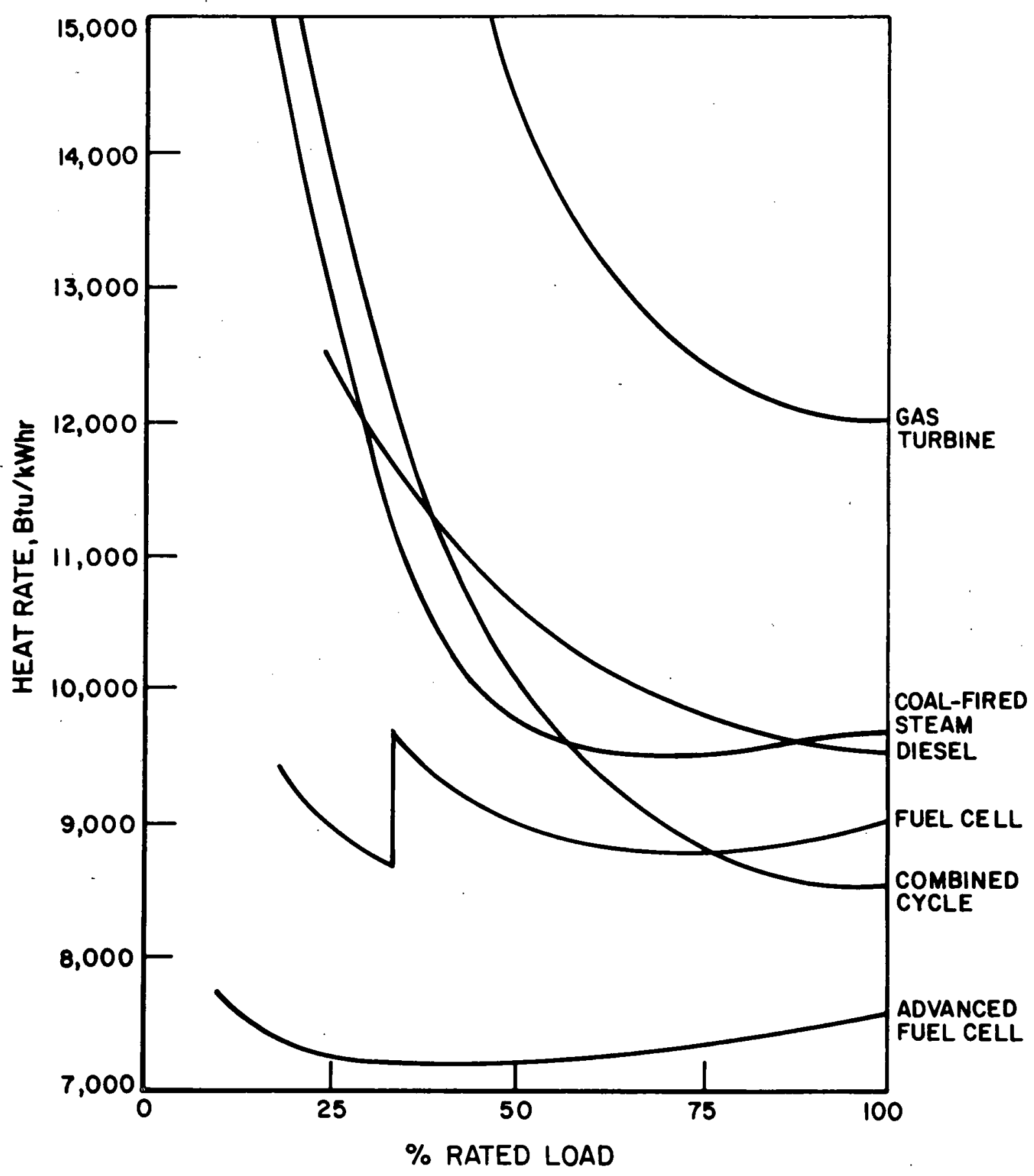

479061305

Figure 1.4. COMPARISON OF POWER SYSTEM EFFICIENCIES ${ }^{6}$

(From "Fuel-Cell Power Plants" by A. P. Fickett.

Copyright December, 1978, by Scientific American, Inc. All rights reserved.) 
of the storage battery) with continuous feeding of sufficient fuel (a feature of the mechanical engine) to maintain a desired output.

The efficiency, $\varepsilon$, of steam or internal combustion engines, two of the most widely usèd conventional methods of generating electricity, is limited by the temperatures at which heat is supplied $\left(\mathrm{T}_{2 \mathrm{C}}\right)$ and rejected $\left(\mathrm{T}_{1 \mathrm{C}}\right)$, according to the Carnot cycle -

$$
\varepsilon=\frac{\mathrm{T}_{2 \mathrm{C}}-\mathrm{T}_{1 \mathrm{C}}}{\mathrm{T}_{2 \mathrm{C}}}
$$

The maximum practical theoretical efficiency for heat engines is $40 \%$ to $50 \%$. Fuel cells convert energy isothermally (not Carnot-cycle limited), and most of the chemical energy of the fuel may be converted to electricity.

For example, in a hydrogen/oxygen fuel cell, the following reactions occur :

$$
\begin{array}{ll}
\text { Anode Reaction } & \mathrm{H}_{2} \rightarrow 2 \mathrm{H}^{+}+2 \mathrm{e}^{-} \\
\text {Cathode Reaction } & 2 \mathrm{e}^{-}+1 / 2 \mathrm{O}_{2}+2 \mathrm{H}^{+}+\mathrm{H}_{2} \mathrm{O}(\mathrm{g}) \\
\text { Overall Reaction } & \mathrm{H}_{2}+1 / 2 \mathrm{O}_{2} \rightarrow \mathrm{H}_{2} \mathrm{O}(\mathrm{g})
\end{array}
$$

For the overall reaction at $298^{\circ} \mathrm{K}$, based on lower heating values (LHV),

$$
\begin{aligned}
\Delta \mathrm{G} & =-54.6 \mathrm{kcal} / \mathrm{g}-\mathrm{mol} \\
\Delta \mathrm{H} & =-57.8 \mathrm{kcal} / \mathrm{g}-\mathrm{mol}
\end{aligned}
$$

The maximum amount of heat energy that can be produced isothermally and isostatically by the overall reaction is the enthalpy change, $\Delta \mathrm{H}$, but the fuel cell can only convert to electricity an amount equivalent to the Gibbs free energy, $\Delta G$. The difference, $T \Delta S=\Delta H-\Delta G$, is the minimum amount of heat that is produced in an isothermal, isostatic process. Therefore, the maximum efficiency of a hydrogen/oxygen fuel cell at $298^{\circ} \mathrm{K}$ is ${ }^{*}-$

$$
\varepsilon_{\max }=\left(\frac{\Delta \mathrm{G}}{\Delta \mathrm{H}}\right)(100)=\left(\frac{-54.6}{-57.8}\right)(100)=94.5 \%
$$

The standard potential of a fuel cell, $\mathrm{E}^{\mathrm{O}}$, is directly related to the standard free-energy change for the overall reaction, according to the expression -

$\because$ This quantity is often based on higher heating values. Then $\varepsilon_{\max }=83 \%$. 


$$
\Delta G^{\circ}=-n F E^{\circ}
$$

where $\mathrm{n}$ is the number of electrons transferred, or g-equiv/g-mol, and $\mathrm{F}$ is the Faraday constant, which is equal to $23.06 \mathrm{kcal} / \mathrm{V} \cdot \mathrm{g}$-equiv.

In a fuel cell, all the free energy, $\Delta G$, of the reaction is available as cell electromotive force (emf) and a large fraction of the $T \Delta S$ heat can be recovered in a bottoming cycle or cogeneration scheme. In contrast, in any heat engine a smaller fraction of the $\Delta \mathrm{H}$ of the combustion reaction is available for useful work as a result of the Carnot efficiency limitation.

\section{Fuel Cell System}

The fuel cell system consists of a fuel processor, a fuel cell, a power conditioner, and optional cogeneration or bottoming cycle schemes, depending on application. A hydrocarbon fuel (natural gas, mined coal, solid waste, refined petroleum products or resids, synthetic natural gas, naphtha, methanol, etc.), steam, and heat recycled from the fuel cell section are fed into the fuel processor to generate a gas rich in hydrogen. The fuel processor could be a reformer, a gasifier, or a hydroprocessor, depending on the hydrocarbon fuel used. The hydrogen-rich mixture is then fed to the anode side of the fuel cell power section, formed by fuel cells connected electrically in series, to generate the desired voltage. The $d-c$ power obtained is then processed by the power conditioner (at about 95\% efficiency) to produce the a-c power to meet the user requirements. The efficiency of the system described above is compared with the conventional systems in Figure 1.4.

If the fuel cell is located on-site (at the point where the electricity will be used), system efficiency can be greatly improved by cogeneration - the production of electricity and the effective use of the heat generated by the inefficiencies discussed in Chapter 5.

The conservation potential of the fuel cell can be seen in comparisons of its heat rate (the number of British thermal units of fuel required to produce 1 kilowatt-hour of electric energy) with that of other types of power plants over a wide range of loads (Figure 1.4). Fuel cells installed for loadfollowing duty would enable other generators to operate at their most efficient rate. Through cogeneration, as much as $90 \%$ of the heating value of the fuel can be put to work (Figure 1.5) for a phosphoric acid fuel cell system. 
A number of fuel cell cogeneration system studies for residential and industrial applications have shown energy savings of up to $50 \% .^{7}, 8$ Another study $^{4}$ of an integrated coal gasifier/molten carbonate fuel cell power plant with a steam turbine bottoming cycle to recover waste heat reports an overall coal to a-c power efficiency of $50 \%$.

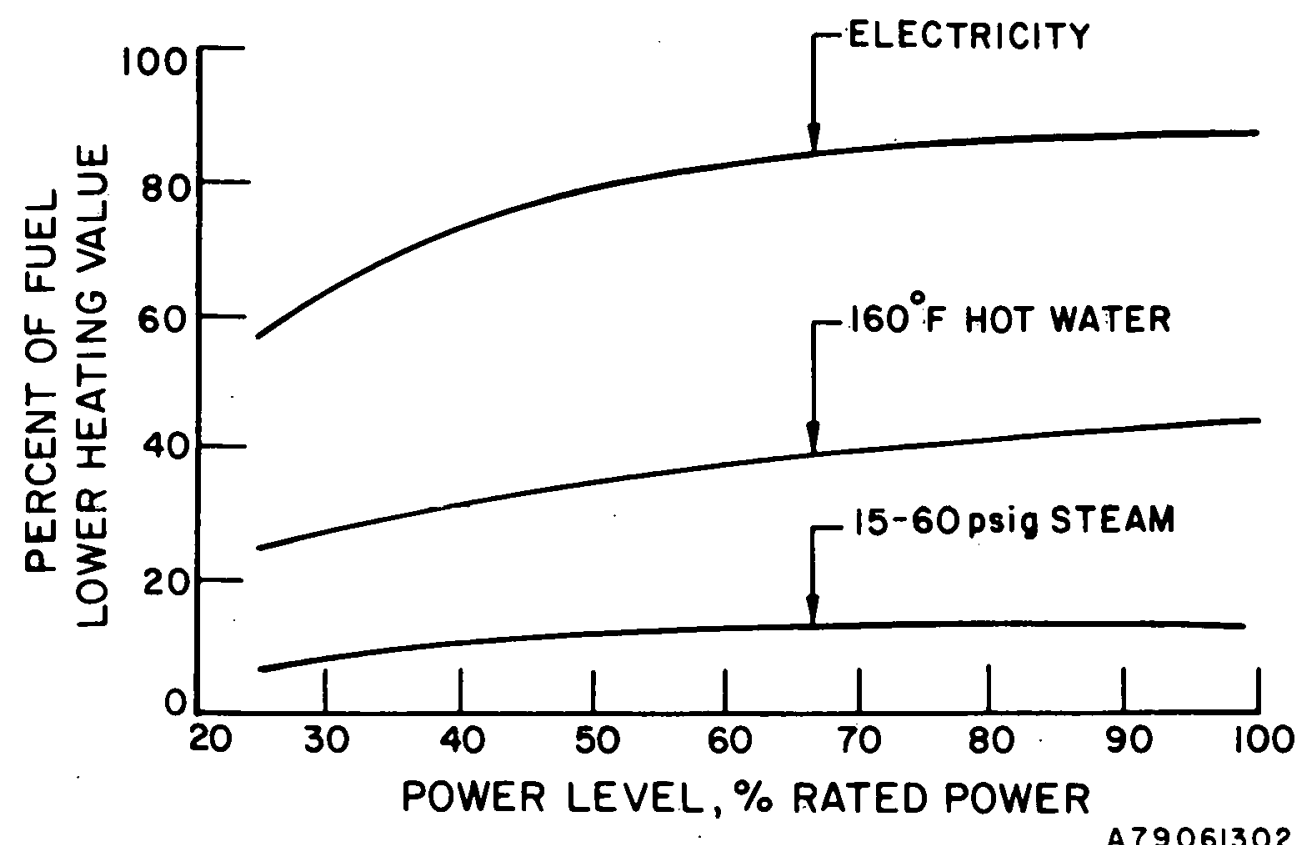

Figure 1.5. PRELIMINARY FUEL UTILIZATION CHARACTERISTICS FOR A FUEL CELL POWER PLANT ${ }^{8}$

Types of Fuel Cells

Fuel cells are usually classified according to the type of electrolyte or ion-conducting media used and the temperature of operation, as shown in Figure 1.6, which also shows fuel quality requirements. A brief introduction to the four fuel cell types follows.

Solid oxide Fuel Cells. Fuel cells with solid oxide electrolytes operate at temperatures above $800^{\circ} \mathrm{C}$ using non-noble metal electrodes. The electrolyte is usually yttria or calcia stabilized zirconia $\left(\mathrm{ZrO}_{2}\right)$, which conducts oxygen ions at the operating temperature. Because of their high operating temperature, solid oxide fuel cells will offer high-quality waste heat that can be utllized either in cogeneration or in a bottoming cycle, hence giving the potential for 


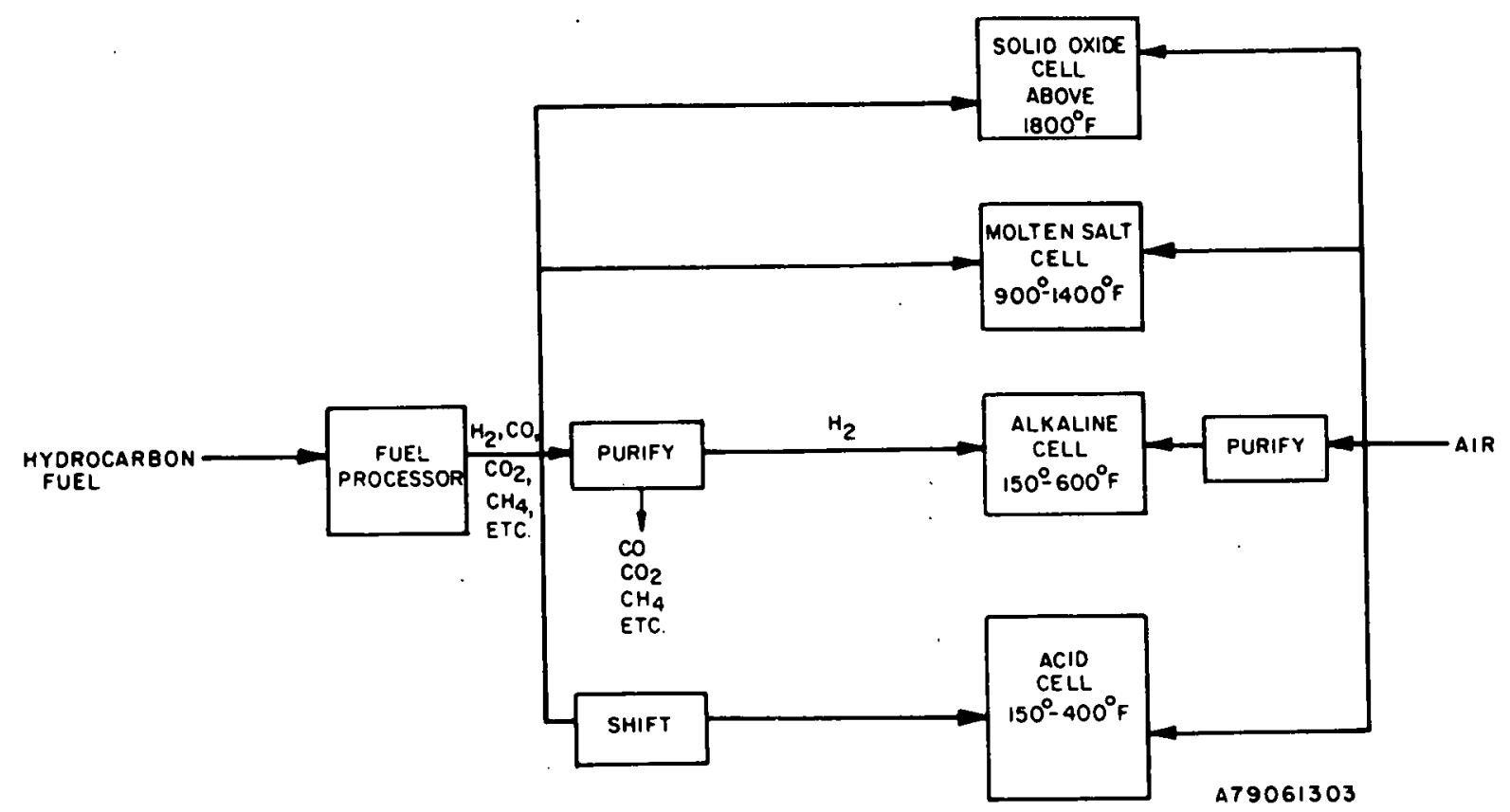

Figure 1.6. FUEL CELL TYPES ${ }^{9}$

increasing overall system efficiency. Solid oxide fuel cell technology is still at the research stage. Three of the major prohlems yet to be solved are -

1. Efficient contact of electrodes with these electrolytes, involving a solid/solid interface, is difficult to achieve.

2. An extremely large number of cells are needed because of the brittle and fragile nature of the solid oxide electrolytes, which limits cell size to small areas (a few square centimeters).

3. Materials that are stable at high temperatures are needed, such as cell interconnecting materials and stable electrolytes.

Molten Carbonate Fuel Cells. This type of cell operates at temperatures of $600^{\circ}$ to $700^{\circ} \mathrm{C}$, using impure hydrogen and air, non-noble metal electrodes, and an electrolyte of molten alkali-metal carbonates in a porous ceramic carrier (tile). As with solid oxide cells, high-quality waste heat is available for use in cogeneration or in a bottoming cycle to increase overall system efficlency. Molten salt fuel cells are entering the pilot plant technology stage. The problems associated with molten carbonate fuel cells are -

1. Carbon dioxide must be recycled from the anode to the cathode for efficient and cost-effective operation.

2. Molten carbonate electrolytes are lost by evaporation, creepage, and corrosion. 
3. Electrolyte tile integrity and corrosion resistance of cell hardware must be improved for successful long-term (approximately 40,000 hours) operation.

Acid Fuel Cells. Many acid electrolytes have been considered for use in fuel cells because acids are tolerant to carbon dioxide, which allows the use of impure hydrogen and air. $\mathrm{H}_{3} \mathrm{PO}_{4}$ fuel cells are the most advanced of all the fuel cell technologies: Pilot plants up to $1 \mathrm{MW}$ have been successfully operated. The following factors are important in considering the use of $\mathrm{H}_{3} \mathrm{PO}_{4}$ cells for commerical application -

1. Platinum is poisoned by carbon monoxide $(\mathrm{CO})$, reducing its electrocatalytic activity for hydrogen oxidation. Therefore, co concentrations of $4 \%$ or less in the fuel are desirable.

2. Cathode performance must be improved to improve cell performance.

3. The acid electrolyte is lost because of evaporation and corrosion of cell components. Electrolyte carryover can also cause corrosion problems downstream of the cell.

Alkaline Fuel Cells. Aqueous $\mathrm{KOH}$ electrolyte fuel cells operate at lower temperatures $\left(60^{\circ}\right.$ to $\left.120^{\circ} \mathrm{C}\right)$ and have demonstrated reliability in space applications using pure $\mathrm{H}_{2}$ and $\mathrm{O}_{2}$. The major drawback to commercialization of alkaline fuel cells is -

1. The electrolyte reacts with $\mathrm{CO}_{2}$, limiting the fuel to noncarbonaceous compounds. Even the $0.04 \% \mathrm{CO}_{2}$ in air must be removed. This can not be accomplished by present technology in a cost-effective manner.

All four fuel cell types are affected to varying degrees by impurities such as $\mathrm{H}_{2} \mathrm{~S}, \mathrm{SO}_{2}, \mathrm{Cl}, \mathrm{NO}_{\mathrm{x}}$, and $\mathrm{NH}_{3}$ in the fuel. Thus, gas clean-up schemes are necessary for the systems.

of the four types of fuel cells discussed above, the phosphoric acid and molten carbonate are in the most advanced state of development for commercial, Industrial, and residential applications. The phosphoric acid fuel cell system (first generation) will be tested in realistic utility situations in 1980, when a 4.8-MW power plant is scheduled to begin operation in New York City. Molten carbonate electrolyte fuel cells (second generation) have advanced to the stack development stage, and demonstration of this technology in realistic utility situations has been projected for 1985 . Because of these facts, this handbook will concentrate on these two systems, including their operation and application. 


\section{Basic Principles of Operation}

Genera1. Figure 1.7 is a schematic diagram of one repeating element in a stack of fuel cells. Each element is made up of an anode, where oxidation of the fuel occurs; an electrolyte, to separate the anode and cathode and to conduct the fons between them; and a cathode, where reduction of the oxidant occurs. The operation of the cell involves many complex mechanisms, which are conceptually simplified in the following discussions.

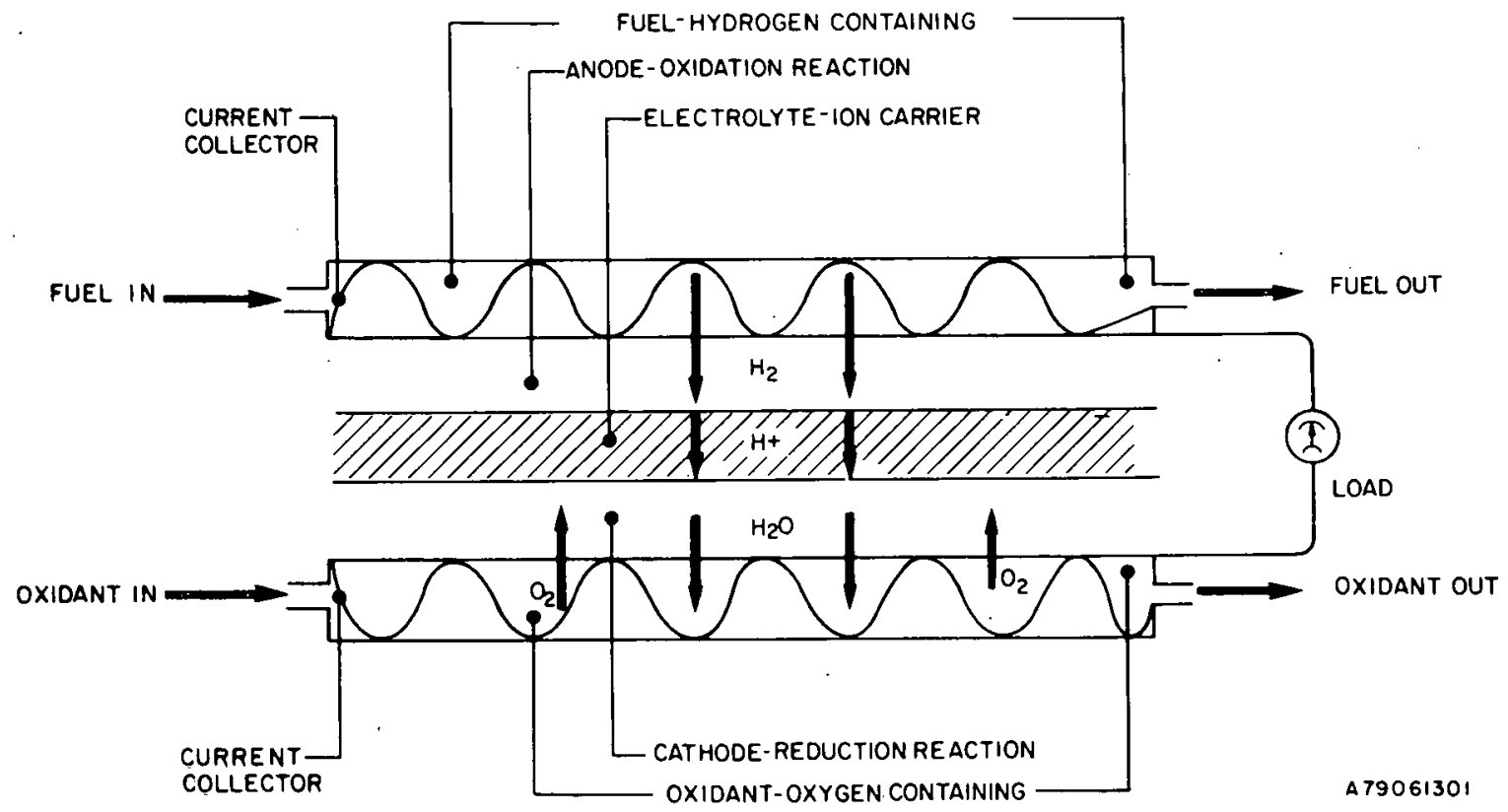

Figure 1.7a, CONCEPTUAL DIAGRAM OF A PHOSPHORIC ACID FUEL CELL

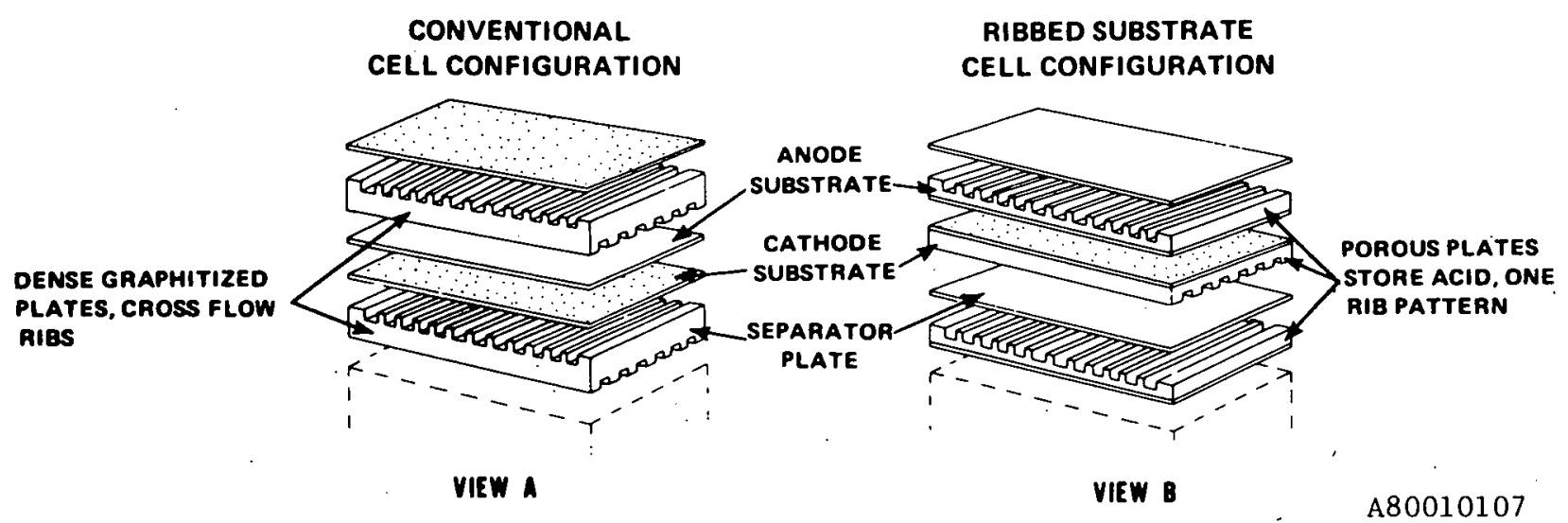

Figure 1.7b. ILLUSTRATIVE CELL CONFIGURATIONS 10 
Phosphoric Acid. Gaseous hydrogen in the fuel diffuses through the porous anode to a reaction site at the electrode (solid)/electrolyte (liquid) interface where it is electrochemically oxidized:

$$
\mathrm{H}_{2} \rightarrow 2 \mathrm{H}^{+}+2 \mathrm{e}^{-}
$$

The electrons are transported through the external circuit, and the hydrogen ions are conducted through the electrolyte to the cathode reaction sites. 0xygen, which has diffused through the cathode, reacts with the hydrogen ions and electrons (Equation 1.8), and the product water diffuses back out of the cathode :

$$
1 / 2 \mathrm{O}_{2}+2 \mathrm{H}^{+}+2 \mathrm{e}^{-} \rightarrow \mathrm{H}_{2} \mathrm{O}(\mathrm{g})
$$

The net reaction is -

$$
\mathrm{H}_{2}+1 / 2 \mathrm{O}_{2} \rightarrow \mathrm{H}_{2} \mathrm{O}(\mathrm{g})
$$

Molten Carbonate. The electrolyte is a mixture of alkali metal carbonates (a molten ionic conductor at the cell operating temperatures of $600^{\circ}$ to $700^{\circ} \mathrm{C}$ ) and ceramic particulates that retain the liquid. Fuel enters the anode, and the $\mathrm{H}_{2}$ reacts* at the anode/electrolyte interface according to -

$$
\mathrm{H}_{2}+\mathrm{CO}_{3}=\rightarrow \mathrm{H}_{2} \mathrm{O}+\mathrm{CO}_{2}+2 \mathrm{e}^{-}
$$

The product $\mathrm{H}_{2} \mathrm{O}$ and $\mathrm{CO}_{2}$ diffuse out of the electrode. At the cathode, Equation 1.11 takes place:

$$
\mathrm{CO}_{2}+1 / 2 \mathrm{O}_{2}+2 \mathrm{e}^{-} \rightarrow \mathrm{CO}_{3}=
$$

Note that $\mathrm{CO}_{2}$ is formed at the anode and consumed at the cathode. For a costeffective molten carbonate fuel cell system, the $\mathrm{CO}_{2}$ in the anode effluent must be recycled back to the cathode. This can be accomplished by catalytic combustion of the anode effluent to $\mathrm{CO}_{2}$ and $\mathrm{H}_{2} \mathrm{O}$ (plus $\mathrm{N}_{2}$ in the combustion air), followed by mixing with air to produce the cathode feed.

* Carbon monoxide in the fuel can also be oxidized, but a more favorable reaction for the conversion of $\mathrm{CO}$ is via conversion to hydrogen by the shift reaction, $\mathrm{CO}+\mathrm{H}_{2} \mathrm{O} \rightarrow \mathrm{CO}_{2}+\mathrm{H}_{2}$. The hydrogen formed is then consumed according to Equation 1.10 .

I N S T I T U T E.




\section{REFERENCES CITED}

1. Fickett, A. P., "Fuel Cells: Versat1le Power Generators," EPRI J., 1, 14-19 (1976) April.

2. The Energy Policy Staff, Office of Science and Technology, Considerations Affecting Steam Power Plant Site Selection.' Washington, D. C., 1968.

3. Kurtz, A. J. and Pantchenko, G., "To Measure Emissions from Powercell ${ }^{\circledR}$ PC-11A-1," Report Y-7309 prepared for Pratt and Whitney Alrcraft, East Hartford, Conn., by York Research Corporation, Stamford, Conn., April 1970.

4. United Technologies Corporation, "Integrated Coal Gasifler/Molten Carbonate Fuel Cell Power Plant Conceptual Design and Implementation Assessment," NASA Report CR 134955, Contract NAS 3-19586. South Windsor, Conn., 1977 .

5. Lueckel, W. J., Eklund, L. G. and Law, S. H., "Fuel Cel1s for Dispersed Power Generation." Paper presented at IEEE Winter Meeting, New York, January 30-February 4, 1972.

6. Fickett, A. P., "Fuel Cell Power Plants," Sci. Amer., 70-76, (1978) December.

7. Bolan, P. and Hall, E. H., "Industrial Applications of On-Site Fuel Cell Power Plants." Paper presented at the National Fuel Cell Seminar, Boston, June 21, 1977.

8. Bolan, P., "Heat pumps and Fuel Cell." Paper presented at 69th Annual Meeting of American Inst1tute of Chemical Engineers, November 27-December 4, 1976.

9. Marlanowsk1, I. G. and Rosenberg, R. B., "Developments in the Electrochemical Conversion of Natural Gas in Fuel Cells." Paper presented at the International Gas Union Natural Gas Symposium, Karlsruhe, West Germany, September 13-15, 1972.

10. Untted Technologies Corporation, "Integral Cel1 Scale-up and Performance Verif1cat1on", EPRI Report EM-1134. South Windsor, Conn., 1979. 
CHAPTER 2. ELEMENTARY ELECTROCHEMISTRY AND FUEL CELL OPERATING PARAMETERS Introduction

This chapter presents a brief introduction to the electrochemistry of fuel cells. It explains some of the basic electrochemical relationships and terminology necessary to understand how the chemical energy in the fuel and oxidant is converted to electricity.

The equilibrium characteristics of a fuel cell are related to $\Delta G^{\circ}$ for the overall cell reaction. Deviation from ideal behavior caused by physical and chemical factors (Figure 2.1) is discussed in detail. More exhaustive details of electrochemical theory can be obtained from many texts on the subject. ${ }^{1-7}$;

$\underline{\text { Reversible (Equilibrium) Electrodes }}$

The Nernst Equation. Consider an oxidation-reduction reaction such as Reaction 2.1 occurring at an electrode:

$$
\mathrm{aA}+\mathrm{ne}=\underset{\mathrm{bB}}{\mathrm{z}}
$$

At equilibrium, there is no net reaction, but there is a difference in potential between the electrode and electrolyte. Based on the following thermodynamic relationships -

$$
\begin{aligned}
& \Delta \mathrm{G}=-\mathrm{nFE} \\
& \Delta \mathrm{G}=\Delta \mathrm{G}^{\circ}+\mathrm{RT} \ln \mathrm{K}
\end{aligned}
$$

Nernst developed an equation relating this equilibrium potential, $E$, to the activities of the species involved in the reaction. In general, the Nernst Equation is written as.-

$$
E=E^{0}+\frac{R T}{n F} \ln [\text { [product of the activity of reactant species] }
$$

$E$ is the thermodynamic reversible (equilibrium) potential, and $\mathrm{E}^{0}$ is the standard electromotive force or the potential when all the species involved are at unit activity. $E^{\circ}$ is related to the standard free energies of the species by -

$$
\Delta \mathrm{G}^{\circ}=-\mathrm{nFE} \mathbf{E}^{\circ}
$$

Values of $E^{\circ}$ as a function of temperature for the water formation reaction are presented in Table A.6. 


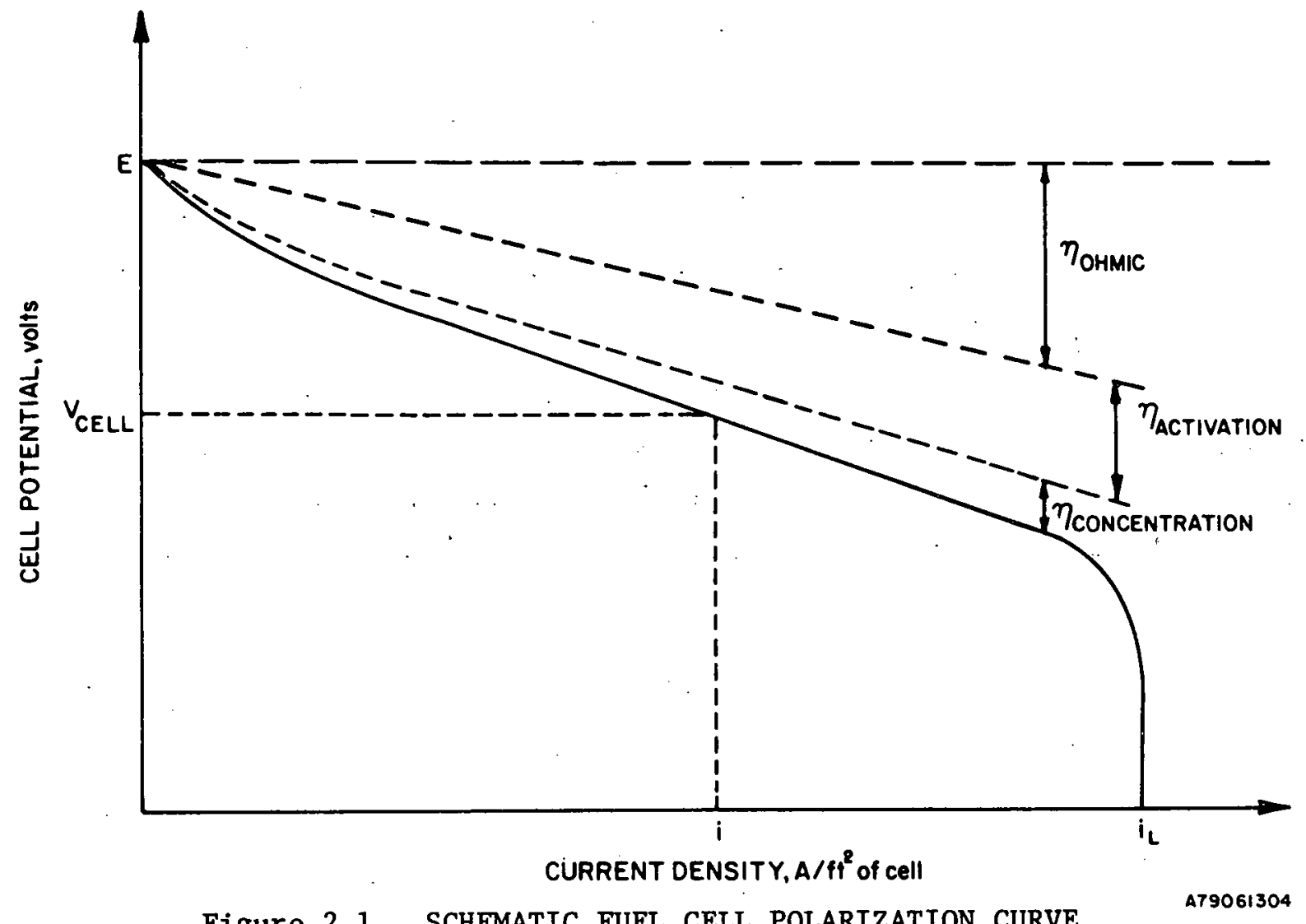

For the acid fuel cell, the overall reaction was given in Equation 1.4:

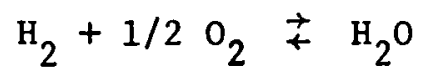

At the normal operating temperature of $190^{\circ} \mathrm{C}, \mathrm{E}^{\circ}=1.14$ volts, and the Nernst Equation is -

$$
E=1.14 \mathrm{~V}+\frac{\mathrm{RT}}{2 \mathrm{~F}} \ln \frac{\left[\mathrm{P}_{\mathrm{H}_{2}}\right]\left[\mathrm{P}_{\mathrm{O}_{2}}\right]^{1 / 2}}{\mathrm{P}_{\mathrm{H}_{2} \mathrm{O}}}
$$

The molten carbonate reactions were given in Equations 1.10 and 1.11:

$$
\begin{aligned}
& \mathrm{H}_{2}+\mathrm{CO}_{3}=\mathrm{H}_{2} \mathrm{O}+\mathrm{CO}_{2}+2 \mathrm{e}^{-} \\
& \mathrm{CO}_{2}+1 / 2 \mathrm{O}_{2}+2 \mathrm{e}^{-} \rightleftarrows \mathrm{CO}_{3}=
\end{aligned}
$$
$\begin{array}{lllllllll}\text { I N S T I T U T } & \text { T }\end{array}$
O F
G A S
T E C H N O L O G Y 
Because $\mathrm{CO}_{2}$ is fed to the cathode and produced at the anode, the concentrations are not necessarily equal, so the overall reaction is written as -

$$
\mathrm{H}_{2}+\left[\mathrm{CO}_{2}\right]_{\mathrm{c}}+1 / 2 \mathrm{O}_{2} \rightarrow\left[\mathrm{CO}_{2}\right]_{\mathrm{a}}+\mathrm{H}_{2} \mathrm{O}
$$

$E^{\circ}=1.019$ volts at $650^{\circ} \mathrm{C}$, and the Nernst equation can be written as -

$$
E=1.019 V+\frac{R T}{2 F} \ln \frac{\left[\mathrm{P}_{\mathrm{H}_{2}}\right]}{\left[\mathrm{P}_{\left.\mathrm{CO}_{2}\right]_{\mathrm{a}}\left[\mathrm{P}_{\mathrm{H}_{2} \mathrm{O}}\right]}\right.}+\frac{\mathrm{RT}}{2 \mathrm{~F}} \ln \left[\mathrm{P}_{\left.\mathrm{CO}_{2}\right]_{\mathrm{c}}\left[\mathrm{P}_{\mathrm{O}_{2}}\right]^{1 / 2}}\right.
$$

$E$ can be less or greater than $E^{\circ}$ depending on the sign and magnitude of the logarithmic, concentration-dependent terms of Equations 2.6 and 2.8 .

Exchange Current. Current is related to the electrochemical reaction rate by -

$$
i=\mathrm{nFr}
$$

At equilibrium, the forward and reverse reaction rates of Reaction 2.1 are equal. They produce currents equal in magnitude but opposite in sign. The magnitude of the currents is called the equilibrium exchange current density, $i_{0}$. High exchange current density indicates that the electrochemical reaction rate is high and good fuel cell performance is possible.

Non-Equilibrium Electrodes - Polarization

Chemical and physical factors associated with various elements of the cell when current is flowing limit the processes described here and in Chapter 1. These result in a reduction in voltage from the expected reversible potential, E. Knowledge of these limitations, called polarizations, overpotentials, or overvoltages, $n$, is useful when attempting to calculate efficiencies.

$$
\eta=E-V
$$

where $\mathrm{V}=$ cell voltage.

Although a discussion of fuel cell efficiencies will be reserved for a later section (Chapter 5), the factors that affect them will be discussed now. The total polarization of the electrode is the sum of these factors.

Activation Polarization - Tafel Equation. Most chemical reactions involve an energy barrier that must be overcome by the reacting species. This activation energy results in activation polarization, $\eta_{\text {act }}$, which is related to the current, 1 , by the Tafel Equation, Equation 2.11. 


$$
n_{a c t}=a+b^{\prime} \log i
$$

This can also be written as -

$$
i=i_{0} \exp \left(2.3 n_{a c t} / b^{\prime}\right)
$$

where $b^{\prime}$ is referred to as the Tafel slope obtained from plots of $\log i$ versus $\eta$. The exchange current can be determined experimentally by extrapolating plots of $\log i$ versus $n$ to $n=0$. Equation 2.12 describes either the fuel cell anode or the cathode when the appropriate values for $i_{0}, \eta$, and $b^{\prime}$ are used.

Activation polarization is related to the slow step in the reaction sequence. The slow step could be adsorption of reactant onto the surface, electron transfer, desorption of product, or any other step in the reaction sequence. Of course, the slow step depends on the magnitude of the potential energy barrier that must be overcome. As temperature increases, activation polarization usually decreases.

Concentration Polarization - The Limiting Current. Concentration polarization occurs when the electrode reaction is hindered by mass transport effects. The controlling process in the case of concentration polarization may be slow diffusion in the gas phase through the pores of the electrode, solution/ dissolution of reactants/products into/out of the electrolyte, or diffusion through the electrolyte to a reaction site. At practical current densities, the latter predominates. When the electrode is completely governed by diffusion processes because of low reactant concentration in the feed gases or because of conversions approaching $100 \%$ (reactants depleted), the limiting current, $i_{L}$, is reached. This situation is characterized by a rapid drop in cell voltage, as shown in Figure 2.1.

The limiting current, $i_{L}$, can be calculated from the diffusion coefficient of the reacting ions, $D$, the bulk concentration of the reacting ions, $C_{B}$, and the thickness of the diffusion layer, $\mathrm{X}$, by applying Fick's Law:

$$
i_{L}=\frac{D_{B F C}}{X}
$$

For an electrode free from activation polarization (that is, the reaction is fast), the concentration overpotential is -

$$
n_{\text {conc }}=\frac{R T}{n F} \ln \left(1-\frac{i}{i_{L}}\right)
$$

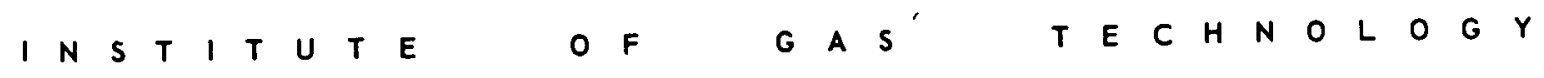


Total Electrode Polarization. The total overpotential is the sum of the activation and concentration polarizations.

$$
\eta=n_{\text {act }}+\eta_{\text {conc }}
$$

The electrode voltage is defined as the sum of the equilibrium potential and the polarization*:

$$
v_{e}=E_{e}+n_{e}
$$

The signs of the quantities in Equation 2.16 are always such that $\mathrm{V} \leq \mathrm{E}$ so that Equation 2.16 is applicable to both anode and cathode.

Ohmic Polarization - iR Losses. When an anode and cathode are connected" to an external load (Figure 1.7), the circuit is complete and current flows. Resistance to conduction of ions through the electrolyte, electrons through the electrodes and current collectors, and by contact resistances (between components) causes ohmic or iR polarization. Because both fuel cell electrodes and the electrolyte obey Ohm's Law, it is easy to calculate the voltage gradient (and loss) required to force ionic and electronic conduction:

$$
\eta_{\mathrm{ohm}}=\mathrm{iR}
$$

where $R$ is the total cell resistance including electronic, ionic, and contact resistances.

\section{Cell Performance}

For the cell shown in Figure 1.7 , both anodic and cathodic reactions contribute to the cell voltage, and the internal resistance of the cell reduces the available voltage. Therefore,

$$
\mathrm{V}_{\text {cell }}=\mathrm{V}_{\text {anode }}+\mathrm{V}_{\text {cathode }}-i R
$$

\footnotetext{
In Equation 2.16, $\mathrm{E}_{\mathrm{e}}$ is not the Nernst potential for a complete cell (Equation 2.6 or 2.8), but is the Nernst potential of efther the oxidation or reduction half-cell reaction, as measured against an inert reference electrode. A detailed discussion of this concept is not germane to this text, but a simplified discussion can be found in Reference 3 and rigorous treatment in References 4 and 5 .
} 
where $\mathrm{V}_{\text {anode }}$ and $\mathrm{V}_{\text {cathode }}$ are determined experimentally or by Equation 2.16. The effect of the polarizations has been shown qualitatively in Figure 2.1

Polarization cannot be eliminated, but can be minimized by cell design. The iR loss can be reduced by using thin electrolytes and by efficient contacts between electrode and leads. Temperature and electrolyte composition also influence the cell resistance.

Concentration polarization is dependent on the mass transport properties of the system. Mass transfer is a function of temperature, pressure, concentration, and the physical properties of the system. In a fuel cell, the reactants must diffuse through the tortuous paths of the porous electrode. This makes electrode structure important. The electrochemical reaction rate is a function of the concentration of the reacting species so, as the conversion increases, the concentration polarization becomes more severe.

Activation polarization depends upon the fundamental electrochemical reaction rate, which is also a function of temperature, pressure, and concentration. However, because the fuel cell reactions under consideration are cata1ytic, the activation polarization can be changed by using different catalysts. Fuel Cell Operating Variables

From the previous discussion it is apparent that many of the same variables affect ohmic, concentration, and activation polarizations. In most cases, all three are present to some degree, depending on the cell operating conditions and physical configuration. Therefore, it is difficult to quantitatively predict the effect of changing variables without the ald of experimental data. Chapters 3 and 4 present data for the phosphoric acid and molten carbonate fuel cells, that are parametric for temperature, pressure, conversion, gas composition, and impurities. A brief discussion of the influence of these parameters is given below.

Temperature. Increasing temperature w1ll enhance mass transfer, increase the reaction rate, and usually decrease cell resistance,* thus reducing

\footnotetext{
Although resistance to electronic conduction in metals increases, resistance to ionic conduction in the electrolyte decreases with increasing temperature, resulting in a net decrease in cell resistance if the electrolyte concentration remains constant.
}

I N S T I T U T E $O$ O F G A S T T E C H N O L O G Y


polarization and increasing cell performance. In the case of the acid cell, the additional benefit of increased $c 0$ tolerance at higher temperature is realized. On the other hand, increasing temperature results in increased corrosion, catalyst sintering and recrystallization, and electrolyte loss due to evaporation, so a compromise is required.

Pressure. There are multiple incentives for operating a fuel cell at elevated pressure, including integration with fuel processors, ${ }^{8}$ increased reactant partial pressure (Nernst gains), and higher gas solubilities in the electrolyte. There are also problems associated with high-pressure operation. Among these for the MCFC are the strict pressure control requirements to prevent reactant leakage through the electrolyte and seals and the effect that pressure has on the $\mathrm{C} / \mathrm{H} / 0$ thermodynamic system, which can lead to $\mathrm{C}$ deposition and $\mathrm{CH}_{4}$ formation.

Utilization. Utilization in a fuel cell (an electrochemical reactor) is analogous to conversion in any chemical reactor that dictates or is dictated by operating characteristics and system economics. High utilization in a fuel cell results in increased concentration polarization, which reduces efficiency. However, low utilization also results in low fuel cell efficiency (Chapter 5). To achieve high system efficiencies the reactant must be utilized, either in the fuel cell or elsewhere in the system. For example, in a complete fuel cell system, anode exhaust containing unreacted hydrogen is often burned to supply heat to the fuel processor. Therefore, it is worthwhile to discuss fuel and oxidant utilizations and their effects on the performance of a fuel cell.

Reactant Gas Composition. The power produced in a fuel cell is directly related to the moles of fuel and oxidant that are available for reaction. Defintion of the fuel processor and a system flow sheet to optimize efficiency requires knowledge of fuel cell performance as a function of fuel and oxidant gas compositions.

Impurities. Recent advances in hydrocarbon fuel processing have widened the range of fuels from which hydrogen can be obtained 9,10 and the variety of impurities present in the fuel cell feed. Knowledge of the effects of the various impurities on cell operation is crucial to definition of fuel treatment requirements. How clean must the fuel cell feed be? Should the impurity be

I N S T I TUTE U O F G A S T T E C H N O L O G


removed prior to processing, before the fuel cell, prior to venting, or not at al1? The answers to these questions lie in economics, fuel cell tolerance, existing impurity removal technology, and environmental considerations. 


\section{REFERENCES CITED}

1. Williams, K. R., Ed., An Introduction to Fuel Cells. New York: Elsevier, 1966.

2. McDouga11, A., Fue1 Ce1ls. New York: John Wiley, 1976.

3. Fontana, M. G. and Greene, N. D., Corrosion Engineering. New York: McGraw-Hil1, 1967.

4. Bockris, J. O'M. and Reddy, A. K., Modern Electrochemistry. New York: Plenum Press, 1970.

5. Bockris, J. O'M. and Srinivasan, S., Fuel Cells: Their Electrochemistry. New York: McGraw-Hill, 1969.

6. Sutton, G. W., Ed., Direct Energy Conversion. New York: McGraw-Hill, 1966.

7. Soo, S. L., Direct Energy Conversion. Englewood Cliffs, N. J.: Prentice-Hall, 1968.

8. United Technologies Corporation, "Integrated Coal Gasifier/Molten Carbonate Fuel Cell Power Plant Conceptual Design and Implementation Assessment," NASA Report CR 134955, Contract NAS 3-19586. South Windsor, Conn., 1977.

9. Catalytica Associates, Inc., "Assessments of Fuel Processing Alternatives for Fue1 Ce11 Power Generation," EPRI Report EM-570. Palo Alto, Calif., 1977.

10. Arthur D. Little, Inc., "Assessment of Fuel for Power Generation by Electric Utility Fue1 Cells," EPRI Report EM-695. Cambridge, Mass., 1978. 
CHAPTER 3. PHOSPHORIC ACID FUEL CELLS

\section{Introduction}

Technological advances since 1965 have been significant for the phosphoric acid fuel cell and will lead to a large-scale (4.8-MW) demonstration in a realistic utility situation in 1980. The historical development of acid cells has been discussed in detail elsewhere ${ }^{1-4}$ and will not be presented here. Although cell performance levels have not changed significantly (Figure 3.1), several achievements are notable ${ }^{2}$ :

1. Current cells require less than $4 \%$ of the noble metal catalyst used in earlier cells $\left(0.75 \mathrm{mg} / \mathrm{cm}^{2}\right.$ vs. $20 \mathrm{mg} / \mathrm{cm}^{2}$ of active cell area).

2. Life has been extended from hundreds to thousands of hours.

3. Hardware scaleability has been demonstrated.

4. Capital costs have been reduced by two orders of magnitude.

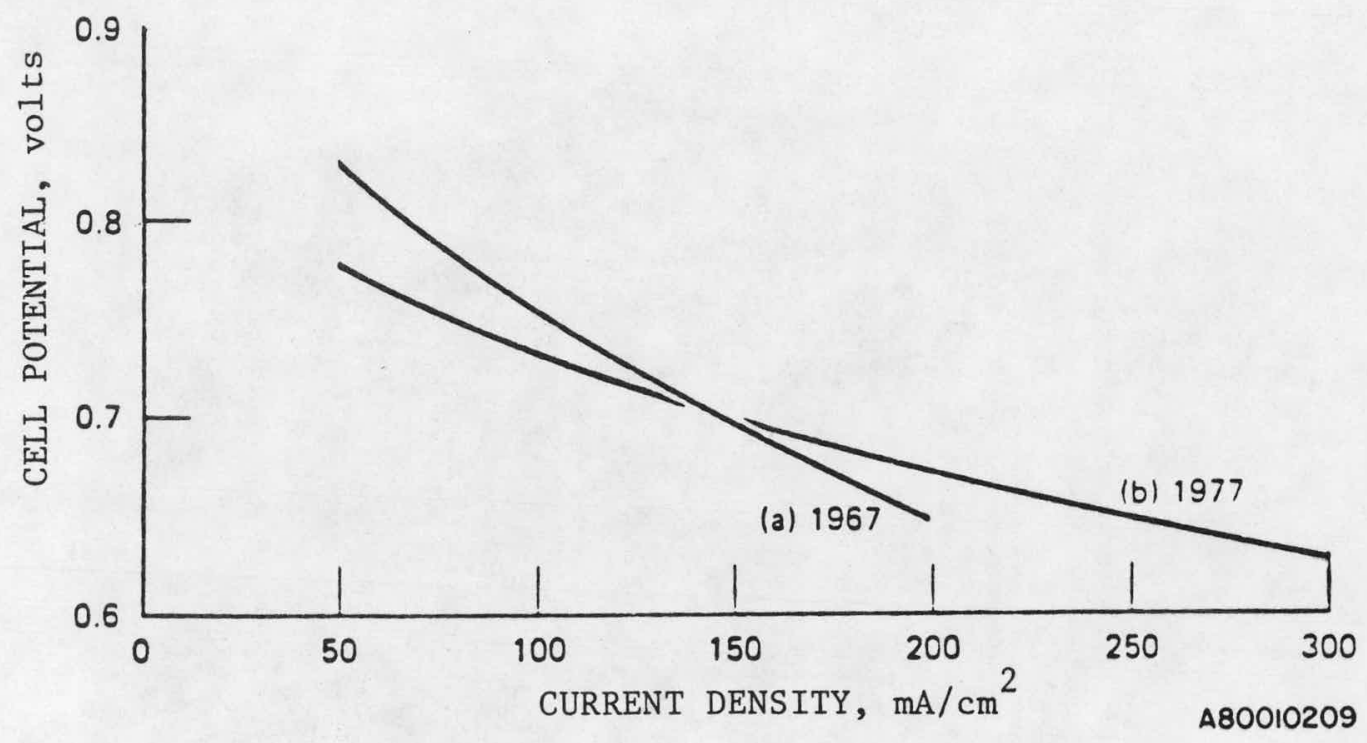

Figure 3.1. PHOSPHORIC ACID FUEL CELL POLARIZATION CURVES: (a) $160^{\circ} \mathrm{C}, 1$ atm, AIR, PLATINUM LOADING OF $20 \mathrm{mg} / \mathrm{cm}^{2}$ (b) $190^{\circ} \mathrm{C}, 3 \mathrm{~atm}$, AIR, PLATINUM LOADING OF $0.75 \mathrm{mg} / \mathrm{cm}^{2}$ HYDROGEN FUEL IN BOTH CASES (Figure originally presented at the Spring 1977 Meeting of the Electrochemical Society, Inc., held in Philadelphia)

State-of-the-art phosphoric acid fuel cells operate at $150^{\circ}$ to $200^{\circ} \mathrm{C}$ and 1 to 3 atmospheres. The electrical operating point is 0.55 to 0.65 volts/cell at 100 to $400 \mathrm{~mA} / \mathrm{cm}^{2}$ of electrode area. The heat of reaction, iR heat, etc., are removed by the process gases and/or by air or water intercell cooling.

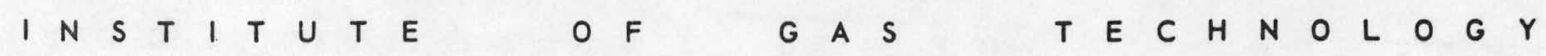


Fuel cell system efficiencies are $32 \%$ to $40 \%$ without cogeneration and $60 \%$ to $120 \%$ with cogeneration. 5 The oxidant is oxygen in air, and the fuel is hydrogen with $\mathrm{CO}_{2}, \mathrm{CH}_{4}$, and small amounts of $\mathrm{CO}$ from the methane or naphtha steam reformer.

Energy Research Corporation (ERC, a subsidiary of St. Joe Minerals Corporation) has been involved in phosphoric acid fuel cell work for about 8 years. ERC has delivered a $1.5-\mathrm{kW}$ indirect methanol-air fuel cell power plant (Figure 3.2) to the U.S. Army Mobility Equipment Research and Development Command (MERADCOM) for remote $d-c$ power generation. The ERC hardware (Figure 3.3), mass production manufacturing techniques, and performance have been completely described in many publications. ${ }^{5-10}$

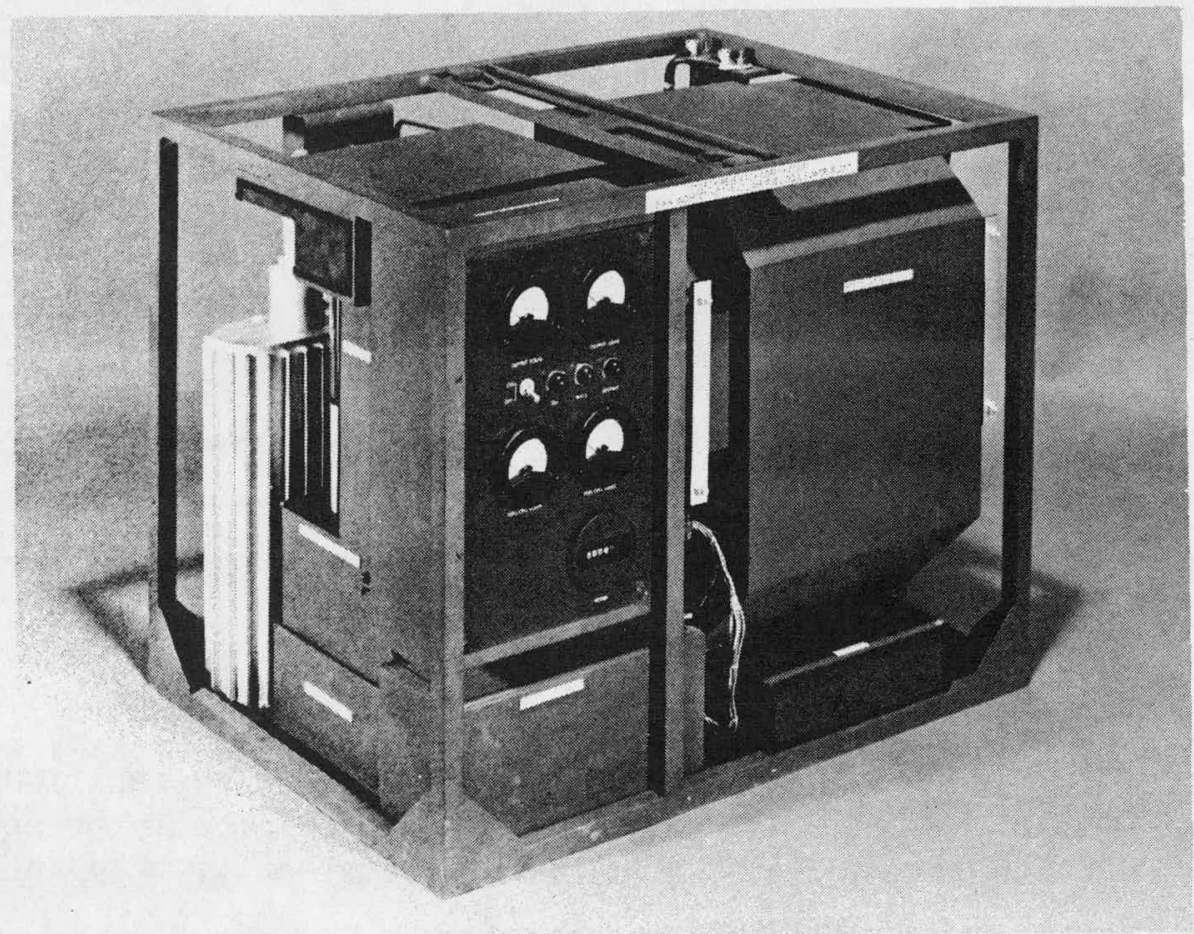

Figure 3.2. 1.5-kW INDIRECT METHANOL-AIR PHOSPHORIC ACID FUEL CELL POWER PLANT (Photo courtesy of U.S. Army MERADCOM) 

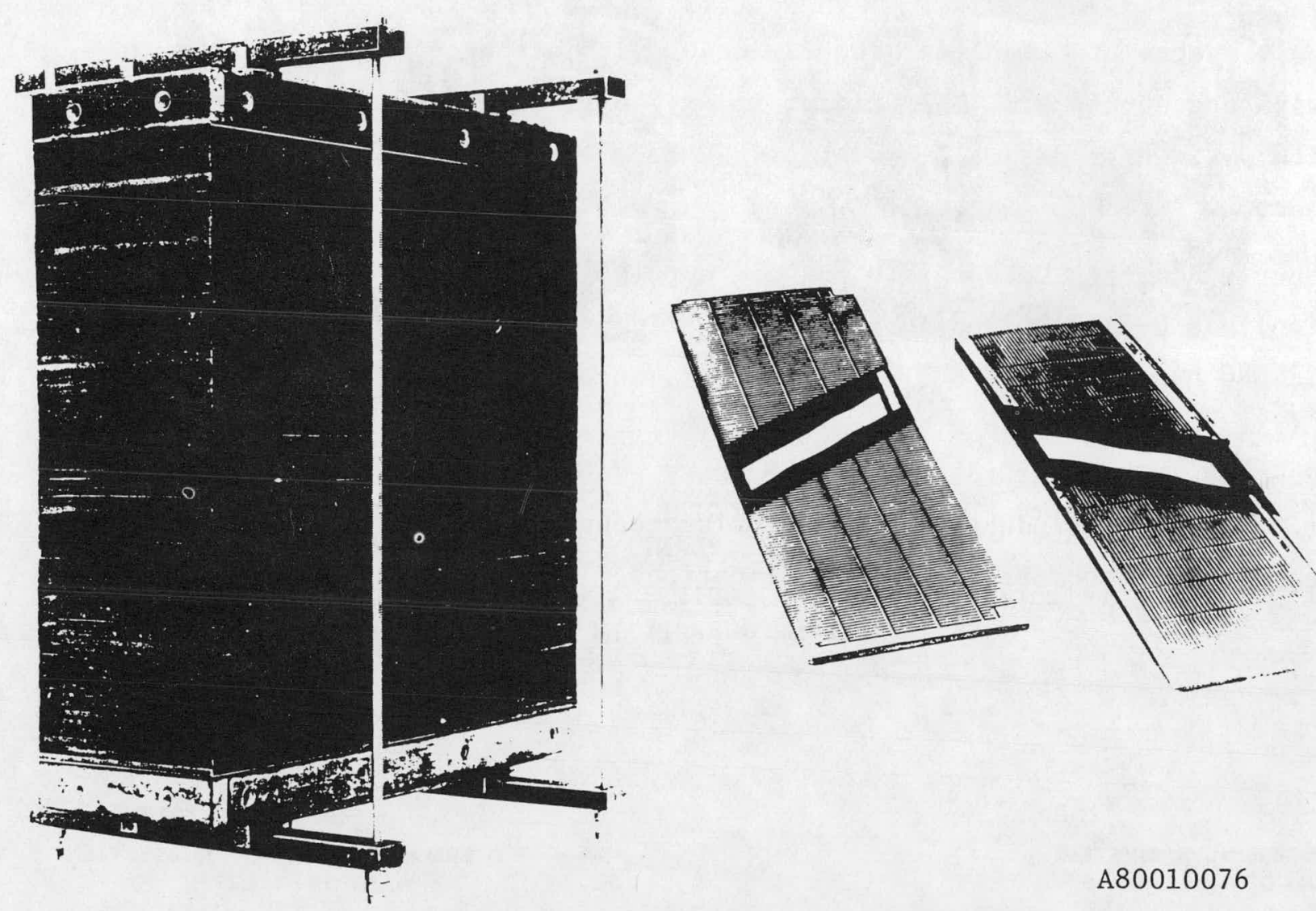

Figure 3.3 ENERGY RESEARCH CORPORATION'S PHOSPHORIC ACID FUEL CELL COMPONENTS AND STACK (Photo courtesy of ERC)

The organization with the most experience in developing, building, and running large-scale phosphoric acid fuel cell systems is Power Systems Division (PSD) of United Technologies Corporation (UTC). The team at UTC has successfully field-tested 60 units of $12.5-\mathrm{kW}$ each in a variety of applications (residential, commercial, industrial) in 19 states and the District of Columbia ${ }^{11}$ under the Team to Advance Research for Gas Energy Transformation (TARGET), a consortium of 32 gas utilities, program. These circa 1967 fuel cells operated on reformed natural gas supplied by a self-contained reformer. A larger (40-kW) system (Figure 3.4) had accumulated 14,000 hours as of July 1977. ${ }^{2}$ An advanced model of the 40-kW unit is projected for field testing in 1980. Further large unit experience was gained in early 1977 with the 1100-hour test of a 1-MW system at UTC. This pilot power plant is shown in Figure 3.5. Data obtained from this test were used to design the 4.8-MW system (Figure 3.6), scheduled to go on line in 1980 in a program jointly 


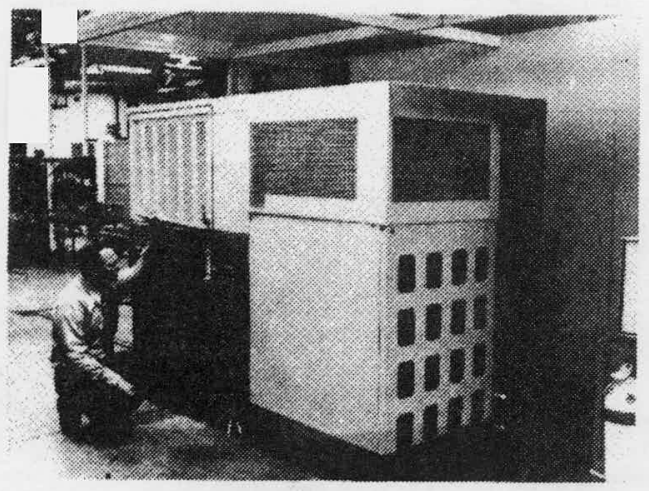

A80010077

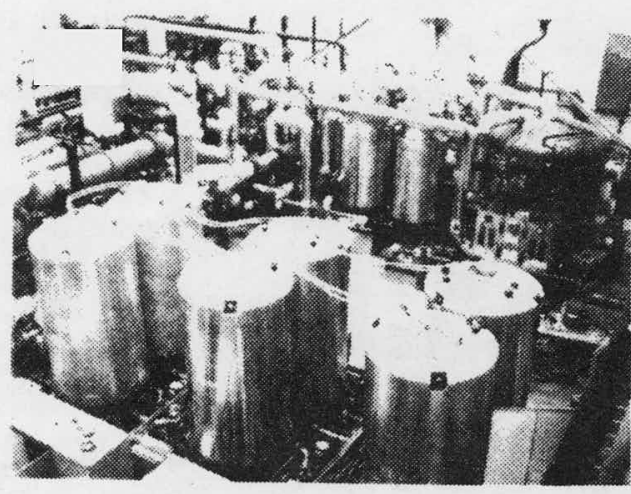

A80010078

Figure 3.4. (Left) UNITED TECHNOLOGIES' 40-kW PHOSPHORIC ACID FUEL CELL POWER PLANT ${ }^{13}$

Figure 3.5. (Right) UNITED TECHNOLOGIES' 1.0-MW PHOSPHORIC ACID FUEL CELL PILOT POWER PLANT ${ }^{13}$

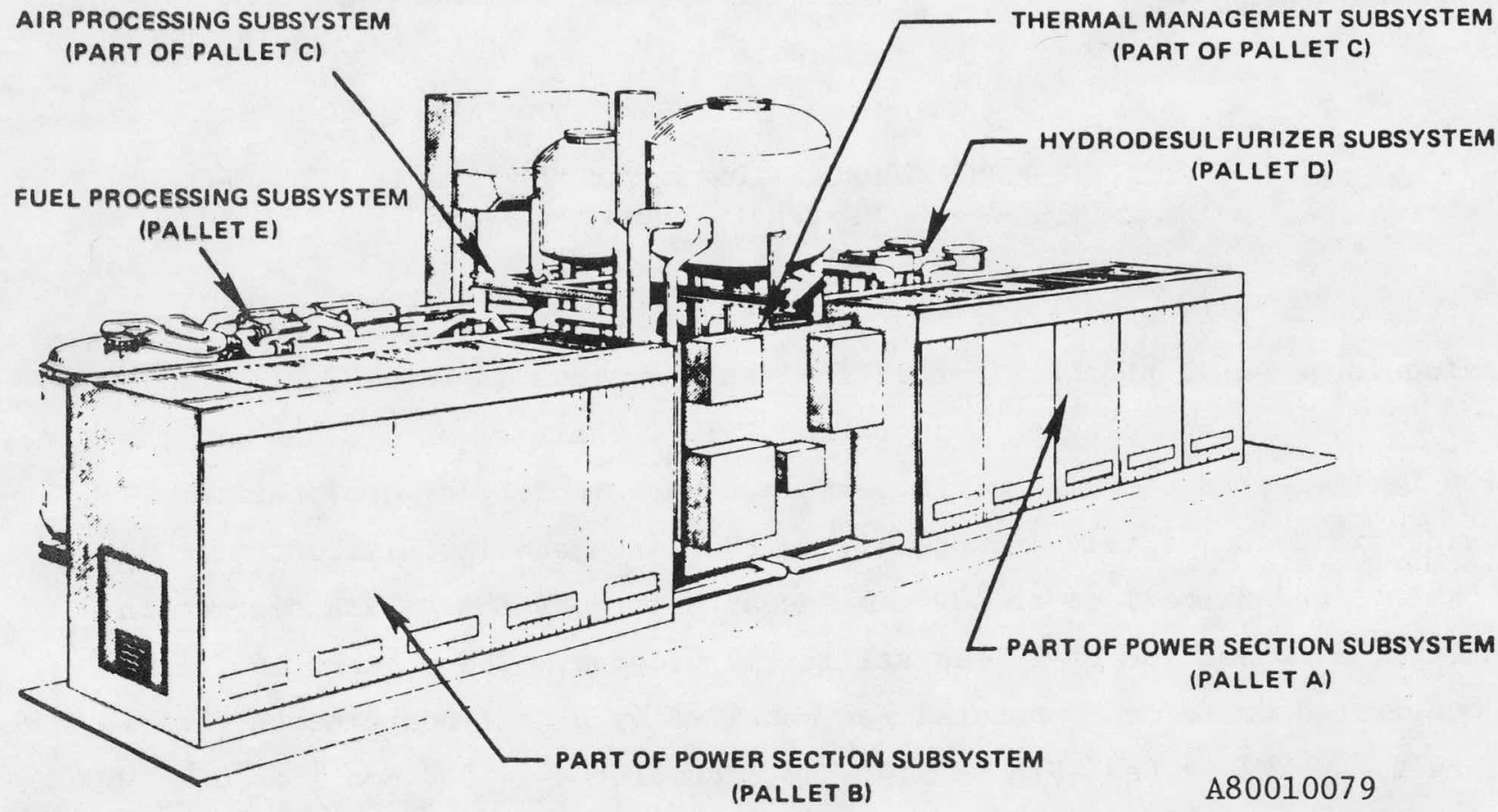

Figure 3.6a. UNITED TECHNOLOGIES' 4.8-MW PHOSPHORIC ACID FUEL CELL POWER PLANT DEMONSTRATOR (Fuel Cell d-c Module) 14 


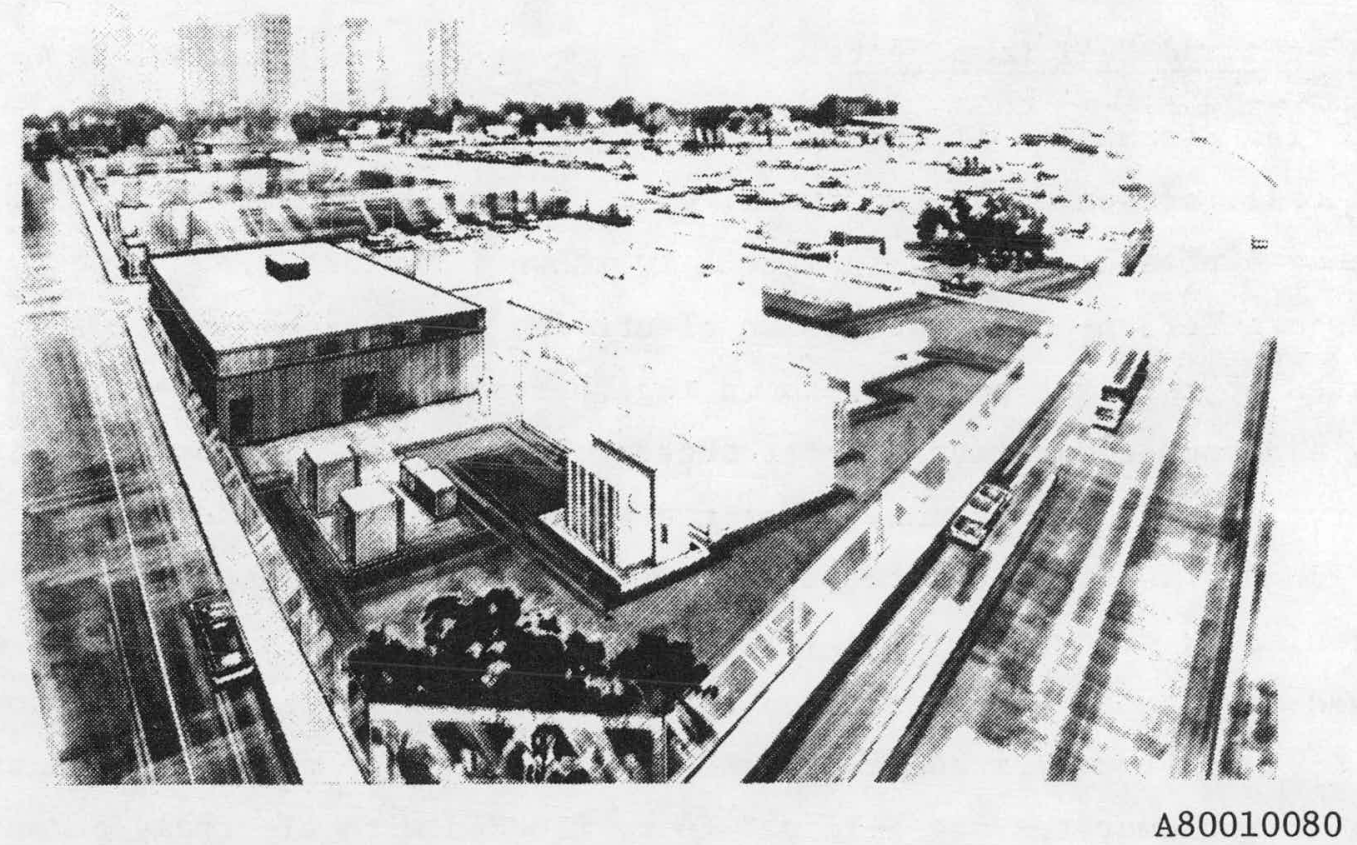

Figure 3.6b. UNITED TECHNOLOGIES' 4.8-MW PHOSPHORIC ACID FUEL CELL POWER PLANT DEMONSTRATOR (Power Plant Artist's Conception) 15

funded by EPRI, DOE, UTC, and a utility group led by the Consolidated Edison Company of New York. Successful demonstration of the 4.8-MW phosphoric acid fuel cell system could lead to the commercialization of multi-megawatt systems in the 1980 's.

Although the phosphoric acid fuel cell system is on the verge of largescale demonstration, a number of problems are still receiving attention:

1. The platinum catalyst is expensive and suffers a reduction in surface area and performance due to sintering. The CO-poisoning problem mentioned earlier has been somewhat mitigated by operation at higher temperatures, ${ }^{2}$ although increasing the temperature also increases the sintering. CO-tolerant catalysts such as mixtures of $\mathrm{Pt}, \mathrm{Rh}$ and $\mathrm{WO}_{3}$ have also been used. 6

2. Electrolyte is lost because of evaporation. This problem can be alleviated by incorporation of an electrolyte reservoir in the cell. However, this reservoir can increase concentration polarization in the cell, and the evaporated acid condenses downstream of the cell, creating corrosion problems.

3. The most difficult chalienge concerns the irreversibility (severe activation polarization) and lack of understanding of the reduction of oxygen at the cathode. This area also offers considerable opportunity for improvement of the phosphoric acid fuel cell performance. 
The brief discussion of the basic principles of operation of the phosphoric acid fuel cell, presented in Chapter 1, will be expanded in this section. A schematic of a phosphoric acid fuel cell is shown in Figure 3.7. Both electrodes are Teflon-bonded diffusion electrodes consisting of porous agglomerates of catalyst particles held together by a Teflon binder ${ }^{17}$ and backed by a porous conductive support sheet. Pores in the hydrophobic Teflon region serve as diffusion channels for the gaseous reactants and products. The hydrogen diffuses through these pores to a catalyst agglomerate made up of electronically conductive catalyst particles of platinum ( $\mathrm{WO}_{3}$, $\mathrm{Rh}$ and $\mathrm{Ru}$ may be used as dopants), supported on carbon to achieve lower catalyst loadings ( 0.25 to $0.75 \mathrm{mg} \mathrm{Pt} / \mathrm{cm}^{2}$ of anode area and 0.5 to $0.75 \mathrm{mg} / \mathrm{cm}^{2}$ of cathode area). The catalyst agglomerates are believed to be flooded with electrolyte during cell operation. 17 When the hydrogen arrives at a reaction site at the catalyst/electrolyte interface, it is electrochemically oxidized according to -

$$
\mathrm{H}_{2} \rightarrow 2 \mathrm{H}^{+}+2 \mathrm{e}^{-}
$$

The electrons are transported through the external circuit, and the hydrogen ions are conducted to the cathode through the $95 \%$ to $100 \%$ phosphoric acid electrolyte held in place by an inert inorganic or polymeric matrix.

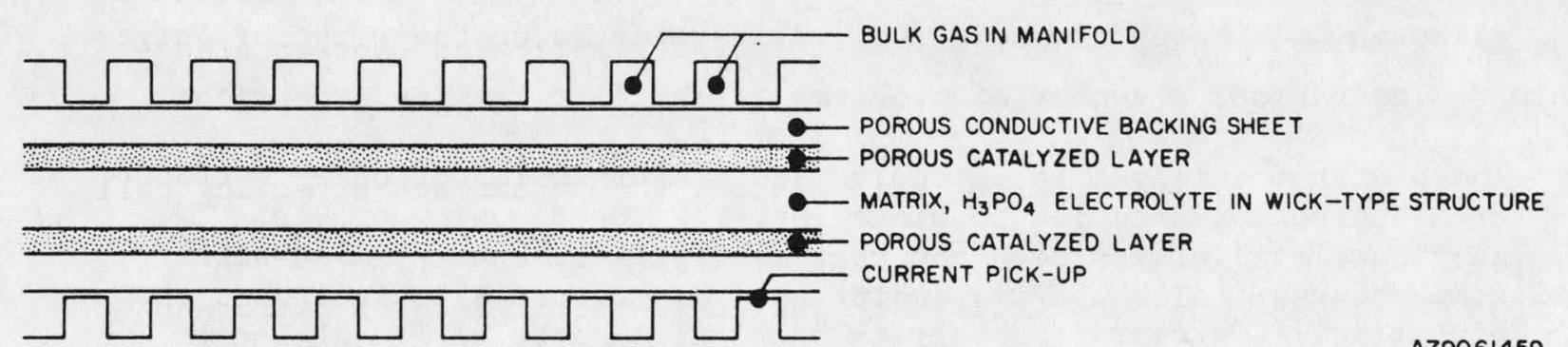

Figure 3.7. ELEMENTAL PHOSPHORIC ACID FUEL CELL SCHEMATIC ${ }^{16}$

The basic cathode structure and materials are the same as the anode's (the cathode is not doped) although the physical parameters (pore size, thickness, etc.) may be different to achieve the desired mass transfer characteristics. When the hydrogen ions arrive at the cathode reaction sites, they react with the oxygen, which has diffused through the pores of the cathode's Teflon region. The reaction is - 


$$
2 \mathrm{H}^{+}+1 / 2 \mathrm{O}_{2}+2 \mathrm{e}^{-} \rightarrow \mathrm{H}_{2} \mathrm{O}
$$

The water then diffuses back out of the cathode. The overall reaction in the phosphoric acid fuel cell is -

$$
\mathrm{H}_{2}+1 / 2 \mathrm{O}_{2} \rightarrow \mathrm{H}_{2} \mathrm{O}+\text { heat }
$$

\section{Phosphoric Acid Fuel Cell Performance}

General Considerations. Although the phosphoric acid fuel cell system is much more developed and closer to deomonstration/commercialization than other fuel cell systems, it is difficult to find clear parametric data that fully describe cell performance characteristics. Therefore, the following discussions of cell performance parameters and design considerations should be taken as directional in nature.

The performance of a typical state-of-the-art hydrogen-air phosphoric acid fue 1 cell was presented in Figure 3.1. The magnitudes of the anode, the cathode (activation plus concentration), and ohmic polarizations are shown in Figure 3.8. ${ }^{2,3}$ The upper curve represents the cell performance that could be obtained if ohmic (approximately $i 5 \mathrm{mV} / 100 \mathrm{~mA} / \mathrm{cm}^{2}$ ) and anode (approximately $5 \mathrm{mV} / 100 \mathrm{~mA} / \mathrm{cm}^{2}$ ) polarizations were eliminated. It also demonstrates the significant gains possible if the cathode polarization (approximately $400 \mathrm{mV} /$ $300 \mathrm{~mA} / \mathrm{cm}^{2}$ ) could be reduced. ${ }^{2,18}$ The relative magnitudes of the anode and cathode polarizations illustrate why most recent research is concentrated on the cathode.

The remainder of this chapter will discuss the parameters affecting cell performance, present supporting data and derived equations, and illustrate how this information is used to predict fuel cell performance at different conditions. For the purposes of this discussion, the performance of a cell operating on hydrogen and oxygen at low utilizations, atmospheric pressure, and $175^{\circ} \mathrm{C}$ will be considered as baseline. This performance is shown in Figure 3.9.

Design Considerations. Various points on the performance curve can be chosen as the operating design point. The selection affects and is affected by several factors. These include size, cost, heat removal, maximum and minimum voltage, and power constraints. The performance curve is a function of gas composition and utilization, temperature, pressure, and impurity levels. 


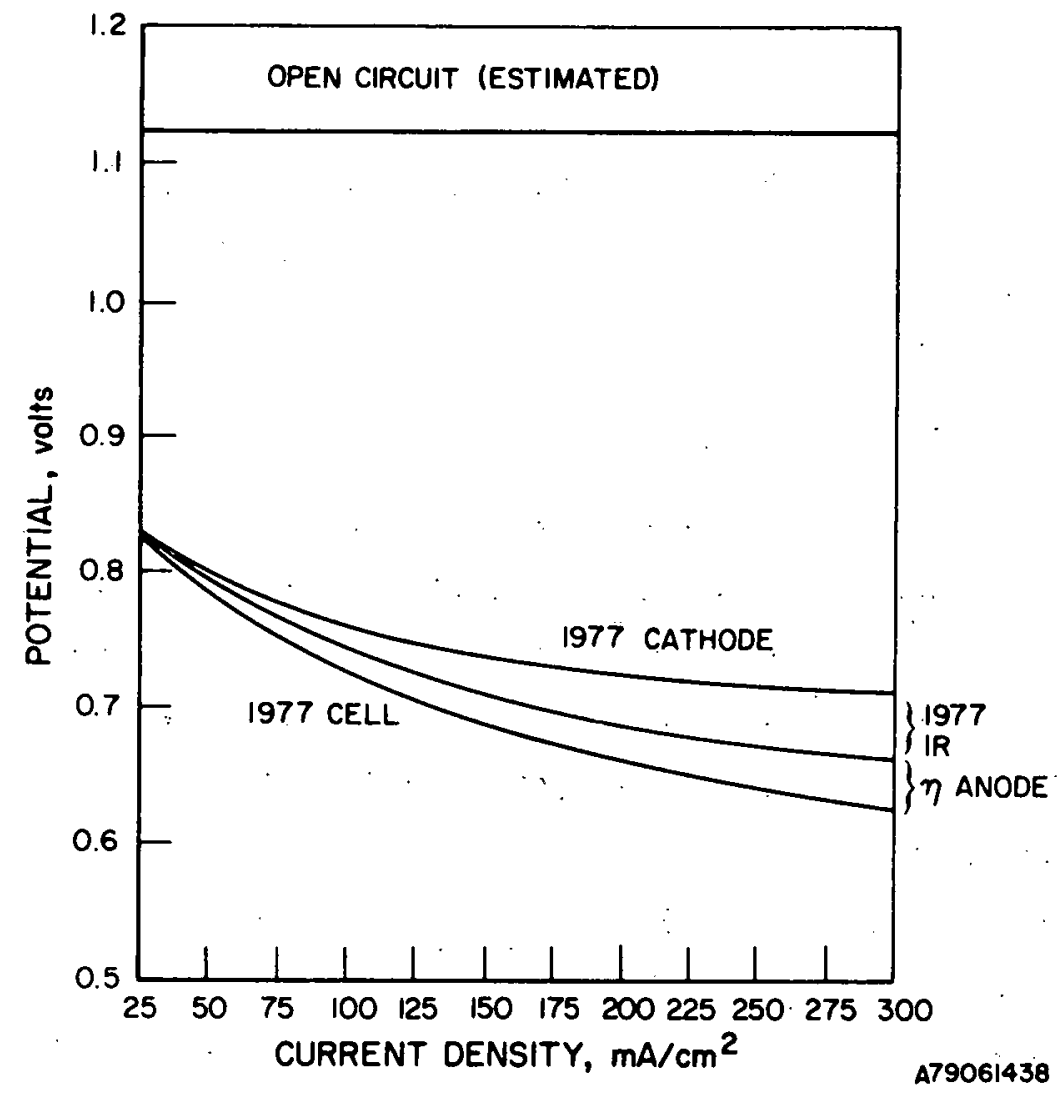

Figure 3.8. PHOSPHORIC ACID FUEL CELL AT $190^{\circ} \mathrm{C}$, $3 \mathrm{~atm}$, AIR, PLATINUM LOADING, $0.75 \mathrm{mg} / \mathrm{cm}^{2}, \mathrm{H}_{2}$ FUEL

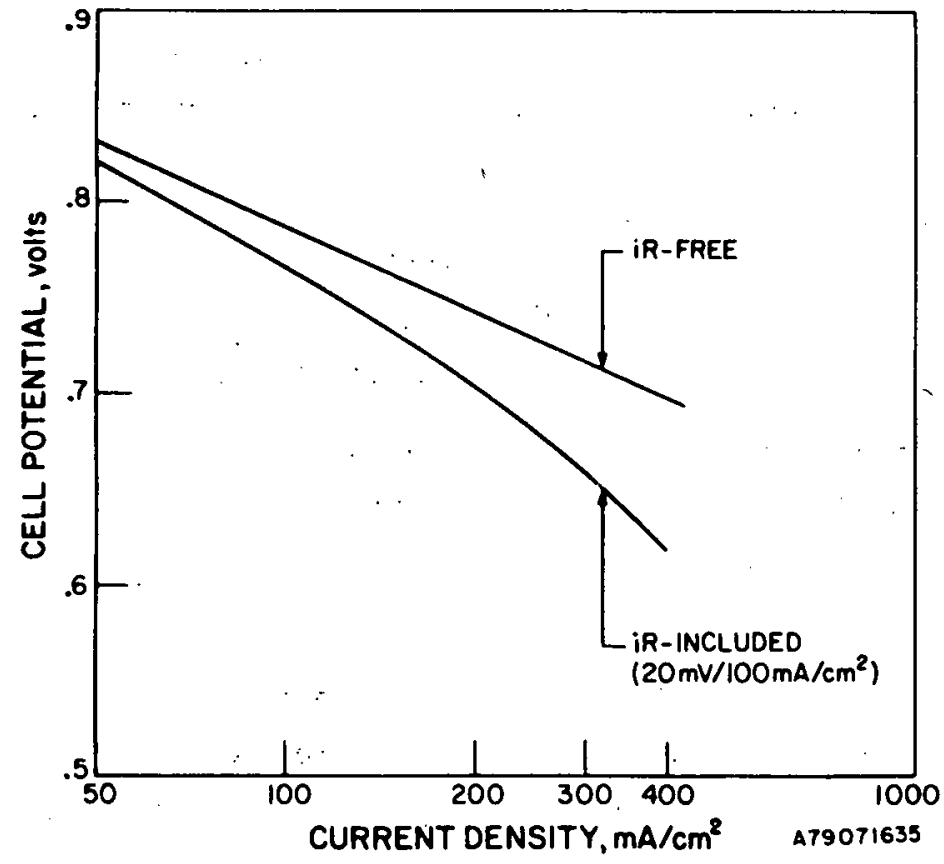

Figure 3.9. BASELINE PHOSPHORIC ACID FUEL PERFORMANCE AT $1 \mathrm{~atm}, 175^{\circ} \mathrm{C}, \mathrm{H}_{2}$ FUEL, $\mathrm{O}_{2}$ OXIDANT, LOW UTILIZATION 
The following illustrates assessment of the size, cost, and heat removal criteria: A cell operating at $100 \mathrm{~mA} / \mathrm{cm}^{2}(0.769 \mathrm{volt})$ generates $72 \mathrm{~W} / \mathrm{ft}^{2}$, whereas a cell operating at $200 \mathrm{~mA} / \mathrm{cm}^{2}\left(0.702\right.$ volt) produces $131 \mathrm{~W} / \mathrm{ft}^{2}$. Thus, to generate 1 kilowatt, the required areas are $14 \mathrm{ft}^{2}$ and $7.7 \mathrm{ft}^{2}$, respectively. Because fuel cell cost is almost directly proportional to area, substantial savings can be realized by operating at higher current density. However, the fuel cell will be less efficient. Typical fuel cells will operate in the range of 100 to $400 \mathrm{~mA} / \mathrm{cm}^{2}$ at 0.65 to $0.55 \mathrm{volt} / \mathrm{cell}$.

The voltage and power constraints arise from the fact that platinum and carbon components can corrode at cell potentials above approximately 0.8 volt. This maximum allowable voltage determines the minimum load at which the system can operate because the cell voltage increases at part load.

Effect of Temperature. From the discussion in Chapter 2, increasing the temperature is expected to increase cell performance. However, increasing the temperature has deleterious effects such as increases in catalyst sintering, cell component corrosion, electrolyte degradation, and electrolyte evaporation and concentration.13,20-24 The possibility of increased electrolyte concentration can be neglected at high utilization because the high partial pressure of product water in the gas stream maintains the: electrolyte concentration. The increase in cell performance, which can be realized by increasing operating temperature, 25,26 is shown in Figure 3.10. For a low-utilization $\mathrm{H}_{2} / \mathrm{O}_{2}$ or $\mathrm{H}_{2} /$ air fuel cell at 50 psia and $300 \mathrm{~A} / \mathrm{ft}^{2}$, the change is decribed by -

$$
\Delta \mathrm{V}_{\mathrm{T}}(\mathrm{mV})=0.64\left(\mathrm{~T}_{2}-\mathrm{T}_{1}\right)\left({ }^{\circ} \mathrm{F}\right)
$$

between $375^{\circ}$ and $425^{\circ} \mathrm{F}$.

Although temperature has only a minimal effect on the hydrogen oxidation reaction at the anode, it is important in terms of anode poisoning. Figure 3.11 shows that increasing the cell temperature results in increased anode tolerance to $C O$ poisoning. This explains the higher slope for Co-containing fuels in Figure. 3.11 described by -.

$$
\Delta \mathrm{V}_{\mathrm{T}}(\mathrm{mV})=1.22\left(\mathrm{~T}_{2}-\mathrm{T}_{1}\right)\left({ }^{\circ} \mathrm{F}\right)
$$

A more detailed discussion of poisons can be found in the Effect of Impurities section of this chapter. 


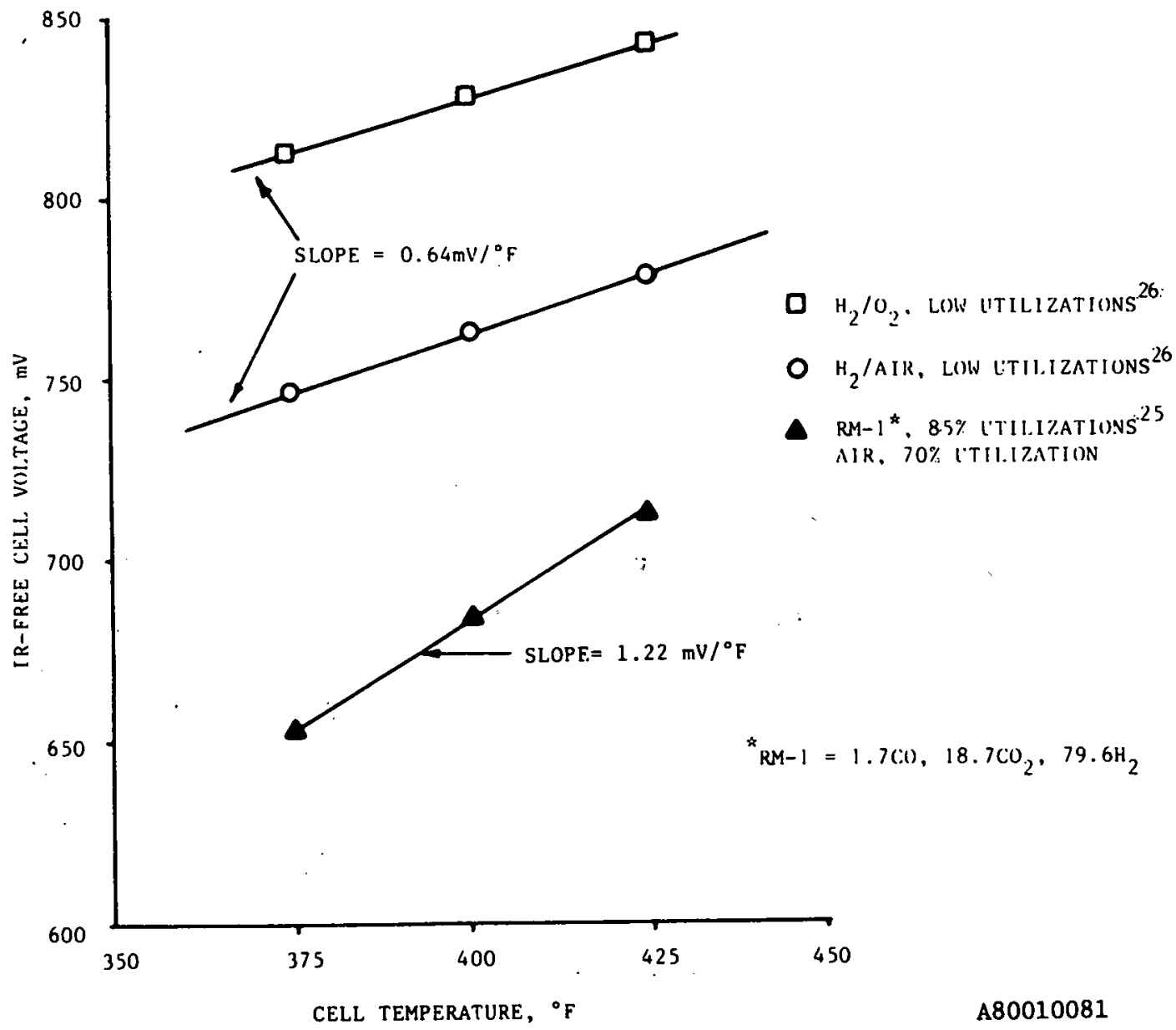

Figure 3.10. EFFECTS OF TEMPERATURE ON PHOSPHORIC ACID FUEL CELL PERFORMANCE AT 50 psia, $300 \mathrm{ASF}, 190^{\circ} \mathrm{F}$ ANODE DEWPOINT ${ }^{25,26}$

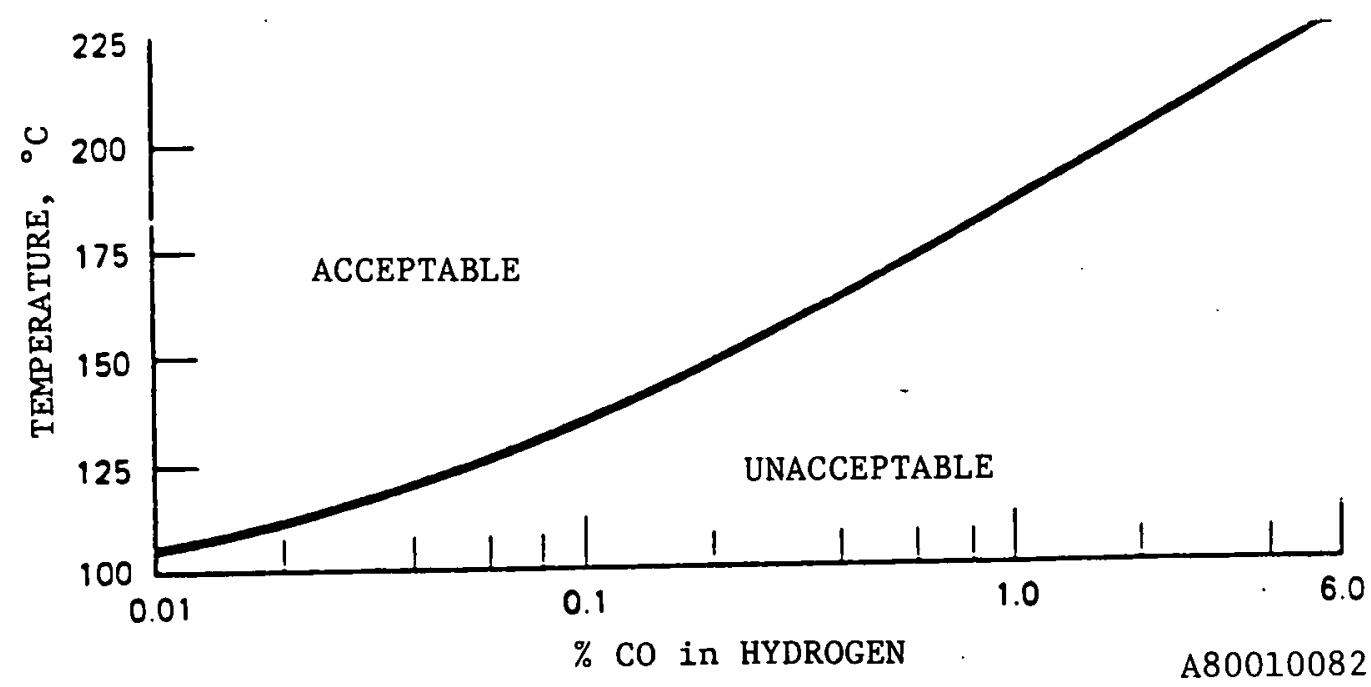

Figure 3.11. EFFECTS OF TEMPERATURE ON PHOSPHORIC ACID FUEL CELL ANODE CO TOLERANCE ${ }^{2}$ (Figure originally presented at the Spring 1977 Meeting of the Electrochemical Society, Inc., held in Philadelphia, Pennsylvania) 34 
The preceding discussion of the effect of temperature on the phosphoric acid fuel cell implies that there is great incentive to increase the operating temperature. As mentioned previously, higher temperatures would result in increased catalyst sintering, cell component corrosion, and electrolyte evaporation and degradation, which could result in performance decay and/or life limitations. State-of-the-art phosphoric acid cells operate at $190^{\circ} \mathrm{C}$, but cell package development work is in progress to lay the foundation for nigher temperature and pressure conditions in the future. 25,26

Effect of Pressure. Increasing the pressure is expected to result in higher cell performance because of decreased activation polarization at the cathode due to increased oxygen and water partial pressures. The water dilutes the acid, resulting in a higher exchange current density. Additional gains (Nernst) are realized in the open circuit potential, E:

$$
E=E^{\circ}+\frac{R T}{2 F} \ln \frac{P_{H_{2}}}{P_{H_{2} O}}+\frac{R T}{2 F} \ln \left[P_{O_{2}}\right]^{1 / 2}
$$

The calculated contribution of each of these factors is compared with experimental data in Figure 3.12. ${ }^{27}$ Figure 3.13 contains additional data ${ }^{25,26}$ that demonstrate the gains associated with higher pressure.

For Figure 3.12 at $350^{\circ} \mathrm{F}$, the theoretical line is described by -

$$
\Delta \mathrm{V}_{\mathrm{P}}(\mathrm{mV})=137 \log \frac{\mathrm{P}_{2}}{\mathrm{P}_{1}}
$$

The experimental data are also described by -

$$
\Delta \mathrm{V}_{\mathrm{P}}(\mathrm{mV})=137 \log \frac{\mathrm{P}_{2}}{\mathrm{P}_{1}}
$$

The data in Figure 3.13 are for $375^{\circ} \mathrm{F}$ and become -

$$
\Delta \mathrm{V}_{\mathrm{P}}(\mathrm{mV})=146 \log \frac{\mathrm{P}_{2}}{\mathrm{P}_{1}}
$$

which also described data in the same reference at $425^{\circ} \mathrm{F}$. This shows that the effect of pressure on cell performance is independent of temperature.- Analysis of all of the data indicate that there is no dependence on the presence of $1.7 \% \mathrm{CO}$ or the fuel and oxidant utilizations. 


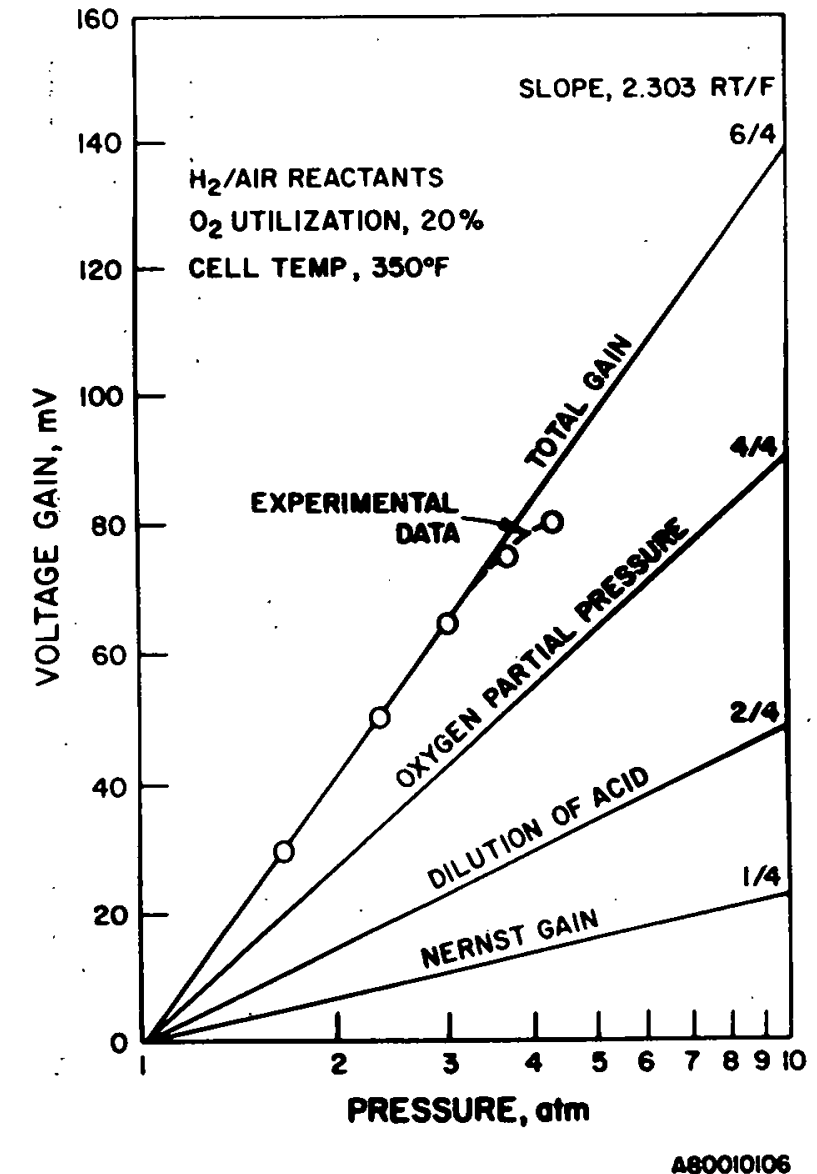

Figure 3.12. CELl VOLTAGe GAIN AT A FIXED CURRENT DENSITY AS A FUNCTION OF CELL OPERATING PRESSURE (Contribution of Different Factors Shown) ${ }^{27}$

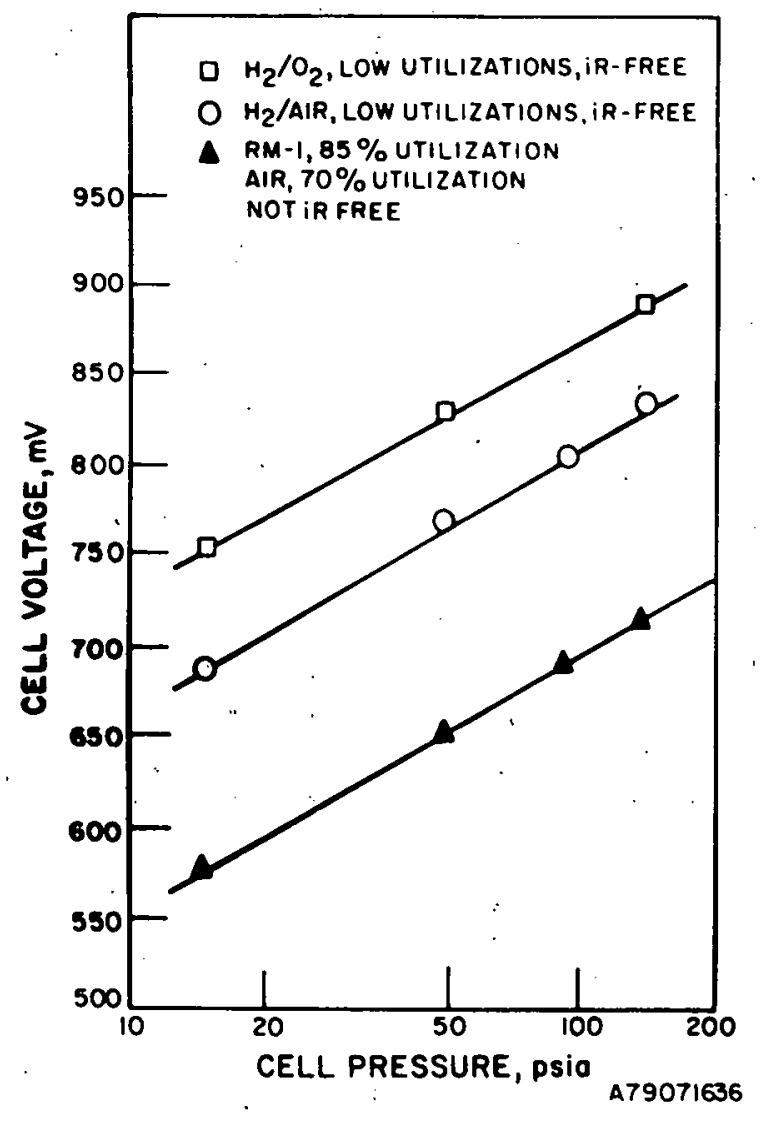

Figure 3.13. EFFECT OF PRESSURE ON CELL VOLTAGE AT $375^{\circ} \mathrm{F}, 190^{\circ} \mathrm{F}$ ANODE DEWPOINT, $300 \mathrm{ASF}^{25}, 26$ 
Although the experimentally derived equations are slightly different, the discrepancy in voltage gain when increasing pressure from 50 to 100 psi is only $3 . \mathrm{mV}$. Therefore, an average dependence is recommended:

$$
\Delta \mathrm{V}_{\mathrm{P}}(\mathrm{mV})=142 \log \frac{\mathrm{P}_{2}}{\mathrm{P}_{1}}
$$

Increases in cell performance with pressure can also be considered as increases in current density, which allow reduced fuel cell size and cost.

There are also problems associated with higher pressure such as increased component corrosion at the resulting higher voltage. The operating pressure range of interest for phosphoric acid fuel cells is 1 to 10 atmospheres.

Effect of Reactant Concentration and Utilization. Decreasing reactant utilization or inlet concentration results in decreased cell performance because of increased concentration polarization (diffusion) and Nernst losses as determined by Equation 3.6. Both are partial pressure effects and are considered simultaneously.

Oxidant. Figure 3.14 is representative of the data concerning the cathode that has been published $13,20,23,24,28$ and shows the magnitude of cathode performance improvement obtained with oxygen vs. air. ${ }^{20}$ At a constant cathode potential the current varies linearly with oxygen partial pressure. 20 Additional data on the gains associated with using oxygen at the cathode instead of air are contained in Figures 3.10 and 3.13. The data in these figures are represented by -

$$
\Delta \mathrm{V}_{\mathrm{O}_{2}}(\mathrm{mV})=103 \log \frac{\left(\overline{\mathrm{P}}_{\mathrm{O}_{2}}\right)_{2}}{\left(\overline{\mathrm{P}}_{\left.\mathrm{O}_{2}\right)_{1}}\right.}
$$

where $\left(\overline{\mathrm{P}}_{\mathrm{O}_{2}}\right)_{1}$ and $\left(\overline{\mathrm{P}}_{\mathrm{O}_{2}}\right)_{2}$ are average oxygen partial pressures at the cathode.

Fuel. Because the phosphoric acid fuel cell anode reaction is essentially reversible, the effects of fuel composition and utilization are less critical to cell performance. The available data concerning the effects of fuel composition are more difficult to interpret because of the poisoning effect of carbon monoxide, which is contained in virtually all gaseous fuel cell feeds derived from hydrocarbon (liquid or coal) feedstocks. The cell performance change with respect to hydrogen partial pressure is derived 


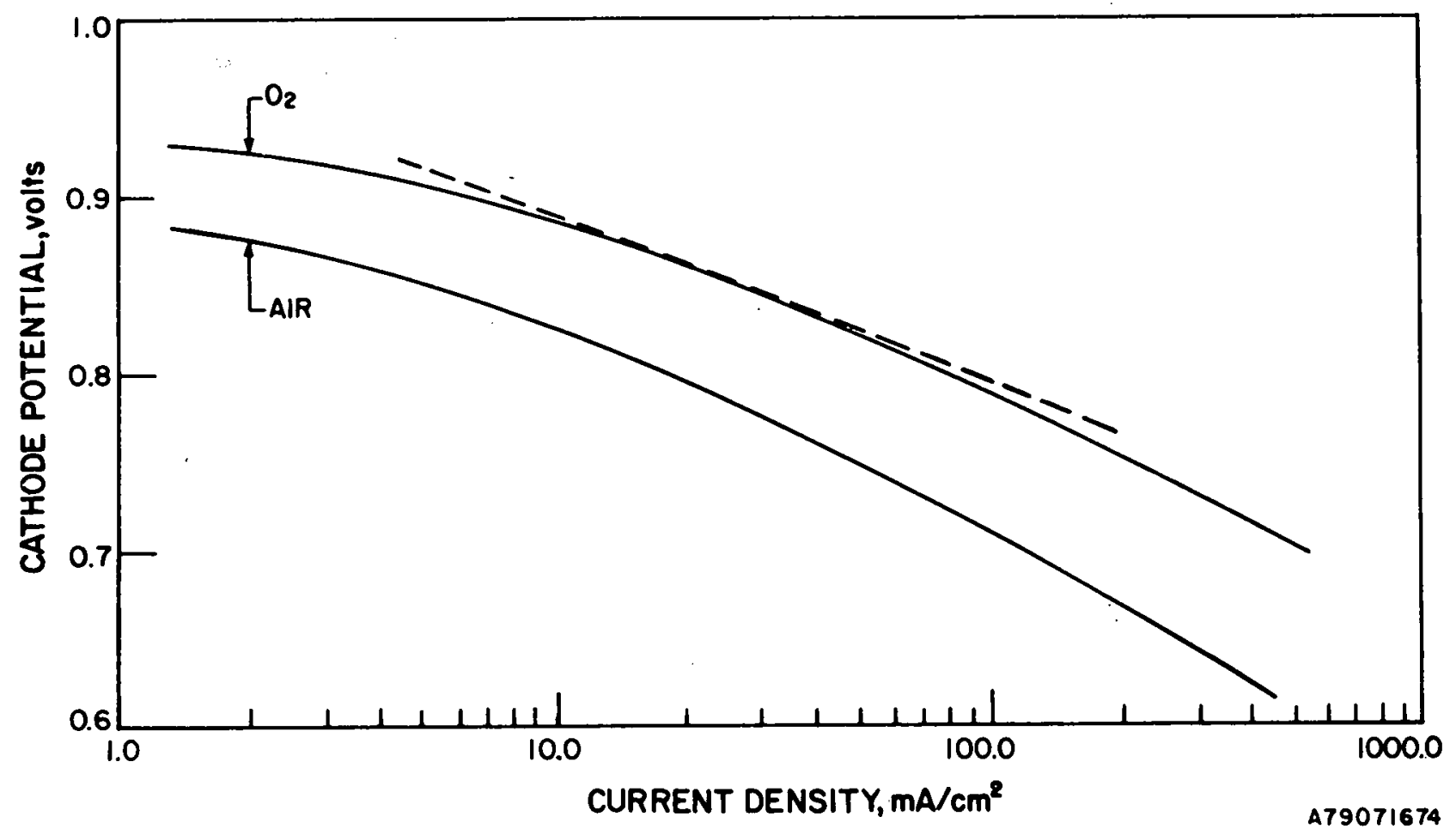

Figure 3.14. EFFECTS OF OXYGEN PARTIAL PRESSURE ON CATHODE PERFORMANCE AT $192^{\circ} \mathrm{C}, 100 \% \mathrm{H}_{3} \mathrm{PO}_{4}{ }^{20}$ (Reprinted with permission from Electrochimica Acta 23 , Kunz, H. R. and Gruver, G. A., "The Effect of Electrolyte Concentration on the Catalytic Activity of Platinum for Electrochemical Oxygen Reduction in Phosphoric Acid," Copyright 1978, Pergamon Press, Ltd.)

from the data in Figure $3.13:^{*}$

$$
\Delta \mathrm{V}_{\mathrm{H}_{2}}(\mathrm{mV})=77 \log \frac{\left(\overline{\mathrm{P}}_{\mathrm{H}_{2}}\right)_{2}}{\left(\overline{\mathrm{P}}_{\mathrm{H}_{2}}\right)_{1}}
$$

The hydrogen partial pressures are average values at the anode.

The loss in cell performance with hydrogen utilization has been demonstrated qualitatively on early electrodes, ${ }^{29}$ and on current electrodes, a 40-mV Nernst loss has been observed at $80 \%$ fuel utilization. 18

* The derivation of Equation 3.12 involved the application of Equations 3.14 and 3.18. These equations account for the voltage losses resulting from carbon monoxide and internal resistance, respectively. 
The previous discussion implies that fuel cells should be operated at low conversions to achieve high performance. However, lower conversions result in lower cell current efficiency. (See Chapter 5.) A compromise is required, and present utilizations are on the order of $85 \%$ fuel and $70 \%$ oxidant.

Effect of Impurities. This section will attempt to quantify the effects of various impurities on cell performance and electrolyte stability. Synergistic effects of more than one poison will not be considered in detail although such effects are important.

Carbon Compounds. Anode feeds derived from hydrocarbons will contain varying amounts of methane, carbon dioxide and carbon monoxide depending upon the fuel processing techniques used. Carbon dioxide is inert in the phosphoric acid fuel cell acting as a diluent. ${ }^{16}$

The poisoning of $\mathrm{Pt}$ by $\mathrm{CO}$, illustrated in Figure 3.11, is believed to be a simple site-elimination mechanism $13,22,30,32$ and results in decreased $\mathrm{Pt}$ activity at the anode, leading to increased anode polarization. The deleterious nature of carbon monoxide is described by Figure $3.15,13$ which also shows that raising the temperature decreased $C O$ poisoning.

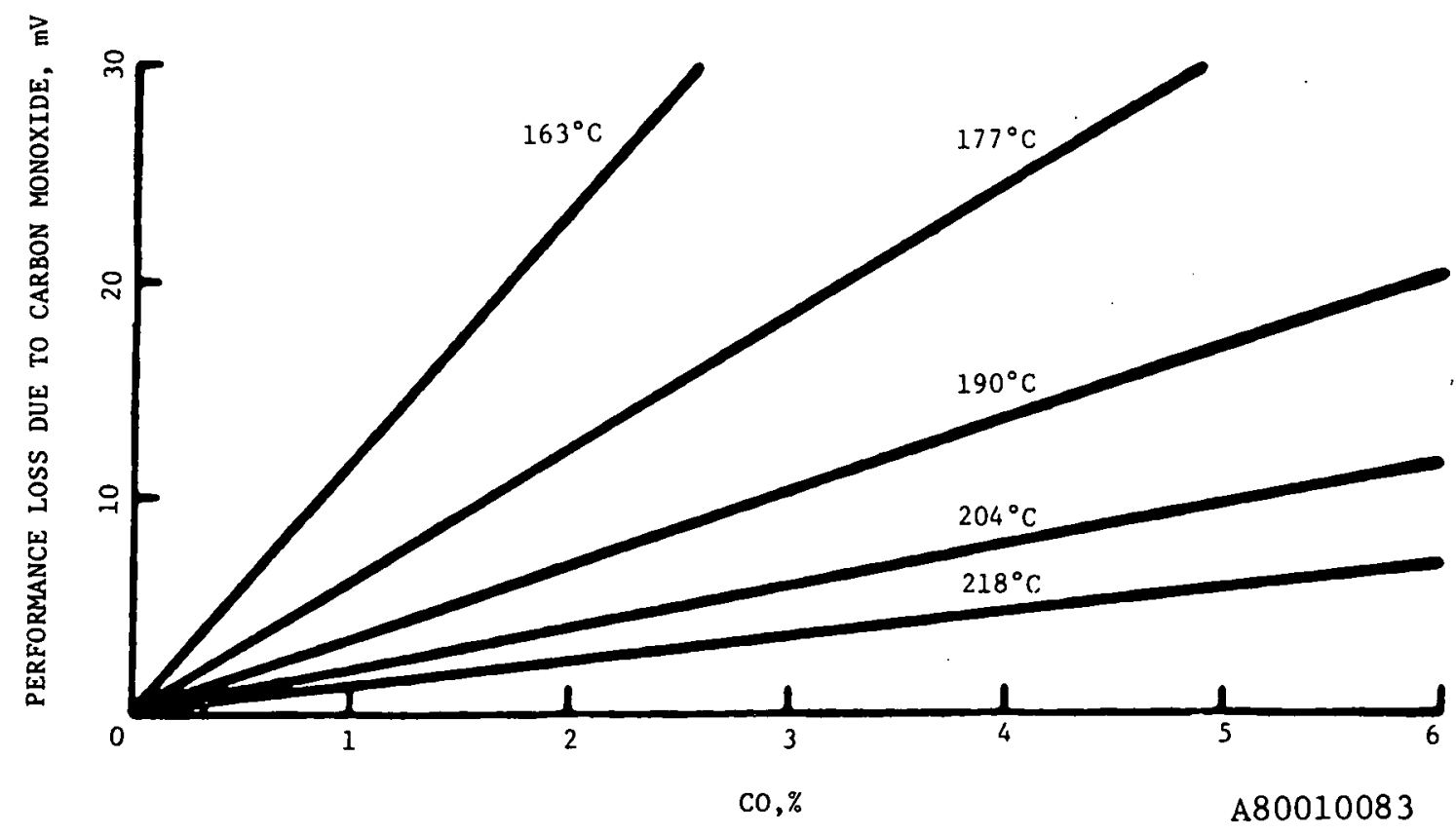

Figure 3.15. EFFECT OF CO CONTENT AND TEMPERATURE ON ANODE PERFORMANCE; $0.35 \mathrm{mg} \mathrm{Pt} / \mathrm{cm}^{2}, 269 \mathrm{~mA} / \mathrm{cm}^{2} 13$ 
The data of Figure 3.15 can also be represented as -

$$
\begin{gathered}
\Delta \mathrm{V}_{\mathrm{CO}}(\mathrm{mV})=-6.14\left((\mathrm{CO})_{2}-(\mathrm{CO})_{1}\right)(\%) \\
\Delta \mathrm{v}_{\mathrm{CO}}(\mathrm{mV})=-3.54\left((\mathrm{CO})_{2}-(\mathrm{CO})_{1}\right)(\%) \\
\Delta \mathrm{V}_{\mathrm{CO}}(\mathrm{mV})=-2.05\left((\mathrm{CO})_{2}-(\mathrm{CO})_{1}\right)(\%) \\
\Delta \mathrm{v}_{\mathrm{CO}}(\mathrm{mV})=-1.30\left((\mathrm{CO})_{2}-(\mathrm{CO})_{1}\right)(\%)
\end{gathered}
$$

The temperature-dependence of the effect of $\mathrm{CO}$ is shown graphically in Figure 3.16 .

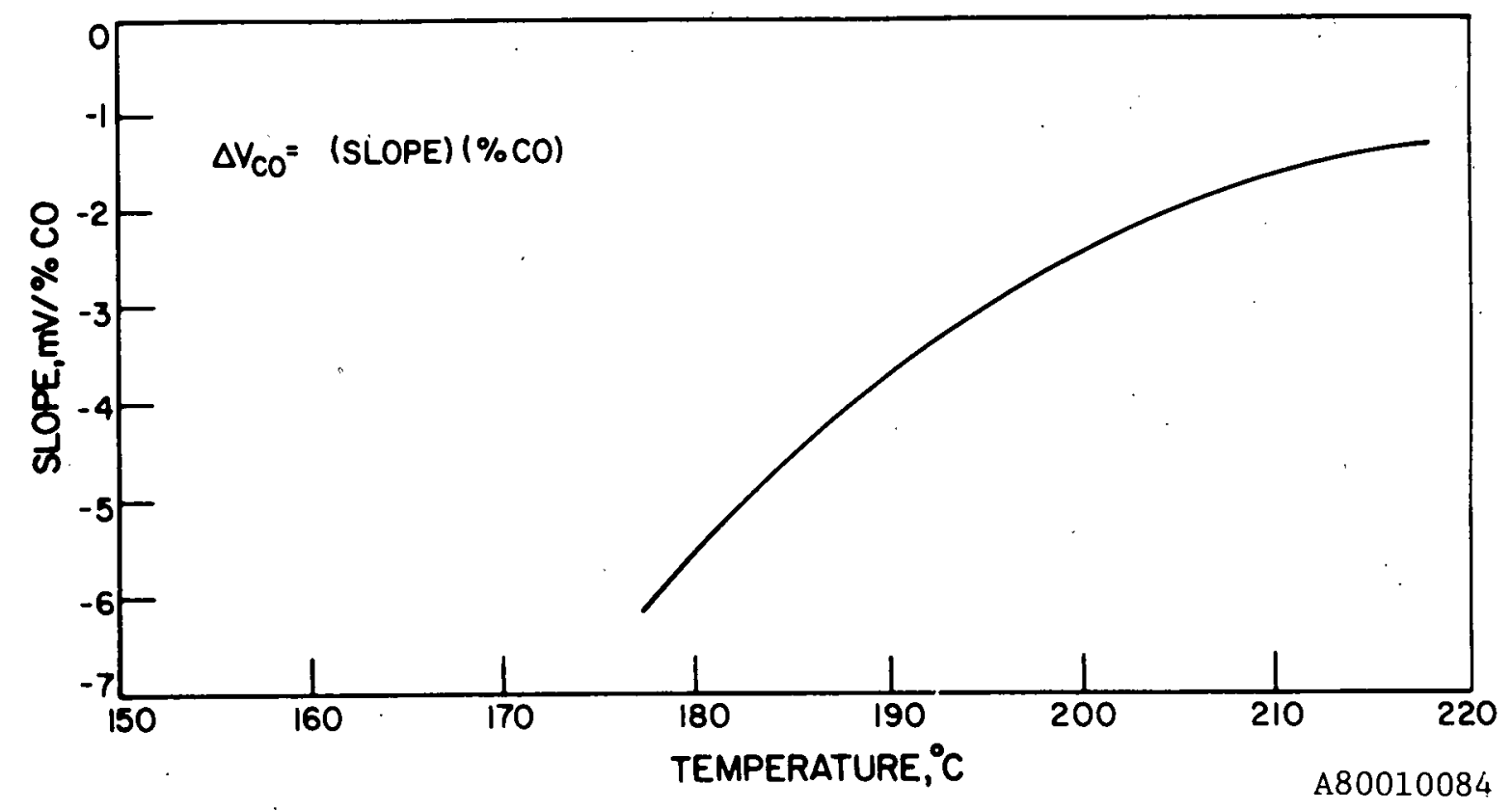

Figure 3.16. EFFECT OF TEMPERATURE ON SLOPE OF PERFORMANCE LOSS VS: CO CONCENTRATION

Sulfur Compounds. Advanced fuel processors operating on sulfurcontaining fuels will produce $\mathrm{H}_{2} \mathrm{~S}$ that will enter the anode if not first removed. The sulfur tolerance has been studied on a fuel cell running on simulated reformer effluent containing 130 to $200 \mathrm{ppm}_{2} \mathrm{~S}$, as shown in Figure $3.17 .^{33}$ The test was characterized by long periods of stable operation followed by rapid decay. The original performance could be restored by removing either $\mathrm{CO}$ or $\mathrm{H}_{2} \mathrm{~S}$ from the anode gas, indicating a synergistic effect, or by increasing the cell temperature from $375^{\circ}$ to $400^{\circ} \mathrm{F}$. The mechanism of $\mathrm{H}_{2} \mathrm{~S}-\mathrm{CO}$ poisoning is not well understood. Post-test analysis of electrodes from shorter term cells showed no observable changes attributable to exposure to $\mathrm{H}_{2} \mathrm{~S}$-containing anode gas. Work to broaden the understanding of the 


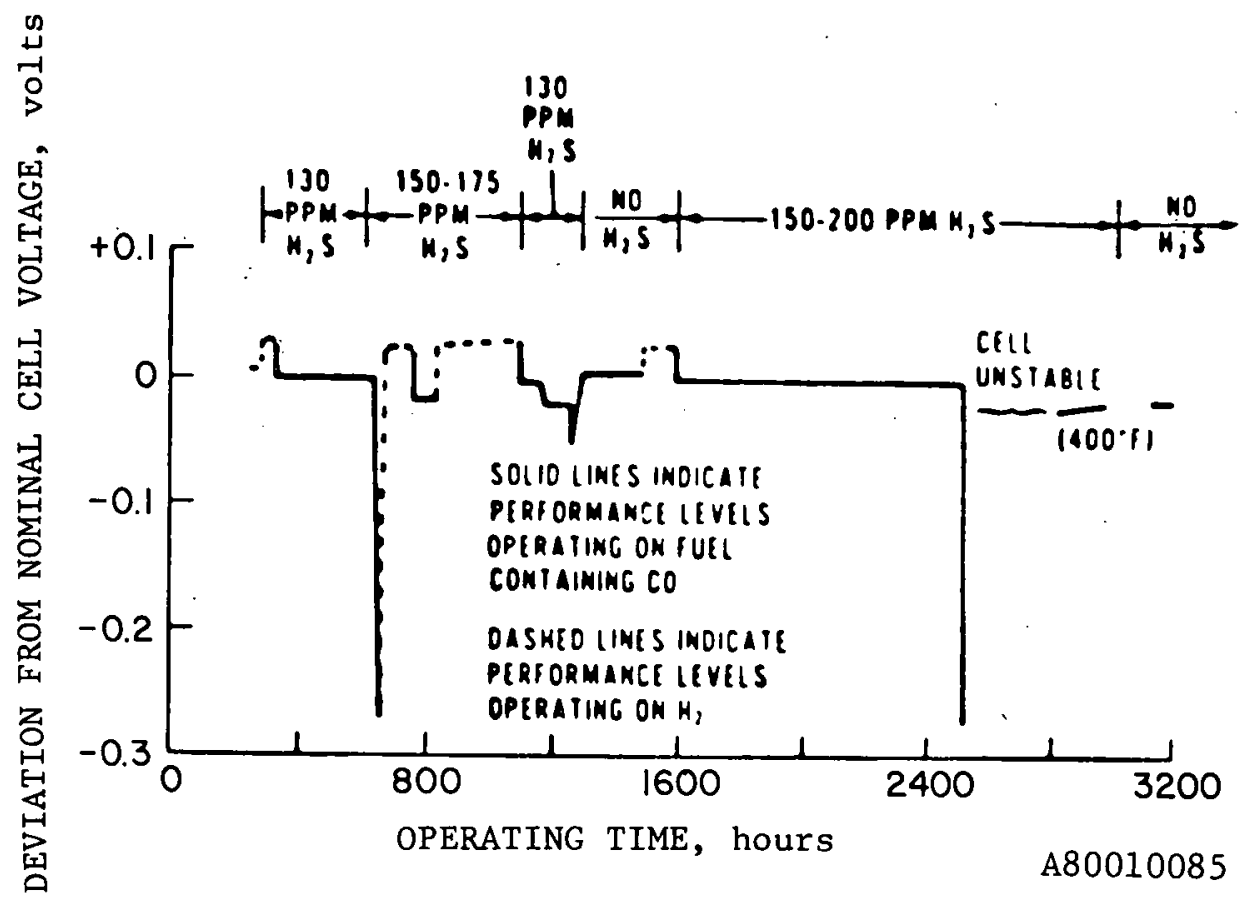

Figure 3.17. EFFECT OF $\mathrm{H}_{2} \mathrm{~S}$ ON PHOSPHORIC ACID FUEL CELL PERFORMANCE ${ }^{3}$

$\mathrm{CO}-\mathrm{H}_{2} \mathrm{~S}$ interaction in the phosphoric acid fuel cell is continuing.

Nitrogen Compounds. Nitrogen will be present at the cathode of an air-consuming fuel cell, and nitrogen-containing hydrocarbon feedstocks will introduce nitrogen compounds $\left(\mathrm{NH}_{3}, \mathrm{HCN}, \mathrm{NO}_{x}\right)$ into the anode. In addition, nitrogen compounds can result if nitrogen-free hydrocarbons are processed with air such as in autothermal reforming or coal gasification. The nitrogen in this case will be primarily molecular nitrogen, which acts as a diluent. Data on the interaction of nitrogen compounds other than ammonia have not been found in the literature.

Ammonia reacts with the phosphoric acid electrolyte to form ammonium dihydrogen phosphate (ADHP) according to -

$$
\mathrm{H}_{3} \mathrm{PO}_{4}+\mathrm{NH}_{3} \rightarrow\left(\mathrm{NH}_{4}\right) \mathrm{H}_{2} \mathrm{PO}_{4}
$$

The formation of the ADHP results in a performance loss, possibly by changing the conductivity of the acid $^{34}$ or by reducing the activity of the platinum by covering the active sites. ${ }^{35,36}$ The performance loss as a function of percent conversion of $\mathrm{H}_{3} \mathrm{PO}_{4}$ to ADHP is illustrated in Figure 3.18. Electrolyte conversion must be limited to less than about 0.2 mole percent to avoid unacceptable performance penalties. Diagnostic data on the cells of Figure 3.18 


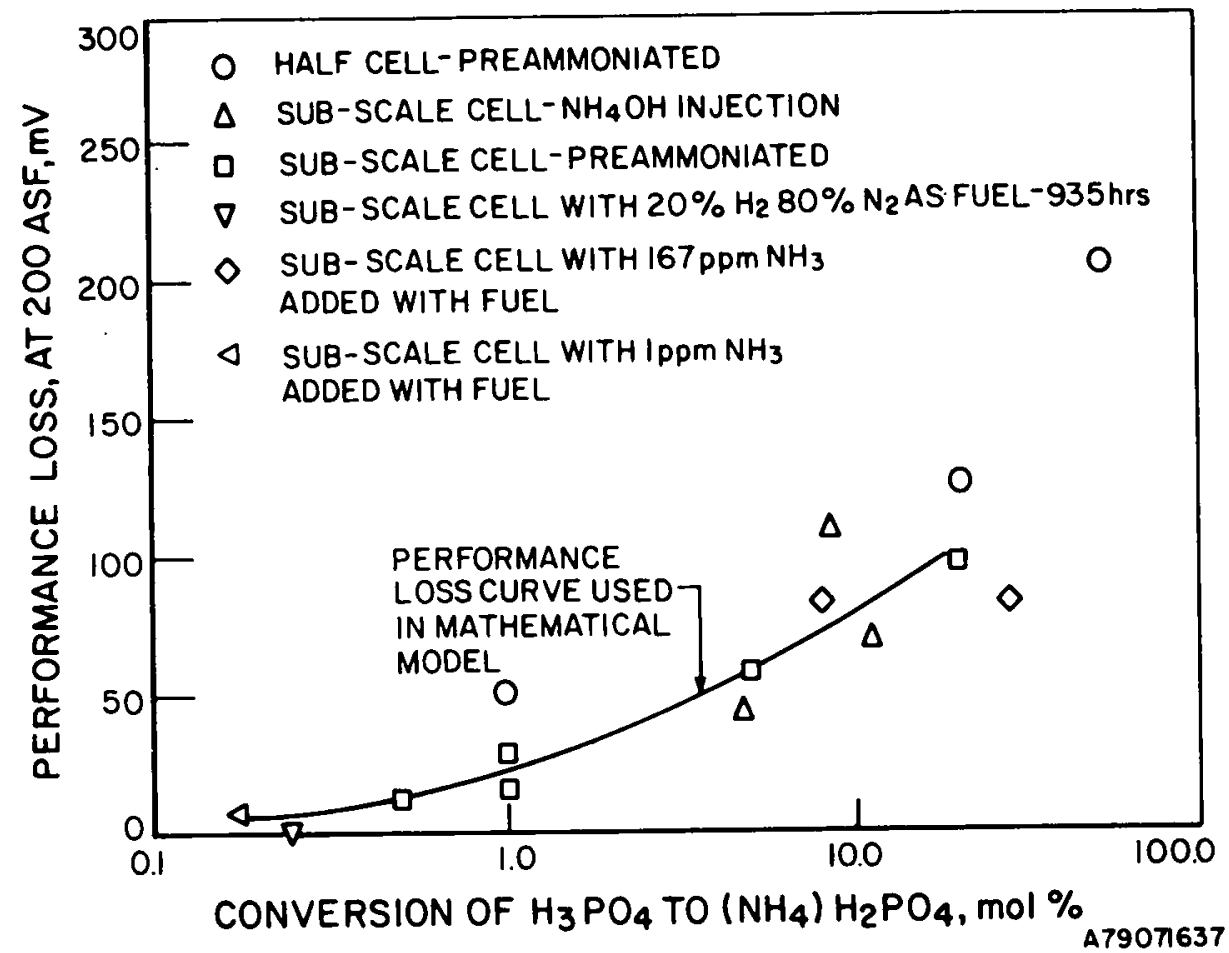

Figure 3.18. PERFORMANCE LOSS DUE TO AMMONIATION OF $\mathrm{H}_{3} \mathrm{PO}_{4}^{36}$

indicate that most of the performance loss occurred at the cathode. Figure 3.19 shows that $84 \%$ of the cathode activity is lost by only $1 \%$ conversion of the acid to ADHP.

Several long-term tests (up to 10,000 hours) have shown that the ADHP levels appear to reach a constant value significantly lower than predictions based on inlet ammonia concentrations. This observation, in conjunction with the fact that the performance was restored if the ammonia was removed from the feed (Figure 3.20), led to the hypothesis that the ammonium ion is oxidized at cell operating potential and temperature. Figure 3.21 confirms the ammonium ion oxidation premise by demonstrating the currents obtained at normal cell operating conditions.

Summary, Other Compounds. The foregoing considered the effect of carbon, sulfur, and nitrogen compounds on phosphoric acid fuel cell performance. Synergistic effects have not been discussed. Data for other possible impurities have not been reported but estimates of maximum allowable levels are summarized in Table 3.1. 


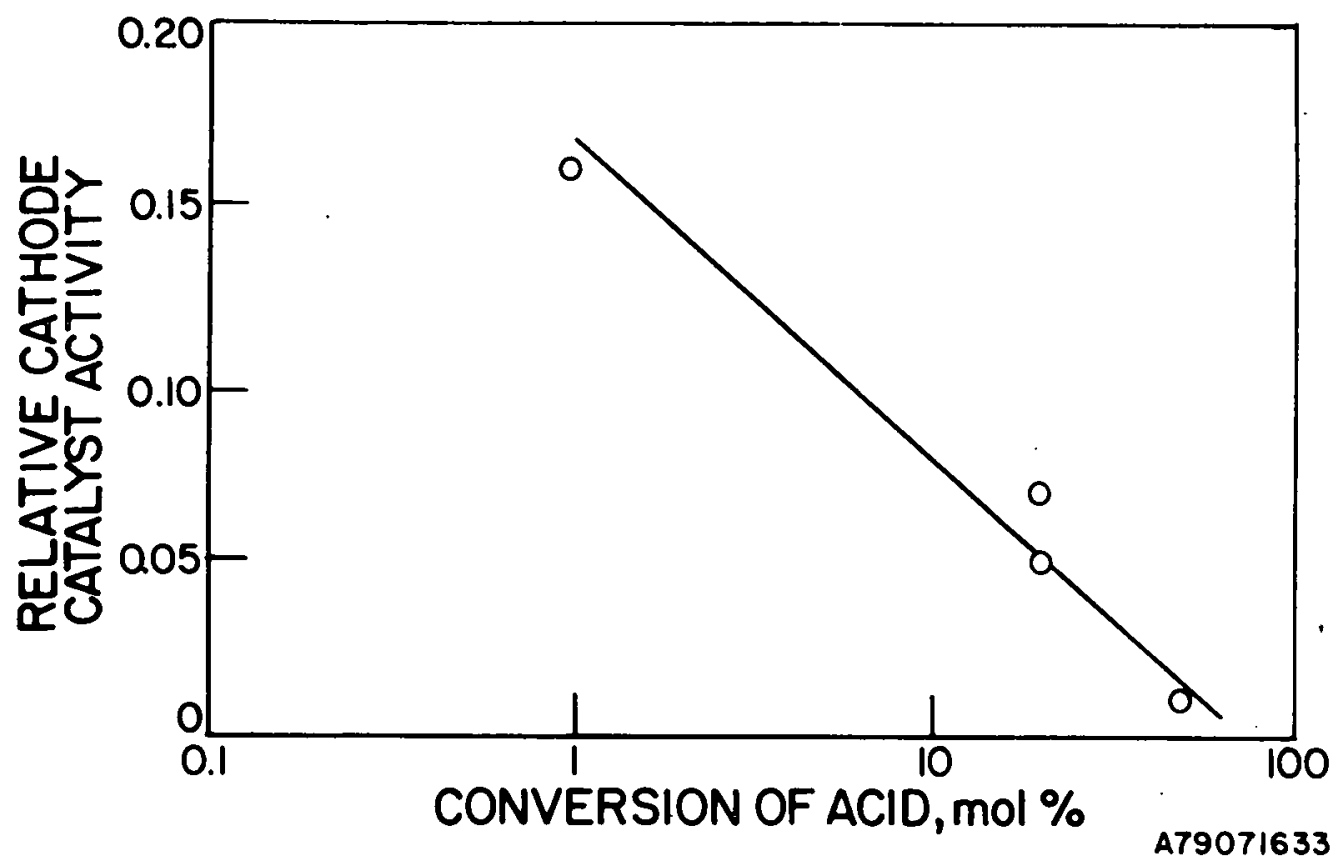

Figure 3.19. RELATIVE CATHODE CATALYST ACTIVITY AS A FUNCTION OF PERCENT $\mathrm{H}_{3} \mathrm{PO}_{4}$ CONVERSION TO $\left(\mathrm{NH}_{4}\right) \mathrm{H}_{2} \mathrm{PO}_{4}{ }^{36}$

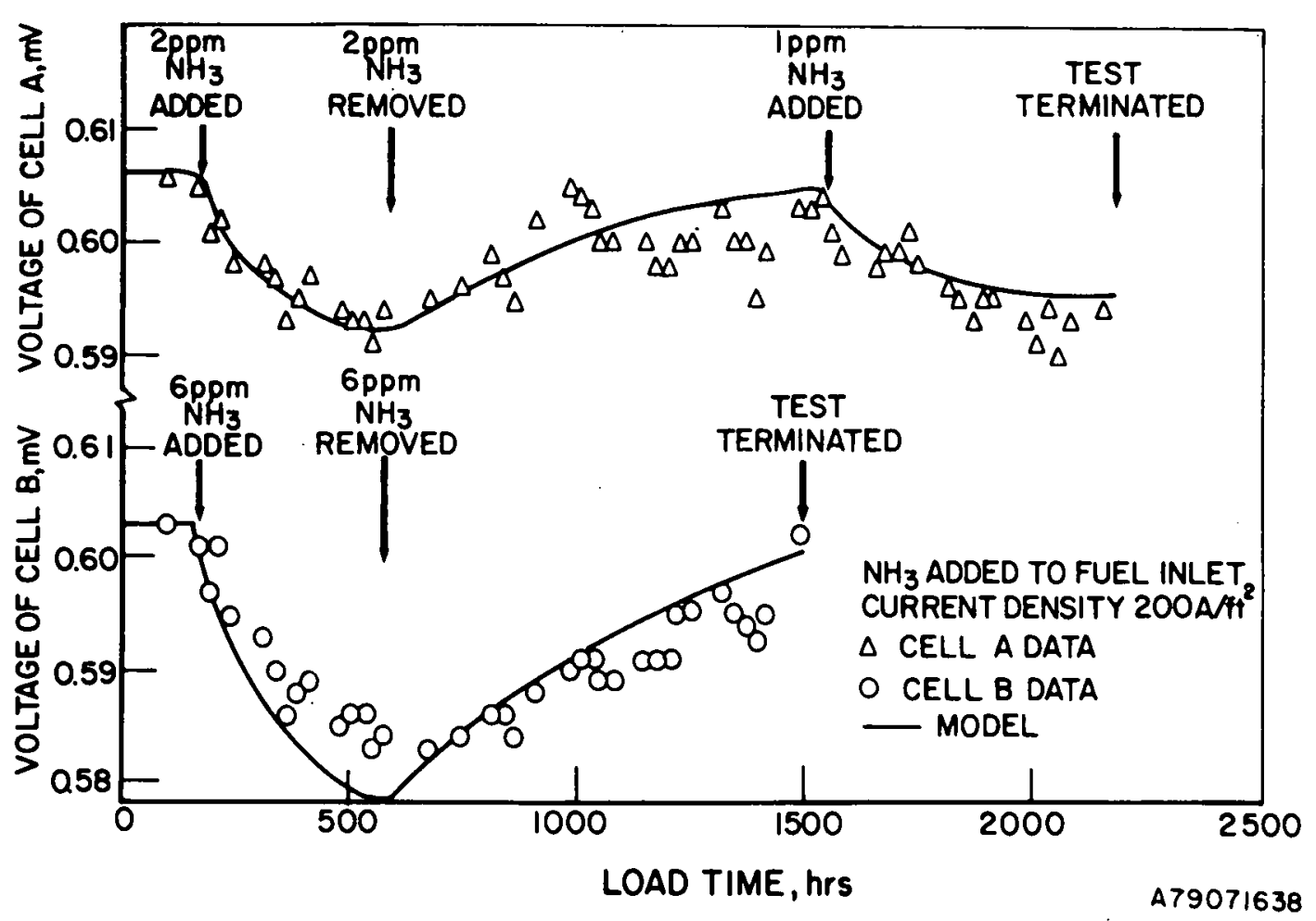

Figure 3.20. CELL ENDURANCE IN THE PRESENCE OF AMMONIA ${ }^{36}$ 


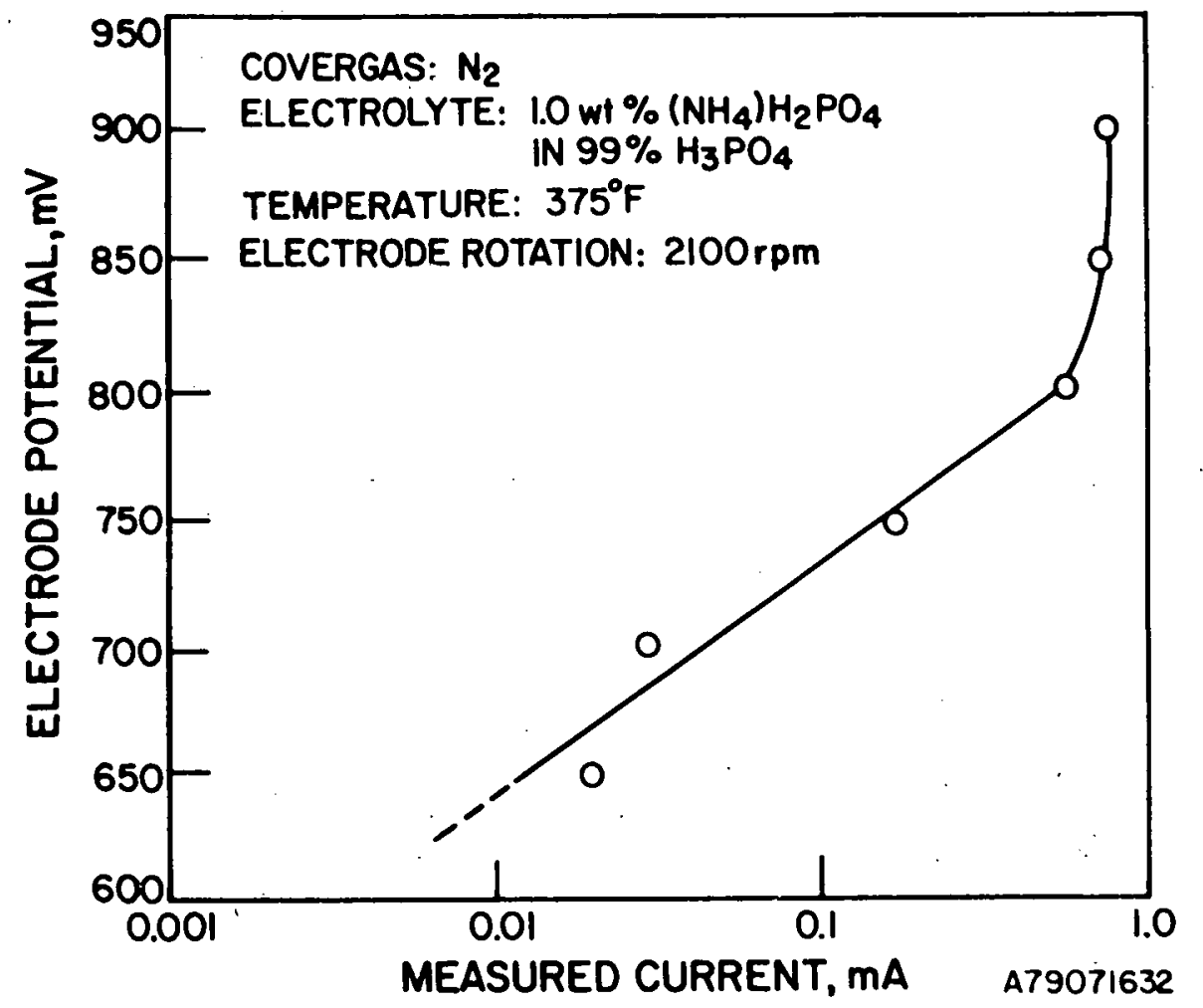

Figure 3.21. POTENTIAL VS. AMMONIUM PHOSPHATE OXIDATION CURRENT ${ }^{36}$

Table 3:1. ESTTMATED MAXIMUM ALLOWABLE IMPURITY LEVELS PHOSPHORIC ACID FUEL CELLS 16,37

$\frac{\text { Impurity }}{\mathrm{CO}_{2}}$
$\mathrm{CH}_{4}$
$\mathrm{~N}_{2}$
$\mathrm{Co}$
$\mathrm{H}_{2} \mathrm{~S}, \mathrm{COS}$
$\mathrm{C}_{2}{ }^{+}$
$\mathrm{Cl}^{-}$
$\mathrm{NH}_{3}$
Metal ions (Fe, Cu, etc.)

$\underline{\text { Maximum Limit }}$

diluent
diluent
diluent
Figure 3.11
$100 \mathrm{ppm}$
$100 \mathrm{ppm}$
$1 \mathrm{ppm}$
$1 \mathrm{ppm}$
nil

44

INSTITUTE. OF G G A S T T T C H N O L O G Y 
Effect of Internal Resistance. The obtainable cell voltage is reduced by resistance to ionic conduction in the electrolyte and electronic conduction in the electrodes, current collectors, and interfaces. The magnitude of this loss is $15-20 \mathrm{mV} /\left(100 \mathrm{~mA} / \mathrm{cm}^{2}\right) .16$ The sample calculations at the end of this chapter will use -

$$
\Delta V_{i R}(\mathrm{mV})=-0.20 \mathrm{i}\left(\mathrm{mA} / \mathrm{cm}^{2}\right)
$$

\section{Sample Calculations}

This section will use the data and equations summarized in Table 3.2 to estimate the 4.8-MW phosphoric acid fuel cell power plant performance. The operating conditions for the baseline phosphoric acid fuel cell performance (Figure 3.9) differ from the approximate conditions of the 4.8-MW power plant operating on reformed natural gas (RNG) at $323 \mathrm{~mA} / \mathrm{cm}^{2}$ as shown in Table 3.3.

Tab1e 3.2. SUMMARY OF PARAMET́RIC DESIGN EQUATIONS FOR PHOSPHORIC ACID FUEL CELL

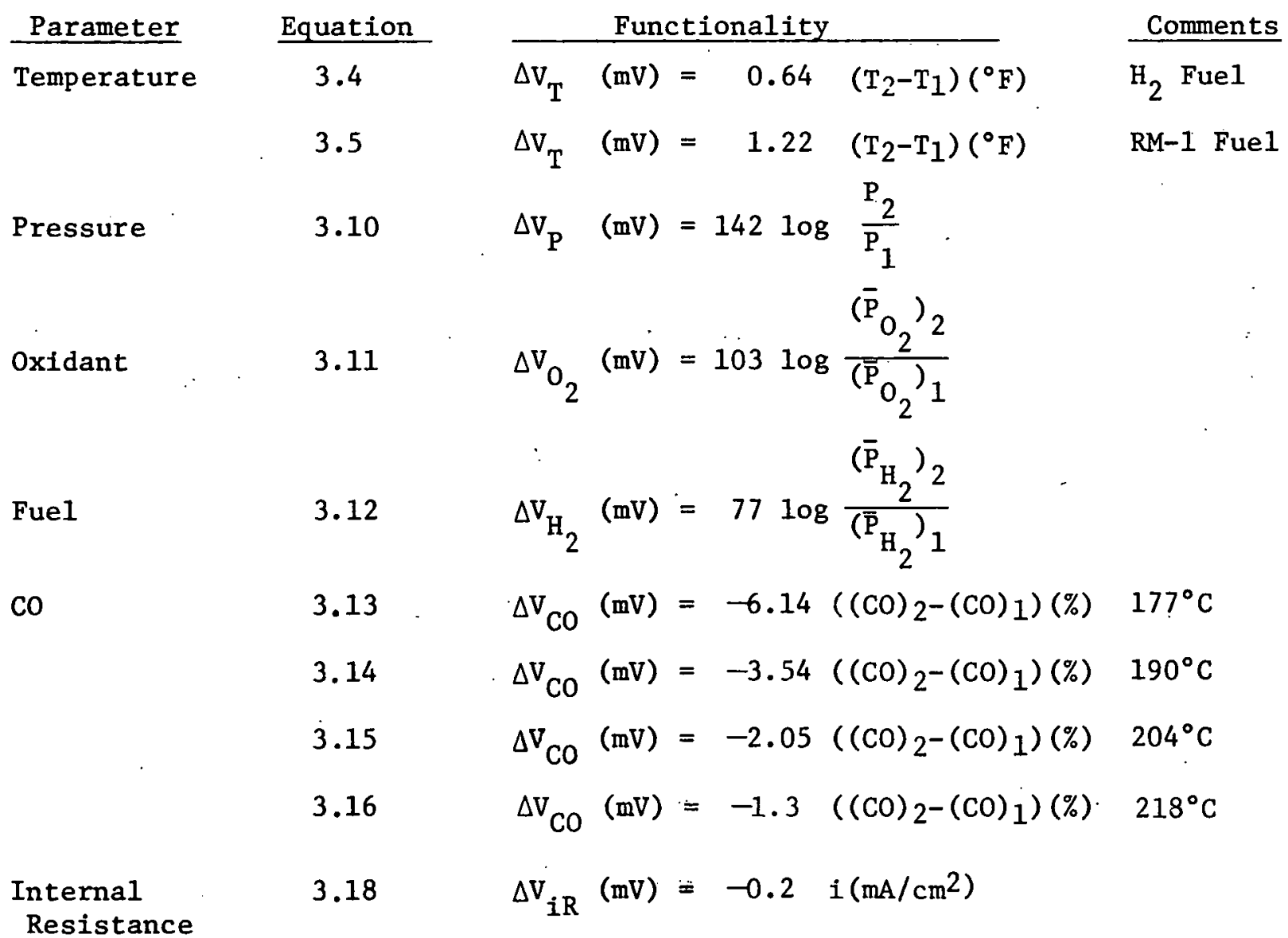


Table 3.3. COMPARISON OF BASELINE AND PROJECTED 4.8-MW PERFORMANCE AND EFFECT OF CONTRIBUTING FACTORS

\begin{tabular}{|c|c|c|c|}
\hline Operating Variable & Baseline & $4.8 \mathrm{MW}$ & $\Delta \mathrm{V}(\mathrm{mV})$ \\
\hline Temperature, ${ }^{\circ} \mathrm{C}$ & 175 & 190 & +32.9 \\
\hline Pressure, psia & 14.7 & 50 & +75.5 \\
\hline $\begin{array}{l}\text { Oxidant } \\
\quad \text { Composition, } \% \mathrm{O}_{2} \\
\text { Utilization, } \%\end{array}$ & $\begin{array}{r}100 \\
\sim 0\end{array}$ & $\begin{array}{l}21 \text { (air) } \\
70\end{array}$ & -92.3 \\
\hline $\begin{array}{l}\text { Fue } 1 \\
\quad \text { Composition, } \% \mathrm{H}_{2} \\
\text { Utilization }\end{array}$ & $\begin{array}{r}100 \\
20\end{array}$ & $\begin{array}{l}64(\mathrm{RM}-1) \\
85\end{array}$ & -22.8 \\
\hline $\begin{array}{l}\text { Impurities, \% } \\
\text { CO } \\
\mathrm{CO}_{2}\end{array}$ & $\begin{array}{l}0 \\
0\end{array}$ & $\begin{array}{r}1.4 \\
18.3\end{array}$ & $\begin{array}{c}-8.6 \\
*\end{array}$ \\
\hline $\begin{array}{l}\text { Internal Reß̧istance, } \\
\mathrm{mV} /\left(\mathrm{mA} / \mathrm{cm}^{2}\right)\end{array}$ & -0.2 & -0.2 & 0 \\
\hline Net Change, mV & & & -15.3 \\
\hline
\end{tabular}

Pressure. Use Figures 3.12 and 3.13 and Equation 3.10:

$$
\begin{aligned}
& \Delta V_{P}(\mathrm{mV})=142 \log \frac{50}{14.7} \\
& \Delta V_{P}=+75.5 \mathrm{mV}
\end{aligned}
$$

Temperature. As mentioned previously, the operating temperature affects the allowable level of $\mathrm{CO}$ in the fuel. These two operating variables will be considered together. Their combined effect will be determined by two alternative paths yielding the same results:

A. The first path reduces the $175^{\circ} \mathrm{C}$ performance because of the presence of $1.4 \%$ CO by Equation 3.13:

$$
\begin{aligned}
\Delta \mathrm{V}_{\mathrm{CO}}(\mathrm{mV}) & =-6.14 \mathrm{mV} \quad(1.4) \\
\Delta \mathrm{V}_{\mathrm{CO}} & =-8.6 \mathrm{mV}
\end{aligned}
$$

Then the temperature is increased through Equation 3.5, which includes the diminishing effect of $\mathrm{CO}$ :

$$
\begin{array}{ll}
\Delta \mathrm{V}_{\mathrm{T}}(\mathrm{mV}) & =(1.22)(190-175)(9 / 5) \\
\Delta \mathrm{V}_{\mathrm{T}} & =+32.9 \mathrm{mV}
\end{array}
$$


The net effect is - $\ldots$

$$
\Delta \mathrm{V}_{\mathrm{T}, \mathrm{CO}}=32.9-8.6=+24.3 \mathrm{mV}
$$

B. The alternative approach evaluates the difference in loss caused by

the presence of $1.4 \% \mathrm{CO}$ at the different temperatures and then raises

the temperature of the clean fuel cell:

$\Delta \mathrm{V}_{\mathrm{CO}}=-8.6 \mathrm{mV}$ at $175^{\circ} \mathrm{C}$

$\Delta \mathrm{V}_{\mathrm{CO}}=-5.0 \mathrm{mV}$ at $190^{\circ} \mathrm{C}$

Therefore, there is a net gain in performance of $3.6 \mathrm{mV}$.

The temperature gain is -

$\Delta \mathrm{V}_{\mathrm{T}}=0.64$ (15) $9 / 5=+17.3 \mathrm{mV}$

And the total gain is -

$\Delta \mathrm{V}_{\mathrm{T}, \mathrm{CO}}=17.3+3.6=+20.9 \mathrm{mV}$

Oxidant. The 4.8-MW fuel cell power plant will operate on air $\left(21 \% 0_{2}\right)$ at $70 \%$ oxygen utilization. Because most of the product water is removed at the cathode, the oxygen is diluted by 2 moles of $\mathrm{H}_{2} \mathrm{O}$ for every mole of oxygen consumed. The inlet, exit, and average compositions are summarized in Table 3.4 .

Table 3.4. COMPOSITION PROFILE OF OXIDANT AT $70 \%$ UTILIZATION

$\begin{array}{llll}\mathrm{N}_{2}, \text { mol } & \frac{\text { Inlet }}{0.79} & \frac{\text { Exit }}{0.79} & \frac{\text { Average }}{0.79} \\ \mathrm{O}_{2}, \text { mol } & 0.21 & 0.063 & 0.1365 \\ \mathrm{H}_{2} \mathrm{O}, \text { mol } & 0 & 0.294 & 0.147 \\ \text { Total mol } & 1.0 & 1.147 & 1.0735 \\ \left(\mathrm{P}_{\mathrm{O}_{2}}{ }^{2}\right. & 0.21 & 0.055 & 0.127\end{array}$

The baseline case is for oxygen at low utilization so $\left(\bar{F}_{0_{2}}\right)_{1}=1.0$. The loss because of the lower inlet oxygen concentration and high oxygen utilization is determined by Equation 3.11:

$\mathrm{v}_{0_{2}}=103 \log \frac{0.127}{1.00}=-92.3 \mathrm{mV}$.

Fuel. The baseline cell operates on hydrogen at low utilization 
so $\left(\overline{\mathrm{P}}_{\mathrm{H}_{2}}\right)_{1}=1.0$. In contrast, the $4.8-\mathrm{MW}$ fuel cell power plant operates on $64 \%$ hydrogen at $85 \%$ utilization.

The composition profile is summarized in Table 3.5 .

Table 3.5. ĊOMPOSITON PROFILE OF FUEL AT 85\% UTILIZATION

$\begin{array}{lrlll}\mathrm{H}_{2}, \text { mol } & \frac{\text { Inlet }}{} & & \text { Exit } & \text { Average } \\ \text { Diluents, mol } & 0.64 & 0.096 & 0.368 \\ \text { Total mol } & 0.36 & 0.36 & 0.36 \\ \left(\mathrm{P}_{\mathrm{H}_{2}}\right)^{2} & 1.00 & 0.456 & 0.728 \\ & 0.64 & 0.211 & 0.505\end{array}$

Therefore, from Equation 3.12 -

$\Delta \mathrm{V}_{\mathrm{H}_{2}}=77 \log \frac{0.505}{1.00}=-22.8 \mathrm{mV}$

Design Considerations. Analysis of the calculations shows that the increases obtained by increasing temperature and pressure are offset by using dilute oxidant and fuel gases at high utilizations and by the presence of $\mathrm{CO}$ in the fuel. The net effect is $-15.3 \mathrm{mV}$, which indicates that the 4.8-MW fuel cell will operate at about the same level as the baseline $\mathrm{H}_{2}-\mathrm{O}_{2}$ fuel cell.

Further inspection reveals that the major loss is a result of the of air at high conversion. If the air utilization was decreased to $50 \%$ by pumping more air through the cathode, approximately $7 \mathrm{mV}$ would be gained. The gain could be translated into an increase in current density to reduce capital costs or into an improvement in efficiency. However, the decreased oxidant utilization requires the pumping of additional air. The resolution of this question is not within the scope of this work, but the parametric performance equations will aid the systems engineer in tackling similar problems. 
1. Kordesch, K. V., "25 Years of Fuel Cell Development," J. Electrochem. Soc. 125, 77C-91C (1978) March.

2. Fickett, A. P., "Fuel Cell Electrocatalysis: Where Have We Failed?" in Proceedings of the Symposium on Electrode Materials and Processes for Energy Conversion and Storage, Vol. $17-6,546$ (1977).

3. Williams, K. R., Ed., An Introduction to Fuel Cells. New York: Elsevier, 1977.

4. McDouga11, A., Fuel Cells. New York: John Wiley, 1976.

5. Bolan, P., "Heat Pumps and Fuel Cells." Paper presented at the 69th Annual Meeting of the American Institute of Chemical Engineers, Chicago, November 27-December 4, 1976.

6. Energy Research Corporation, "Fuel Cell Stacks," USAMERADCOM Report, Contract No. DAAK02-74-C-0367. Danbury, Conn., 1977.

7. Maru, H. C. and Baker, B. S., "Status of ERC's Phosphoric Acid Fuel Ce11 Technology." Paper presented at the Fuel Cell Workshop, Sarasota, Fla., November 14-17, 1977.

8. Kurpit, S. S. and Gillis, E. A., "Methanol Fuel for Fuel Cells," in Proceedings of the Engineering Foundation Conference on Methanol, Henniker, N. H., July, 1974.

9. Kurpit,. S. S., " 1.5 and $3 \mathrm{~kW}$ Indirect Methanol-Air Fuel Cell Power Plants." Paper presented at the 10th Intersociety Energy Conversion Engineering Conference, Newark, De1., August 18-22, 1975.

10. Onischak, M. and Kurpit, S. S., "1.5 kW Indirect Methano1-Air Fuel Cel1 Power Plant Advanced Development Mode1," in the 27th Power Sources Symposium Record, 1976.

11. Noyes, R., Ed., Fuel Cells for Public Utility and Industrial Power. Park Ridge, N. J.: Noyes Data Corporation, 1977.

12. Handley, L. M., "Status of 40-kW and 4.8-MW Fuel Cell Programs." Paper presented at National Fuel Cell Seminar, San Francisco, July 11-13, 1978.

13. Kunz, H. R., "The State-of-the-Art Hydrogen-Air Phosphoric Acid Electrolyte Fuel Cells," in Proceedings of the Symposium on Electrode Materials and Processes for Energy Conversion and Storage, Vol. 77-6, 607 (1977).

14. United Technologies Corporation, "Demonstrator Power Plant Model Specification," FCS-0493, Contract No. EX-76-C-01-2102. . South .Windsor, Conn., March, 1978.

15. Balzhiser, R. E., "R\&D Status Report: Fossil Fuel and Advanced Systems Division," EPRI J., 34-41 (1978) June. 
16. Gillis, E. A., Electric Power Research Institute, letter of January 3, 1979.

17. Giner, J. and Hunter, C., "The Mechanism of Operation of the Teflon-Bonded Gas Diffusion Electrode: A Mathematical Mode1," J. Electrochem. Soc. 116, 1124-1130 (1969) August.

18. Maru, H. C. and Christner, L. C., "Phosphoric Acid Fuel Cell Cathode." Paper presented at National Fuel Cell Seminar, San Francisco, July 11-13, 1978 .

19. Energy Research Corporation, "Electrode Optimization for Phosphoric Acid Fuel Ce11," DOE Report, Contract No. ET-78-C-03-1873. Danbury, Conn., 1978 .

20. Kunz, H. R. and Gruver, G. A., "The Effect of Electrolyte Concentration on the Catalytic Activity of Platinum for Electrochemical 0rygen Reduction in Phosphoric Acid," Electrochim. Acta. 23, 219 (1978) March.

21. Appleby, A. J., "Oxygen Reduction on Oxide-Free Platinum in $85 \%$ Orthophosphoric Acid: Temperature and Impurity Dependence," J. Electrochem. Soc. 117, 328 (1970) March.

22. Stonehart, P. and Ross, P. N., Jr., "The Use of Porous Electrodes to Obtain Kinetic Rate Constants for Rapid Reactions and Adsorption Isotherms of Adsorbed Poisons," Electrochim Acta. 21, 441 (1976) June.

23. Kunz, H. R. and Gruver, G. A., "The Catalytic Activity of Platinum Supported on Carbon for Electrochemical Oxygen Reduction in Phosphoric Acid," J. Electrochem. Soc. 122, 1279 (1975) October.

24. Voge1, W. M. and Lundquist, J. T., "Reduction of Oxygen on Teflon-Bonded Platinum Electrodes," J. Electrochem. Soc. 117, 1512 (1970) December.

25. Johnson, W. H., "Phosphoric Acid Technology Improvement Program." Paper presented at National Fuel Cell Seminar, San Francisco, July 11-13, 1978.

26. Johnson, W. H., "Improvement of Fuel Cell Technology Base," UTC Technical Progress Report FCR-1809, Contract No. ET-76-C-03-1169. South Windsor, Conn., April, 1978.

27. Maru, H. C., Patel, D., Scozzafava, J. and Abens, S., "Pressurization of Phosphoric Acid Fuel Cell." Paper presented at Pittsburgh Electrochemical Society Meeting, Pittsburgh, October, 1978.

28. Voge1, W., Lundquist, J. and Bradford, A., "Reduction of Oxygen on Teflon-Backed Platinum Black Electrodes," Electrochtm. Acta. 17, 1735-1744 (1972) October.

29. Energy Research Corporation, "Low-Cost Acid Fuel Cel1 Stacks," USAMERADCOM Report, Contract No. DAAK-02-67-0063. Danbury, Conn., 1968. 
30. Breiter, M. W., "Effect of Chemisorbed Carbon Monoxide on Hydrogen Adsorption at Platinum Electrodes." Paper presented at 145th Electrochemical Society Meeting, San Francisco, May 12-17, 1974.

31. Kohlmayr, G. and Stonehart, P., "Adsorption Kinetics for Carbon Monoxide on Platinum in Hot Phosphoric Acid," Electrochim. Acta. 18, 211 (1973) February.

32. Vogel, W., Lundquist, J., Ross, P., Jr. and Stonehart, P., "Reaction Pathways and Poisons - II: The Rate Controlling Step for Electrochemical Oxidation of Hydrogen on Pt in Acid and Poisoning of the Reaction by CO," Electrochim. Acta. 20, 79-93 (1975) January.

33. United Technologies Corporation, "Advanced Technology Fuel Cell Program;" EPRI Report EM-576. South Windsor, Conn., 1977.

34. Baris, J. M., Pratt and Whitney Aircraft, telephone conversation of July 12, 1978.

35. Szymanski, S. T., United Technologies Corporation, telephone conversation of July 14, 1978 .

36. Szymanski, S. T., Gruver, G. A., Katz, M. and Kunz, H. R., "Effect of Ammonia on Hydrogen-Air Phosphoric Acid Cell Performance." Paper presented at Electrochemical Society Meeting, Pittsburgh, October 1978.

37. United Technologies Corporation, "Advanced Technology Fuel Cell Program," EPRI Report EM-335. South Windsor, Conn., 1976. 
Chapter 4. MOLTEN CARBONATE FUEL CELLS

\section{Introduction}

The molten carbonate fuel cell history has been presented in a number of sources ${ }^{1-3}$ so only the significant advances of the last 10 years, shown in Figure 4.1, will be discussed. ${ }^{4}$

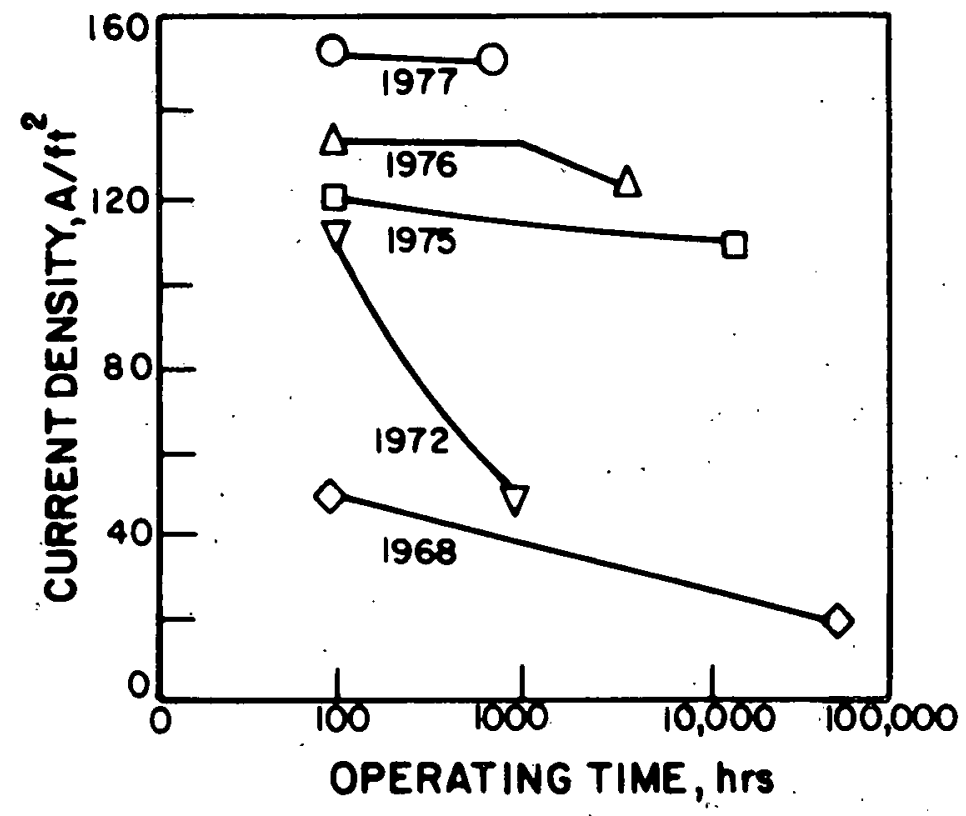

$\triangle 79092008$

FIgure 4.1. MOLTEN CARBONATE PERFORMANCE HISTORY

ON RNG FUEL AT DESIGN VOLTAGE REQUIRED TO

ACHIEVE $7500 \mathrm{Btu} / \mathrm{kWh}$ r HEAT RATE ${ }^{4}$

1. From 1968 to 1972 the electrolyte was changed from a ternary $\left(\mathrm{Li}_{2} \mathrm{CO}_{3} / \mathrm{K}_{2} \mathrm{CO}_{3} / \mathrm{Na}_{2} \mathrm{CO}_{3}\right)$ to a binary $\left(\mathrm{Li}_{2} \mathrm{CO}_{3} / \mathrm{K}_{2} \mathrm{CO}_{3}\right)$ electrolyte, and higher surface area electrodes were used. These changes increased the initial performance, but rapid decay occurred because of sintering of the high surface area nickel anode.

2. The anode pore structure was stabilized by adding sintering inhibitors to the nickel (metals and metal oxides) to achieve the performance and endurance of the 1975 cell. This cell was thermally cycled without losing performance. Electrolyte was added to make up for evaporation, creepage, and corrosion losses, allowing operation of the cell for 15,000 hours. 
3. The increased performance of the 1976 cell was the result of refinement of the anode structure (mean pore size, thickness, porosity, pore size distribution, etc.). The change in the slope of the decay curve around 3000 hours is typical of cells without electrolyte addition. Many current cells have an electrolyte reservoir, eliminating the need for periodic addition of electrolyte.

4. The improved performance of the 1977 cell, which almost meets design goals, resulted from improving the nickel cathode structure and using thinner electrolyte tiles to reduce iR losses.

Binary eutectic cells operate at 650 to $700^{\circ} \mathrm{C}$; ternary eutectic systems can potentially operate at 500 to $550^{\circ} \mathrm{C}$. To achieve a $7500 \mathrm{Btu} / \mathrm{kWhr}$ heat rate, the Energy Conversion Alternatives Study (ECAS) ${ }^{5,6}$ has specified that a molten carbonate fuel cell, integrated with an air-blown coal gasifier having a product composition of 16 mole percent $\mathrm{H}_{2}, 21$ mole percent $\mathrm{CO}$, 9.5 mole percent $\mathrm{H}_{2} \mathrm{O}, 6$ mole percent $\mathrm{CO}_{2}$, and 46 mole percent $\mathrm{N}_{2}$, must have a design point of $150 \mathrm{~A} / \mathrm{ft}^{2}$ at 0.85 volts/cell (110 A/ft ${ }^{2}$ has been demonstrated).

Estimates show molten carbonate fuel cell systems are about $45 \%$ efficient when operating on petroleum liquids without a bottoming cycle ${ }^{7}$ and possibly over $90 \%$ efficient with cogeneration ${ }^{8}$. The oxidant gas must contain $\mathrm{O}_{2}$ and $\mathrm{CO}_{2}$, and the fuel gas is a mixture of $\mathrm{H}_{2}, \mathrm{CO}_{2}, \mathrm{CO}, \mathrm{CH}_{4}, \mathrm{H}_{2} \mathrm{O}$, and $\mathrm{N}_{2}$ from the fuel processing subsystem. The heat is removed by the cathode gas. Cells have been successfully operated at pressures as high as 10 atmospheres.

The Electric Power Research Institute (EPRI) and the U. S. Department of Energy (DOE) are funding molten carbonate fuel cell research, development, and engineering at General Electric Company (GE), United Technologies Corporation (UTC), Energy Research Corporation (ERC), and the Institute of Gas Technology (IGT) ${ }^{6,9}$ The work concentrates on electrolyte management, tolerance to sulfur and other impurities, engineering scale-up (cell design and mass production of components), and systems analysis.

Although molten carbonate fuel cell technology has made impressive advances, a number of questions concerning cell performance and life remain:

1. The sulfur and chlorine tolerance of the cell is only a few parts per million; the tolerance to other impurities has not been defined. 
2. Electrolyte losses result in decreases in electrolyte tile strength and bubble pressure, increased tile porosity, and diffusion of reactants across the tile causing decreases in cell voltage and efficiency. A partial solution to the evaporation problem is the incorporation of a reservoir with enough electrolyte to achieve the design life of 40,000 hours. The electrolyte may not be evenly distributed, however, and redistribution can cause performance loss. In addition, new tile and electrode structures and materials that inhibit carbonate evaporation are being sought. 10

3. Electrolyte creepage and corrosion result in failure of the wet-seal and leakage of reactants out of the cell. The wetseal is now protected by aluminizingll aithough it is uncertain whether this approach will be effective for 40,000 hours. 10

4. Effects of structural changes in the electrolyte support (LiA102) on cell performance have not been defined.

5. Cost-effective cell components ( $t i l e$, electrodes, and hardware) and manufacturing techniques must be identified.

A system problem arises from the production of $\mathrm{CO}_{2}$ at the anode and its consumption at the cathode. System efficiency requires transfer of the $\mathrm{CO}_{2}$ from the anode to the cathode. Current transfer technology involves catalytic combustion of anode exhaust $\left(\mathrm{CO}, \mathrm{H}_{2}, \mathrm{CH}_{4}, \mathrm{H}_{2} \mathrm{O}, \mathrm{N}_{2}\right.$, and $\mathrm{CO}_{2}$ ) to $\mathrm{H}_{2} \mathrm{O}$ and $\mathrm{CO}_{2}$, mixing this stream with air and feeding it to the cathode. For this system to be economical, the anode must be run at $90 \%$ $\mathrm{H}_{2}$ utilization, but such high utilization results in increased Nernst losses (Equation 2.8). More desirable would be a physical separation of the $\mathrm{CO}_{2}$ from the rest of the anode exhaust, which can be recycled to the anode. To date, studies on ways to exchange the $\mathrm{CO}_{2}$ are not complete.

Basic Concepts and Cell Components

A schematic of one repeating element in a stack of molten carbonate fuel cells is shown in Figure 4.2. The electrolyte tile, described below, is held in place between the two stainless-steel cell housings that form the anode and cathode cavities. The holding force maintains low-resistance contacts between the electrodes and the stainless steel current collectors and causes the housings to bite into the electrolyte tile, forming a wet-seal that prevents leakage of fuel from the anode chamber and oxidant from the cathode chamber. In a stack of several cells (series connection) 
the cell separator must be able to withstand both the high-humidity reducing environment of the anode and the oxidizing environment of the cathode.

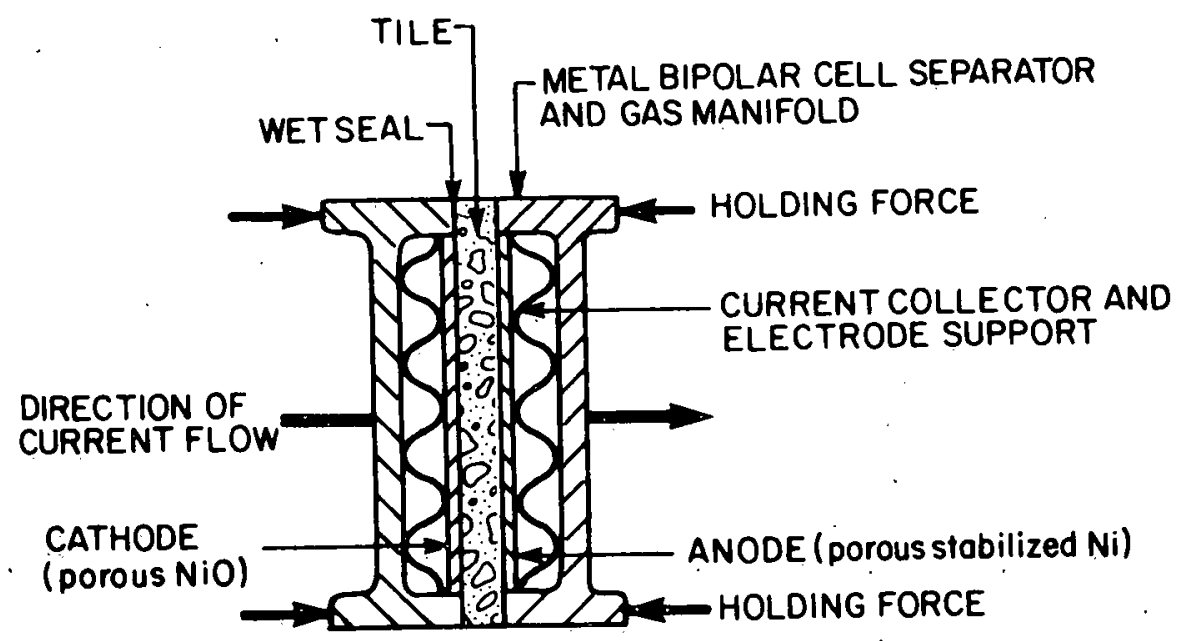

A79092012

Figure 4.2. MOLTEN CARBONATE FUEL CELL SCHEMATIC ${ }^{8}$

Carbon dioxide and oxygen diffuse from the bulk gas through the pores of the cathode to a reaction site at the electrode/electrolyte interface where they react according to -

$$
\mathrm{CO}_{2}+1 / 2 \mathrm{O}_{2}+2 \mathrm{e}^{-\rightleftarrows} \mathrm{CO}_{3}=
$$

The cathode is $70 \%$ to $80 \%$ porous $\mathrm{NiO}$ with a mean pore size of about $10 \mu \mathrm{m}, 8$ formed by the oxidation of sintered nickel at operating temperatures.

The $\mathrm{CO}_{3}=$ is conducted through the liquid electrolyte, a mixture of alkali carbonates (commonly binary: 62 or 50 mole percent $\mathrm{Li}_{2} \mathrm{CO}_{3}$, balance $\mathrm{K}_{2} \mathrm{CO}_{3}$ ) molten at cell operating temperatures. The electrolyte is held in place by inert $\mathrm{LiAlO}_{2}$ particles to form the electrolyte tile (40 weight percent inert, 60 weight percent electrolyte). Because iR loss is a function of tile thickness, tiles art kept as thin as possible, 1.0 to $2.5 \mathrm{~mm}$ in current cells.

At the anode/electrolyte interface, carbonate ions react according to Reaction 4.2, and the external circuit is completed: 


$$
\mathrm{H}_{2}+\mathrm{CO}_{3}=+\mathrm{H}_{2} \mathrm{O}+\mathrm{CO}_{2}+2 \mathrm{e}^{-}
$$

The anode is sintered nickel about $60 \%$ to $70 \%$ porous with a $5 \mu \mathrm{m}$ mean pore size. ${ }^{8}$ The product $\mathrm{H}_{2} \mathrm{O}$ and $\mathrm{CO}_{2}$ diffuse out of the cell through the porous anode into the gas stream. The overall reaction in the molten carbonate fuel cell is -

$$
\mathrm{H}_{2}+1 / 2 \mathrm{O}_{2}+\mathrm{H}_{2} \mathrm{O}(\mathrm{g})+\text { heat }
$$

\section{Molten Carbonate Fuel Cell Performance}

General Considerations. The performance of a typical 1977 molten carbonate fuel cell operating at 0.785 volt was shown in Figure 4.1. For a cell operating on reformed natural gas fuel at $75 \%$ total $\mathrm{H}_{2}$ utilization and on an oxidant mixture of $70 \%$ air and $30 \% \mathrm{CO}_{2}$ at $50 \% \mathrm{CO}_{2}$ utilization, at $200 \mathrm{~mA} / \mathrm{cm}^{2}$, losses are approximately $68 \mathrm{mV}$ ohmic and $260 \mathrm{mV}$ polarization losses. 8 of course, these losses depend on fuel and oxidant concentrations and utilizations and other fuel cell operating variables. It is difficult to separate the effects when relating cell performance to a single operating parameter.

For example, at the operatini temperature $650^{\circ} \mathrm{C}$, changes in temperature and pressure cause changes in the reactant gas composition through the following chemical equilibria:

$$
\begin{aligned}
& \mathrm{CO}+\mathrm{H}_{2} \mathrm{O} \rightleftarrows \mathrm{CO}_{2}+\mathrm{H}_{2} \\
& \mathrm{CH}_{4}+\mathrm{H}_{2} \mathrm{O} \rightleftarrows \mathrm{CO}+3 \mathrm{H}_{2} \\
& 2 \mathrm{CO} \rightleftarrows \mathrm{CO}_{2}+\mathrm{C}(\mathrm{s})
\end{aligned}
$$

Although the following analyses take this problem into account, results should still be considered directional.

The remainder of this chapter considers the effect of operating parameters on cell performance through data, derived equations, and an illustration of the use of this information to predict cell behavior at different conditions. For the purposes of this discussion, molten carbonate fuel cell performance at atmospheric pressure and $650^{\circ} \mathrm{C}$, using a cell operating on simulated reformed methane fuel* at low utilization and on an oxjdant consisting of 67 mole percent

The composition is $60 \mathrm{~mol} \% \mathrm{H}_{2}^{-}, 10 \mathrm{~mol} \% \mathrm{CO}, 7.4 \mathrm{~mol} \% \mathrm{CO}_{2}$, and $22.6 \mathrm{~mol} \%$ $\mathrm{H}_{2} \mathrm{O}$. Pure hydrogen data are unavailable because the absence of $\mathrm{CO}_{2}$ in the fuel gas causes compositional changes in the electrolyte. 12 
$\mathrm{CO}_{2}$ and 33 mole percent $\mathrm{O}_{2}{ }^{*}$ at low utilization, will be considered as baseline. The electrolyte tile.composition is 40 weight percent inert $\mathrm{LiAlO}_{2}$ particles to provide structural integrity and 60 weight percent binery eutectic mixture of $\mathrm{Li}_{2} \mathrm{CO}_{3}$ and $\mathrm{K}_{2} \mathrm{CO}_{3}$ as the electrolyte. ${ }^{* *}$ The baseline performance is shown in Figure 4.3 .12

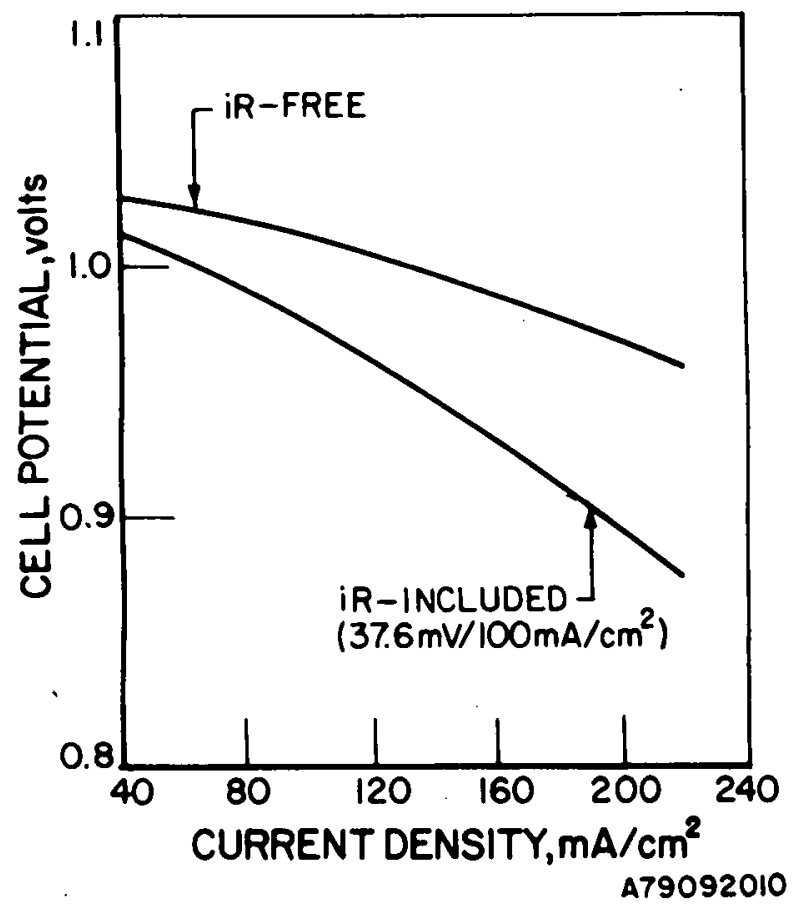

Figure 4.3. BASELINE MOLTEN CARBONATE FUEL CELL PERFORMANCE AT $1 \mathrm{atm,} 650^{\circ} \mathrm{C}$, $67 \mathrm{~mol} \% \mathrm{CO}_{2} / 33 \mathrm{~mol} \% \mathrm{O}_{2}$ OXIDANT AT $15 \%$ UTILIZATION, $60 \mathrm{~mol} \% \mathrm{H}_{2} /$

$10 \mathrm{~mol} \% \mathrm{CO} / 7.4 \mathrm{~mol} \% \mathrm{CO}_{2} / 22.6 \mathrm{~mol} \% \mathrm{H}_{2} \mathrm{O}$ FUEL AT $25 \%$ UTILIZATION

Design Considerations. The factors involved in choosing the operating design point are the same as for the phosphoric acid fuel cell: size, cost, heat removal, and voltage and power constraints. Gas composition and utilization, temperature, pressure, and impurity concentrations define the performance curve. For the baseline cell operating at $100 \mathrm{~mA} / \mathrm{cm}^{2}(0.977$ volt $)$, $91.5 \mathrm{~W} / \mathrm{ft}^{2}$ are generated, and 1 kilowatt requires $11 \mathrm{ft}^{2}$. At $200 \mathrm{~mA} / \mathrm{cm}^{2}$

* This composition results in equal utilization of $\mathrm{CO}_{2}$ and $\mathrm{O}_{2}$ by Equation 4.1 and has no diluents.

$* *$

The eutectic composition is approximately 47 weight $\% \mathrm{Li}_{2} \mathrm{CO}_{3}$ and 53 weight $\% \mathrm{~K}_{2} \mathrm{CO}_{3}$. 
$(0.895 \mathrm{volt}), 168 \mathrm{~W} / \mathrm{ft}^{2}$ are produced, and $6 \mathrm{ft}^{2}$ are required to produce 1 kilowatt. Molten carbonate fuel cells operating on leaner fuel and oxidant gases are expected to generate about 0.75 volt $/ \mathrm{cell}$ at $160 \mathrm{~mA} / \mathrm{cm}^{2}$.

Effect of Temperature. As the molten carbonate fuel cell operating temperature is increased through its range of 600 to $700^{\circ} \mathrm{C}$, hydrogen is consumed for a gas in water gas shift equilibrium because the equilibrium constant $\mathrm{K}_{\mathrm{p}}$ is proportional to temperature:

$$
\begin{array}{r}
\mathrm{H}_{2}+\mathrm{CO}_{2} \\
\quad \mathrm{~K}_{\mathrm{p}}=\frac{{ }_{\mathrm{CO}}+\mathrm{H}_{2} \mathrm{O} \mathrm{P}_{2} \mathrm{O}}{\mathrm{P}_{\mathrm{H}_{2}} \mathrm{P}_{\mathrm{CO}_{2}}}
\end{array}
$$

Thus, the middle term of the Nernst equation decreases. Because $\mathrm{E}_{\mathrm{o}}$ also decreases with increasing temperature, the open-circuit potential decreases as temperature increases:

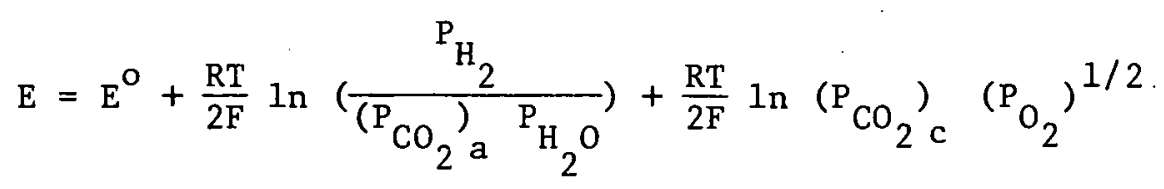

However, ohmic, activation, and concentration polarizations all decrease, more than offsetting, the decrease in the open-circuit potential. Figure 4.4 is representative of the resulting net increase in cell performance and also shows that the anode is only slightly affected by changes in cell temperature. Data for the fuel compositions listed in Table 4.1 are similar.12 Because all these cases exhibit similar behavior, a composite curve was constructed and the voltage gains determined (Figure 4.5). The data are represented by -

$$
\begin{aligned}
& \Delta \mathrm{V}_{\mathrm{T}}(\mathrm{mV})=1.5\left(\mathrm{~T}_{2}-\mathrm{T}_{1}\right){ }^{\circ} \mathrm{C} \text { for } 600^{\circ} \text { to } 650^{\circ} \mathrm{C} \\
& \Delta \mathrm{V}_{\mathrm{T}}(\mathrm{mV})=0.26\left(\mathrm{~T}_{2}-\mathrm{T}_{1}\right){ }^{\circ} \mathrm{C} \text { for } 650^{\circ} \text { to } 700^{\circ} \mathrm{C}
\end{aligned}
$$

In conclusion, the diminishing gains in cell performance above $650^{\circ} \mathrm{C}$, coupled with increased electrolyte loss resulting from evaporation ${ }^{4}$ and increased component corrosion, 13 point to an optimum operating temperature of $650^{\circ} \mathrm{C}$ for molten carbonate fuel cells with an electrolyte tile composed of $40 \% \mathrm{LiAlO}_{2}, 28 \% \mathrm{~K}_{2} \mathrm{CO}_{3}$, and $32 \% \mathrm{LiCO}_{3}$ by weight. 


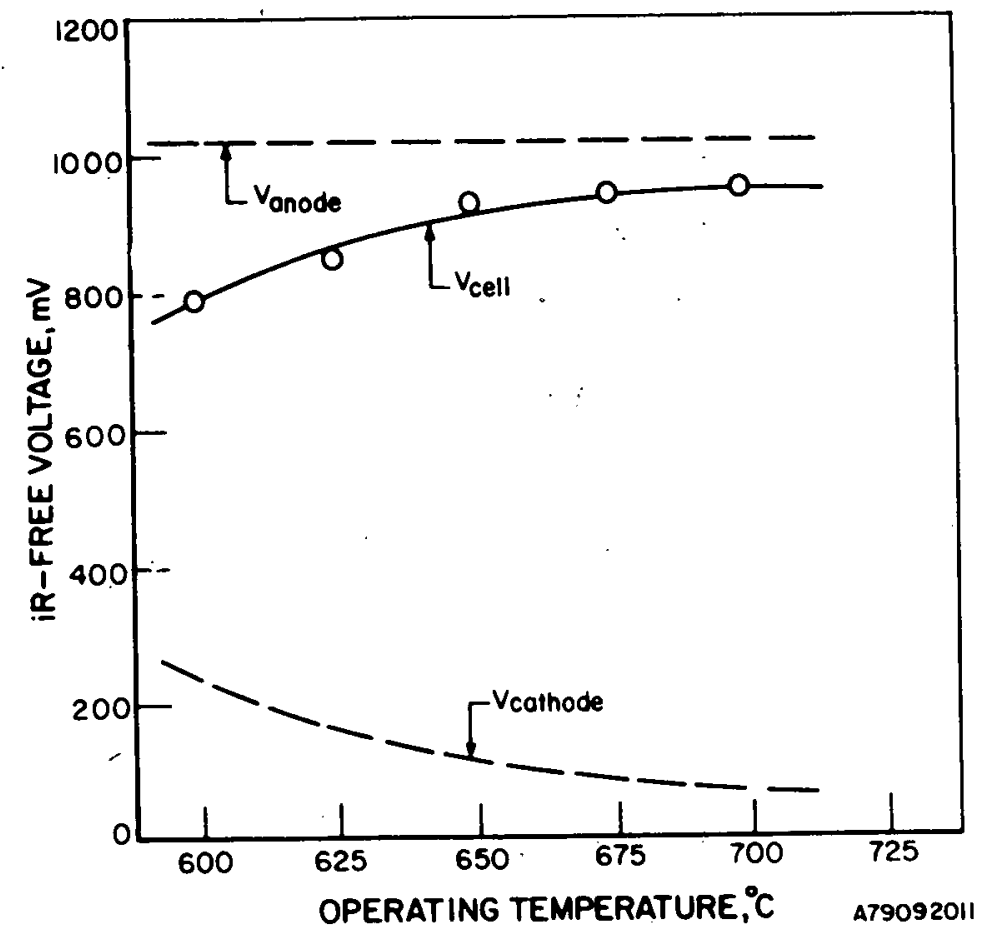

FIgure 4.4. EFFECT OF TEMPERATURE ON CELL, ANODE, AND CATHODE PERFORMANCE AT $1 \mathrm{~atm}, 650^{\circ} \mathrm{C}, 200 \mathrm{~mA} / \mathrm{cm}^{2}$, AND LOW UTILIZATIONS

Table 4.1: SIMULATED FUEL PROCESSOR PRODUCT GAS COMPOSITIONS ${ }^{12}$

Fue1 Treatment

Methane Steam Reforming

Naphtha Steam Reforming

Partial Oxidation of Heavy Oils*

Air-Blown Low-Btu Coal Gasification*

Advanced Coal Gasification/ Steam Reforming
Product Gas Composition, $\operatorname{mol} \%$ at $650^{\circ} \mathrm{C}$

\begin{tabular}{|c|c|c|c|c|c|}
\hline$\overline{\mathrm{CO}}$ & $\mathrm{CO}_{2}$ & $\dot{\mathrm{H}}_{2}$ & $\mathrm{H}_{2} \mathrm{O}$ & $\mathrm{CH}_{4}$ & $N_{2}$ \\
\hline 10.0 & 7.4 & 60.0 & 22.6 & -- & - \\
\hline 10.7 & 10.4 & 52.7 & 26.2 & 0.2 & -- \\
\hline 25.1 & 14.5 & 45.1 & 13.3 & 0.2 & 0.2 \\
\hline 14.0 & 11.4 & 18.6 & 7.8 & 2.4 & 45.8 \\
\hline
\end{tabular}

$29.1 \quad 14.0 \quad 44.3$

10.9

1.6

0.1

* Additional water added to prevent carbon formation.

60 


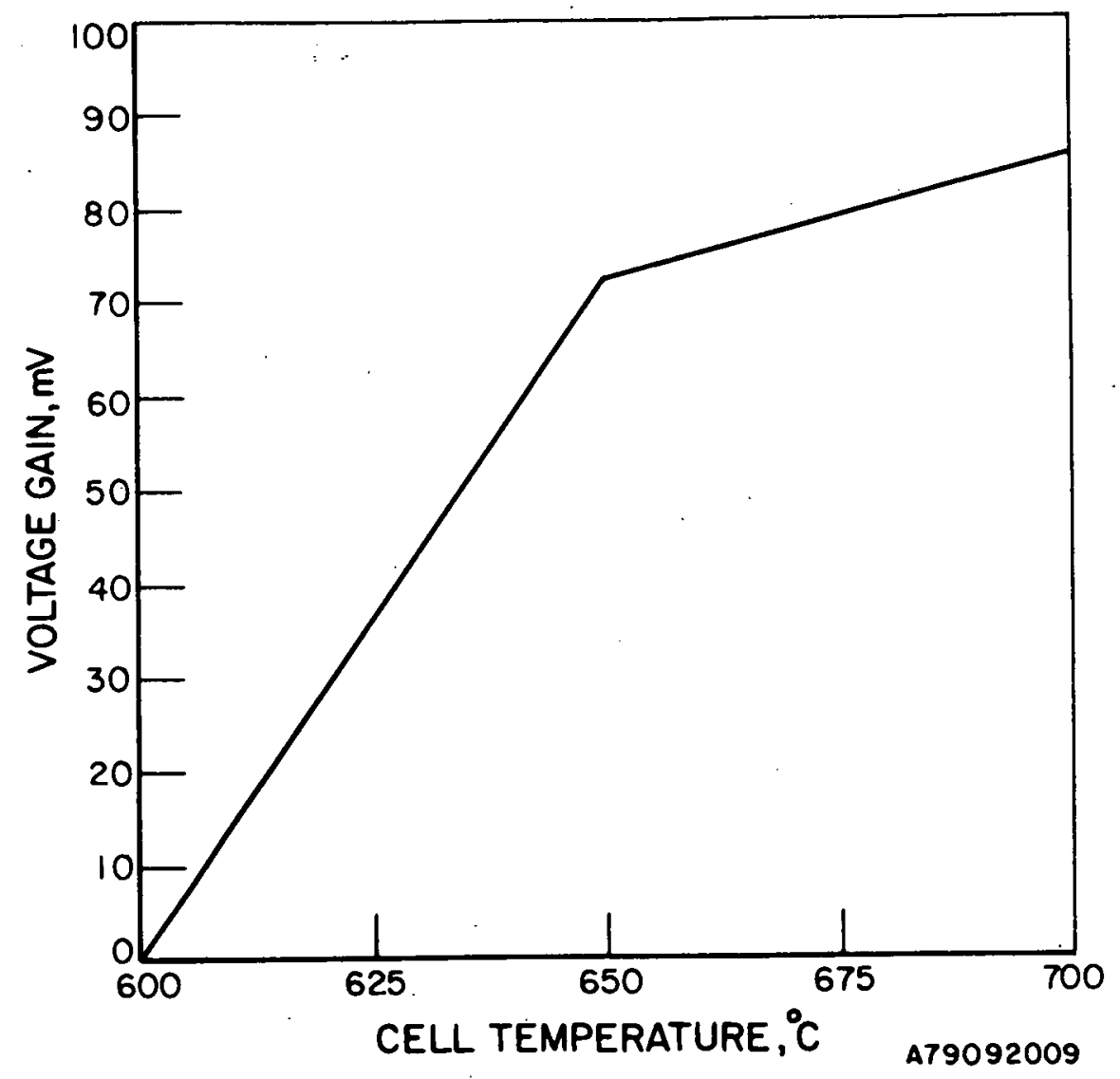

Figure 4.5. EFFECT OF TEMPERATURE ON MOLTEN CARBONATE FUEL CELL PERFORMANCE AT $1 \mathrm{~atm}, 200 \mathrm{~mA} / \mathrm{cm}^{2}, 70 \mathrm{~mol} \%$ AIR/30 $\mathrm{mol} \% \mathrm{CO}_{2}$ OXIDANT AT $50 \%$ UTILIZATION, 75\% FUEL.UTILIZATION

Effect of Pressure. Cell performance increases with pressure because of increased reactant partial pressures (Equation 4.9), increased reactant solubilities, and increased mass transport rates. Analysis of cell behavior must consider the chemical equilibria -

$$
\begin{aligned}
& 2 \mathrm{CO} \underset{\leftarrow}{\rightarrow}(\mathrm{s})+\mathrm{CO}_{2} \\
& \mathrm{CO}+3 \mathrm{H}_{2} \rightleftarrows \mathrm{CH}_{4}+\mathrm{H}_{2} \mathrm{O} \\
& \mathrm{CO}_{2}+\mathrm{H}_{2} \stackrel{\rightarrow}{ } \mathrm{CO}+\mathrm{H}_{2} \mathrm{O}
\end{aligned}
$$

Higher pressures tend to favor carbon formation and consumption of $\mathrm{CO}$ and $\mathrm{H}$. fuel. 15,16. The addition of water controls carbon formation, because it reduces the amount of $\mathrm{CO}$ (by Equation 4.14) and methanation (by forcing Equation 4.13 toward $\left.\mathrm{H}_{2}\right) .12$

Figure 4.6 shows the effect of pressure on cell performance. As shown 61 
in Table 4.2, the fuel gas was humidifed to inhibit carbon and methane formation. The equilibrium compositions can be obtained by adjusting the compositions in Table 4.1 according to Equations 4.13 and 4.14 and the dew point.

Table 4.2. FUEL GAS DEW POINT FOR DATA IN FIGURE 4.6 Fue1

Simulated Air-Blown Low-Btu Coal Gas

Pressure, atm

Dew Point, ${ }^{\circ} \mathrm{F}$

1

5

10

1

5
164

260

300

145

190

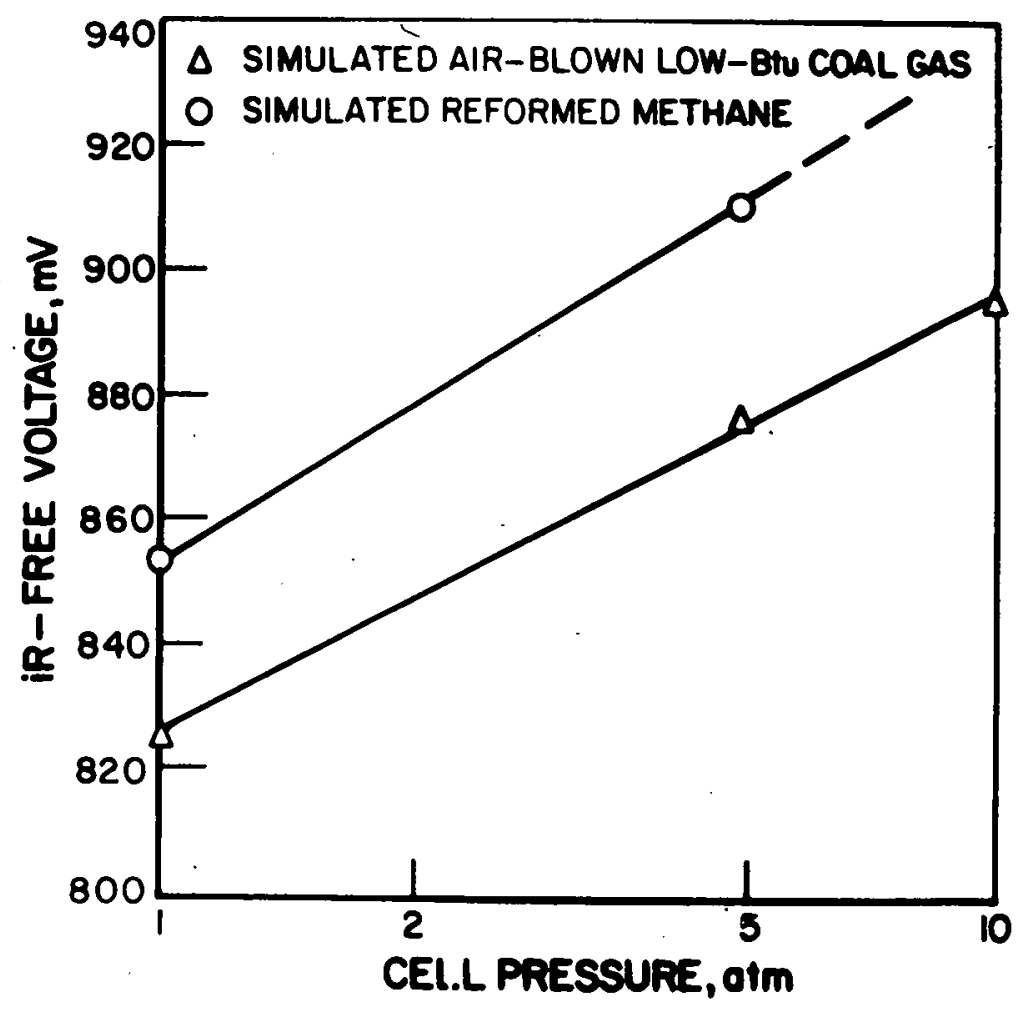

A79092014

Figure 4.6. EFFECT OF PRESSURE ON MOLTEN CARBONATE FUEL CELL PERFORMANCE AT $650^{\circ} \mathrm{C}, 160 \mathrm{~mA} / \mathrm{cm}^{2}, 70 \mathrm{~mol} \%$ AIR $/ 30 \% \mathrm{~mol} \mathrm{CO}_{2}$ OXIDANT AT 50\% UTILIZATION, $75 \%$ FUEL UTILIZATION 14

For the product gas of an air-blown low-Btu coal gasifier, the relationship between changes in cell performance and operating pressure in atmospheres is - 


$$
\Delta V_{p}(m V)=70 \log \frac{P_{2}}{P_{1}}
$$

and for reformed methane, it is -

$$
\Delta V_{p}(m V)=83 \log \frac{P_{2}}{P_{1}}
$$

Because these two cases represent a wide range of gas composition, other fuels should obey the average relationship:

$$
\Delta V_{p}(m V)=76.5 \log \frac{P_{2}}{P_{1}}
$$

Optimization of cell operating pressure must also consider the strict pressure control required to prevent wet-seal and tile failure, compatibility with the fuel processor pressure, and the possiblè corrosion of cell components at the resulting higher voltages. Molten carbonate fuel cells are expected to operate between 1 and 10 atmospheres.

Effect of Reactant Concentration and Utilization. Although considerable data have been published, the effect of reactant partial pressure on molten carbonate fuel cell performance is difficult to analyze because of the participation of $\mathrm{CO}$ at the anode via the water-gas shift reaction (Equation 4.14) and because of consumption of $\mathrm{CO}_{2}$ and $\mathrm{O}_{2}$ at the cathode (Equation 4.1). Figure 4.7 is representative of data published on reactant utilization. ${ }^{7,12,17}$ The data indicate that increasing oxidant utilization causes less cell potential loss than increases in fuel utilization. Once again a compromise is required, because operating at low fuel utilization increases cell performance but decreases the current efficiency. (See Chapter 5.) Current molten carbonate fuel cells commonly run at 75 to $85 \%$ fuel utilization and $50 \%$ oxidant utilization.

oxidant. According to the Nernst equation, cell performance should be related to oxidant $\left(\mathrm{CO}_{2}, \mathrm{O}_{2}\right)$ partial pressure by $\ln \left[\left(\mathrm{P}_{\mathrm{CO}_{2}}\right)\left(\mathrm{P}_{\mathrm{O}_{2}}\right)^{1 / 2}\right]$. The range of conditions 1 isted in Table 4.3 have been used to define this functionality at 1 atmosphere total pressure, as shown in Figure 4.8. 


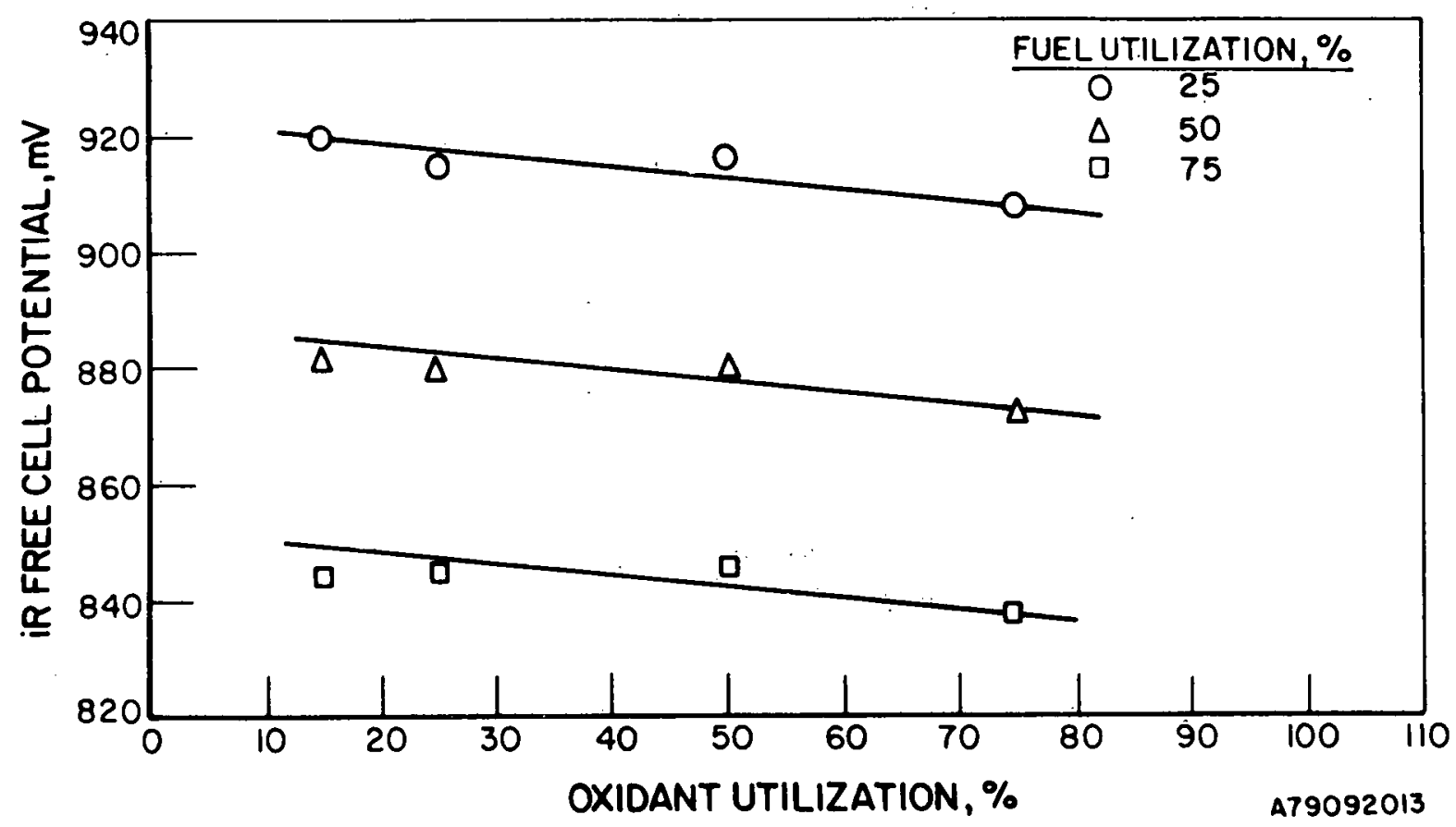

Figure 4.7. EFFECT OF REACTANT UTILIZATION ON MOLTEN CARBONATE FUEL CELL PERFORMANCE AT $1 \mathrm{~atm}, 650^{\circ} \mathrm{C}, 160 \mathrm{~mA} / \mathrm{cm}^{2}, 70 \mathrm{~mol} \% \mathrm{AIR} / 30 \mathrm{~mol} \% \mathrm{CO}_{2}$ OXIDANT, SIMULATED REFORMED METHANE FUEL ${ }^{1.2}$

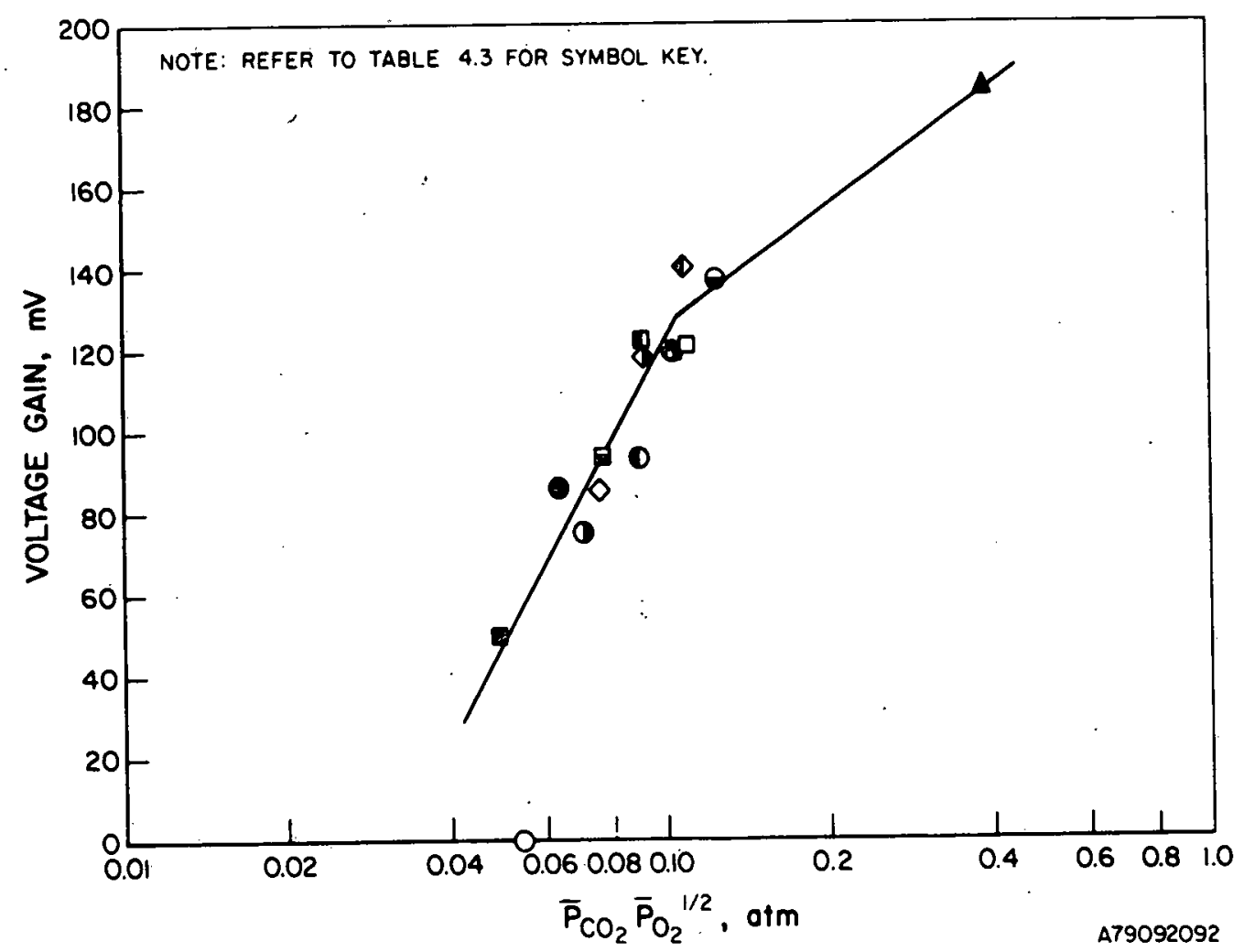

Figure 4.8. EFFECT OF OXIDANT PARTIAL PRESSURE ON MOLTEN CARBONATE FUEL CELL PERFORMANCE AT I atm TOTAL PRESSURE, $650^{\circ} \mathrm{C}, 160 \mathrm{~mA} / \mathrm{cm}^{2}$ 
Table 4.3. SUMMARY OF DATA IN FIGURE 4.8

\begin{tabular}{|c|c|c|c|c|c|c|}
\hline & \multicolumn{5}{|c|}{ OXIDANT } & \multirow{3}{*}{ FUEL } \\
\hline & \multicolumn{2}{|c|}{ COMPOSITION } & \multicolumn{2}{|c|}{ UTILIZATION, \% } & \multirow{2}{*}{$\frac{\mathrm{P}_{\mathrm{CO}_{2}}}{\mathrm{P}_{\mathrm{O}_{2}}}$} & \\
\hline & $\mathrm{CO}_{2}$ & $\mathrm{O}_{2}$ & $\mathrm{CO}_{2}$ & $\mathrm{O}_{2}$ & & \\
\hline$\Delta$ & 0.67 & 0.33 & $25-75$ & AVG & 2 & SIMULATED REFORMEO \\
\hline 0 & 0.30 & 0.15 & 15 & 15 & 2 & $\begin{array}{l}\text { ME.THANE AT 75\% } \\
\text { UTIIIZATION }\end{array}$ \\
\hline $\mathbf{0}$ & 0.30 & 0.15 & 25 & 25 & 2 & \\
\hline $\mathbf{0}$ & 0.30 & 0.15 & 50 & 50 & 2 & \\
\hline 日 & 0.30 & 0.15 & 75 & 75 & 2 & \\
\hline 0 & 0.30 & 0.05 & 25 & 69 & 6 & \\
\hline 0 & 0.30 & 0.08 & 25 & 48 & 3.75 & \\
\hline D & 0.30 & 0.12 & 25 & 33 & 2.5 & \\
\hline$\theta$ & 0.30 & 0.15 & 25 & 25 & 2 & $\therefore$ \\
\hline$\theta$ & 0.30 & 0.20 & 25 & 19 & 1.5 & \\
\hline$\diamond$ & 0.30 & 0.12 & 50 & 65 & 2.5 & \\
\hline$\diamond$ & 0.30 & 0.15 & 50 & 50 & 2 & \\
\hline$\diamond$ & 0.30 & 0.20 & 50 & 38 & 1.5 & \\
\hline 0 & 0.125 & 0.17 & 25 & 68 & 0.74 & $\begin{array}{l}\text { SIMULATED REFORMED } \\
\text { NAPHTHA AT } 75 \% \\
\text { UTILIZATION }\end{array}$ \\
\hline D & 0.21 & 0.14 & 50 & 68 & 1.5 & $\begin{array}{l}\text { SIMULATED AIR-BLOWN } \\
\text { COAL GAS AT } 75 \% \\
\text { UTILIZATION }\end{array}$ \\
\hline
\end{tabular}

A79092093

At low oxidant partial pressures, the gains are caused by diminishing mass transfer effects in addition to the Nernst gains. As the partial pressures increase further, mass transfer losses become negligible and the gains become governed by Nernst effects, that is; the slope approximates $2.3 \mathrm{RT} / 2 \mathrm{~F}$. The mathematical representation of the data in terms of atmospheres is -

$$
\Delta \mathrm{V}_{\mathrm{ox}}(\mathrm{mV})=250 \log \frac{\left(\overline{\mathrm{P}}_{\mathrm{CO}_{2}} \overline{\mathrm{P}}_{\left.\mathrm{O}_{2}{ }^{1 / 2}\right)_{2}}\right.}{\left(\overline{\mathrm{P}}_{\mathrm{CO}_{2}} \overline{\mathrm{P}}_{\left.\mathrm{O}_{2}{ }^{1 / 2}\right)_{1}}\right.}
$$

$$
\text { for } 0.04 \leq \overline{\mathrm{P}}_{\mathrm{CO}_{2}} \overline{\mathrm{P}}_{\mathrm{O}_{2}} 1 / 2 \leq 0.11
$$




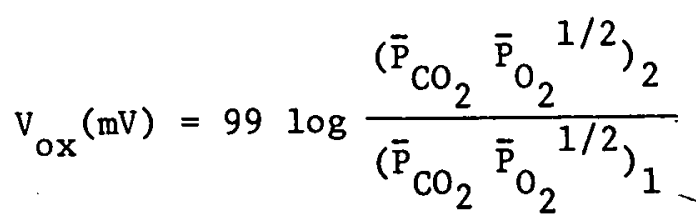

$$
\begin{aligned}
& \text { for } 0.11 \leq \overline{\mathrm{P}}_{\mathrm{CO}_{2}} \cdot \overline{\mathrm{P}}_{\mathrm{O}_{2}}{ }^{1 / 2} \leq 0.38
\end{aligned}
$$

Equations 4.18 and 4.19 should be used cautiously when the oxidant composition deviates significantly from the stoichiometric ratio of $\mathrm{P}_{\mathrm{CO}_{2}} / \mathrm{P}_{\mathrm{O}_{2}}=2$. In such cases, a low partial pressure of either $\mathrm{CO}_{2}$ or $\mathrm{O}_{2}$ could result in severe concentration polarization, even though $\overline{\mathrm{P}}_{\mathrm{CO}_{2}} \overline{\mathrm{P}}_{\mathrm{O}_{2}}{ }^{1 / 2}$ is within the range of Figure 4.8.

Fuel. Based on the data in Figure 4.7 and Table 4.4 and the assumption that the anode gas is always in shift equilibrium, the effect of the average. hydrogen partial pressure in atmospheres is shown in Figure 4.9 and represented by -

$$
\Delta \mathrm{V}_{\mathrm{F}}(\mathrm{mV})=173 \log \frac{\left[\overline{\mathrm{P}}_{\mathrm{H}_{2}} / \overline{\mathrm{P}}_{\mathrm{CO}_{2}} \overline{\mathrm{P}}_{\mathrm{H}_{2} \mathrm{O}}{ }_{2}\right.}{\left[\overline{\mathrm{P}}_{\mathrm{H}_{2}} / \overline{\mathrm{P}}_{\mathrm{CO}_{2}} \overline{\mathrm{P}}_{\mathrm{H}_{2} \mathrm{O}}\right]_{1}}
$$

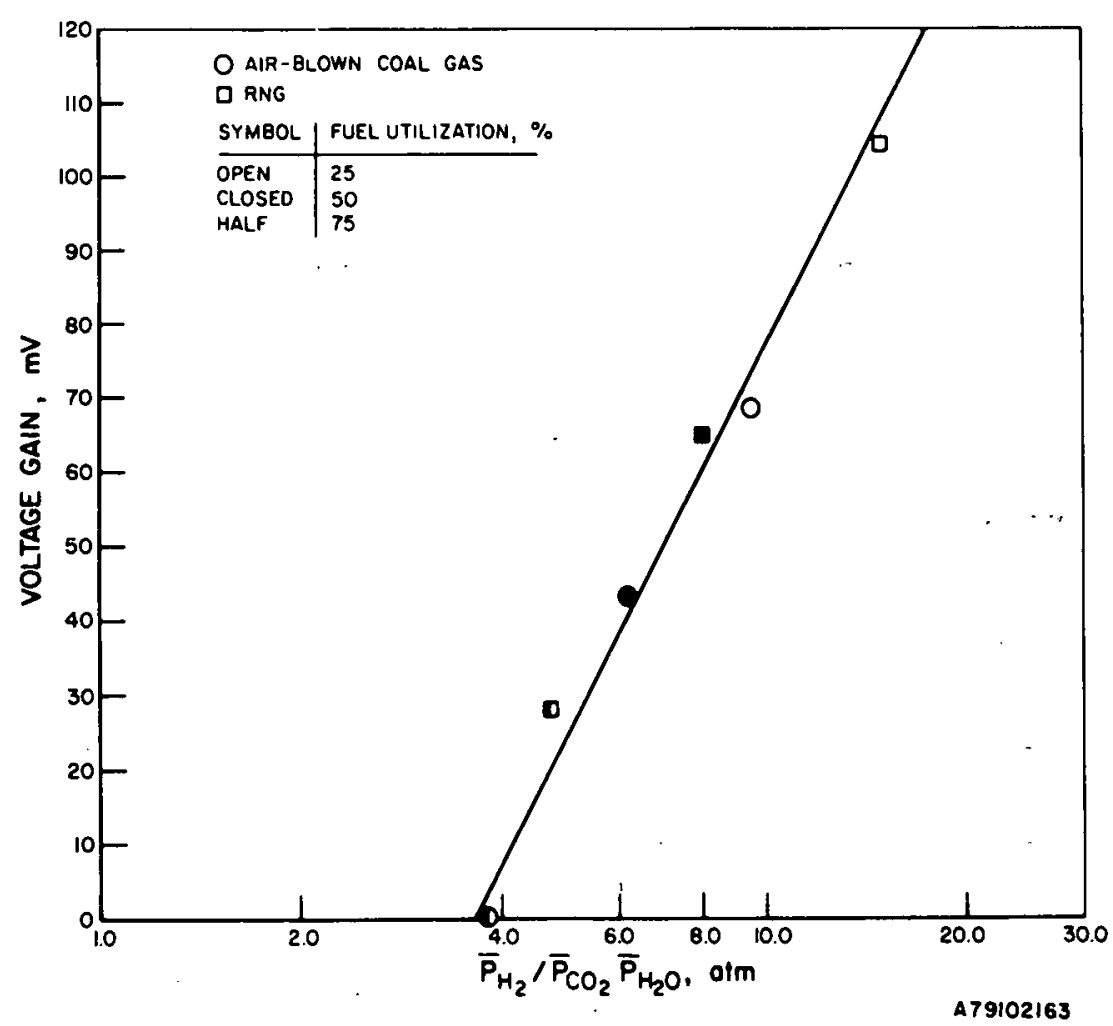

Figure 4.9. EFFECT OF FUEL PARTIAL PRESSURE ON MOLTEN CARBONATE FUEL CELL PERFORMANCE AT 1 atm TOTAL PRESSURE, $650^{\circ} \mathrm{C}, 160 \mathrm{ma} / \mathrm{cm}^{2}$ 
Table 4.4. APPLICABLE RANGE OF DATA FOR EQUATION 4.20

\begin{tabular}{|c|c|c|c|c|c|}
\hline \multicolumn{2}{|c|}{ Fuel } & \multicolumn{2}{|c|}{ Oxidant } & \multirow[b]{2}{*}{$\mathrm{P}_{\mathrm{CO}_{2}} / \mathrm{P}_{\mathrm{O}_{2}}$} & \multirow{2}{*}{$\begin{array}{l}\text { Current } \\
\text { Density, } \\
\mathrm{mA} / \mathrm{cm}^{2}\end{array}$} \\
\hline Composition & $\begin{array}{c}\text { Utilization, } \\
\% \\
\end{array}$ & $\begin{array}{c}\text { Composition, } \\
\text { mo1 } \% \\
\end{array}$ & $\begin{array}{c}\text { Utilization, } \\
\% \\
\end{array}$ & & \\
\hline Table 4.1 & 25 to 75 & $\begin{array}{lll}70 & \mathrm{Air} / 30 & \mathrm{CO}_{2} \\
33 & \mathrm{O}_{2} / 67 & \mathrm{CO}_{2}\end{array}$ & 15 to 75 & 2 & 80 to 200 \\
\hline
\end{tabular}

Effects of Impurities. Many discussions have centered on integrating the molten carbonate fuel cell with advanced fuel processors because of its tolerance to $\mathrm{CO}$ at the anode and $\mathrm{CO}_{2}$ at the cathode. Other compounds likely to be present in the effluent of advanced fuel processors include $\mathrm{NH}_{3}$, $\mathrm{NO}_{\mathrm{X}}$, $\mathrm{SO}_{\mathbf{X}}, \mathrm{H}_{2} \mathrm{~S}$ and $\mathrm{COS}$. As with the acid system, possible synergistic effects will not be considered.

Carbon. Solid carbon can form in the cell or in system plumbing if thermodynamically favored by Equation 4.12. The addition of water prevents carbon deposition by reducing $C O$ concentrations through the water-gas shift reaction.

Carbon dioxide present in the anode feed and produced at the anode acts only as a diluent, reducing the hydrogen partial pressure. In fact, a small amount of $\mathrm{CO}_{2}$ is required to maintain the $\mathrm{LiCO}_{3} / \mathrm{K}_{2} \mathrm{CO}_{3}$ electrolyte composition. 12 of course, $\mathrm{CO}_{2}$ is required at the cathode.

Methane at the anode can be reformed to hydrogen by adding sufficient water to the fuel gas. ${ }^{14}$ If the methane is not reformed, fuel cell efficiency will decrease; energy in the methane must be recovered elsewhere in the system to maintain the total system efficiency. .

Although carbon monoxide dilutes the hydrogen, it is also consumed indirectly through the water-gas shift reaction.

Sulfur. Sulfur species affect cell operation in many ways: electrodes may be covered by adsorbed sulfur species at low sulfur levels or sulfided when $\log \frac{\mathrm{P}_{\mathrm{H}_{2}}}{\mathrm{P}_{\mathrm{H}_{2} \mathrm{~S}}} \leq 2.74 ;^{18}$ carbonate may react with the sulfur species, affecting its suitability as an electrolyte; and the anode hardware will corrode more severly in the presence of sulfur. Also, $\mathrm{CO}_{2}$ formed at the anode must be transferred to the cathode for efficient operation of the system. If it 
is transferred by burning anode exhaust containing $\mathrm{H}_{2} \mathrm{~S}$, then some $\mathrm{SO}_{\mathrm{x}}$ will be present at the cathode, primarily in the form of $\mathrm{SO}_{2}$.

Cells with nickel anodes exhibit an immediate performance reduction and

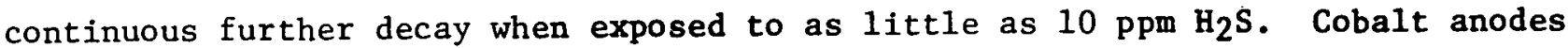
also suffer an initial performance loss but are more resistant to further decay. The kinetics of the anode reaction are unaffected by sulfur levels up to $50 \mathrm{ppm}$ so the loss may be caused by changes in the electrolyte or structural changes in the electrode. 19

Sulfur dioxide has little effect on the cathode. Instead; the sulfur dioxide absorbs into the electrolyte, reacts with it, and diffuses through the electrolyte to the anode, where it emerges as $\mathrm{H}_{2} \mathrm{~S}$ (and trace $\mathrm{COS}$ and $\mathrm{SO}_{2}$ ), possibly by the following sequence: 19

$$
\begin{array}{ll}
\mathrm{M}_{2} \mathrm{CO}_{3}+\mathrm{SO}_{2}+1 / 2 \mathrm{O}_{2} \rightleftarrows \mathrm{M}_{2} \mathrm{SO}_{4}+\mathrm{CO}_{2} & \text { (cathode) } \\
\mathrm{M}_{2} \mathrm{SO}_{4}+4 \mathrm{H}_{2} \stackrel{\rightarrow}{\leftarrow} \mathrm{M}_{2} \mathrm{~S}+4 \mathrm{H}_{2} \mathrm{O} & \text { (anode) } \\
\mathrm{M}_{2} \mathrm{~S}+\mathrm{CO}_{2}+\mathrm{H}_{2} \mathrm{O} \stackrel{\mathrm{M}}{\leftarrow} \mathrm{CO}_{3}+\mathrm{H}_{2} \mathrm{~S} & \text { (anode) }
\end{array}
$$

The overall anode reaction $18-$

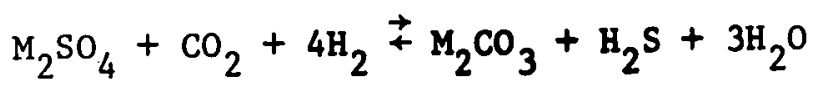

Nitrogen. Molecular nitrogen at the anode or cathode acts as a diluent. The presence of $\mathrm{NH}_{3}$ and $\mathrm{NO}_{\mathbf{x}} 18$ also expected at both anode and cathode, but no data on the effect of these impuritles on cell performance are avallable, although the $\mathrm{K}_{2} \mathrm{CO}_{3} / \mathrm{LI}_{2} \mathrm{CO}_{3} / \mathrm{Na}_{2} \mathrm{CO}_{3}$ eutectic is known to absorb No. 20

Chlorine. Recent short-term data ${ }^{21,22}$ indicate that anode performance is only slightly affected after 400 hours on a fuel gas containing $100 \mathrm{ppm}$ $\mathrm{HCl}$, but cathode performance is catastrophically affected by $100 \mathrm{ppm}$ HCl in the oxidant gas. Stable cathode performance with $10 \mathrm{ppm}$ HCl has been demonstrated for 120 hours. Although long-term trends have not been established, it appears that the decay results from both hardware corrosion and chlorination of the electrolyte.

Summary, Other Compounds. Discussions on the effects of carbon, sulfur, and nitrogen compounds on molten carbonate fuel cell performance did not consider synergistic effects. Table 4.5 summarizes estimates of maximum allowable impurity levels. 
Table 4.5. ESTIMATED MAXIMUM ALLOWABLE IMPURITY LEVELS - MOLTEN CARBONATE FUEL CELLS

\begin{tabular}{ll}
\hline \multicolumn{1}{c}{ Impurity } & Maximum Limit \\
\cline { 2 - 2 } $\mathrm{CO}_{2}$ & diluent \\
$\mathrm{CH}_{4}$ & diluent/fuel \\
$\mathrm{CO}$ & fuel \\
$\mathrm{N}_{2}$ & diluent \\
$\mathrm{H}_{2} \mathrm{~S}, \mathrm{SO}_{2}, \mathrm{COS}$ & $<1 \mathrm{ppm}$ \\
$\mathrm{C}_{2}+$ & unknown \\
$\mathrm{HCl}$ (anode) & $100 \mathrm{ppm}^{*}$ \\
$\mathrm{HC1}$ (cathode) & 10 ppm \\
$\mathrm{NH}_{3}, \mathrm{NO}_{\mathrm{x}}$ & unknown $^{*}$ \\
$\mathrm{Metal}$ ions (Fe, Cu, etc.) & unknown $^{*}$
\end{tabular}

Effect of Internal Resistance. Resistance to ionic $\left(\mathrm{CO}_{3}{ }_{3}\right)$ conduction through the electrolyte tile and to electronic conduction through electrodes, current collectors, and interfaces results in voltage reductions of 35 to 50 $\mathrm{mV} /\left(100 \mathrm{~mA} / \mathrm{cm}^{2}\right) .12$ Thinner components being developed will reduce this voltage loss. 23 The sample calculations below will use -

$$
\Delta V_{i R}(\mathrm{mV})=-0.4 i\left(\mathrm{~mA} / \mathrm{cm}^{2}\right)
$$

\section{Sample Calculations}

The data and equations summarized in Table 4.6 will be used to estimate the performance difference between the baseline cell and a cell operating on the product gas from an air-blown coal gasifier. The oxidant gas will be obtained by burning the anode effluent with excess air. ${ }^{5}$ Table 4.7 ists the differences in operating conditions and resulting performance changes.

Temperature. Because the operating temperature is above $650^{\circ} \mathrm{C}$, use Equation 4.11:

$$
\begin{aligned}
& \Delta \mathrm{V}_{\mathrm{T}}(\mathrm{mV})=0.26(675-650) \\
& \Delta \mathrm{V}_{\mathrm{T}}(\mathrm{mV})=+6.3
\end{aligned}
$$

Although data are not available, tolerance is expected to be low. 
Table 4.6. SUMMARY OF PARAMETRIC DESIGN EQUATIONS FOR MOLTEN CARBONATE FUEL CELL

Parameter

Temperature

Oxidant

4.18

4.10

4.11

4.17

Functionality

$$
\Delta \mathrm{V}_{\mathrm{T}}(\mathrm{mV})=1.5\left(\mathrm{~T}_{2}-\mathrm{T}_{1}\right)^{\circ} \mathrm{C}
$$$$
\Delta \mathrm{V}_{\mathrm{T}}(\mathrm{mV})=0.26\left(\mathrm{~T}_{2}-\mathrm{T}_{1}\right)^{\circ} \mathrm{C}
$$$$
\Delta V_{p}(m V)=76.5 \log \frac{P_{2}}{P_{1}}
$$

Fuel

4.20

Internal

Resistance
$\Delta \mathrm{V}_{\mathrm{ox}}(\mathrm{mV})=250 \log \frac{\left[\overline{\mathrm{P}}_{\mathrm{CO}} \overline{\mathrm{P}}_{\mathrm{O}_{2}}{ }^{1 / 2}\right]_{2}}{\left[\overline{\mathrm{P}}_{\mathrm{CO}_{2}} \overline{\mathrm{P}}_{\mathrm{O}_{2}}^{1 / 2}\right]_{1}}$

$\Delta \mathrm{V}_{\mathrm{ox}}(\mathrm{mV})=99 \log \frac{\left[\overline{\mathrm{P}}_{\mathrm{CO}_{2}} \overline{\mathrm{P}}_{\mathrm{O}_{2}}{ }^{1 / 2}\right]_{2}}{\left[\overline{\mathrm{P}}_{\mathrm{CO}_{2}} \overline{\mathrm{P}}_{\mathrm{O}_{2}}^{1 / 2}\right]_{1}}$

$\Delta V_{F}(m V)=173 \log \frac{\left[\overline{\mathrm{P}}_{\mathrm{H}_{2}} / \overline{\mathrm{P}}_{\mathrm{CO}_{2}} \overline{\mathrm{P}}_{\mathrm{H}_{2} \mathrm{O}}\right]_{2}}{\left[\overline{\mathrm{P}}_{\mathrm{H}_{2}} / \overline{\mathrm{P}}_{\mathrm{CO}_{2}} \overline{\mathrm{P}}_{\dot{\mathrm{H}}_{2} \mathrm{O}}\right]_{1}}$

4.25
Comments

$$
\begin{aligned}
& 600^{\circ}-650^{\circ} \mathrm{C} \\
& 650^{\circ}-700^{\circ} \mathrm{C}
\end{aligned}
$$

$0.04 \leq \overline{\mathrm{P}}_{\mathrm{CO}} \overline{\mathrm{P}}_{\mathrm{O}_{2}} 1 / 2 \leq 0.11$ atm $^{3 / 2}$
Table 4.3

$0.11 \leq \overline{\mathrm{P}}_{\mathrm{CO}_{2}} \overline{\mathrm{P}}_{\mathrm{O}_{2}} 1 / 2 \leq 0.38 \mathrm{~atm}^{3 / 2}$
Table 4.4

Table 4.4 
Table 4.7. COMPARISON UF BASELINE AND CANDIDATE MOLTEN CARBONATE FUEL CELL PERFORMANCE AND EFFECT OF CONTRIBUTING FACTORS

\begin{tabular}{|c|c|c|c|}
\hline Operating Variable & Baseline & Candidate & $\underline{\Delta V}(\mathrm{mV})$ \\
\hline Temperature, ${ }^{\circ} \mathrm{C}$ & 650 & 675 & +6.3 \\
\hline Pressure, atm & 1 & 10 & +76.5 \\
\hline Oxidant, $\operatorname{mol} \%$ & & & -142 \\
\hline $\mathrm{CO}_{2}$ & 67 & 20.5 & \\
\hline $\mathrm{O}_{2}$ & 33 & 14.0 & \\
\hline Utilization & 15 & 50.0 & \\
\hline Fuel, mol \% & & & -106 \\
\hline $\mathrm{H}_{2}$ & 60.0 & 18.6 & \\
\hline $\mathrm{CO}$ & 10.0 & 14.0 & \\
\hline $\mathrm{CO}_{2}$ & 7.4 & 11.4 & \\
\hline $\mathrm{H}_{2} \mathrm{O}$ & 22.6 & 7.8 & \\
\hline $\mathrm{N}_{2}+\mathrm{CH}_{4}$ & 0 & 48.2 & \\
\hline Utilization & 25.0 & 75.0 & \\
\hline $\begin{array}{l}\text { Interna1 Resistance, } \\
\mathrm{mV} /\left(\mathrm{mA} / \mathrm{cm}^{2}\right)\end{array}$ & -0.4 & -0.4 & 0 \\
\hline Total Change, $\mathrm{mV}$ & & & -165 \\
\hline
\end{tabular}

Fuel. To use Equation 4.20, calculate the average partial pressures of $\mathrm{CO}_{2}, \mathrm{H}_{2} \mathrm{O}$, and $\mathrm{H}_{2}$ at the anode. The procedure used in this example is -

1. Determine the equilibrium inlet composition.

2. Assume the moles of hydrogen consumed and increase the moles of $\mathrm{CO}_{2}$ and $\mathrm{H}_{2} \mathrm{O}$ stoichiometrically to determine the initial exit partial pressures.

3. Check the assumed exit composition for shift equilibrium:

$$
K_{p}=\frac{{ }^{P_{C O}}{ }^{\mathrm{P}_{\mathrm{H}_{2} \mathrm{O}}}}{\mathrm{P}_{\mathrm{CO}_{2}}{ }_{\mathrm{P}_{2}}}
$$

If the exit gas is not in shift equilibrium, equilibrate by -

$$
K_{p}=\frac{\left(P_{\mathrm{CO}}+X\right)\left(P_{\mathrm{H}_{2} \mathrm{O}}+\mathrm{X}\right)}{\left(\mathrm{P}_{\mathrm{CO}_{2}}-\mathrm{X}\right)\left(\mathrm{P}_{\mathrm{H}_{2}}-\mathrm{X}\right)}
$$


4. Calculate the number of moles of $\mathrm{H}_{2}$ from the equilibrated partial pressure and the total moles.

5. Check the utilization by -

$$
\mathrm{U}_{\mathrm{H}_{2}}=\frac{\left(\text { moles } \mathrm{H}_{2}\right) \text { in }-\left(\text { moles } \mathrm{H}_{2}\right) \text { out }}{\left(\text { moles } \mathrm{H}_{2}\right) \text { in }}
$$

6. If the utilization is not that desired, adjust the moles of hydrogen consumed and repeat the procedure until the desired utilization is achieved.

The results of the procedure for the baseline case of reformed methane at $25 \%$ utilization are summarized in Table 4.8 . The following calculations illustrate these results in detail. The number of moles of hydrogen at the fuel cell exit is assumed to be 0.47 . Therefore -

$$
\begin{aligned}
& \mathrm{H}_{2} \text { consumed }=0.60-0.47=0.13 \text { moles } \\
& \text { exit } \mathrm{CO}_{2}=0.074+0.13=0.204 \text { moles } \\
& \text { exit } \mathrm{H}_{2} \mathrm{O}=0.226+0.13=0.356 \text { moles } \\
& \text { total exit }=0.47+0.204+0.356+0.100=1.13 \text { moles }
\end{aligned}
$$

and the exit partial pressures are -

$$
\begin{aligned}
& \left(\mathrm{P}_{\mathrm{H}_{2}}\right)_{\text {out }}=\frac{0.470}{1.130}=0.416 \\
& \left(\mathrm{P}_{\mathrm{CO}_{2}}\right)_{\text {out }}=\frac{0.204}{1.130}=0.181 \\
& \left(\mathrm{P}_{\mathrm{CO}}\right)_{\text {out }}=\frac{0.100}{1.130}+0.088 \\
& \left(\mathrm{P}_{\left.\mathrm{F}_{20}\right)_{\text {out }}}=\frac{0.356}{1.130}=0.315\right.
\end{aligned}
$$

The equilibrium constant at $650^{\circ} \mathrm{C}$ is -

$$
K_{p}=0.509 \neq \frac{(0.088)(0.315)}{(0.416)(0.181)}=0.401
$$

The gas is equilibrated by -

$$
\begin{gathered}
0.509=\frac{(0.088+x)(0.315+x)}{(0.416-x)(0.181-x)} \\
0.491 x^{2}+0.707 x-0.0105=0 \\
x=0.0145
\end{gathered}
$$


Table 4.8. COMPOSITION PROFILE - REFORMED METHANE AT 25\% UTILIZATION

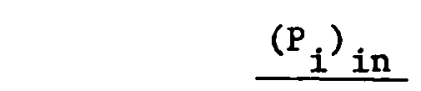

$\mathrm{H}_{2}$

$\mathrm{CO}_{2}$

Co

$\mathrm{H}_{2} \mathrm{O}$

Tota1

$\pi$

a $\tilde{\omega}$

-1
$m$
0
$I$
2
0
0
0
0

$\begin{array}{ccc}\begin{array}{c}\text { Assumed Moles } \\ \text { out }\end{array} & & \left(\mathrm{P}_{\mathrm{i}}\right)_{\text {out }} \\ 0.47 & & 0.416 \\ 0.204 & & 0.181 \\ 0.1 .00 & & 0.088 \\ 0.356 & & 0.315 \\ 1.130 & & 1.000\end{array}$

\begin{tabular}{l}
$\left(\mathrm{P}_{\mathrm{i}}\right)_{\text {out }}, \mathrm{eq}$ \\
\hline 0.402 \\
0.166 \\
0.102 \\
0.329 \\
0.999
\end{tabular}

$\left(P_{i}\right)$ ave, eq

0.500

0.120

0.101

0.278

0.999

Equilibrium Exit Moles

$$
0.454
$$

0.188

0.115

0.372

1.129

Table 4.9. COMPOSITION PROFILE - AIR-BLOWN COAL GAS AT 75\% UTILIZATTON

\begin{tabular}{|c|c|c|c|c|c|c|}
\hline & $\left(P_{i}\right)_{\text {in, eq }}$ & $\begin{array}{c}\text { Assumed Moles } \\
\text { out }\end{array}$ & $\left(P_{i}\right)_{\text {out }}$ & $\left(P_{i}\right)$ out, eq & $\left(P_{i}\right)$ ave, eq & $\begin{array}{l}\text { Equilibrium } \\
\text { Exit Moles }\end{array}$ \\
\hline $\mathrm{H}_{2}$ & 0.183 & -0.045 & -0.037 & 0.036 & 0.109 & 0.044 \\
\hline $\mathrm{CO}_{2}$ & 0.111 & 0.338 & 0.275 & 0.348 & 0.229 & .0 .427 \\
\hline $\mathrm{CO}$ & 0.144 & 0.144 & 0.117 & 0.044 & 0.094 & 0.054 \\
\hline $\mathrm{H}_{2} \mathrm{O}$ & 0.082 & 0.309 & 0.252 & 0.179 & 0.130 & $0.220^{\circ}$ \\
\hline Other & 0.482 & 0.482 & 0.393 & 0.393 & 0.438 & 0.393 \\
\hline Total & 1.002 & 1.228 & 1.000 & 1.000 & 1.000 & 1.138 \\
\hline
\end{tabular}


The equilibrium exit partial pressures are -

$$
\begin{aligned}
& \left(\mathrm{P}_{\mathrm{H}_{2}}\right)_{\text {out, eq }}=0.416-0.0145=0.402 \\
& \left(\mathrm{P}_{\mathrm{CO}_{2}}\right)_{\text {out, eq }}=0.166-0.0145=0.166 \\
& \left(\mathrm{P}_{\mathrm{CO}}\right)_{\text {out, eq }}=0.088+0.0145=0.102 \\
& \left(\mathrm{P}_{\mathrm{H}^{2}}\right)_{\text {out }} \text { eq }
\end{aligned}
$$

and

$$
\text { equilibrium exit } \mathrm{H}_{2}=(0.402)(1.13)=0.454 \text { moles. }
$$

The hydrogen utilization is -

$$
\mathrm{U}_{\mathrm{H}_{2}}=\left(\frac{0.60-0.454}{0.60}\right) 100=24.3 \%
$$

The target utilization of $25 \%$ has been achieved. The average equilibrium partial pressures are -

$$
\begin{aligned}
& \left(\mathrm{P}_{\mathrm{H}_{2}}\right)_{\text {ave, eq }}=\frac{.60+.402}{2}=0.50 \\
& \left(\mathrm{P}_{\left.\mathrm{CO}_{2}\right)}\right)_{\text {ave, eq }}=\frac{0.074+0.166}{2}=0.12 \\
& \left(\mathrm{P}_{\mathrm{CO}}\right)_{\text {ave, eq }}=\frac{0.100+0.102}{2}=0.101 \\
& \left(\mathrm{P}_{\mathrm{H}_{2} \mathrm{O}}\right)_{\text {ave, eq }}=\frac{0.226+0.329}{2}=0.278
\end{aligned}
$$

Results of the determination of the average component partial pressures for the cell operating at $675^{\circ} \mathrm{C}(\mathrm{Kp}=0.58)$ on product gas from an air-blown coal gasifier and $75 \%$ hydrogen utilization are summarized in Table 4.9. Note that the inlet gas has been equilibrated at $675^{\circ} \mathrm{C}$. The target hydrogen utilization has been achieved:

$$
\mathrm{U}_{\mathrm{H}_{2}}=\left(\frac{0.183-0.044}{0.183}\right)(100)=76 \%
$$

The voltage change caused by the inlet fuel composition and hydrogen utilization is obtained by substituting the average $\mathrm{H}_{2}, \mathrm{CO}_{2}$ and $\mathrm{H}_{2} \mathrm{O}$ partial pressures from Tables 4.8 and 4.9 into Equation 4.20: 


$$
\begin{gathered}
\Delta \mathrm{V}_{\mathrm{F}}=173 \log \left[\frac{0.109 /(0.229)(0.130)}{0.50 /(0.12)(0.278)}\right] \\
\Delta \mathrm{V}_{\mathrm{F}}=-106 \mathrm{mV}
\end{gathered}
$$

Oxidant. To use Equations 4.18 and 4.19, determine average $\mathrm{CO}_{2}$ and $\mathrm{O}_{2}$ partial pressures. For the baseline cell operating on 67 mole $\% \mathrm{CO}_{2}$ and 33 mole $\% \mathrm{O}_{2}$, partial pressures are constant because there are no inerts to cause dilution as the reactants are consumed. Therefore -

$$
\left(\overline{\mathrm{P}}_{\mathrm{CO}_{2}} \overline{\mathrm{P}}_{\mathrm{O}_{2}}^{1 / 2}\right)_{1}=(0.67)(0.33)^{1 / 2}=0.385
$$

The candidate operating conditions involve nitrogen at the cathode, so the reactants are diluted as they are consumed. Therefore, determine a

\begin{tabular}{|c|c|c|c|c|}
\hline & Moles in & Moles out & $\left(P_{i}\right)$ out, atm & $\left(P_{i}\right)$ ave, atm \\
\hline $\mathrm{CO}_{2}$ & 0.205 & 0.065 & 0.082 & 0.144 \\
\hline $\mathrm{o}_{2}$ & 0.140 & 0.070 & 0.089 & 0.115 \\
\hline $\mathrm{N}_{2}$ & 0.655 & 0.655 & 0.829 & 0.742 \\
\hline Total & 1.000 & 0.790 & 1.000 & 1.001 \\
\hline
\end{tabular}
concentration profile as summarized in Table 4.10.

Table 4.10. COMPOSITION PROFILE OF OXIDANT AT 50\% UTILIZATION

Thus,

$$
\left(\overline{\mathrm{P}}_{\mathrm{CO}_{2}} \overline{\mathrm{P}}_{\mathrm{O}_{2}}{ }^{1 / 2}\right)=(0.144)(0.115)^{1 / 2}=0.049
$$

and, because the range of partial pressures includes both regions of Figure 4.8,

$$
\begin{aligned}
& \Delta V_{\text {ox }}=250 \log \frac{0.049}{0.110}+99 \log \frac{0.110}{0.385} \\
& \Delta V_{\text {ox }}=-142 \mathrm{mV}
\end{aligned}
$$


Pressure. The increase in cell performance obtained by increasing operating pressure from 1 to 10 atmospheres is determined by Equation 4.17:

$$
\begin{aligned}
& \Delta V_{p}=76.5 \log \frac{10}{1} \\
& \Delta V_{p}=+76.5 \mathrm{mV}
\end{aligned}
$$

Design Considerations. The gains realized by increasing cell operating temperature and pressure are significantly less than the losses resulting from operation on leaner oxidant and fuel gases at high utilizations. In fact, the gain of only $6 \mathrm{mV}$ does not warrant increasing the temperature from $650^{\circ}$ to $675^{\circ} \mathrm{C}$. Most of the loss is a result of oxidant partial pressures and could be eliminated by using an inert free gas. This requires an oxygen plant, adding cost and complexity to the molten carbonate fuel cell system. Another option is to pump more oxidant through the cathode to decrease the oxidant utilization to $25 \%$. This improves cell performance by about $29 \mathrm{mV}$ and might also provide a means of cooling the cell.

Operating on rich fuels at lower utilization will also be an improvement. However, the fuel cell efficiency wili suffer at low utilization and, unless the fuel is recovered, the fuel cell system efficiency will be adversely affected. 


\section{REFERENCES CITED}

1. Kordesch, K. V., "25 Years of Fuel Cell Development," J. Electrochem. Soc. 125, 77C-91C (1978) March.

2. Williams, K. R., Ed., An Introduction to Fuel Cells. New York: Elsevier, 1966.

3. McDouga11, A., Fuel Cells. New York: John Wiley, 1976.

4. United Technologies Corporation, "Advanced Technology Fuel Cell Program," EPRI Report EM-576. South Windsor, Conn., 1977.

5. United Technologies Corporation, "Integrated Coal Gasifier/Molten Carbonate Fuel Cell Power Plant Conceptual Design and Implementation Assessment," NASA Report CR 134955, Contract NAS 3-19586. South Windsor, Conn., 1976.

6. Voelker, G. E., "DOE Fuel Cell Program Overview." Paper presented at National Fuel Cell Seminar, San Francisco, July 11-13, 1978.

7. United Technologies Corporation, "Advanced Technology Fuel Cell Program," EPRI Report EM-335. South Windsor, Conn., 1976.

8. Ackerman, J. P., "Mo1ten Carbonate Fuel Cell Systems - Status and Potential." Paper presented at Electrochemical Society Meeting, Philadelphia, May 9-13, 1977.

9. Fickett, A. P., "EPRI Fuel Cell Program." Paper presented at National Fuel Cell Seminar, San Francisco, July 11-13, 1978.

10. United Technologies Corporation, "Advanced Technology Fuel Cell Program" EPRI Report EM-956. South Windsor, Conn., 1978.

11. Camara, E. H., Marianowski, L. G. and Donado, R. A. (assigned to Institute of Gas Technology), "Molten Carbonate Fuel Cell Corrosion Inhibition," U. S. Patent 4,160,067 (1979) July 3.

12. Institute of Gas Technology, "Fuel Cell Research on Second Generation Molten Carbonate Systems," Final Report under U. S. Department of Energy Contract 31-109-38-3552, Chicago, 1977.

13. Janz, G. J., Molten Salt Handbook. New York: Academic Press, 1967.

14. Institute of Gas Technology, "Fuel Cell Research on Second Generation Molten Carbonate System," Topical Report under U. S. Department of Energy Contract DE-AC3-78ET11276, Chicago, 1979. 
15. Hahn, K. W., Tang, T. E. and Camara, E. H., "Effect of Temperature and Pressure on Molten Carbonate Fuel Cell Fuels and Performance." Paper presented at 14 th Intersociety Energy Conversion Engineering Conference, Boston, August 5-10, 1979.

16. Camara, E. H., Tang, T. E., Hahn, K. W. and Benjamin, T. G., "Pressure Effect on Fuel Gas Composition and Molten Carbonate Fuel Cel1 Operation." Paper presented at Molten Carbonate Fuel Cel1 Workshop, Oak Ridge, Tenn., October 31-November 2, 1978.

17. Szymanski, S. T., "A Mathematical Model of the Molten Carbonate Fuel Cell." Paper presented at 150th Electrochemical Society Meeting, Las Vegas, 1976.

18. Rosenquist, T., "A Thermodynamic Study of the Iron, Cobalt, and Nicke1 Sulfides," J. Iron Steel Inst. London 176, 37 (1954) January.

19. Institute of Gas Technology, "Development of Sulfur-Tolerant Components for Second Generation Molten Carbonate Fuel Ce11s," EPRI EM-114, Chicago, 1979.

20. Atomics Internationa1, "Development of a Molten Carbonate Process for Removal of Sulfur Dioxide from Power Plant Stack Gases, Summary Report AI-68-104. Canoga Park, Ca., 1968.

21. General Electric Company, "Development of Molten Carbonate Fuel Cells for Power Generation," Quarterly Report under U. S. Department of Energy Contract DE-AC03-77ET11319, March, 1979.

22. General Electric Company, "Development of Molten Carbonate Fuel Cells for Power Generation," Quarterly Report under U. S. Department of Energy Contract DE-AC03-77ET11319, June, 1979.

23. Kunz, H. R., "Molten Carbonate Fuel Cell Performance." Paper presented at National Fuel Ce11 Seminar, San Francisco, July 11-13, 1978. 
CHAPTER 5. FUEL CELL EFFICIENCY AND HEAT BALANCE

Introduction

A fuel cell converts chemical energy directly into electrical energy without the losses that result from the friction of moving parts, Carnot limitations, and gas expansion. Nevertheless there are inefficiencies in a fuel cell; for example, fuel cell utilization and electronic and ionic conduction rèsistance through components and at contact points are less than $100 \%$, as discussed in Chapter 2. This chapter will discuss how to determine the efficiency of a fuel cell under realistic operating conditions and will develop the necessary equations to be applied to actual fuel cell data. Fuel Cell Efficiency

In the following sections, the efficiency of converting gaseous fuels to $d-c$ power in a fuel cell will be described in terms of thermodynamic, voltage, and current efficiencies. In addition, the efficiency equation will be generalized to account for the presence of conventionally combustible species that do not react electrochemically, such as methane.

Thermodynamic Efficiency. The overall reaction of a fuel cell operating on air and on hydrogen from a hydrocarbon fuel processor is -

$$
\mathrm{H}_{2}+1 / 2 \mathrm{O}_{2} \rightarrow \mathrm{H}_{2}(\mathrm{~g})
$$

The thermodynamic efficiency is defined based on the relationship

$$
\Delta \mathrm{G}_{\mathrm{r}}=\Delta \mathrm{H}_{\mathrm{r}}-\mathrm{T} \Delta \mathrm{S}_{\mathrm{r}}
$$

where the enthalphy change of Equation 5.1, $\Delta \mathrm{H}_{r}$, is the maximum amount of heat energy that can be produced isothermally and isostatically. The Gibbs free energy change, $\Delta G_{r}$, is the maximum amount of energy available for conversion to electricity, and $\mathrm{T} \Delta \mathrm{S}_{\mathrm{r}}$ is the minimum amount of heat produced. Therefore the thermodynamic or maximum efficiency is -

$$
\varepsilon_{\mathrm{Th}} \equiv \frac{\Delta \mathrm{G}_{\mathrm{r}}}{\Delta \mathrm{H}_{\mathrm{r}}}
$$


The appropriate enthalphy change is the lower heating value of hydrogen evaluated at the cell operating conditions of temperature and composition, because only $\mathrm{H}_{2}$ is converted to electric power and the product water is not condensed. The heat of reaction at non-standard-state temperatures is determined by lowering the temperature of the reactants to the standard state, performing the reaction, and raising the temperature of the products back to the original temperature:

$$
\Delta \mathrm{H}_{\mathrm{r}}=\Delta \mathrm{H}_{\mathrm{R}}+\Delta \mathrm{H}_{298}+\Delta \mathrm{H}_{\mathrm{P}}
$$

or

$$
\begin{aligned}
& 298 \\
& \mathrm{~T}
\end{aligned}
$$

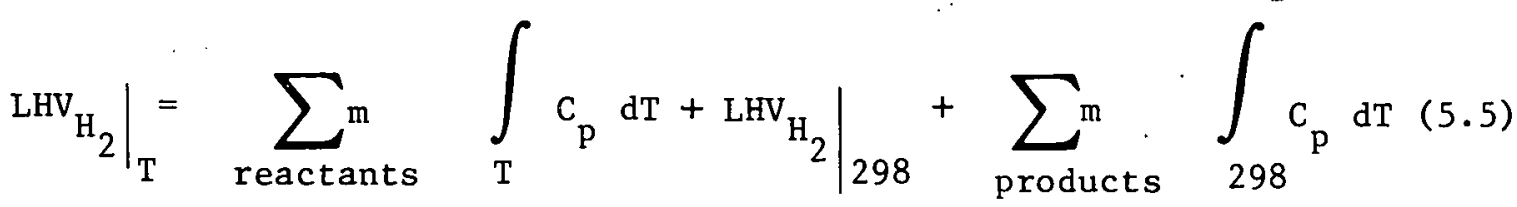

where $\mathrm{m}$ is the stoichiometric coefficient of each component. The integrals of Equation 5.5 can be evaluated by using heat capacity-temperature equations or by using mean heat capacities. ${ }^{5}$ (See Figure A-1 for graphs of mean heat capacities with respect to temperature.) Equation 5.5 can then be witten -

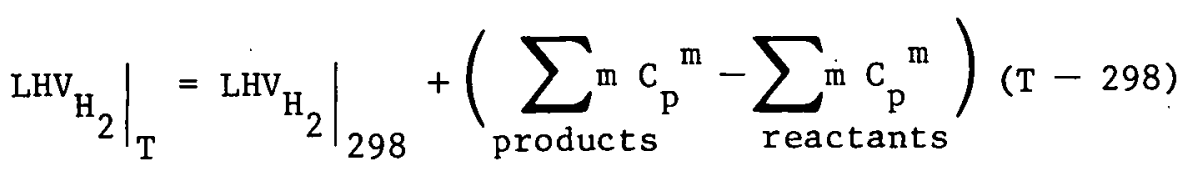

For fuels containing less than $100 \%$ hydrogen,

$$
\Delta \mathrm{H}_{\mathrm{r}}=\mathrm{LHV}_{\mathrm{H}_{2}} \Gamma \mathrm{H}_{2} \mid \mathrm{T}, \mathrm{P} \frac{\mathrm{cal}}{\mathrm{g}-\mathrm{mol} \text { feed gas }}
$$

For ideal gases, enthalphy is unaffected by pressure changes. 
where $\Gamma_{\mathrm{H}_{2}}$ is the mole fraction of hydrogen available in the fuel cell feed or from chemical equilibirium. For the phosphoric acid fuel cell operating at $200^{\circ} \mathrm{C}$, hydrogen available from internal shift and methane equilibria is negligible, so only the feed hydrogen participates in the power production and

$$
\left(\mathrm{r}_{\mathrm{H}_{2}}\right) \text { acid }=\mathrm{X}_{\mathrm{H}_{2}}
$$

In contrast, a molten carbonate fuel cell operates at $650^{\circ} \mathrm{C}$, where the water-gas shift and methane-reforming* reactions supply additional hydrogen as the electrochemical oxidation of hydrogen proceeds:**

$$
\begin{aligned}
& \mathrm{CO}+\mathrm{H}_{2} \mathrm{O} \rightleftarrows \mathrm{H}_{2}+\mathrm{CO}_{2} \\
& \mathrm{CH}_{4}+\mathrm{H}_{2} \mathrm{O} \rightleftarrows 3 \mathrm{H}_{2}+\mathrm{CO}
\end{aligned}
$$

Therefore,

$$
\left(\mathrm{\Gamma}_{\mathrm{H}_{2}}\right)_{\text {carbonate }}=\mathrm{X}_{\mathrm{H}_{2}}+\mathrm{X}_{\mathrm{CO}}+3 \mathrm{X}_{\mathrm{CH}_{4}}
$$

The Gibbs free energy change must also be evaluated at cell operating conditions. Thermodynamic data can be used, but a more convenient approach is to use the Nernst equation to determine the open-circuit voltage. The Gibbs free energy change is then calculated by Equation 5.12:

$$
\Delta G_{r}=-\left.n F E \Gamma_{H_{2}}\right|_{T, P} \frac{c a l}{g-\text { mol feed ga.s }}
$$

This assumes that sufficient water is present to force Equation 5.10 to the right.

Although Equation 5.9 is exothermic and Equation 5.10 is endothermic, the heats of reaction are not included in $\Delta \mathrm{H}_{r}$ because they do not contribute to the electrochemical power production. These effects will be accounted for in a heat balance around the fuel cell and in the total system energy balance and efficiency determination. 
Because $E$ is a function of partial pressure, $\Delta G_{r}$ is a function of the cell operating pressure.

Voltage Efficiency. The discussion of thermodynamic efficiency is based on equilibrium conditions. When a net current is drawn to drive an external load, the inefficiencies discussed in Chapter 2 become important and reduce the cell voltage to a value less than the thermodynamic equilibrium value, $E$. The voltage efficiency is defined as the ratio of the actual cell voltage under load to the theoretical voltage at equilibrium:

$$
\varepsilon_{\mathrm{v}} \equiv \frac{\mathrm{V}}{\mathrm{E}}
$$

Current Efficiency. The efficiency of an electrochemical cell is further reduced if all of the reactants are not converted to products, or if some of the electrons are involved in an alternative reaction such as corrosion. The amount of current produced by a reaction is obtained from Faraday's law:

$$
I_{F}=n F \frac{d f}{d t}
$$

where $d f / d t$ is the molar flow rate of the electrochemical fuel. To minimize diffusion losses that occur at very high conversions, fuel cells operate at less than $100 \%$ utilization. The current produced is related to the amount of fuel actually consumed:

$$
I=n F\left(\frac{d f}{d t}\right) \text { consumed }
$$

The current efficiency is the ratio of the actual current to the current predicted by Equation 5.14:

$$
\varepsilon_{I} \equiv \frac{I}{I_{F}}
$$

The current efficiency is usually reported as total fuel utilization.

Electrochemical Efficiency. The electrochemical efficiency of a fuel cell is the product of the efficiency terms that have been developed:

$$
\varepsilon_{\mathrm{E}} \equiv \varepsilon_{\mathrm{Th}} \varepsilon_{\mathrm{V}} \varepsilon_{\mathrm{I}}
$$

For a cell operating on a gas containing only inerts and electrochemically active species, Equation 5.17 is sufficient to describe the conversion 
of electrochemical fuel to $d-c$ power. The presence of conventionally combustible species requires an additional efficiency term.

Heating Value Efficiency: The product gases from most practical fuel processors will contain varying amounts of inerts and combustible $\mathrm{H}_{2}, \mathrm{CO}$, and $\mathrm{CH}_{4}$, which can be burned in a conventional combustion device, converting all chemical energy into heat energy usable in a heat engine. The fuel cell converts only $\mathrm{H}_{2}$ directly and, at high temperatures, $\mathrm{CO}$ and $\mathrm{CH}_{4}$ indirectly to electricity. The heating value efficiency is defined as the ratio of $\Delta H_{r}$ to the amount of heat energy available from combustion of the fuel gas, that is, the lower heating value.*

$$
\varepsilon_{H} \equiv \frac{\Delta H_{r}}{\Delta H_{c}}
$$

Only species involved in electricity production are included in $\Delta \mathrm{H}_{\mathrm{r}}$, but $\Delta \mathrm{H}_{\mathrm{c}}$ includes all combustible species and is determined from the thermodynamics of mixtures.

$$
\Delta H_{c}=\left.\sum_{i} L_{i} x_{i}\right|_{T} \frac{c a l}{g-m o l \text { feed gas }}
$$

Again, the lower heating value is used because the combustion product water is not condensed in the fuel cell.

If a fuel gas containing $\mathrm{H}_{2}, \mathrm{CO}$, and $\mathrm{CH}_{4}$ is burned, the following combustion reactions occur:

$$
\begin{aligned}
& \mathrm{XCO}+\frac{\mathrm{X}}{2} \mathrm{O}_{2} \rightarrow \mathrm{X} \mathrm{CO} \\
& \mathrm{YH}+\frac{\mathrm{Y}}{2} \mathrm{O}_{2} \rightarrow \mathrm{YH}_{2} \mathrm{O} \\
& \mathrm{Z} \mathrm{CH}_{4}+2 \mathrm{ZO}_{2} \rightarrow \mathrm{Z} \mathrm{CO}_{2}+2 \mathrm{Z} \cdot \mathrm{H}_{2} \mathrm{O}
\end{aligned}
$$

See Appendix A for a tabulation of heating values and a discussion of the relationships between $\Delta G, \Delta H, T \Delta S$, and higher and lower heating values. 
where $X, Y$, and $Z$ are mole fractions of $\mathrm{CO}, \mathrm{H}_{2}$, and $\mathrm{CH}_{4}$ in the feed gas, respectively. Applying Equation 5.4 to the combustion reactions gives -

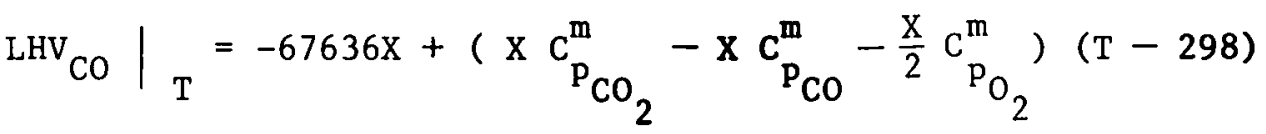

$$
\begin{aligned}
& \left.{ }^{\mathrm{LHV}} \mathrm{H}_{2}\right|_{\mathrm{T}}=-57798 \mathrm{Y}+\left(\mathrm{Y} \mathrm{C}_{\mathrm{P}_{\mathrm{H}_{2} \mathrm{O}}^{\mathrm{m}}}^{\mathrm{m}}-\mathrm{Y} \mathrm{C} \mathrm{P}_{\mathrm{P}_{2}}^{\mathrm{m}}-\frac{\mathrm{Y}}{2} \mathrm{C}_{\mathrm{P}_{\mathrm{O}_{2}}}^{\mathrm{m}}\right)(\mathrm{T}-298)
\end{aligned}
$$

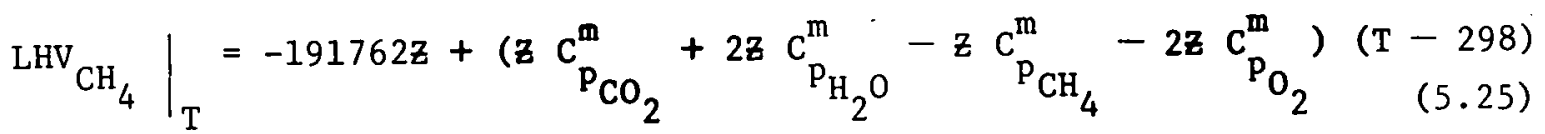

Equation 5.19 becomes -

$$
\begin{aligned}
& \Delta H_{C}=-(67636 \mathrm{X}+57798 \mathrm{Y}+191762 \mathrm{z}) \\
& -\left[Z C_{\mathrm{p}_{\mathrm{CH}_{4}}^{\mathrm{m}}}^{\mathrm{m}}+\mathrm{Y} \mathrm{C}_{\mathrm{p}_{\mathrm{H}_{2}}^{\mathrm{m}}}+\mathrm{X} \mathrm{C}_{\mathrm{p}_{\mathrm{CO}}}^{\mathrm{m}}+\left(2 \mathrm{z}+\frac{\mathrm{X}}{2}+\frac{\mathrm{Y}}{2}\right) \mathrm{C}_{\mathrm{P}_{\mathrm{O}_{2}}}^{\mathrm{m}}\right](\mathrm{T}-298)
\end{aligned}
$$

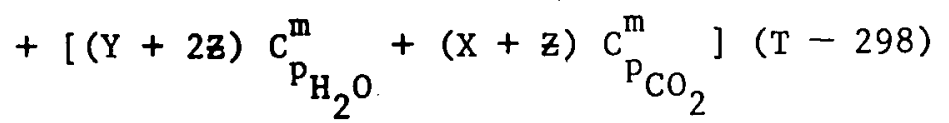

Fuel Cell Efficiency. The fuel cell efficiency describes the conversion of chemical energy in the feed gas to $d-c$ power and is defined as -

$$
\varepsilon_{\mathrm{FC}} \equiv \varepsilon_{\mathrm{E}} \varepsilon_{\mathrm{H}}
$$

or

$$
\varepsilon_{F C}=\left(\frac{\Delta G}{\Delta H_{r}}\right)\left(\frac{V}{E}\right) \quad\left(\frac{I}{I_{F}}\right) \cdot\left(\frac{\Delta H_{r}}{\Delta H_{C}}\right)
$$

Only the fuel cell power section of a fuel cell system is described by $\varepsilon_{F C}$. The fuel processor, power conditioner, and waste hrat utilization are not included. 


\section{Sample Calculations}

This section will illustrate in detail the application of the efficiency equations (summarized in Table 5.1) to actual phosphoric acid and molten carbonate fuel cell data at various operating conditions.

\section{Table 5.1. SUMMARY OF EFFICIENCY EQUATIONS}

$$
\begin{aligned}
& \text { V, volts Load } \\
& \text { E, volts - Open-circuit } \\
& \Delta G_{\mathrm{r}}, \quad \text { cal/g-mol feed gas } \quad-\left.\mathrm{nFE} \Gamma_{\mathrm{H}_{2}}\right|_{\mathrm{T}, \mathrm{P}} \\
& \Delta \mathrm{H}_{\mathrm{r}} \text {, cal/g-mo1 feed gas. } \quad \mathrm{LHV}_{\mathrm{H}_{2}} \mid \mathrm{T}^{\Gamma_{\mathrm{H}}} \\
& \Delta \mathrm{H}_{\mathrm{C}}, \quad \mathrm{cal} / \mathrm{g}-\mathrm{mol} \text { feed gas }\left.\quad \operatorname{LLHV}_{\mathrm{i}} \mathrm{X}_{\mathrm{i}}\right|_{\mathrm{T}} \\
& \varepsilon_{v} \text {, voltage efficiency } \quad \mathrm{V} / \mathrm{E} \\
& \varepsilon_{I} \text {, current efficiency Utilization } \\
& \varepsilon_{T h} \text {, thermodynamic efficiency. } \Delta G_{r} / \Delta H_{r} \\
& \varepsilon_{E} \text {, electrochemical efficiency . } \quad \varepsilon_{V} \varepsilon_{I} \varepsilon_{T h} \\
& E_{H} \text {, heating value efficiency } \quad \Delta H_{r} / \Delta H{ }_{C} \\
& \varepsilon_{F C} \text {, fuel cell efficiency } \varepsilon_{E} \varepsilon_{H}
\end{aligned}
$$

Phosphoric Acld Fuel Cell. A cell operating at $9.5 \mathrm{~atm}, 190^{\circ} \mathrm{C}, 0.688$ volt, $323 \mathrm{~mA} / \mathrm{cm}^{2}$ and $85 \%$ fuel utilization on air and the fuel gas described in Table 5.2 will be used as an example. 
Table 5.2. FUEL GAS COMPOSITION AND THERMODYNAMIC VALUES FOR PHOSPHORIC ACID FUEL CELL SAMPLE EFFICIENCY CALCULATION, $1 \mathrm{atm,} 190^{\circ} \mathrm{C}$

\begin{tabular}{|c|c|c|c|}
\hline & $\left(P_{i}\right)_{\text {in }}$ & $\begin{array}{l}\mathrm{LHV} 25^{\circ} \mathrm{C} \\
\mathrm{ca} 1 / \mathrm{g} \text {-mol }\end{array}$ & $\begin{array}{l}\mathrm{C}_{\mathrm{p}}^{\mathrm{m}} 25-190^{\circ} \mathrm{C} \\
\mathrm{ca} 1 / \mathrm{g}-\mathrm{mo} 1{ }^{\circ} \mathrm{C}\end{array}$ \\
\hline $\mathrm{H}_{2}$ & 0.639 & $\begin{array}{c}-57798 \\
-\end{array}$ & 6.9 \\
\hline $\mathrm{CO}$ & 0.014 & -67636 & 7.0 \\
\hline $\mathrm{CO}_{2}$ & 0.150 & 0 & 9.7 \\
\hline $\mathrm{H}_{2} \mathrm{O}$ & 0.197 & 0 & 8.15 \\
\hline $\mathrm{CH}_{4}$ & 0 & -191762 & 9.5 \\
\hline $\mathrm{O}_{2}$ & $\dot{0}$ & 0 & 7.2 \\
\hline
\end{tabular}

The open-circuit potential is -

$$
E=E^{O}+\frac{R T}{2 F} \ln \frac{P_{H_{2}} P_{O_{2}} 1 / 2}{P_{\mathrm{H}_{2} \mathrm{O}}}
$$

where ${ }^{*}$

$$
\mathrm{E}^{\circ}=-\left.\frac{\Delta \mathrm{G}^{\circ}}{\mathrm{nF}}\right|_{190^{\circ} \mathrm{C}}=\frac{52789}{2(23060)}=1.145 \mathrm{~V}
$$

Substituting the partial pressures and $\mathrm{E}^{\mathrm{O}}$ into Equation 5.29 yields $\mathrm{E}=1.175 \mathrm{~V}$. Then,

$$
\varepsilon_{\mathrm{v}}=\frac{\mathrm{V}}{\mathrm{E}}=\frac{0.668}{1.175}=0.586
$$

Because the fuel utilization is $85 \%$,

$$
\varepsilon_{I}=0.85
$$

Determination of $\varepsilon_{T h}$ requires calculation of $\Delta G_{r}$ by Equations 5.5 and 5.12:

$$
\Delta G_{\mathrm{r}}=-\mathrm{nFE} \Gamma_{\mathrm{H}_{2}}=-2(23060)(1.175)(0.639)=-34628 \frac{\mathrm{cal}}{\mathrm{g}-\mathrm{mol} \text { feed gas }}
$$

* See Table A-6 for a tabulation of $\Delta G^{\circ}$ and $E^{\circ}$ as functions of temperature. 
and $\Delta \mathrm{H}_{\mathrm{r}}$ by Equations 5.6 and 5.7 .

The lower heating value of hydrogen at $190^{\circ} \mathrm{C}$ is obtained by -

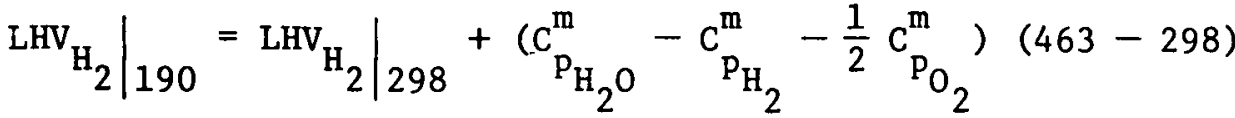

$$
\begin{aligned}
& =-57798+(8.15-6.9-3.6)(165)=-58186 \frac{\mathrm{cal}}{\mathrm{g}-\mathrm{mol} \mathrm{H}_{2}}
\end{aligned}
$$

For the acid cell,

$$
\Gamma_{\mathrm{H}_{2}}=\mathrm{x}_{\mathrm{H}_{2}}=0.639 \frac{\mathrm{mol} \mathrm{H}_{2}}{\text { mol feed gas }}
$$

thus,

$$
\Delta \mathrm{H}_{\mathbf{r}}=-58186(0.639)=-37181 \frac{\mathrm{cal}}{\mathrm{g}-\mathrm{mol} \text { feed gas }}
$$

Then

$$
\varepsilon_{\mathrm{Th}}=\frac{\Delta \mathrm{G}_{\mathrm{r}}}{\Delta \mathrm{H}_{\mathrm{r}}}=\frac{-34628}{-37181}=0.931
$$

and the electrochemical efficiency of conversion of hydrogen to electric power is -

$$
\varepsilon_{E}=\varepsilon_{T h} \varepsilon_{V} \varepsilon_{I}=(0.931)(0.586)(0.85)=0.464
$$

Calculation of the heating value efficiency requires determining the heat of combustion using Equation 5.26:

$$
\begin{aligned}
\Delta \mathrm{H}_{\mathrm{C}}= & -[67636(0.014)+57798(0.0639)] \\
& -[0.639(6.9)+0.014(7.0)+0.327(7.2)] 165 \\
& +[0.639(8.15)+0.014(9.7)] 165 \\
\Delta \mathrm{H}_{\mathrm{C}}= & -38129 \frac{\mathrm{cal}}{\mathrm{g}-\mathrm{mol} \text { feed gas }}
\end{aligned}
$$

The heating value efficiency is -

$$
\varepsilon_{H}=\frac{\Delta{ }_{r}}{\Delta H_{C}}=\frac{-37181}{-38129}=0.975
$$

The value of $\varepsilon_{H}$ is close to unity because the combustible fraction of 
the fuel gas is mostly hydrogen, which participates in the electrochemical reaction.

Finally, the efficiency of converting chemical energy in the fuel feed to electrical energy is -

$$
\varepsilon_{\mathrm{FC}}=\varepsilon_{E \varepsilon_{\mathrm{H}}}=(0.464)(0.975)=0.45
$$

Molten Carbonate Fuel Cel1. Table 5.3 describes the fuel gas fed to the molten carbonate fuel cell anode from the air-blown coal gasifier. At $650^{\circ} \mathrm{C}, 1 \mathrm{~atm}, 75 \%$ fuel utilization, and $160 \mathrm{~mA} / \mathrm{cm}^{2}, 0.745$ volt is generated with an oxidant gas composed of $70 \%$ air and $30 \% \mathrm{CO}_{2}$ at $50 \%$ utilization. The open-circuit voltage is -

$$
\begin{aligned}
& E=1.019+\frac{R T}{2 F} \ln \frac{0.186}{0.114(0.078)}+\frac{R T}{2 F} \ln \left[0.30(0.15)^{1 / 2}\right] \\
& E=1.054 \text { volt }
\end{aligned}
$$

The voltage efficiency is -

$$
\varepsilon_{\mathrm{v}}=\frac{0.745}{1.054}=0.707
$$

and the current efficiency is equivalent to the fuel utilization:

$$
\varepsilon_{I}=0.75
$$

Because the fuel gas contains $\mathrm{H}_{2}, \mathrm{CO}$, and $\mathrm{CH}_{4}$,

$$
\Gamma_{\mathrm{H}_{2}}=0.186+0.14+3(0.03)=0.416 \frac{\mathrm{g}-\mathrm{mol} \mathrm{H}_{2} \text { available }}{\mathrm{g}-\mathrm{mol} \text { feed gas }}
$$

Therefore,

$$
\Delta \mathrm{G}_{\mathrm{r}}=-\mathrm{nF}(1.054)(0.416)=-20222 \frac{\mathrm{cal}}{\mathrm{g}-\mathrm{mol} \text { feed gas }}
$$

and

$$
\begin{aligned}
& \Delta \mathrm{H}_{\mathrm{r}}=0.416[-57798-625(7.05+3.85)+625(8.75)] \\
& \Delta \mathrm{H}_{\mathrm{r}}=-24603 \mathrm{ca} / \mathrm{g}-\mathrm{mol} \text { feed gas }
\end{aligned}
$$


Then

$\varepsilon_{\mathrm{Th}}=\frac{-20222}{-24603}=0.822$

and

$$
\varepsilon_{E}=(0.822)(0.707)(0.75)=0.436
$$

The heating value efficiency is determined through Equations 5.18 and 5.26:

$$
\begin{aligned}
& \Delta \mathrm{l}_{\mathrm{C}}=-[67636(0.14)+57798(0.186)+191762(0.03)] \\
& -625[0.03(12.6)+0.186(7.05)+0.14(7.3)+(0.06+.07+.093)(7.7)] \\
& +625[(0.186-0.06)(8.75)+(0.14+0.03)(11.2)] \\
& \Delta \mathrm{H}_{\mathrm{C}}=-26205 \frac{\mathrm{cal}}{\mathrm{g}-\mathrm{mol} \text { feed gas }}
\end{aligned}
$$

and

$$
\varepsilon_{H}=\frac{-24603}{-26205}=0.939
$$

\begin{tabular}{|c|c|c|c|}
\hline & $\left(\mathrm{P}_{\mathrm{i}}\right)_{\mathrm{in}}$ & $\begin{array}{l}\mathrm{LHV} 25^{\circ} \mathrm{C} \\
\mathrm{cal} / \mathrm{g}-\mathrm{mol}\end{array}$ & $\begin{array}{l}\mathrm{C}^{\mathrm{m}} 25-650^{\circ} \mathrm{C} \\
\mathrm{c} \mathrm{g}_{1 / \mathrm{g}-\mathrm{mo}}{ }^{\circ} \mathrm{C}\end{array}$ \\
\hline $\mathrm{H}_{2}$ & 0.186 & -57798 & 7.05 \\
\hline $\mathrm{CO}$ & 0.140 & -67636 & 7.30 \\
\hline $\mathrm{CO}_{2}$ & 0.114 & 0 & 11.20 \\
\hline $\mathrm{H}_{2} \mathrm{O}$ & 0.078 & 0 & 8.75 \\
\hline $\mathrm{CH}_{4}$ & 0.030 & -191762 & 12.60 \\
\hline $\mathrm{N}_{2}$ & 0.460 & 0 & 7.25 \\
\hline $\mathrm{O}_{2}$ & 0 & 0 & 7.70 \\
\hline
\end{tabular}

Finally,

$$
\varepsilon_{\mathrm{FC}}=0.436(0.939)=0.409
$$

Table 5.3. FUEL GAS COMPOSITION AND THERMODYNAMIC VALUES FOR MOLTEN CARBONATE FUEL CELL SAMPLE EFFICIENCY CALCULATION, $1 \mathrm{atm,} 650^{\circ} \mathrm{C}$ 
The preceding techniques and the equations in Table 5.1 have been applied to actual phosphoric acid and molten carbonate fuel cell data at various temperatures, pressures, and fuel compositions. Although the efficiency values presented are based on published data, they are intended only to demonstrate trends. Cell operation at different conditions requires determination of an efficiency specific to those conditions.

Phosphoric Acid. Table 5.4 summarizes the results of the efficiency calculations for the phosphoric acid fuel cell operating at the conditions ${ }^{6,7}$ described in Table 5.5. Because the operating temperature of phosphoric acid fuel cells is 1 ow $\left(190^{\circ} \mathrm{C}\right.$ to $\left.218^{\circ} \mathrm{C}\right)$, and because the exit temperature from from the fuel processing section is higher than the cell operating temperature,,$^{\circ}$ changes in the fuel inlet composition have been neglected. The necessary values of $\left(C_{p}\right)_{i}$ were obtained from Figure $A-1$ and values of $\Delta G^{\circ}$ and $\Delta E^{\circ}$ from Table A-6.

As the cell temperature is increased, the results show that $\varepsilon_{T h}$ decreases but $\varepsilon_{\mathrm{V}}$ increases. The net result is an increase in cell efficiency. Increasing pressure also improves cell efficiency because both the voltage and thermodynamic efficiencies increase.

Molten Carbonate. The results of the molten carbonate efficiencies calculations are summarized in Table 5.6. Common conditions ${ }^{9}$ are listed in Table 5.7. Changes in the equilibrium fuel inlet composition that result from temperature and pressure changes were considered in the calculation and are reflected in $\mathrm{E}, \Delta \mathrm{G}_{\mathrm{r}}, \Delta \mathrm{H}_{\mathrm{r}}$, and $\Delta \mathrm{H}_{\mathrm{C}}$ and, consequently, $\varepsilon_{\mathrm{V}}, \varepsilon_{\mathrm{Th}}$, and $\varepsilon_{\mathrm{H}} \cdot$

The molten carbonate fuel cell efficiencies presented in Table 5.6 demonstrate the effect of changing gas composition and the importance of adequate fuel humidification to prevent methane formation. As pressure is increased for a cell operating on the simulated product gas from an air-blown coal gasifier, the methane concentration varies only slightly for the cases under consideration because of the increase in fuel dew point.

Because of insufficient humidification ${ }^{\star}$ and the resulting consumption of hydrogen to form methane, fuel cell efficiency does not increase with pressure for the cells operating on simulated reformed methane.

The dew points of the data in Table 5.6 were chosen to prevent carbon formation, not to prevent methane formation. 10

INSTITUTE OF G A S O T T E C H N O L O G Y


Table 5.4. SUMMARY OF PHOSPHORIC ACID FUEL CELL EFFICIENCY CALCULATIONS

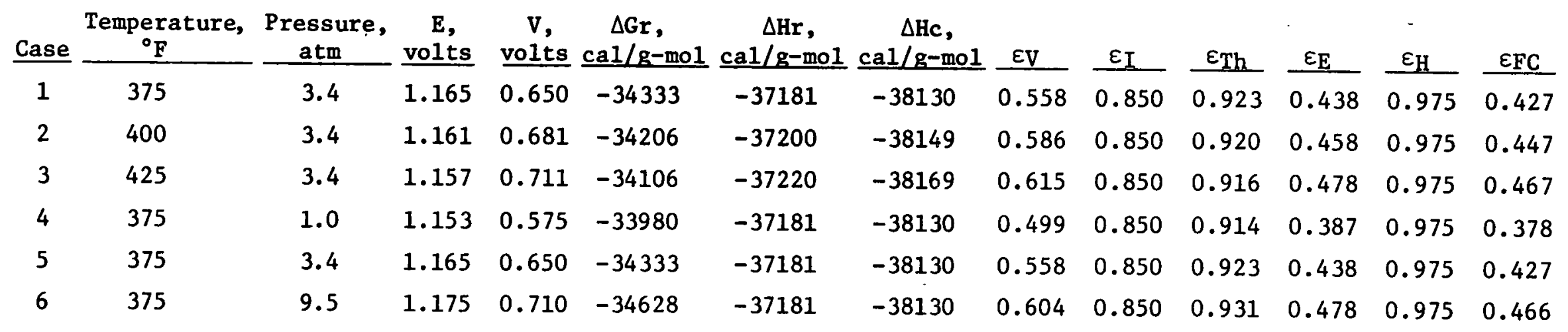

Table 5.5. CELL OPERATING CONDITIONS FOR TABLE 5.4

Fue1 Composition, \%

$\begin{array}{lc}\mathrm{H}_{2} & 63.9 \\ \mathrm{CO}_{2} & 15.0 \\ \mathrm{CO} & 1.4 \\ \mathrm{H}_{2} \mathrm{O} & 19.7 \\ \mathrm{\Gamma H}_{2} & 0.639\end{array}$.

Fuel Utilization, \% $\quad 85.0$

Oxidant Composition, \% Air $\quad 100.0$

Oxidant Utilization, $\% \quad 70.0$

Current Density, $\mathrm{mA} / \mathrm{cm}^{2} \quad 323.0$ 
Table 5.6. SUMMARY OF MOLTEN CARBONATE FUEL CELL EFFICIENCY CALCULATIONS

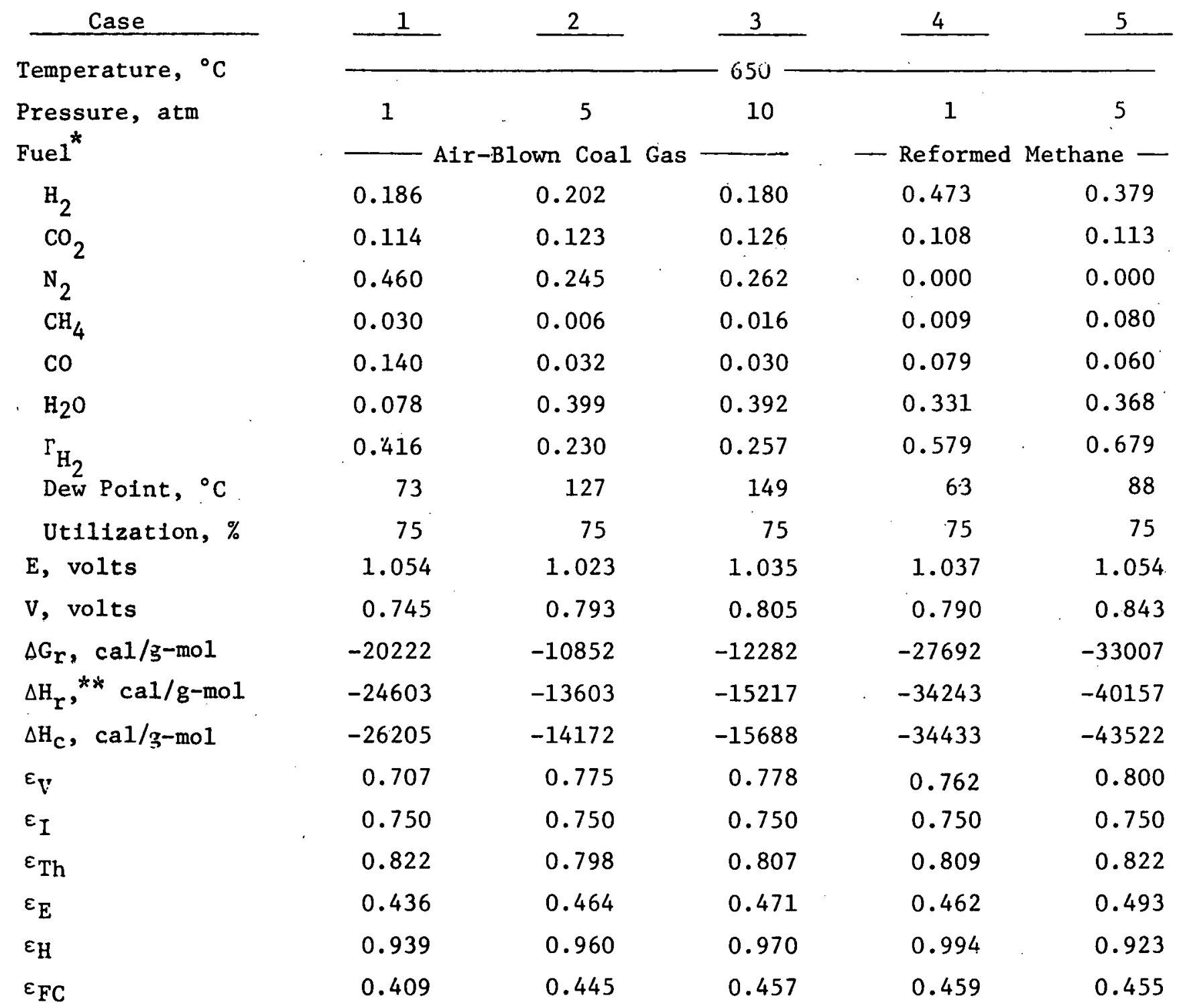

\footnotetext{
‡ Composttions listed are calculated equilibrium mole fractions at cell conditions. **

Both $\mathrm{CO}$ and $\mathrm{CH}_{4}$ are considered sources of $\mathrm{H}_{2}$, i.e., the fuel gas is always in shift and methane equilibrium.
} 
Table 5.7 CELL OPERATING CONDITIONS FOR TABLE 5.6

Oxidant Composition, \%

$\begin{array}{lr}\text { Air } & 70 \\ \mathrm{CO}_{2} & 30 \\ \text { zation, \% } & 50 \\ \text { ty, } \mathrm{mA} / \mathrm{cm}^{2} & 160\end{array}$

\section{Fue1 Ce11 Heat Balance}

The heat balance of a fuel cell can be determined from the same concepts used to develop the efficiency equations. Figure 5.1 and Equation 5.33 summarize the heat balance. The lower heating values of the inlet and exit streams are easily calculated if the compositions are known (Appendix A).

$$
\mathrm{LHV}_{\text {in }}=\mathrm{W}_{\mathrm{e}}+\mathrm{Q}+\mathrm{LHV}_{\text {out }}
$$

The electrical work obtained is related to the efficiencies by Equation 5.34, where $\varepsilon_{V}$ and $\varepsilon_{I}$ account for $i R$, polarization, and utilization losses:

$$
W_{e}=\varepsilon_{V} \varepsilon_{I} \Delta G_{r}
$$

$$
Q=\text { Heat Rejected (Heat of Reaction, iR Heat) }
$$

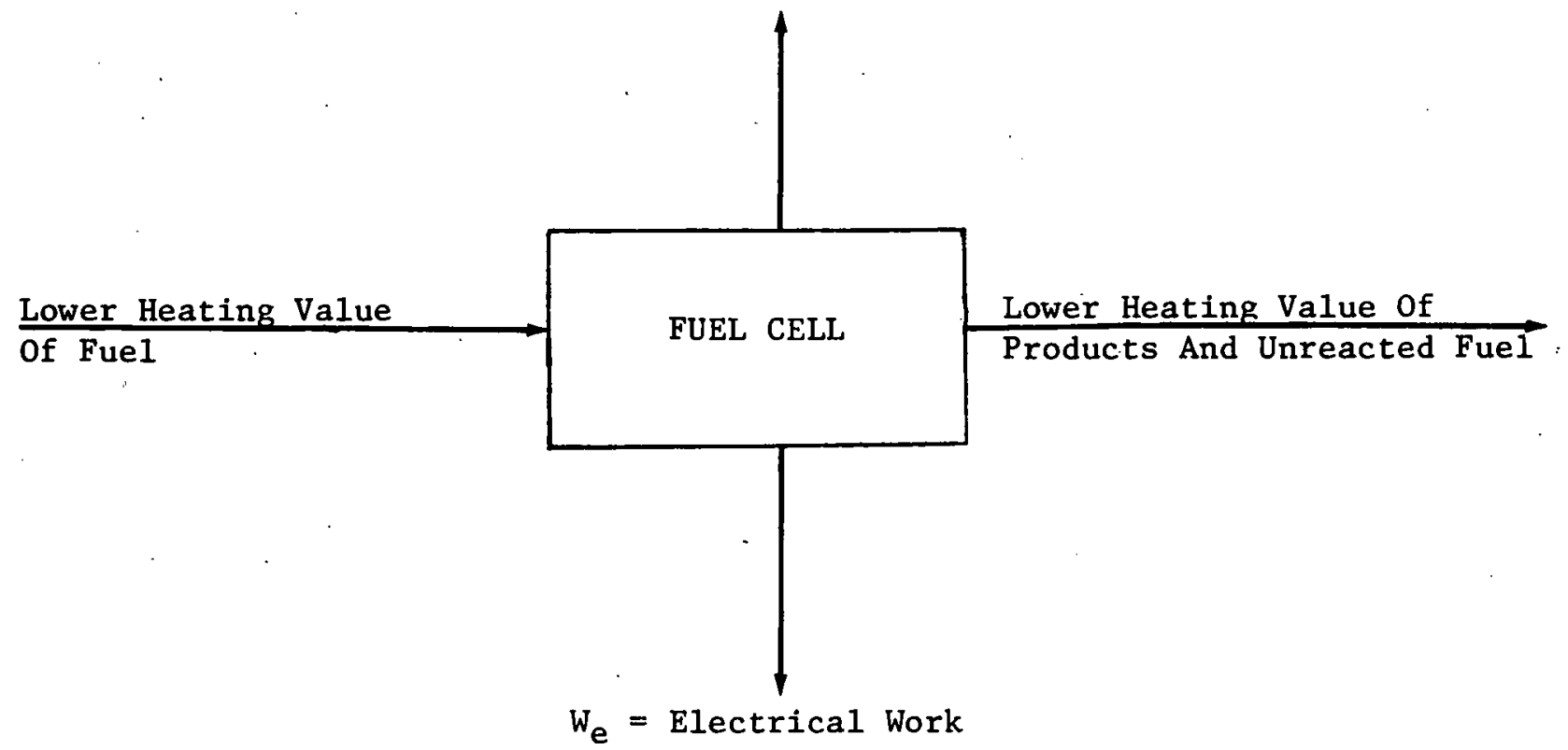

Figure 5.1. FUEL CELL HEAT BALANCE 
The portion of the heat rejected, which is due to $i R\left(Q_{1}\right)$, is equal to the difference between the maximum work avallable $\left(\Delta G_{r}\right)$ and the actual work obtained. For less than $100 \%$ fuel utilization,

$$
\mathrm{Q}_{1}=\varepsilon_{\mathrm{r}} \Delta \mathrm{G}_{\mathrm{r}}-\mathrm{W}_{\mathrm{e}}
$$

Combining Equations 2.2, 5.13, 5.34, and 5.35 -

$$
Q_{1}=\varepsilon_{I} \Delta G_{\mathbf{r}}\left(1-\varepsilon_{V}\right)
$$

or

$$
\mathrm{Q}_{1}=\mathrm{nF} \varepsilon_{\mathrm{I}}(\mathrm{V}-\mathrm{E})
$$

The contribution of the electrochemical heat of reaction to the heat rejected $\left(Q_{2}\right)$ is obtained from Equation 5.2. Agaln, for 1 es8 than $100 \%$ fuel utilization -

$$
Q_{2}=\varepsilon_{I}(-T \Delta S)
$$

or, combining Equations 2.2, 5.2, 5.3, and 5.37,

$$
Q_{2}=\varepsilon_{I}\left(\Delta G_{\mathbf{r}}-\Delta \mathbf{H}_{\mathbf{r}}\right)
$$

or

$$
Q_{2}=\Delta H_{r} \varepsilon_{I}\left(\varepsilon_{T h}-1\right)
$$

or

$$
Q_{2}=\frac{-\Delta H_{r}}{\varepsilon_{v}} \quad\left(\varepsilon_{I}+\varepsilon_{E}\right)
$$

The total heat refected and avallable for use in a bottoming cycle or cogeneration is Q:

$$
Q=Q_{1}+Q_{2}
$$

or, combining Equations 5.3, 5.37, and 5.39 with 5.41

$$
Q=\varepsilon_{I}\left(n F V-\Delta H_{r}\right)
$$

but

$$
\varepsilon_{I}=\frac{I}{n F d f / d t}
$$

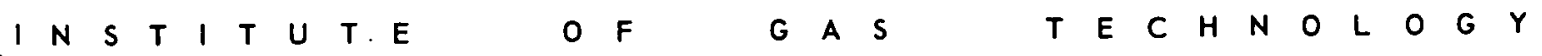


Therefore, the heat release per mole of fuel in the feed gas is -

$$
Q=\frac{I}{n F d f / d t}\left(n F V-\Delta H_{r}\right)
$$

and the total heat rejected is -

$$
Q^{\prime} \text { per second }=I\left(V-\frac{\Delta H_{r}}{n F}\right)
$$

The heat rejected can be used to improve the system efficiency, which is discussed in the next chapter. 
1. Berger, C., Ed., Handbook of Fuel Cell Technology. Englewood Cliffs, N.J.: Prentice Hall, 1968.

2. Bockris, J. 0. M. and Srinvasan, S., Fuel Cells: Their Electrochemistry. New York: McGraw-Hill, 1969.

3. Sutton, G. W., Ed., Direct Energy Conversion. New York: McGraw-Hill, 1966.

4. Soo, S. L., Direct Energy Conversion. Englewood Cliffs, N. J. : Prentice Ha11, 1969.

5. Smith, J. M. and Van Ness, H. C., Introduction to Chemical Engineering Thermodynamics. New York: McGraw-Hil1, 1959.

6. Johnson, W. H., "Improvement of Fuel Cell Technology Base," UTC Technical Progress Report FCR-1809, Contract ET-76-C-03-1196. South Windsor, Conn., April, 1978.

7. Johnson, W. H., "Phosphoric Acid Technology Improvement Program." Paper presented at National Fuel Cell Seminar, San Francisco, July 11-13, 1978.

8. Catalytica Associates, Inc., "Assessment of Fuel Processing Alternatives for Fuel Cell Power Generation," EPRI Report EM-570. Palo Alto, Ca., 1977.

9. Institute of Gas Technology, "Fuel Cell Research on Second Generation Molten Carbonate Fuel Cell Systems," Topical Report under U.S. Department of Energy Contract DE-AC03-78ET11276. Chicago, 1979.

10. Jarvi, G. A. and Vasil, D. R., Institute of Gas Technology, personal communication, October 10, 1979. 
CHAPTER 6. FUEL CELL SYSTEM EFFICIENCY

Fuel Cel1 System Efficiency

The preceding discussion considered only the fuel cell power section of the complete system, shown in Figure 6.1, which consists of a fuel processor, a fuel cell, a power conditioner, and an optional bottoming cycle or cogeneration scheme.

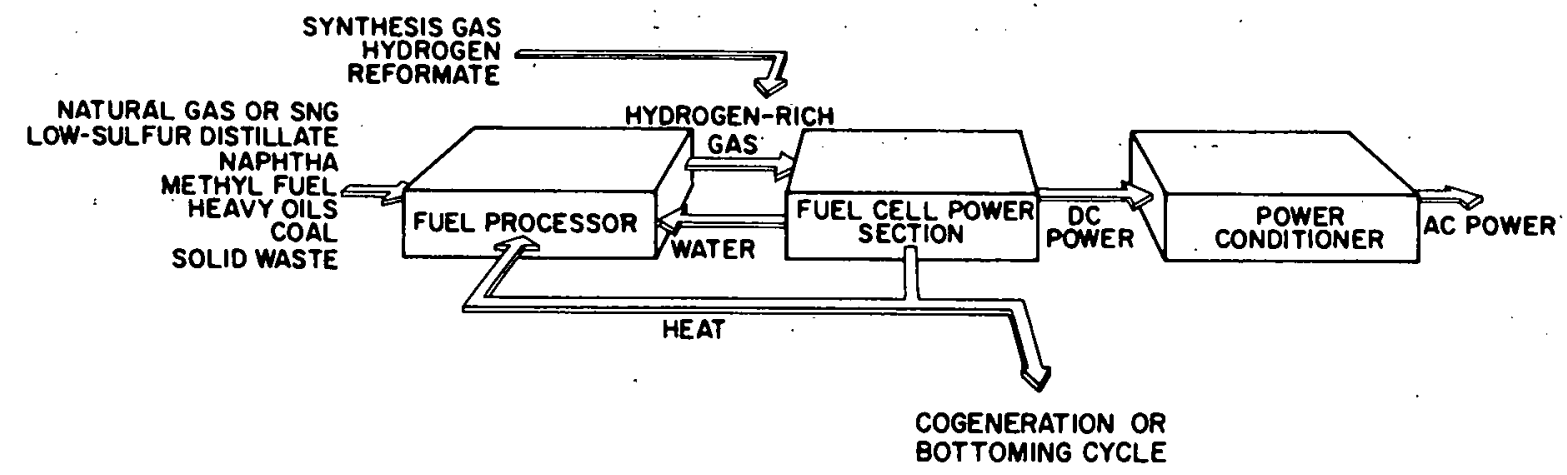

A79051244

Figure 6.1. COMPLETE FUEL CELL POWER PLANT ${ }^{1}$

The overall efficiency for a system without waste heat utilization is -

$$
\varepsilon_{S}=\varepsilon_{F P} \varepsilon_{F C} \varepsilon_{P C}
$$

where

$$
\begin{aligned}
& \varepsilon_{F P} \equiv \frac{\text { LHV gaseous fuel from fuel processor to fuel cell }}{\text { HHV raw fuel into fuel processor }} \\
& \varepsilon_{F C} \equiv \frac{d-c \text { power produced }}{\text { LHV gaseous fuel to fuel cell }} \\
& \varepsilon_{P C} \equiv \frac{a-c \text { power }}{d-c \text { power }} \\
& \varepsilon_{S} \equiv \frac{a-c \text { power }}{\text { HHV raw fuel into fuel processor }}
\end{aligned}
$$


Additional energy can be recovered in the system by integrating a bottoming cycle to produce additional electricity. For a system located onsite, that is, close to the point of electricity consumption, system efficiency can be increased even more by using the remaining heat for generating steam, heating water for domestic use, space heating, or direct heating of an industrial process. Because the fuel cell operating temperature is independent of power output, the quality of the waste heat is constant. For a system employing waste heat utilization, the fuel cell system efficiency becomes -

$$
\varepsilon_{S / H}=\frac{\text { fuel cell a-c }+ \text { bottoming cycle a-c }+ \text { cogeneration Btu's }}{\text { HHV raw fuel into fuel processor }}
$$

Commonly quoted design system efficiencies for fuel cell power plants are listed in Table 6.1. The 150 to $600-\mathrm{MW}$ central power plant does not include a cogeneration scheme because it is not located close to a market for the waste heat. However, a bottoming cycle is included. On the other hand, the onsite system provides the possibility of total heat recovery.

Table 6.1. DESIGN SYSTEM EFFICIENCIES FOR FUEL CELL POWER PLANTS ${ }^{2}$

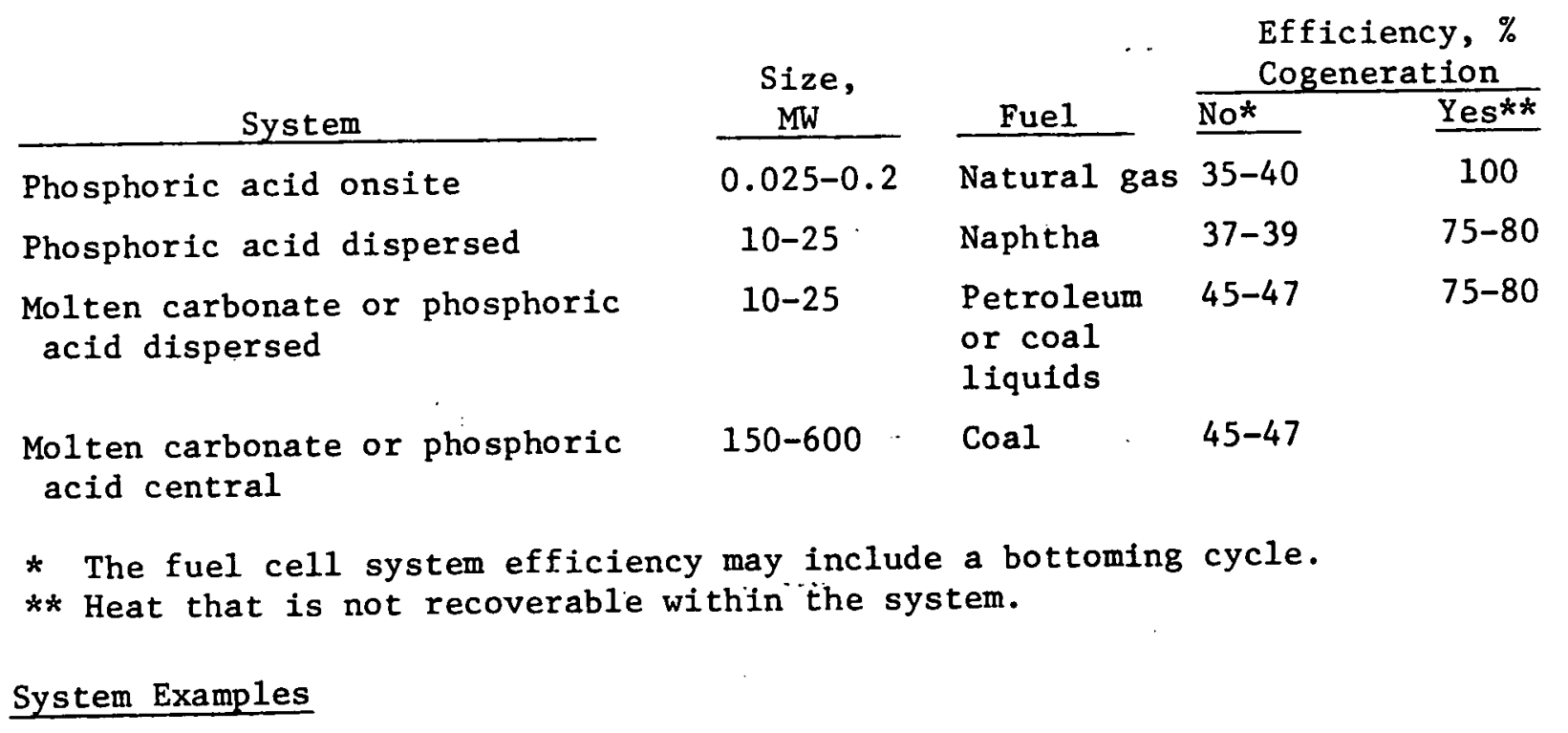

A detailed discussion of fuel cell system integration and heat recovery is not within the scope of this document and is contalned in many studies. ${ }^{1-12}$ Therefore, only a few examples will be presented.

Air-Blown Coal Gasifier/Molten Carbonate Fuel Cell/Bottoming Cycle. ${ }^{5}$ Figure 6.2 shows the energy balance and simplified flcwsheet for a molten carbonate fuel cell integrated with an air-blown coal gasifier and a bottoming cycle. The mass balance is summarized in Table 6.2. The efficiency summary,

I N S T I T UTE TE OF G A S O T E C H N O L O G Y


based on higher heating values, is presented in Table 6.3; it shows that system efficiency is increased from $33.8 \%(10098 \mathrm{Btu} / \mathrm{kWh})$ to $49.6 \%(6881 \mathrm{Btu} / \mathrm{kWh})$ by the integration of the bottoming cycle, which operated at $40 \%$ efficiency.

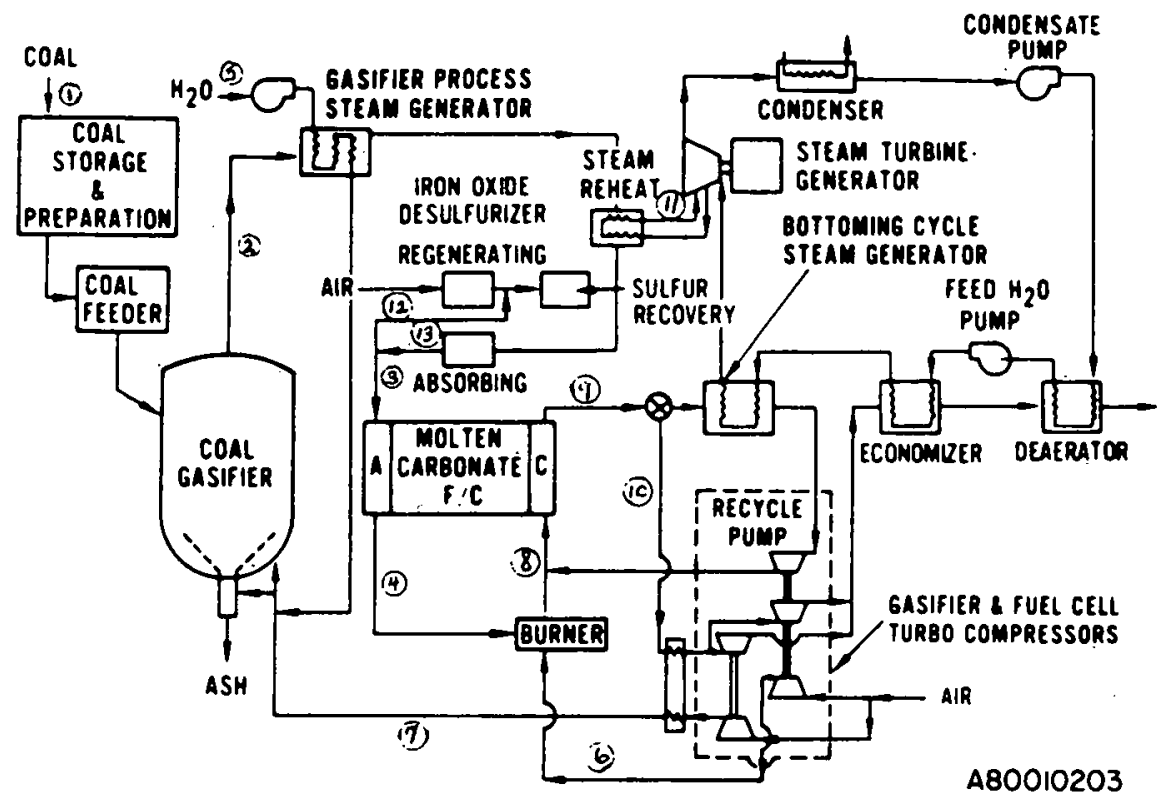

Figure 6.2a. AIR-BLOWN COAL GASIFIER/MOLTEN CARBONATE FUEL CELL/BOTTOMING CYCLE - FLOW SCHEMATIC 5

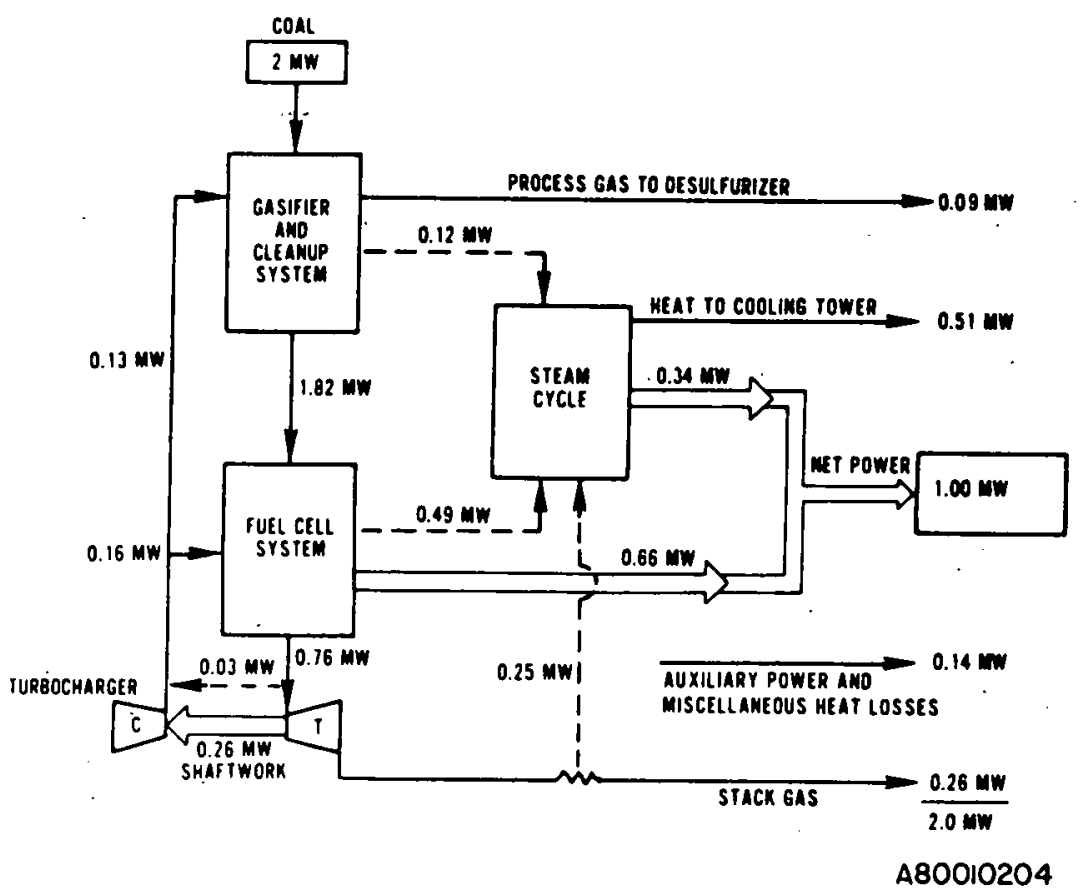

Figure 6.2b. AIR-BLOWN COAL GASIFIER/MOLTEN CARBONATE FUEL CELL/BOTTOMING CYCLE - ENERGY BALANCE. 
Table 6.2. MASS BALANCE FOR THE SYSTEM IN FIGURE 6.2

$-1$

Stream \begin{tabular}{c} 
Temp, \\
$\circ \mathrm{F}$ \\
\hline
\end{tabular} Pres, Composition (lb-mol/hr) strean

59

psia

1900

15

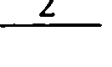

$\underline{\mathrm{H}_{2}}$
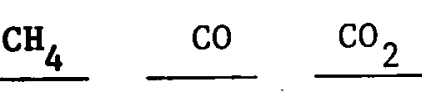

$\mathrm{O}_{2}$ $\underline{\mathrm{N}_{2}} \quad \underline{\mathrm{H}_{2} \mathrm{~S}} \cdot \underline{\mathrm{H}_{2} \mathrm{O}(1)}$

Coal, 1b/hr Stream.

2

1900

$200 \quad 11750$

0
6826

0

0

$3 \quad 1192$

1,55

13473

4689

$\begin{array}{lll}428 & 15116 \quad 4337\end{array}$

$\begin{array}{llll}408 & 12161 & 6339\end{array}$

1300

$1530 \quad 16631$

408

$2315 \quad 38035$

$59 \quad--$

660

1000

1100

235

150

1300 --

1300 . --

$1000 \quad 480$

$\begin{array}{ll}1192 & -- \\ 1192 & --\end{array}$

14120

647

13 
Table 6.3. EFFICIENCY SUMMARY FOR THE SYSTEM

IN FIGURE 6.2.

$\begin{array}{ll}\varepsilon_{F P} & 0.75 \\ \varepsilon_{F C} & 0.47 \\ \varepsilon_{P C} & 0.96 \\ { }^{\varepsilon_{S}} & 0.338 \\ { }_{\text {E } / H} & 0.496\end{array}$

Oxygen-Blown Coal Gasifier/Molten Carbonate Fuel Cell/Bottoming Cycle. ${ }^{7}$ Figure 6.3 shows a schematic flowsheet for an integrated system consisting of an oxygen-blown coal gasifier, a molten carbonate fuel cell, and a partially cascaded bottoming cycle. The mass balance is shown in Table 6.4. Table 6.5 contains the efficiency summary and indicates that $\varepsilon_{\mathrm{S} / \mathrm{H}}=0.503(6785 \mathrm{Btu} / \mathrm{kWh})$.

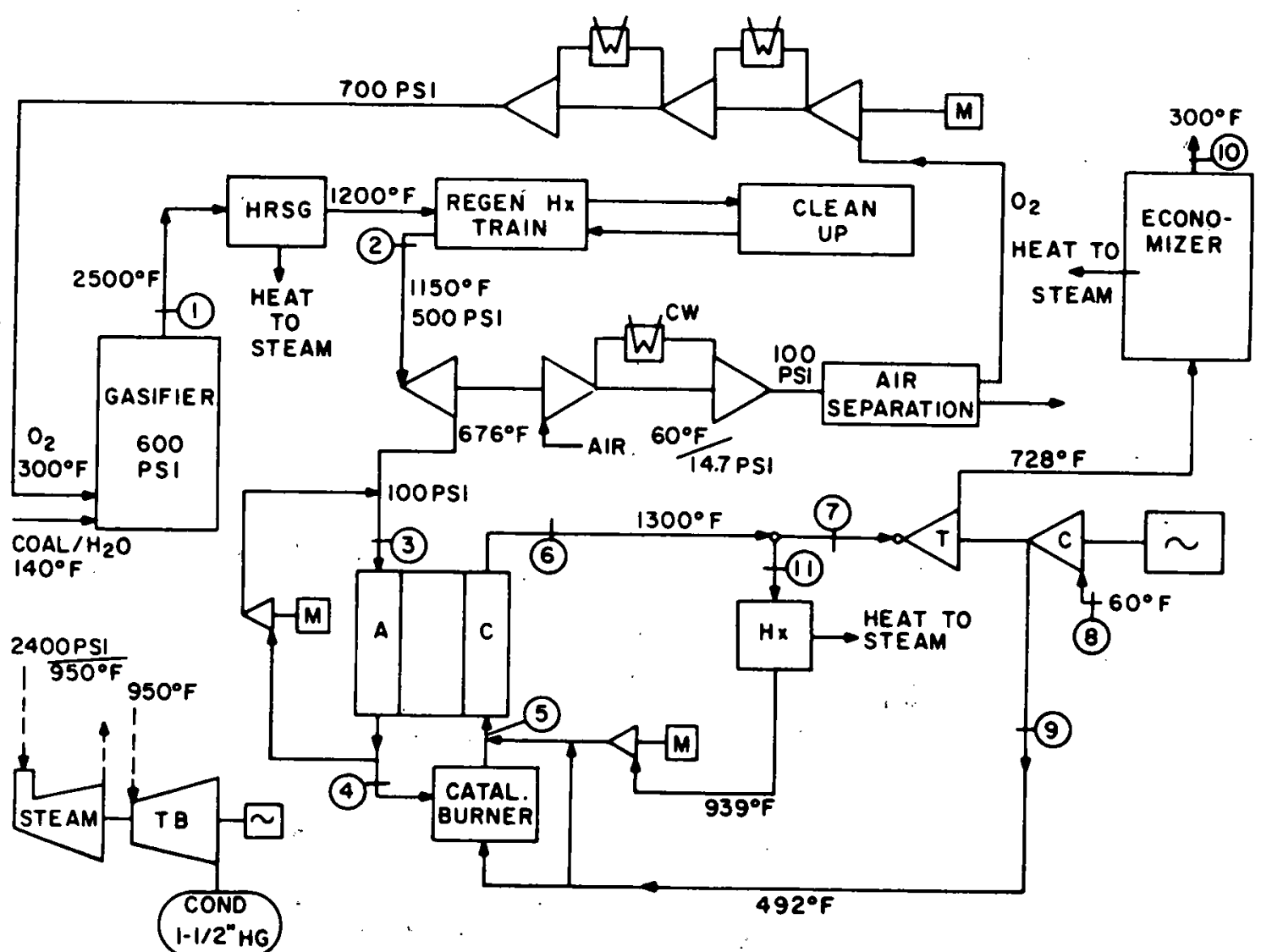

A80010205

Figure 6.3. OXYGEN-BLOWN COAL GASIFIER/MOLTEN CARBONATE FUEL CELL SYSTEM WITH PARTIALLY CASCADED STEAM BOTTOMING CYCLE ${ }^{7}$ 
Table 6.4. MASS BALANCE FOR THE SYSTEM IN FIGURE 6.3

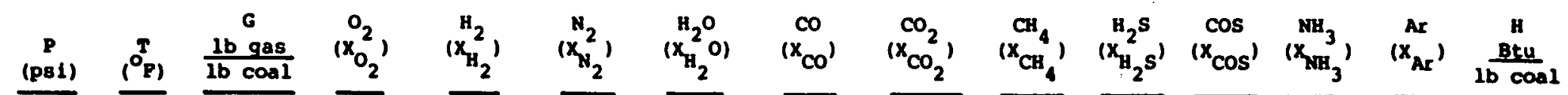


Table 6.5. EFFICIENCY SUMMARY FOR THE SYSTEM IN FIGURE 6.3

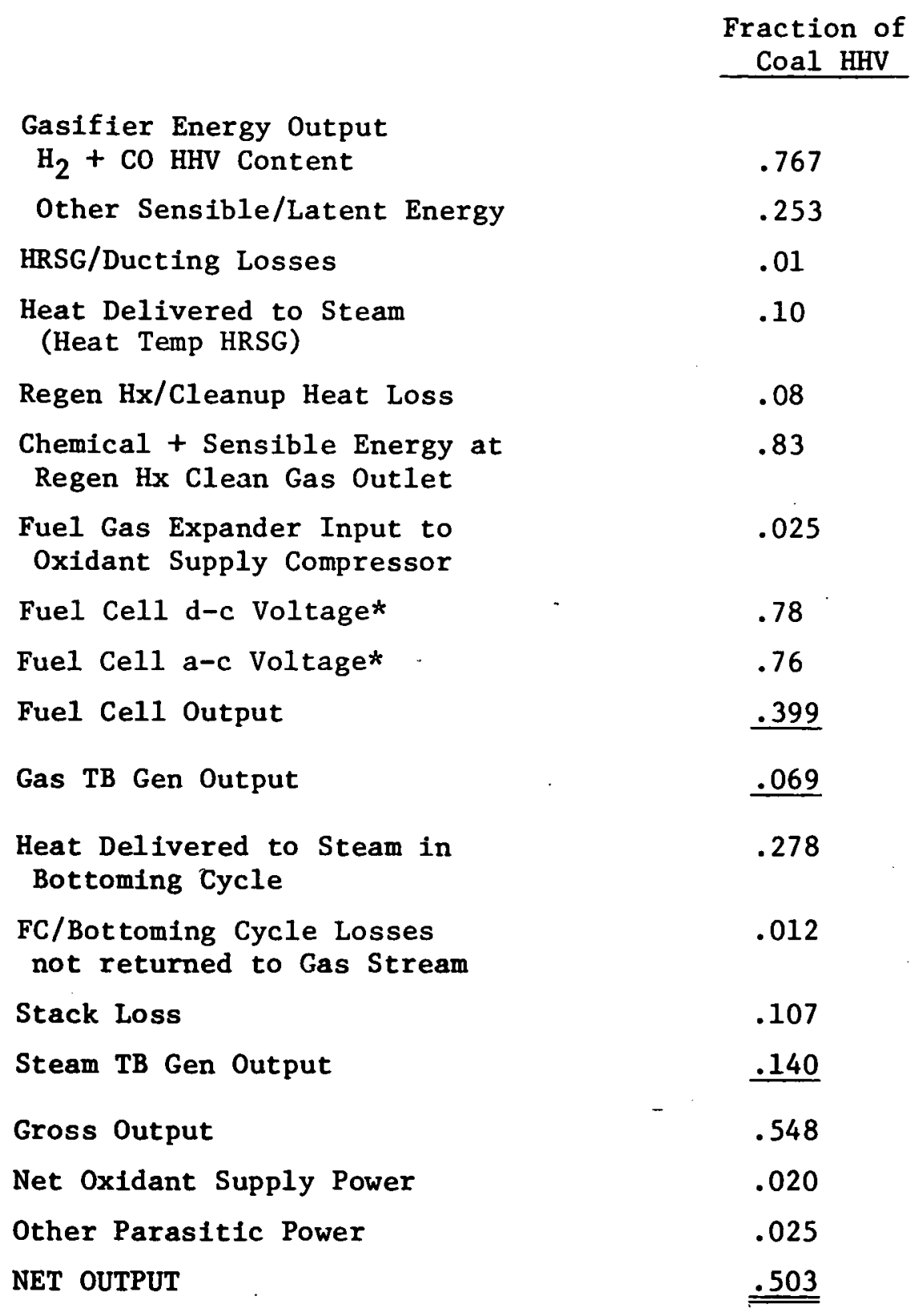

* Volts. 
Methanol Reformer/Phosphoric Acid Fuel Cell/Export Steam. ${ }^{12}$ Figure 6.4 . shows a phosphoric acid fuel cell operating on the product gas from a methanol reformer. The corresponding material balance is shown in Table 6.6. In addition to the electricity that is generated, 100 psig steam is available to use in a steam bottoming cycle or to provide process heat.

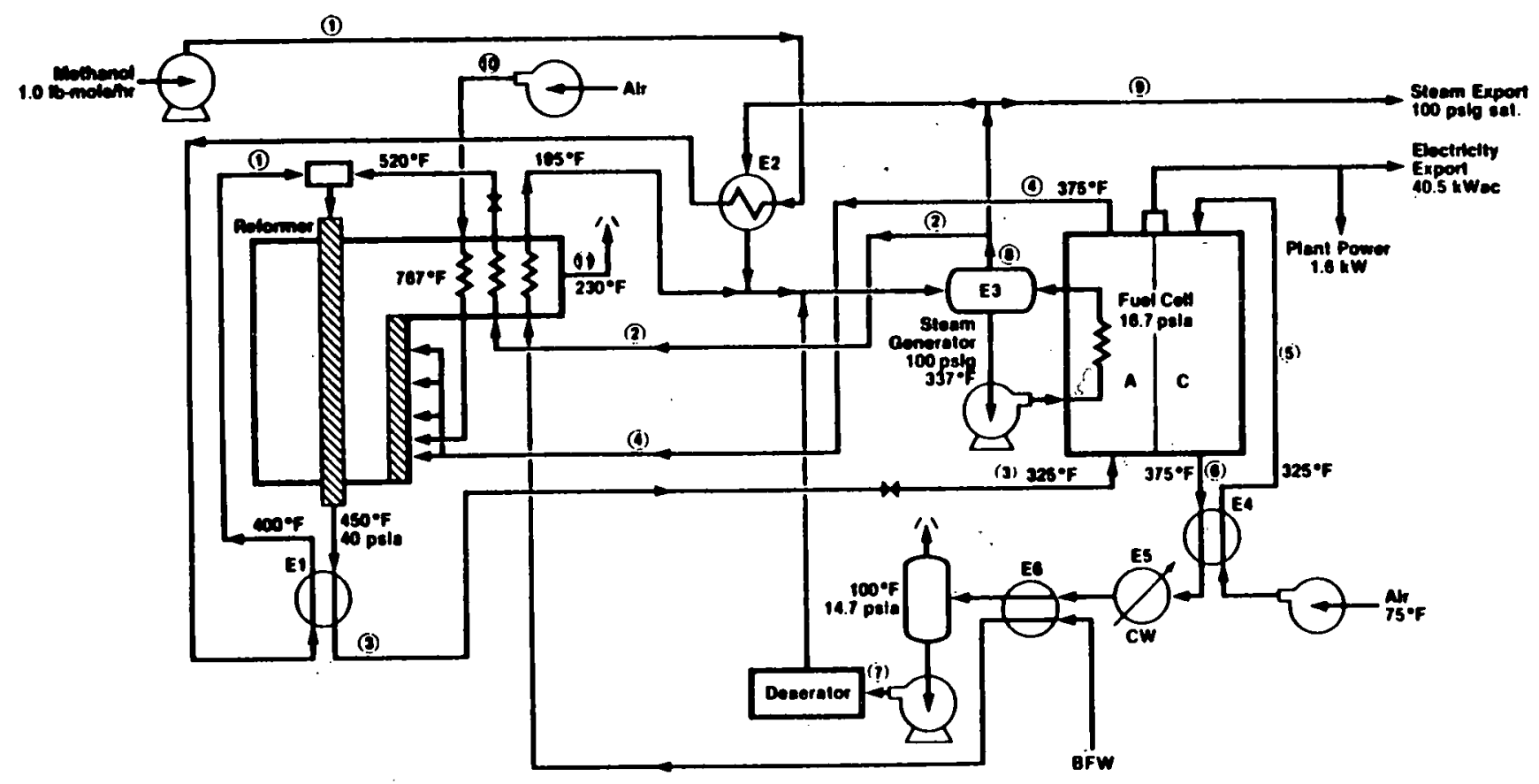

A80010206

F1gure 6.4. METHANOL REFORMER/PHOSPHORIC ACID FUEL CELL SYSTEM WITH EXPORT STEAM 12

The overall system efficiency, based on the higher heating value of 1iquid methanol and excluding the export steam, is $\varepsilon_{\mathrm{S}}=0.442(7718 \mathrm{Btu} / \mathrm{kWh})$. If the heat of vaporization is recovered from the export steam, $\varepsilon_{\mathrm{S} / \mathrm{H}}=0.752$ (4538 Btu/kWh). 
z

m

0.

$\pi$

- O

$>$

m
Table 6.6. MASS BALANCE FOR THE SYSTEM IN FIGURE 6.4

STREAM (lb-mol/hr)

\begin{tabular}{|c|c|c|c|c|c|c|c|c|c|c|}
\hline $\begin{array}{c}\text { Reformer } \\
\text { Feed } \\
1 \\
\end{array}$ & $\begin{array}{c}\text { Steam } \\
2 \\
\end{array}$ & $\begin{array}{c}\text { Anode } \\
\text { Feed } \\
3 \\
\end{array}$ & $\begin{array}{c}\text { Anode } \\
\text { Exit } \\
4 \\
\end{array}$ & $\begin{array}{l}\text { Cathode } \\
\text { Feed } \\
5 \\
\end{array}$ & $\begin{array}{c}\text { Cathode } \\
\text { Exit } \\
6 \\
\end{array}$ & $\begin{array}{c}\text { Condensate } \\
7 \\
\end{array}$ & $\begin{array}{c}\text { Steam } \\
8 \\
\end{array}$ & $\begin{array}{c}\text { Export } \\
\text { Steam } \\
9 \\
\end{array}$ & $\begin{array}{c}\text { Furnace } \\
\text { Air } \\
10 \\
\end{array}$ & $\begin{array}{c}\text { Flue } \\
\text { Gas } \\
11 \\
\end{array}$ \\
\hline & & 2.960 & 0.296 & & & & & & & \\
\hline & & 0.040 & 0.040 & & & & & & & \\
\hline & & 0.960 & 0.960 & & & & $\therefore$ & & & 1.000 \\
\hline & 1.600 & $0.640^{\circ}$ & 0.640 & & 2.664 & 1.880 & 8.000 & 6.059 & & 0.936 \\
\hline \multirow[t]{3}{*}{1.000} & & $<80 p p m$ & $<80 \mathrm{ppm}$ & & & & & 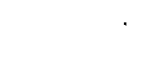 & & \\
\hline & & & & 2.664 & 1.332 & & & & 0.399 & 0.231 \\
\hline & & & & 10.022 & 10.022 & & & & i. 501 & 1.501 \\
\hline 1.000 & 1.600 & 4.600 & 1.936 & .12 .686 & 14.018 & 1.880 & 8.000 & 6.059 & 1.900 & 3.668 \\
\hline
\end{tabular}

$\begin{array}{lcccccc}\text { Exchangers } & \text { E1 } & \text { E2 } & \text { E3 } & \text { E4 } & \text { E5 } & \text { E6 } \\ \text { Btu/hr } & 4,600 & 15,100 & 129,600 & 21,920 & 39,400 & 9,000\end{array}$


No. 2 Fuel 0il Processing/Phosphoric Acid Fuel Cell/Export Steam. ${ }^{9}$ The sheet for a phosphoric acid fuel cell system operating on the product gas from a hybrid No. 2 fuel oil processor (high-temperature steam reforming followed by autothermal reforming) is shown in Figure 6.5. The heat and material balance is presented in Table 6.7. Excluding the exportable steam, $\varepsilon_{S}=0.38(8908 \mathrm{Btu} / \mathrm{kWh})$. Recovery of the export steam heat of vaporization and superheat results in $\varepsilon_{\mathrm{S} / \mathrm{H}}=0.546(6247 \mathrm{Btu} / \mathrm{kWh})$.

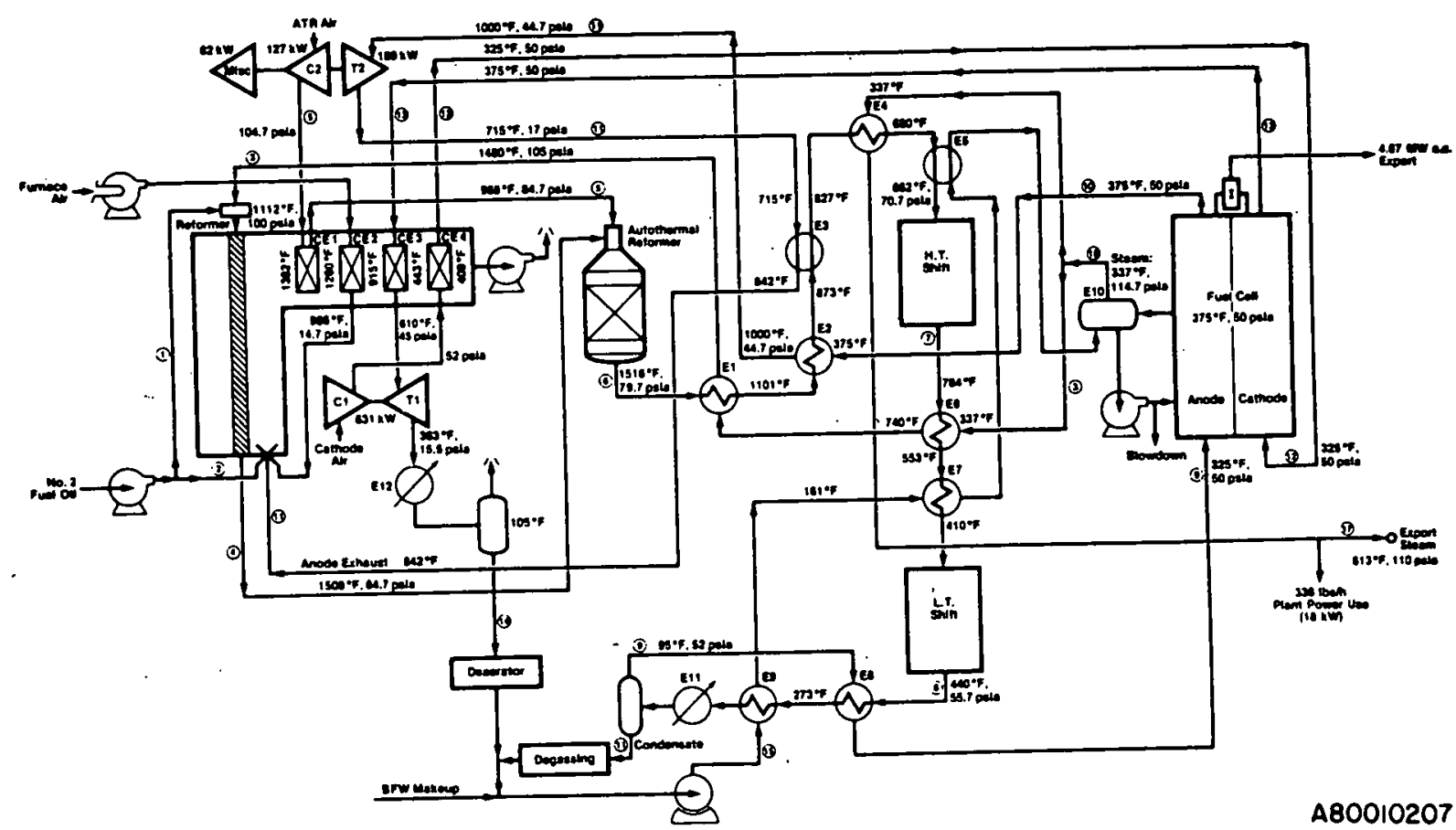

Figure 6.5. NO. 2 FUEL OIL PROCESSING/PHOSPHORIC ACID FUEL CELL/EXPORT STEAM $^{9}$

(Reprinted with permission from the Proceedings of the 14th Intersoclety Energy Engineering Conference. Copyright 1979 American Chemical Society.) 


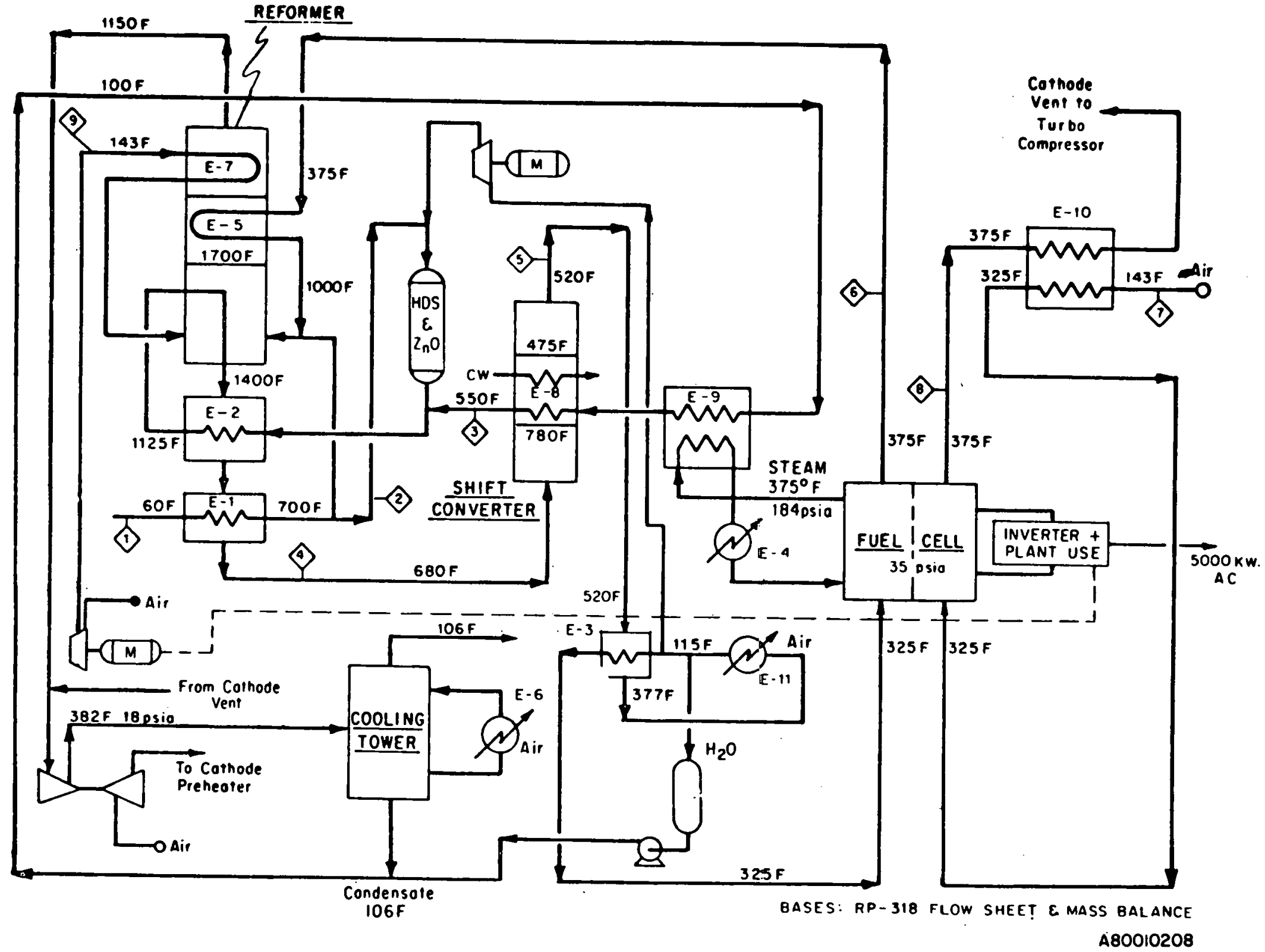

Figure 6.6. NAPHTHA STEAM REFORMER/PHOSPHORIC ACID FUEL CELL - FLOW SCHEMATIC ${ }^{8}$ 
Table 6.7. MASS AND ENERGY BALANCE FOR THE SYSTEM IN FIGURE 6.5

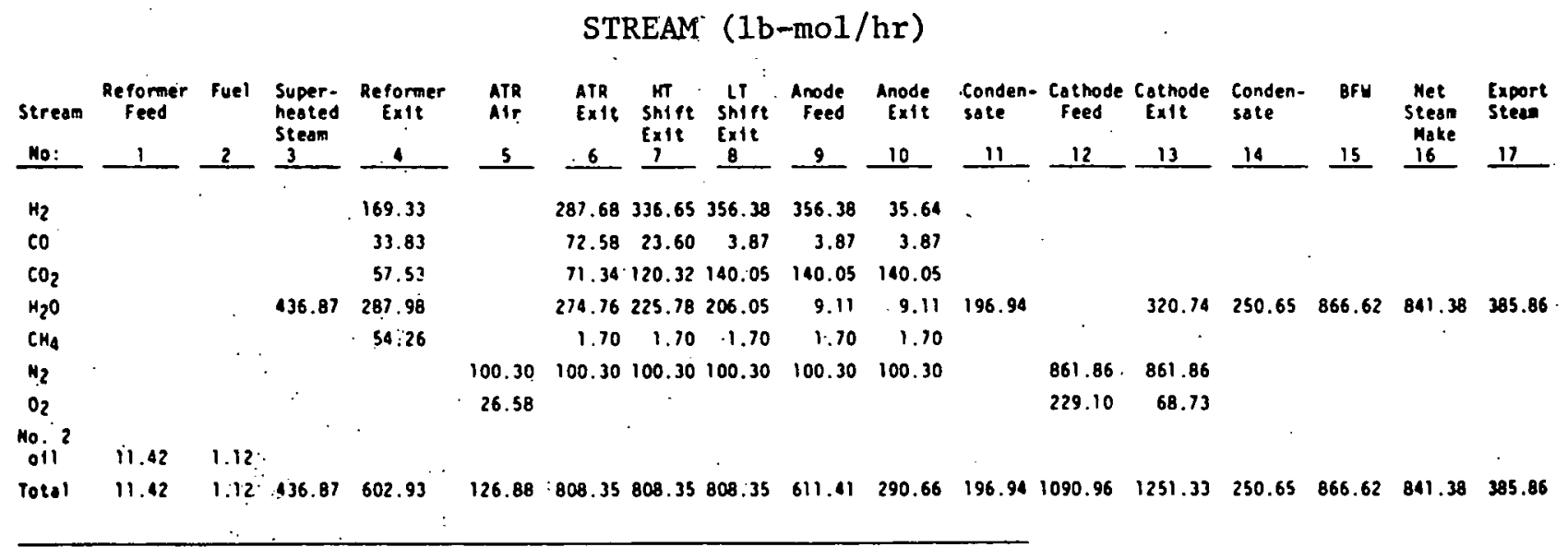

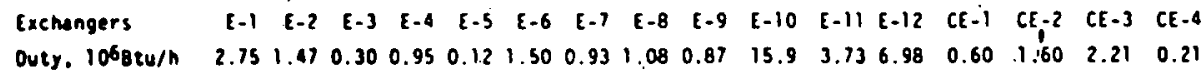

A80051341

Naphtha Reformer/Phosphoric Acid Fuel Cell. ${ }^{8}$ The integrated naphtha steam reformer/phosphoric acid fuel cell system shown in Figure 6.6 does not use a bottoming cycle or provide cogeneration heat. The mass and energy balance is shown in Table 6.8. For this system, $\varepsilon_{\mathrm{S}}=0.379(9000 \mathrm{Btu} / \mathrm{kWh})$. 
Table 6.8. MASS AND ENERGY BALANCE FOR SYSTEM IN FIGURE 6.6

-1

$-1$

$-1$

m

0

$\pi$

ケூ

z

○

ir

$\boldsymbol{0}$

$\prec$

STREAM $(1 b-m o l / h r)$

\begin{tabular}{|c|c|c|c|c|c|c|c|c|c|}
\hline Stream No. & 1 & 2 & 3 & 4 & 5 & 6 & 7 & $E$ & 9 \\
\hline \multicolumn{10}{|l|}{ Component } \\
\hline $\mathrm{H}_{2}$ & -- & -- & -- & $326: 2$ & 378.0 & 37.8 & -- & -- & -- \\
\hline $\mathrm{CO}$ & -- & -- & -- & 55.6 & 3.7 & 3.7 & -- & -- & -- \\
\hline $\mathrm{CO}_{2}$ & -- & -- & -- & 65.9 & 117.7 & 117.7 & -- & -- & -- \\
\hline $\mathrm{H}_{2} \mathrm{O}$ & -- & -- & 491.7 & 298.5 & 246.7 & 26.4 & -- & 347.3 & -- \\
\hline $\mathrm{CH}_{4}$ & -- & -- & -- & 1.4 & 1.4 & 1.4 & -- & -- & -- \\
\hline $\mathrm{O}_{2}$ & -- & -- & -- & -- & -- & -- & 378.1 & 207.9 & 89.8 \\
\hline$i_{2}$ & - & -- & -- & -- & -- & -- & 1422.3 & 1422.3 & 337.0 \\
\hline TOTAL & -1 & -- & 491.7 & 747.6 & 747.6 & 187.1 & 1800.3 & 1970.5 & $\therefore 26.8$ \\
\hline $\mathrm{lb} / \mathrm{hr}$ & 2,250 & 1,756 & 8,851 & 10,608 & 10,608 & 5,858 & 29,082 & 20,763 & 12.334 \\
\hline
\end{tabular}

$\begin{array}{lrrrrrrrrrrrrr}\text { Exchangers } & E-1 & E-2 & E-3 & E-4 & E-5 & E-6 & E-7 & E-9 & E-10 & E-11 & E-12 & E-13 \\ \text { Duty, AMBtulin } & 1.09 & 3.47 & 0.85 & 5.48 & 1.21 & 8.22 & 2.24 & 9.30 & 2.28 & 4.18 & 0.94 & 0.66\end{array}$




\section{REFERENCES CITED}

1. Fickett, A. P., "Fuel Cells: Versatile Power Generators," EPRI J., 14-19 (1976) March.

2. Fickett, A. P., "Fuel Cell Power Plants," Sci. Amer., 70-76 (1978)

November.

3. Catalytica Associates, Inc., "Assessment of Fuel Processing Alternatives for Fuel Cell Power Generation," EPRI Report EM-570. Palo Alto, Ca., 1977.

4. Bolan, P., "Heat Pumps and Fuel Cells." Paper presented at 69th Annual Meeting of American Institute of Chemical Engineers, ChIcago, November 27December 4, 1976.

5. United Technologies Corporation, "Integrated Coal Gasifier/Molten Carbonate Fuel Cell Power Plant Conceptual Design and Implementation Assessment," NASA Report CR 134955, Contract NAS 3-19586. South Windsor, Conn., 1977.

6. Bolan, P. and Hall, E. W., "Industrial Applications of On-Site Fuel Cell Power Plants." Paper presented at the National Fuel Cell Seminar, Boston, June 21, 1977.

7. General Electric Company, "Fuel Cell Power Plant Integrated Systems Evaluation," EPRI Report EM-1097. Schenectady, N.Y., 1979.

8. Arthur D. Little, Inc., "Assessment of Fuels for Power Generation by Electric Utility Fuel Cells," EPRI Report EM-695. Cambridge, Mass., 1978.

9. Ushıba, K. K., Mahawili, I., and Tio, T. H., "A 5-MW Acid Fuel Cell Power Plant Featuring High Temperature Steam Reforming of No. 2 Fuel 011 Combined with Autothermal Reforming." Paper presented at 14th Intersociety Energy Conversion Engineering Conference, Boston, August 5-12, 1979.

10. Simons, S. N. and Maag, W. L., "Analysis of a Fuel Cell On-Site Integrated Energy System for a Residential Complex," NASA Technical Memorandum 79161. Paper presented at the Terrestrial Energy Systems Conference, Orlando, Fla., June 4-6, 1979.

11. Institute of Gas Technology, "Fuel Cell Support Studies - On-Site Molten Carbonate Studies," Final Report under Gas Research Institute Contract No. 5011-344-0092. Chicago, 1979.

12. Catalytica Associates, Inc., "Overview of Fuel Processing Technologies for Fuel Cell Power Generation," Final Report under U.S. Department of Energy Contract No. EC-77-C-03-1384. Palo Alto, Ca., 1978. 
APPENDIX A. HEATING VALUES OF POTENTIAL FUEL CELL SYSTEM FUELS
I N S T I T U T E
O F
G A S
T E C H N O L O 
Appendix A contains heating values for hydrocarbon fuels that can be fed to an appropriate fuel processor to supply hydrogen to a fuel cell. Some comments on thermodynamic nomenclature are also included.

For any reaction,

$\Delta G=\Delta H-T \Delta S$

where $\Delta \mathrm{H}$ is the enthalphy change associated with the reaction. For a combustion reaction, $\Delta H$ is called the heat of combustion or heating value. For complete combustion of compounds containing carbon and hydrogen, the products are carbon dioxide and water. When the state of the product water is liquid, that is, when the water is condensed (Equation A.2), the heating value is the higher or gross heating value.

$$
\mathrm{H}_{2}+1 / 2 \mathrm{O}_{2}+\mathrm{H}_{2} \mathrm{O}(1)
$$

If the water is not condensed (Equation A.3), the lower or net heating value is obtained.

$$
\mathrm{H}_{2}+1 / 2 \mathrm{O}_{2} \rightarrow \mathrm{H}_{2} \mathrm{O}(\mathrm{g})
$$

The difference between the higher and lower heating values is the heat of condensation of the product water.

Thus, Equation A.1 describes both Equation A.2 and A.3 with the appropriate (higher or lower) heating value. It should be clear, though, that $\Delta G$ is not the lower heating value; rather, $\Delta G$ is simply related to $\Delta H$ by Equation A.1.

The development of the equations describing fuel cell efficiency found in Chapter 5 was based on lower heating values, because the operating temperatures of both phosphoric acid and molten carbonate fuel cells prevent the condensation of water within the cell. On the other hand, in Chapter 6, the development of the equations describing fuel cell efficiency was based on the higher heating value of the raw fuel (coal, oil, etc.) fed to the fuel processor, because the product water can be condensed in a heat recovery scheme. 
Table A-1. FUEL OIL HIGHER HEATING VALUES ${ }^{1}$

\begin{tabular}{|c|c|c|}
\hline Fue1 & $1 \mathrm{~b} / \mathrm{ga} 1$ & Btu/gal \\
\hline$\# 1$ & $6.879-7.085$ & $135800-138800$ \\
\hline$\# 2$ & $7.128-7.490$ & $139400-144300$ \\
\hline$\# 4$ & $7.538-7.587$ & $145000-145600$ \\
\hline$\# 5$ & $7.686-7.891$ & $146800-149400$ \\
\hline$\# 6$ & $7.998-8.108$ & $150700-152000$ \\
\hline
\end{tabular}

Table A-2. HIGHER HEATING VALUE OF BENZENE AND ALCOHOLS ${ }^{1}$

\begin{tabular}{clr} 
Fuel & & Btu/1b \\
\cline { 3 - 3 } Methanol & $\mathrm{CH}_{3} \mathrm{OH}$ & 9550 \\
Ethanol & $\mathrm{C}_{2} \mathrm{H}_{5} \mathrm{OH}$ & 12780 \\
Benzene & $\mathrm{C}_{6} \mathrm{H}_{6}$ & 18000
\end{tabular}

Table A-3. COMPOSITION AND HIGHER HEATING VALUE OF NATURAL GAS ${ }^{1}$

\begin{tabular}{|c|c|c|c|c|c|c|}
\hline Gas & $\underline{\mathrm{CO} 2}$ & $\mathrm{~N}_{2}$ & $\mathrm{CH}_{4}$ & $\mathrm{C}_{2} \mathrm{H}_{6}$ & Btu/ft ${ }^{3}$ & $\underline{S G *}$ \\
\hline Texarkana & 0.80 & 3.2 & 96 & 0 & 967 & .57 \\
\hline Clèveland & 0 & 1.3 & 80.5 & 18.2 & 1131 & .65 \\
\hline $\begin{array}{l}\text { O11 City, Pa. } \\
* \text { a1r }=1.0\end{array}$ & 0 & 1.1 & 67.6 & 31.3 & 1232 & .71 \\
\hline
\end{tabular}


Table A-4. HIGHER HEATING VALUE OF COAL ${ }^{1}$

Heating

Value

Rank

Anthracitic:

Meta-anthracite

Anthracite

Anthracite

Semianthracite

Bituminous :

Low-volatile

Medium-volatile

High-volatile A

High-volatile A

High-volatile B

High-volatile B

High-volatile C

High-volatile C

Subbituminous:

Subbituminous A or highvolatile bituminous $C$

Subbituminous $B$

Subbituminous $\mathrm{C}$

Lignite:

Lignite

State

Rhode Island

Pennsylvania

Pennsylvania

Virginia

West Virginia Pocahontas No. 3

West Virginia Sewell

Pennsylvania

Kentucky

Ohio

Kentucky

Illinois

Indiana

Wyoming

Wyoming

Wyoming

North Dakota
$-$

Uncorrelated

Mammoth

Big Lykens

Merrimac

Pittsburgh

Elkhorn

Middle Kittanning

No. 6

No. 2

No. 6

Btu/lb
9,620

13,540

13,480

12,270

14,550

14,290

13,610

14,290

12,160

12,950

11,480

11,420

9,740

9,420

8,610

7,210

A80051343 
Table A-5. IDEAL GAS HEATING VALUES ${ }^{2}$

\begin{tabular}{cc} 
Ideal Gas & $\begin{array}{c}\text { Ideal Gas Gross } \\
\text { Calorific Value** } \\
\text { Specific Gravity* }\end{array}$ \\
\hline
\end{tabular}

0.5539

1.0382

1.5224

2.0067

2.0067

2.0067

2.4910

2.4910

2.4910

2.9753

0.9686

1.4528

1.9371

1.9371

1.9371

1.9371

1.9371

2.4214

2.4214

2.4214

2.4214

2.4214

2.4214

2.4214

0.8990

1.8675

2.2822

2.6969

3.1812

3.6654

1012.0
1772.9
2523.0
3260.1
3269.6
3265
4009.4
4018.5
4014
4758
1602.9
2339.0
3087.3
3079.7
3073.4
3068.0
3077
3835.3
3828.2
3823.4
3819.2
3827.5
3812.3
3824
1476.2
2887.7
3362.0
3750.6
4485.2
5224

1.0000

1.5194

0.9671

0.1382

0.0696

1.1765

0.9672

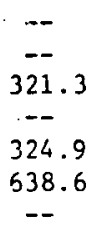

--
Ideal Gas Net

Calorific Value, $* \star$ $\mathrm{Btu} / \mathrm{ft}^{3}$

\author{
911.2 \\ 1621.6 \\ 2321.4 \\ 3008.0 \\ 3017.5 \\ 3013 \\ 3706.4 \\ 3716.0 \\ 3711 \\ 4405 \\ 1502.0 \\ 2187.8 \\ 2885.6 \\ 2878.0 \\ 2871.7 \\ 2866.3 \\ 2875 \\ 3583.1 \\ 3576.1 \\ 3571.3 \\ 3567.1 \\ 3575.3 \\ 3560.2 \\ 3572 \\ 1425.7 \\ 2736.4 \\ 3210.0 \\ 3599.3 \\ 4283.5
}

4972

--
$\overline{--}$
321.3
--
274.5
588.2
--

$--$
Compressibilit: Summation Factor

0.0436

0.0917

0.1342

0.1744

$0.182=$

0.178

0.2276

0.2377

0.233

0.283

0.0775

0.1269

0.1749

0.1863

0.1860

0.1769

0.181

0.230

0.230

0.230

0.230

0.230

0.230

0.230

0.0833

0.158

0.224

0.266

0.311

0.36

Hydrogen sulfide

Nitrogen

0.0202

0.0640

0.0217

$-0.017$

0.0985

0.0164

* Ratio of molecular weight (1971) of component to that of air (28.9644).

${ }^{\star \star}$ Combustion at $60^{\circ} \mathrm{F}\left(15.6^{\circ} \mathrm{C}\right)$; volume of a pound mole of ideal gas at $14.73 \mathrm{psia}(101 \mathrm{kPa})=378.601 \mathrm{ft}^{3}$ $\left(10.798 \mathrm{~m}^{3}\right)$ on the dry basis. Source of data is the "Selected Values of Propertles of Hydrocarbons and Related Compounds" from the American Petroleum Institute Research Project 44 . Additional details are available from ASTM Research Report No. D03-1000. 
Table A-6. THERMODYNAMIC VALUES FOR $\mathrm{H}_{2}+1 / 2 \mathrm{O}_{2} \rightarrow \mathrm{H}_{2} \mathrm{O}(\mathrm{g})^{3}$

\begin{tabular}{|c|c|c|c|}
\hline Temperature, ${ }^{\circ} \mathrm{K}$ & $\Delta G^{\circ}, \mathrm{cal} / \mathrm{g}$-mol & $\Delta \mathrm{H}^{\circ}, \mathrm{ca} 1 / \mathrm{g}-\mathrm{mol}$ & $\mathrm{E}^{\circ}, \mathrm{V}$ \\
\hline 298 & 54583 & 57973 & 1.184 \\
\hline 600 & 51147 & 58342 & 1.109 \\
\hline 800 & 48610 & 58757 & 1.054 \\
\hline 1000 & 46005 & 59034 & 0.997 \\
\hline 1250 & 42615 & 59633 & 0.924 \\
\hline 1500 & 39202 & 59702 & 0.850 \\
\hline
\end{tabular}




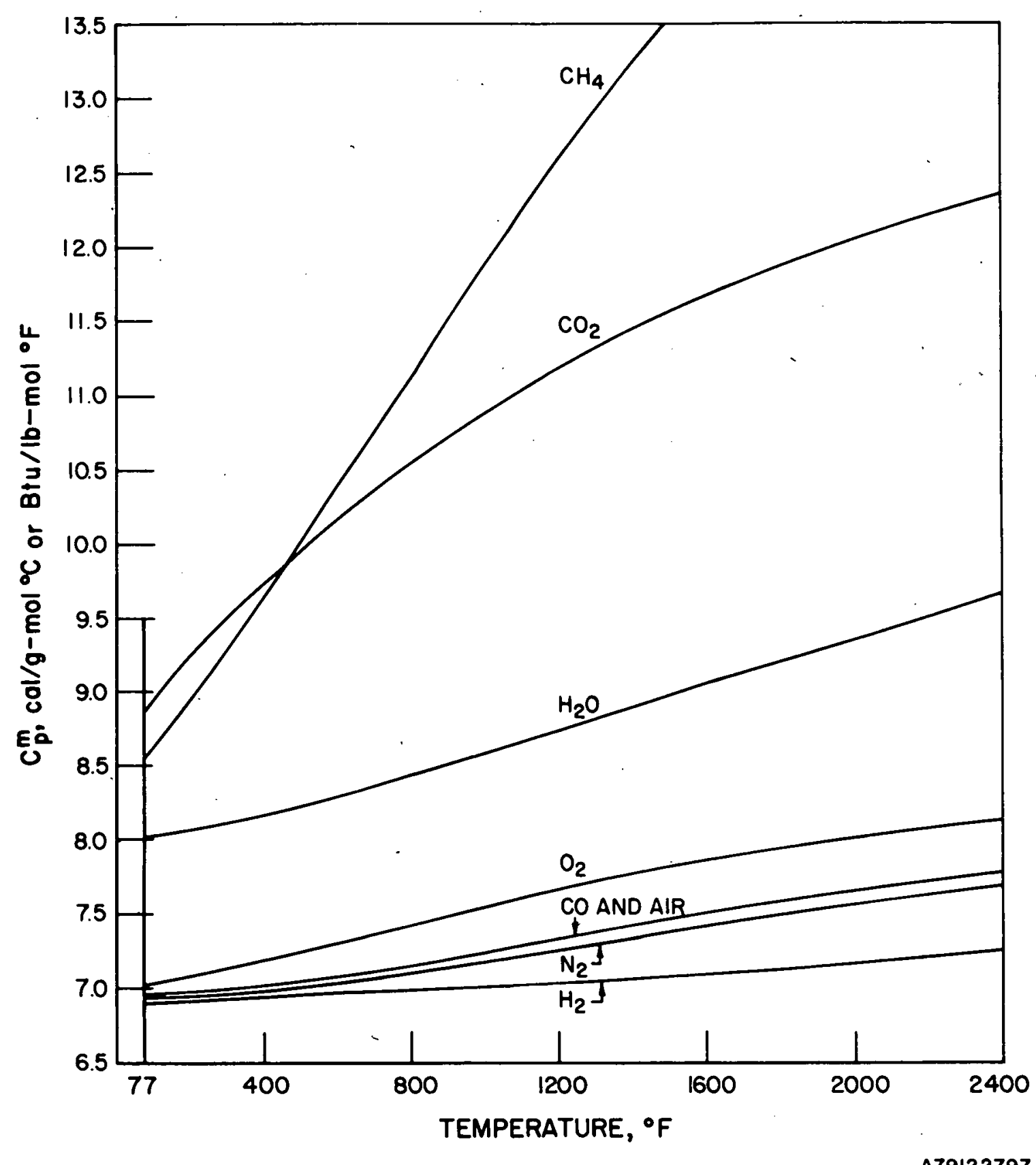

A79122797

Figure A-1. MEAN HEAT CAPACITIES OF GASES IN THE IDEAL-GAS STATE (Base Temperature, $\left.77^{\circ} \mathrm{F}\right)^{4}$. 


\section{REFERENCES CITED}

1. Perry. R. H., Chilton, C. H., and Kirkpatick, S. D., Eds., Perry's Chemical Engineers' Handbook, 4th Ed., New York: McGraw-Hil1, 1963.

2. American Society for Testing and Materials, "Standard Method of Calculating Calorific Value and Specific Gravity of Gaseous Fuels," ASTM D 3588-79, Part 26, Philadelphia, 1979.

3. Broers, G. H. J., "High Temperature Galvanic Fuel Cells," Ph.D. Thesis, University of Amsterdam, 1958.

4. Smith, J. M. and Van Ness, H. C., Introduction to Chemical Engineering Thermodynamics. New York: McGraw-Hill, 1959. 
APPENDIX B. CONVERSION FACTORS AND FUEL CELL̈ CONSTANTS 
Table B-1. VALUE OF UNIVERSAL GAS CONSTANT R IN VARIOUS UNITS

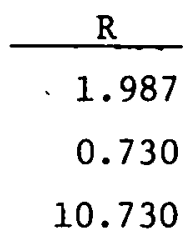

1545.000

1.314

82.060

\section{Units}

Btu/1b-mol ${ }^{\circ} \mathrm{R}$ or $\mathrm{cal} / \mathrm{g}-\mathrm{mol}{ }^{\circ} \mathrm{K}$

atm-- $\mathrm{ft}^{3} / 1 \mathrm{~b}-\mathrm{mol}{ }^{\circ} \mathrm{R}$

psia-ft $t^{3} / 1 b-m o 1{ }^{\circ} R$

$\left(1 b / f t^{2}\right)\left(f t^{3}\right) / 1 b-m o 1{ }^{\circ} R$ or $f t-1 b / 1 b-m o 1{ }^{\circ} R$ atm- $f t^{3} / 1 b-m o l{ }^{\circ} \dot{K}$

atm- $\mathrm{cm}^{3} / \mathrm{g}-\mathrm{mol}{ }^{\circ} \mathrm{K}$

Table B-2. VALUE OF FARADAY'S CONSTANT F IN VARIOUS UNITS

$\frac{F}{96490}$
23.06

$\frac{\text { Units }}{\mathrm{c} / \mathrm{g} \text {-equivalent }}$
$\mathrm{kcal} / \mathrm{volt}-\mathrm{g}$-equivalent

Table B-3. MISCELLANEOUS CONVERSION FACTORS

Multiply
Btu
$\mathrm{cal} / \mathrm{g}-\mathrm{mol}{ }^{\circ} \mathrm{C}$
$\mathrm{C}$
$\mathrm{mA} / \mathrm{cm}^{2}$
watt

\begin{tabular}{l} 
by \\
\hline 252 \\
1.0 \\
1.0 \\
0.929 \\
1.0
\end{tabular}

to get

cal

Btu/1b-mol ${ }^{\circ} \mathrm{F}$

$\mathrm{A}-\mathrm{sec}$

$\mathrm{A} / \mathrm{ft} \mathrm{t}^{2}$

$\mathrm{V}-\mathrm{A}$ 
Table B-4. ENERGY UNIT CONVERSION CHART

\begin{tabular}{|c|c|c|c|c|c|}
\hline \multirow{2}{*}{$\begin{array}{c}\text { BRITISH THERMAL } \\
\text { UNITS } \\
\text { (BiU) }\end{array}$} & \multicolumn{2}{|c|}{ NATURAL GAS ** } & \multirow{2}{*}{$\begin{array}{c}\text { RILOWATT MOURS } \\
\text { ELECTRICITY } \\
\text { (klhr) }\end{array}$} & \multirow{2}{*}{$\begin{array}{c}\text { BARRELS } \\
\text { OlL } \\
\text { (bbl) } \\
\end{array}$} & \multirow{2}{*}{$\begin{array}{l}\text { SHORT TONS } \\
\text { BITUMINOUS COAL } \\
\text { (T) }\end{array}$} \\
\hline & CF & Therms & & & \\
\hline 3 & - & - & 0.000293 & - & - \\
\hline 1000 & 1 & 0.01 & 0.293 & 0.00017 & 0.00004 \\
\hline 3413 & 3.413 & 0.03413 & 3 & 0.00059 & 0.00014 \\
\hline 100,000 & 100 & 1 & 29.3 & 0.017 & 0.004 \\
\hline 1418104 & $1000110 \mathrm{H}$ & 10 & 293 & 0.17 & 0.04 \\
\hline 3.41 MILLION & 3413 & 34.1 & $100011 \% 01$ & 0.59 & 0.14 \\
\hline 5.8 MILLION & 5800 & 58 & 1700 & 1 & 0.23 \\
\hline 25 MILLION & 25,000 & 250 & 7325 & 4.31 & 3 \\
\hline 1 BILLION & 111,65 & 10,000 & 293,000 & 172 & 40 \\
\hline 3.41 BILLION & 3.41 MILLION & 34,100 & +10\% & 588 & 136 \\
\hline I TRILLION & (6) & 10 MILLLION & 293 MILLION & 172,000 & 40,000 \\
\hline 5.8 TRILLION & 5.8 BILLION & 58 MILLION & 1.7 BILLION & 1THWT & 232,000 \\
\hline 25 TRILLION & 25 BILLION & 250 MILLION & 7.32 BILLION & 4.31 MILLION & $1+1140$ o \\
\hline 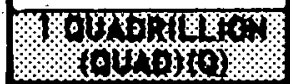 & Hrof & 10 BILLION & 293 BILLION & 172 MILLION & 40. MILLION \\
\hline
\end{tabular}

\footnotetext{
- Bosed on the following nominal fuel heoting values: "* Substifute Natural Gas (SNG) and

1 Cubic Foot Natural Gos $=1000$ Biu

1 Borrel Crude Oil $\quad=5.8$ Million Biv

1 Pound Bituminous Cool $=12,500$ Btu

Liquelied Natural Gos (LNG)

$M=1000$

$M M=1,000,000$

will have opproximotely the some

heating value.
} 
APPENDIX C. LIST OF SYMBOLS 


\section{LIST OF SYMBOLS}

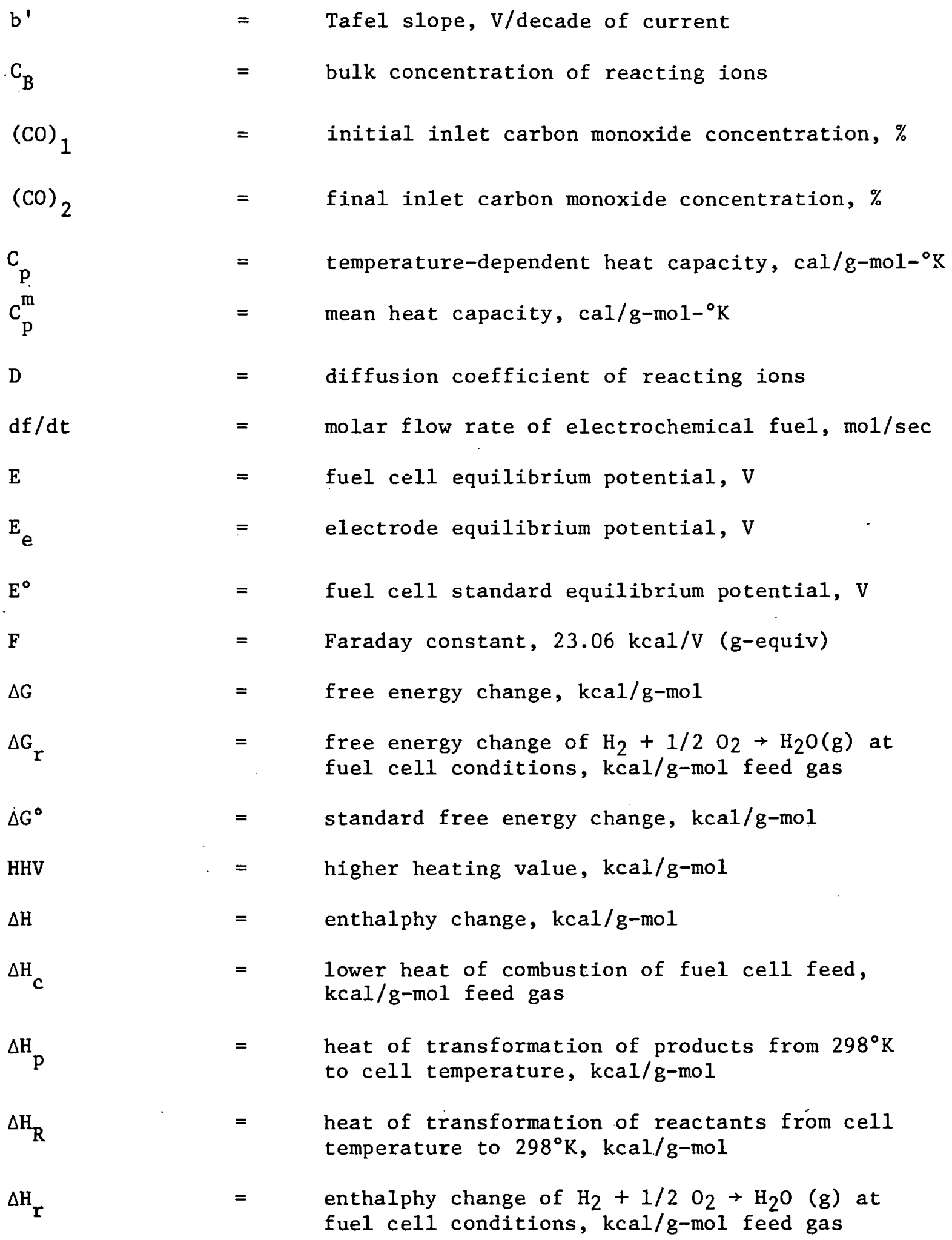




\begin{tabular}{|c|c|c|}
\hline$\Delta \mathrm{H}_{298}$ & $\dot{=}$ & $\begin{array}{l}\text { enthalphy change of } \mathrm{H}_{2}+1 / 2 \mathrm{O}_{2} \rightarrow \mathrm{H}_{2} \mathrm{O}(\mathrm{g}) \text { at } 298^{\circ} \mathrm{K} \text {, } \\
\mathrm{kcal} / \mathrm{g}-\mathrm{mol}\end{array}$ \\
\hline I & $=$ & actual fuel cell current, $A$ \\
\hline$I_{F}$ & $\dot{=}$ & current predicted by Faraday's law, A \\
\hline$i$ & $=$ & current density, $\mathrm{mA} / \mathrm{cm}^{2}$ \\
\hline$i_{L}$ & $=$ & limiting current density, $\mathrm{mA} / \mathrm{cm}^{2}$ \\
\hline$i_{0}$ & $=$ & exchange current density, $\mathrm{mA} / \mathrm{cm}^{2}$ \\
\hline $\mathrm{K}$ & $=$ & equilbrium constant \\
\hline $\mathrm{K}_{\mathrm{p}}$ & $=$ & water-gas shift reaction equilibrium constant \\
\hline $\mathrm{LHV}_{\mathrm{i}}$ & $=$ & - lower heating value of species $i, \mathrm{kcal} / \mathrm{g}-\mathrm{mol}$ \\
\hline $\mathrm{m}$ & $=$ & stoichiometric coefficient \\
\hline $\mathrm{n}$ & $=$ & $\begin{array}{l}\text { number of electrons transferred in a reaction, } \\
\text { g-equiv/g-mol }\end{array}$ \\
\hline $\mathrm{P}_{1}$ & $=$ & initial cell pressure, atm \\
\hline $\mathrm{P}_{2}$ & $=$ & final cell pressure, atm \\
\hline$\left(\mathrm{P}_{\mathrm{CO}_{2}}\right)_{\mathrm{a}}$ & $=$ & anode inlet $\mathrm{CO}_{2}$ partial pressure \\
\hline$\left.{ }^{(\mathrm{P}} \mathrm{CO}_{2}\right)_{\mathrm{c}}$ & $=\cdots$ & cathode inlet $\mathrm{CO}_{2}$ partial pressure \\
\hline$\left(\overline{\mathrm{P}}_{\mathrm{CO}_{2}} \cdot \overline{\mathrm{P}}_{\mathrm{O}_{2}}^{1 / 2}\right)_{1}$ & $=$ & initial average oxidant partial pressure, atm $3 / 2$ \\
\hline$\left(\overline{\mathrm{P}}_{\mathrm{CO}_{2}} \overline{\mathrm{P}}_{\mathrm{O}_{2}}^{1 / 2}\right)_{2}$ & $=$ & final average oxidant partial pressure, atm $3 / 2$ \\
\hline $\mathrm{P}_{\mathrm{H}_{0}}$ & $=$ & hydrogen partial pressure, atm \\
\hline$\left(\overline{\mathrm{P}}_{\mathrm{H}_{2}}\right)_{1}$ & $=$ & initial average hydrogen partial pressure, atm \\
\hline$\left(\overline{\mathrm{P}}_{\mathrm{H}_{2}}\right)$ & $=$ & final average hydrogen partial pressure, atm \\
\hline
\end{tabular}




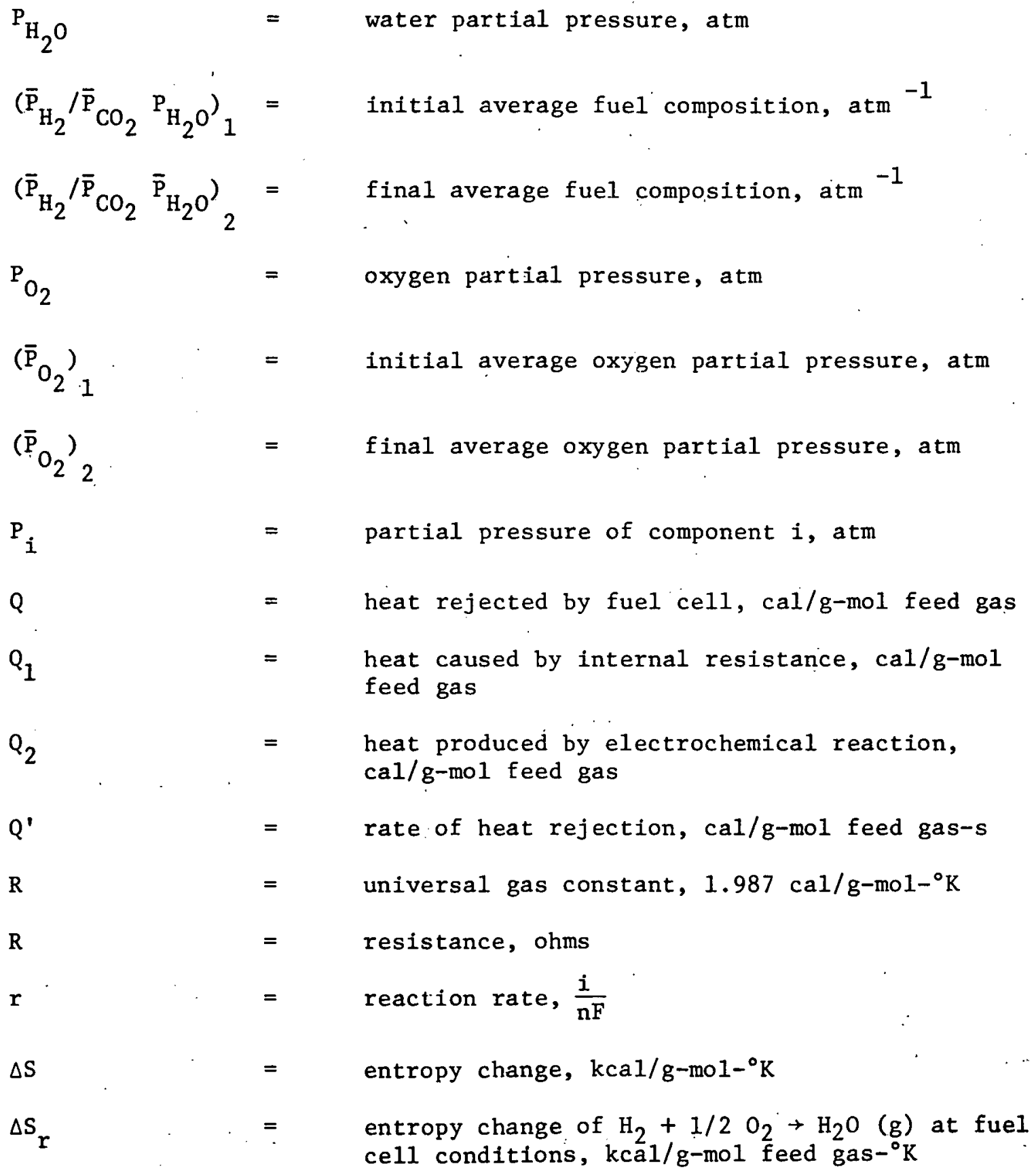




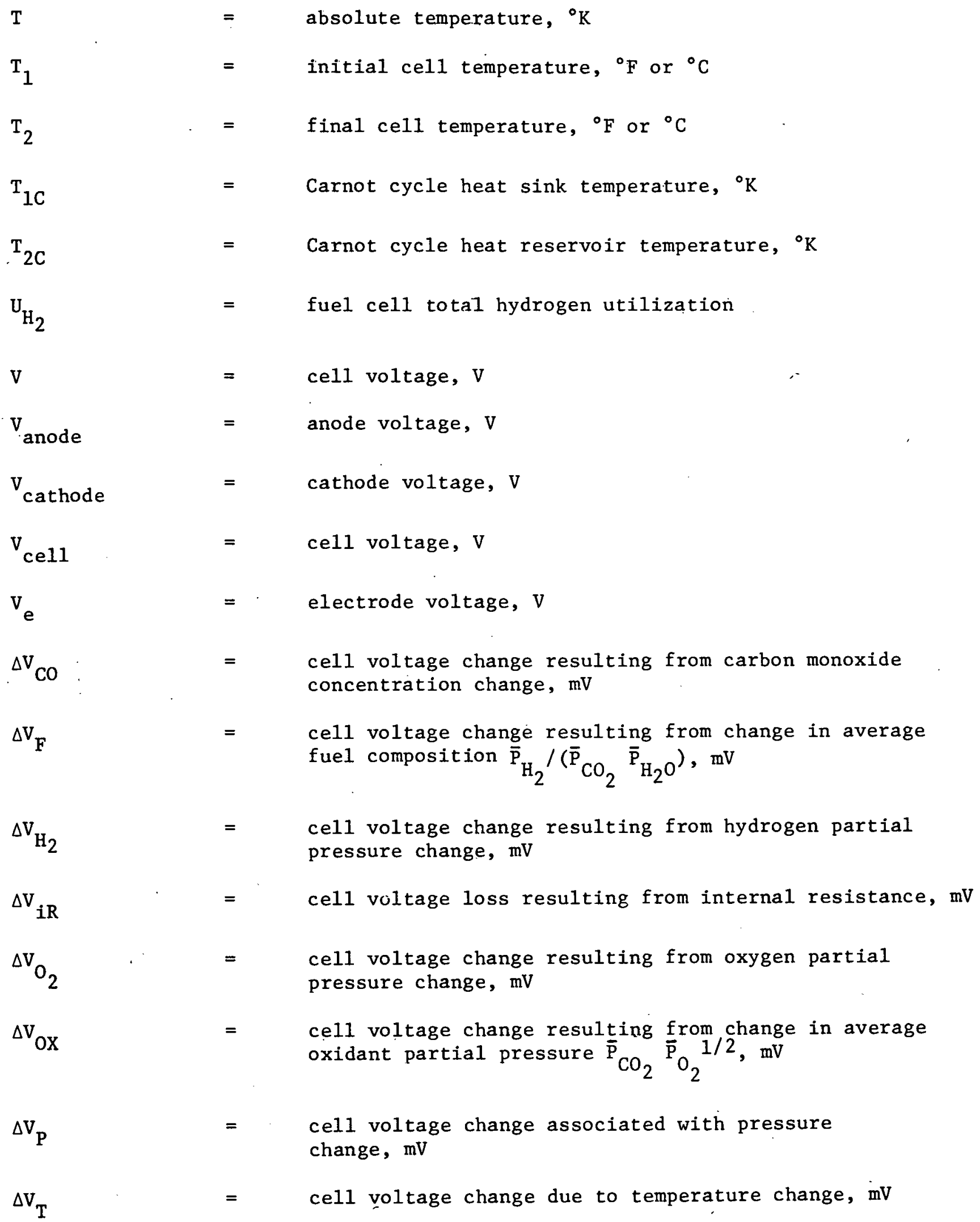




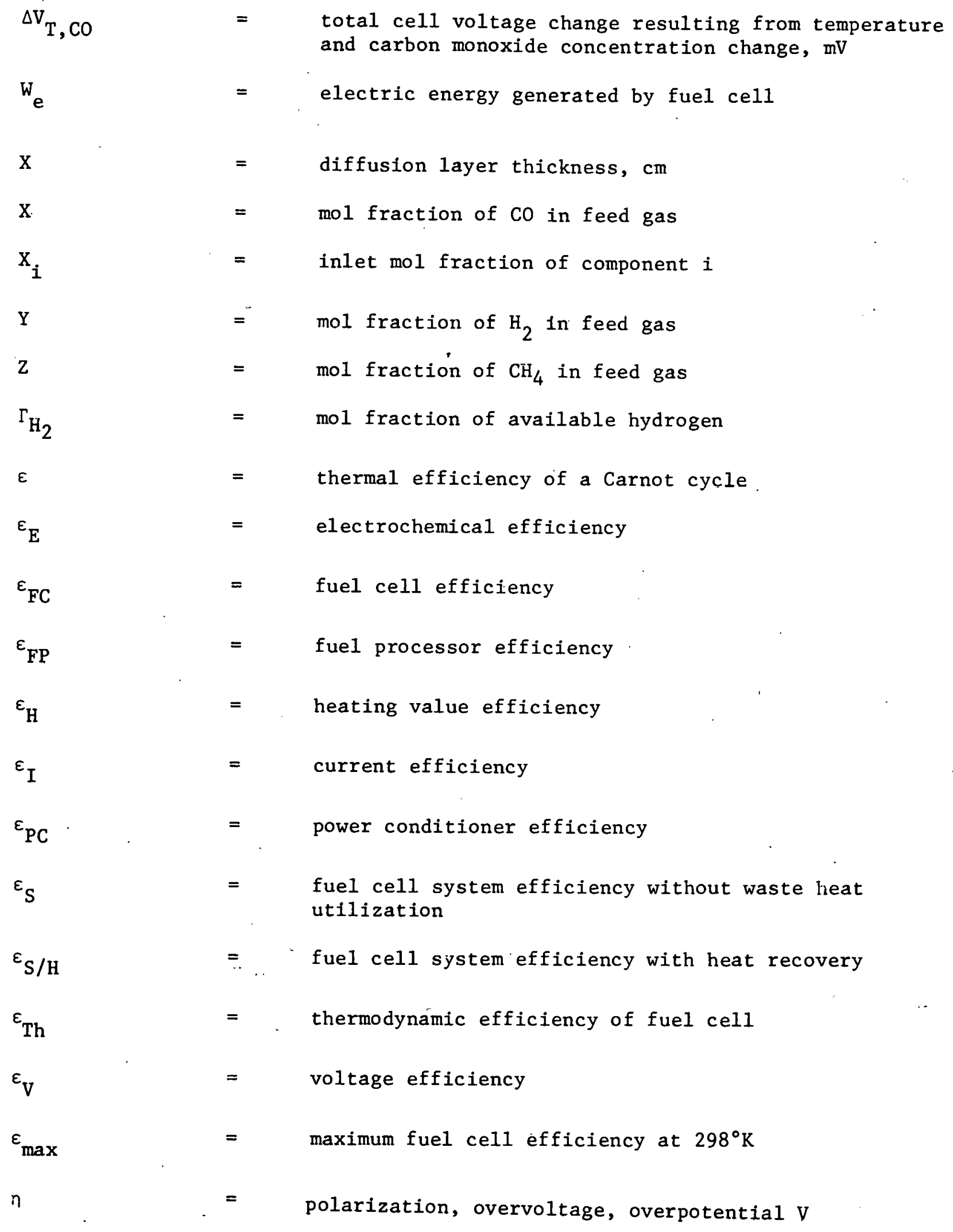




\begin{tabular}{|c|c|c|}
\hline$\eta_{\text {act }}^{\prime}$ & $=$ & activation polarization, $\mathrm{V}$ \\
\hline$n_{\text {conc }}$ & $=$ & concentration polarization, $V$ \\
\hline$n_{e}$ & $=$ & electrodé polarization, $\mathrm{V}$ \\
\hline nohm & $=$ & ohmic or resistance polarization, \\
\hline
\end{tabular}

